\title{
Psychological profiles and behavioural characteristics in chromosomal syndromes
}

Citation for published version (APA):

Borghgraef, M. M. C. (1991). Psychological profiles and behavioural characteristics in chromosomal syndromes. [Doctoral Thesis, Maastricht University]. Maastricht University. https://doi.org/10.26481/dis.19910613mb

Document status and date:

Published: 01/01/1991

DOI:

10.26481/dis.19910613mb

Document Version:

Publisher's PDF, also known as Version of record

\section{Please check the document version of this publication:}

- A submitted manuscript is the version of the article upon submission and before peer-review. There can be important differences between the submitted version and the official published version of record.

People interested in the research are advised to contact the author for the final version of the publication, or visit the DOI to the publisher's website.

- The final author version and the galley proof are versions of the publication after peer review.

- The final published version features the final layout of the paper including the volume, issue and page numbers.

Link to publication

\footnotetext{
General rights rights.

- You may freely distribute the URL identifying the publication in the public portal. please follow below link for the End User Agreement:

www.umlib.nl/taverne-license

Take down policy

If you believe that this document breaches copyright please contact us at:

repository@maastrichtuniversity.nl

providing details and we will investigate your claim.
}

Copyright and moral rights for the publications made accessible in the public portal are retained by the authors and/or other copyright owners and it is a condition of accessing publications that users recognise and abide by the legal requirements associated with these

- Users may download and print one copy of any publication from the public portal for the purpose of private study or research.

- You may not further distribute the material or use it for any profit-making activity or commercial gain

If the publication is distributed under the terms of Article $25 \mathrm{fa}$ of the Dutch Copyright Act, indicated by the "Taverne" license above, 


\title{
PSYCHOLOGICAL PROFILES AND BEHAVIOURAL CHARACTERISTICS IN CHROMOSOMAL SYNDROMES
}

\author{
Proefschrift
}

ter verkrijging van de graad van doctor aan de Rijksuniversiteit Limburg te Maastricht, op gezag van de Rector Magnificus, Prof. Mr. M.J. Cohen, volgens het besluit van het College van Dekanen, in het openbaar te verdedigen op donderdag, 13 juni 1991 om 16.00 uur

door

Martine Marie Collette Borghgraef 
Promotoren

Prof. dr. J.P.M. Geraedts

Prof. dr. J.P. Frijns

Beoordelingscommissie

Prof. dr. R.H. Kuijten, voorzitter

Prof. dr. J.C.B. Bremer

Prof. dr. J. de Haan

Dr. H. Veenema

Prof. dr. H. Van der Vlugt

Dit proefschrift is voornamelijk gebaseerd op onderzoek dat werd gefinanclerd door het Fonds Koningin Fabiola en het Steunfonds Marguerite-Marie Delacrolx (Tienen). 


\section{CONTENTS}

INTRODUCTION

1. Mental Retardation: History and late Definitions

2. The Diagnostic Criteria for Mental Retardation and 10 Classification System of the American Psychiatric Association (DSM III-R, 1987)

3. Causes of Mental Retardation

a. Incidence/ Prevalence

b. Biological Causes of Mental Retardation

4. Mental Retardation of Genetic Origin: Towards a

Delineation of Characteristic Psychological Profiles ?

5. Outline of the Present Study

1. Introduction: $X$-linked Mental Retardation

2. The Fraglle $X$ Syndrome: a Study of the Psychological Profile.

a. Fragile $X$ syndrome: a study of the psychological profile in 23 prepubertal patients. Borghgraef $M$., Fryns J.P., Dielkens A., Pyck K., Van den Berghe $H_{\text {. }}$ Clin. Genet. 32, 179-186, 1987.

b. The postpubertal fra $(X)$ male: a study of the intelligence and the psychological profile of $17 \mathrm{fra}(X)$ boys. Borghgraef M., Fryns J.P., Van den Bergh R., Pyck K., Van den Berghe $\mathrm{H}$. Proceedings of the IASSMD 8th World-Congress. Key Issues in Mental Retardation Research. Dublin, Ireland, August 21-25, 1988 (Revised version).

c. Intelligence and cognitive profile in the $\mathrm{fra}(X)$

syndrome: a longitudinal study in $18 \mathrm{fra}(X)$ boys.

Curfs L.M.G., Schreppers-Tijdink G., Wiegers A. Borghgraef M., Fryns J.P. J. Med. Genet. 26, 443-446, 1989.

d. Strengths and weaknesses in the cognitive profile of fra $(\mathbf{X})$ patients. Curfs L.M.G., Borghgraef M., Wiegers A., Schreppers-Tljdink G.A.J., Fryns J.P. Clin. Genet., $36,405-410,1989$. 
6. Relationship between age and IO among fragile $X$ males: multicenter study. Fisch G.S., Arinami T.,Froster-Iskenius U., Fryns J.P. Borghgraef M., Howard-Peebles P.N., Schartz C.E., Simensen R.J., Shapiro L.R. Am.J. Med. Genet. 38, 481-487, 1991.

f. The temale and the fragile $X$ syndrome. Data on clinical and psychological findings in 7 fra $(X)$ carriers. Borghgraef M., Fryns J.P., Van den Berghe $H$. Clin. Genet., 37, 341-346, 1990.

3. Conclusion X-linked Mental Retardation

1. Introduction 95

2. The 49, XXXXY Syndrome. 97

a. The $49, X \times X X Y$ syndrome. Clinical and psychological 97 lollow-up data. Borghgraef M., Fryns J.P., Smeets E., Marien J., Van den Berghe H. Clin. Genet. 33, 429-434, 1988.

b. The $49, X X X X Y$ syndrome. Clinical and psychological findings In 5 patients. Curts L., Schreppers-Tijding G., Wiegers A., Borghgraef M., Fryns J.P. J. Ment. Def. Res., 34, 277-282, 1990.

3. The 48, XXYY Syndrome. Follow-up data on clinical characteristics and psychological findings in 4 patients. Borghgraef M., Fryns J.P., Van den Berghe H. Genet. Couns., 1991 (in press)

4. The female with quadruplo- $X$ syndrome: Clinical and psychological findings in three prepubertal girls.

Borghgraef M., Fryns J.P., Van den Berghe H. Clin. Genet., 1991 (in press).

5. Discussion and Conclusion

B. Autosomal Syndromes

1. Introduction

2. Psychological profile and behavioural characteristics in 12 patients with Prader-Willi syndrome. Borghgraef $M$., Fryns J.P. Van den Berghe $H$. Genet. Couns., 38, 141-150, 1990. 
3. Clinical and poychological findings in three young children with full or partial trisomy of chromosome 8. Borghgraef M., Fryns J.P. Tijdschr. Orthoped. Kinderpsych. 12, 9-22, 1987.

4. Psychological findings in three children with ring $\mathbf{1 5}$ chromosome. Borghgraef M., Fryns J.P., Van den Berghe H. J. Ment. Def. Res. 32, 337-347, 1988.

5. Discussion and Conclusions

GENERAL CONCLUSION, AND PERSPECTIVES FOR THE FUTURE

APPENDIX: Materials and Methods

SUMMARY

SAMENVATTING 

INTRODUCTION 



\section{MENTAL RETARDATION: HISTORY AND LATE DEFINITIONS}

Mental deficiency came into the attention of the scientific world in the beginning of the 19th century and, since then, a variety of definitions of the phenomenon "mental retardation" have been proposed, depending on the personal view and the scientific interest and background of the different authors.

The first systematic description of mental deficiency dates from the early 19 th century and was published by a group of french psychiatrists (see Kanner, 1976). Persons with a disorder of the intellectual functions were grouped as "idiotic" and first defined by Ph. Pinel (1745-1826) as:

"L"idiotisme est l'abolition plus ou moins absolue soit des fonctions de l'entendement, soit des affections du coeur". Esquinol (1772-1840) accentuated the incurableness of idiocy: "L'idiotie n'est pas une maladie, c'est un état dans lequel les facultés intellectuelles ne se sont jamais manifestées, ou n'ont pas pu se développer". The organic base of the mental disorder was added by Belhomme (1800-1873): "L"idiotie est un état constitutionel".

In the early 20th century (1907) the british psychiatrist Tredgold formulated a new definition in which the social adaptation became the principal criterion in the diagnosis of mental deficiency: "Mental deficiency is a state of incomplete mental development of such a kind and degree that the individual is incapable of adapting himself to the normal environment". From the interest for feeble-minded and mentally retarded in France standardized tests of intelligence were developed. This psychometric approach did not directly contribute to a change in the definition of mental deficiency but had a progressively increasing contribution in the ascertainment of the mentally deficient.

Binet was the first french author to develop such a test of intelligence in 1905 viz. "L'échelle métrique pour la mesure de l'intelligence" (Kanner, 1976). Later on Stern (Kanner, 1976) connected to this tool the idea of "intelligence-quotient" (IQ).

A lot of criticism on these approaches was raised, especially by E.A. Doll (1941) in his outpaint of the "inclusive concept" of mental deficiency wherein the social maladaptation was accentuated: "Mental deficiency is a state of social incompetence obtaining at maturity, resulting from developmental arrest of constitutional origin; this condition is essentially incurable".

These six criteria were considered to be essential in the diagnosis of a person as mental deficient. 
These "traditional" definitions, were based on the concept that the mental deficlent is a sick person, incurable, imperfect and defective, and resulted in overprotection and underestimation.

After World War II there was an important evolution in the view of the mentally retarded. He was considered as a person, fully member of the community and someone with (limited) learning possibilities. Schools, day centres and sheltered workshops were built. Hope and positive expectations arose.

The American Association on Mental Deficiency (AAMD) proposed in 1959 a new definition and denomination viz. "mental retardation". The last, revised version of the Manual on Terminology and Classification in Mental Retardation, edited by Grossman in 1983, was "Mental retardation refers to significantly subaverage general intellectual functioning existing concurrently with deficits in adaptive behaviour, and manifested during the developmental period". A reduced intellectual functioning and deficit in adaptive behaviour were the two principal criteria. This definition was in accordance with the description of mental retardation in the International Classification of Diseases, 9th revision of the World Health Organzation (1978) and the Diagnostic Classification of the American Psychiatric Association (DSM III-R, 1987).

\section{THE DIAGNOSTIC CRITERIA FOR MENTAL RETARDATION AND CLASSIFICATION SYSTEM OF THE AMERICAN PSYCHIATRIC ASSOCIATION (DSM III-R, 1987)}

\section{“1. MENTAL RETARDATION}

a. The essential features of this disorder are: (1) significantly subaverage general intellectual functioning, accompanied by (2) significant deficits or impairments in adaptive functioning, with (3) onset before the age of 18. The diagnosis is made regardless the presence or absence of a coexisting physical or other mental disorder.

General intellectual functioning. General intellectual functioning is defined as an intelligence quotient (IQ or IQ equivalent) obtained by assessment with one or more of the individually administered general intelligence tests (e.g., Wechsler Intelligence Scale for Children - Revised, Stanford Binet, Kaufman Assessment Battery for Children). Significantly subaverage intellectual functioning is defined as an IQ of 70 or below on 
an individually administered IQ test. Since any measurement is failible, an $I Q$ score is generally thought to involve an error of measurement of approximately five points; hence, an IQ of 70 is considered to represent a band or zone of 65 to 75 .

Treating the IQ with some flexibility permits inclusion in the Mental Retardation category of people with IQs somewhat higher than 70 who exhibit significant deficits in adaptive behavior. It also allows exclusion of those with IQs somewhat lower than 70 if the clinical judgement reveals no significant deficits or impairments in adaptive functioning. An $\| Q$ level of 70 was chosen because most people with IQs below 70 require special services and care, particularly during the school-age years.

Adaptive functioning. Adaptive functioning refers to the person's effectiveness in areas such as social skills, communication and daily living skills, and how well the person meets the standards of personal independence and social responsibility expected for his or her age by his or her cultural group. Adaptive functioning in people with Mental Retardation (and in people without Mental Retardation) is influenced by personality characteristics, motivation, education, and social and vocational opportunities. Adaptive behaviour is more likely to improve with remedial efforts than is $I Q$, which tends to remain more stable. Useful scales have been designed to quantify adaptive functioning or behavior (e.g., the Vineland Adaptive Behavior Scales, American Association of Mental Deficiency Adlaptive Behavior Scale). Idealy, these scales should be used in conjunction with a clinical judgment of general adaptation. If these scales are not available, clinical judgment of general adaptation alone, the person's age and cultural background may be sufficient.

Age at onset. By definition, Mental Retardation requires onset before age 18. If a similar clinical picture develops for the first after the age of 18 , the syndrome is a Dementia, not Mental Retardation, and is coded within the Organic Mental Disorders section of the classification. An example: a 19-year-old with previously normal intelligence who developed the clinical picture of Mental Retardation after sustaining brain damage in an automobile accident. Dementia, however, can be superimposed on previously existing Mental Retardation. An example: a mildly mentally retarded child whose functioning deteriorated after sustaining brain damage in an automobile accident. If the clinical picture develops before the age of 18 in a person with previously normal intelligence, Mental Retardation and Dementia should both be diagnosed. 
Differential diagnosis. The diagnosis of Mental Retardation should be made when the criteria are met, regardless of the presence of another diagnosis: In Specific Developmental Disorders (unassociated with Mental Retardation) there is a delay or failure of development in a specific area, such as reading or language, but in other areas the child is developing normally. In contrast, a child with Mental Retardation always has general developmental dellay in many areas.

In Pervasive Developmental disorders there is qualitative impairment in the development of reciprocal social interaction, of verbal and nonverbal communication skills, and of imaginative activity. These abnormalities are not normal for any stage of development, whereas in Mental Retardation (unassociated with another disorder) there are generalized delays in development, but the person behaves as if he or she were passing through an eartler normal developmental stage.

Mental retardation may, however, coexist with Specific Developmental Disorders (e.g., a severe language deficit out of proportion to other areas of development in a person with Mild Mental Retardation). People with a Pervasive Developmental Disorder also frequently have Mental Retardation.

The code Borderline Intellectual Functioning is given when there is borderline intellectual functioning, which generally is in the IQ range of 71 to 84 , and the diagnosis of Mental Retardation is not warranted. Differentiating Mild Mental Retardation from Borderline Intellectual functioning requires careful consideration of all avaible information, including psychological test scores.

b. A practical mode of CLASSIFICATION is provided by the determination of the degree of intellectual deficiency.

The classiciation proposed by the DSM-III-R (1987) is according to the severity of the symptoms.

There are four degrees of severity, reflecting the degree of intellectual impairment, and based on the standard score obtained by the individual on a rellable test of intelligence, such as the Terman or WECHSLERscales (Table 1)." 
Table 1

\begin{tabular}{ll}
\hline Degree of severity & $\mathbb{I Q}$ \\
\hline & \\
mild & $50-55$ to \pm 70 \\
moderate & $35-40$ to $50-55$ \\
severe & $20-25$ to $35-40$ \\
profound & below 20 or 25 \\
\hline
\end{tabular}

This system became widely used and, in fact, became the standard classification system. An IQ of 70 has gained considerable popularity as a cut off score for the retarded group. In Belgium and the Netherlands this cut off score was put on IQ 80 in the practice of ascertaining mental retarded people because in these countries children with an IQ between 70 and 80 mostly fulfill all conditions of the clinical description of mental retardation (Dumont 1971, Hellinckx 1973). Critics of IQ classifications have deplored the fact that IQs are sometimes substantially affected by nonintellectual factors such as language handicaps and emotional barriers, and that individual IQs sometimes change markedly over time. Realistically, however, classifications according to 10 , serve a positive function if they take account of other aspects of behaviour.

\section{CAUSES OF MENTAL RETARDATION}

\section{a. INCIDENCE / PREVALENCE}

In industrialized countries 2 to $3 \%$ of the general population is believed to be mentally retarded.

One would expect approximately $2.5 \%$ of a population to attain IQs 2 standard deviations or more below the mean, but empirical studles find closer to $3 \%$ of IQs to be below 70 . Moreover, a significant number of individuals present IQs below 30. This excess at the lower end of the Gauss distribution illustrates that intelligence in some individuals is reduced by the action of a single or a small number of pathological blological factors.

The prevalence of Mental Retardation is influenced by a great number of environmental factors such as community, age, social and ethnic background, geographic region and sex. 
Almost all studies dealing with mental retardation in children report a higher incidence in males than in females (1.5:1). Social integration of a moderately mentally retardated will be more difficult in a competitive industrialized community than in a rural environment. The severely retarded are mostly identified before the age of one year, especially in the presence of physical abnormalities.

\section{b. BIOLOGICAL CAUSES OF MENTAL RETARDATION}

It is clear that deficits in intelligence can be caused by a great diversity of conditions. Although medical science has made tremendous progress in identifying these conditions, the cause of the mental impairment remains still obscure in a large number of patients. Frequently a distinction is made between two broad categories of mentally retarded people. One group consists of those persons for whom there is evidence of organic abnormalities resulting in diminished mental abilities. This group is called the organically retarded. The second group consists of individuals without apparent biological or medical cause for their diminished mental abilities. They are sometimes referred to as the culturally retarded, the familially retarded, or the functionally retarded (Ingalls, 1978).

Most individuals who are functionally retarded manifest only mild mental retardation, and most come from low-social class families, whereas the organically retarded tend to be more severely impaired, and are almost equally distributed over all social classes.

We adopted the classification system proposed by the AAMD (Grossman, 1977). It divides the mentally retarded into nine broad categories based on the etiology (cause) of the retardation, with a tenth category "other".

Table 2. Major causal categories of mental retardation

1. Infections and intoxications

2. Trauma or phystcal agerits

3. Disorders of metabolism or nutrition

4. Gross brain disease (postnatal)

5. Unknown prenatal influences

6. Chromosoma ll abnormalitty

7. Gestational disorders

8. Retardation following psychiatric disorders

9. Retardation due to environmental influences 
An increase of the medicall interest in the mentally retarded has been noted since the early sixties, and was mainly stimulated by a progressive better understanding of biological mechanisms, involved in the causation of mental retardation. Several factors have stimulated this increased interest in research in mental retardation. Among them, the most important seem to be:

1. The development of clinical cytogenetics and the discovery of an increasing number of autosomal and sex chromosomal anomalies. With the introduction of different chromosome banding techniques in 1970, the number of constitutional chromosomal syndromes increased to more than 120.

2. The discovery that $X$-linked mental retardation is, after 21 trisomy, the most common cause of mental retardation in males. Particular interest has been devoted to the medical and psychologicall aspects of the fra $(X)$ syndrome, which accounts for 40 to $50 \%$ of all patients with X-linked mental retardation (Lubs, 1969; Sutherland, 1977; Fryns, 1984; Hagerman, 1983).

3. The establishment of genetic counseling services in University Hospitals and Centres of Human Genetics. In these clinics, individuals, couples and families confronted with the occurrence of mental retardation in their children or relatives seek genetic counseling. A precise etiological diagnosis in the mentally retarded is a conditio sine qua non for accurate genetic counseling, and this has forced clinical genetics towards the study of mental handicap.

4. The delineation of an increasing number of socalled multiple malformation-mental retardation syndromes (MCA-MR) has raised the interest of the dysmorphologist in mental retardation. Moreover, a great number of these syndromes has been found to be due to small autosomal deletions and rearrangements.

\section{MENTAL RETARDATION OF GENETIC ORIGIN: TOWARDS A DELINEATION OF CHARACTERISTIC PSYCHOLOGICAL PROFILES?}

Fourty-five to fifty percent of the mentally retarded manifest behavioural and/or emotional problems, and these constitute one of the major problems for their social adaptation and integration (Ineichen, 1984). Psychiatric syndromes occur more frequently in this population than in general population. Since a few years there is an increasing interest in the question whether mental retardation of constitutional genetic origin (e.g. 
chromosomal syndromes) is characterized by specific profiles of cognitive development, learning disabilities and/or behavioural disorders.

As already stated in the previous paragraph, after the introduction to the different chromosomal banding techniques more than 120 different numerical and structural chromosomal anomalies were delineated as clinically recognizable entities on the basis of the presence of specific dysmorfic symptoms. In fact, each syndrome contains a whole spectrum of physical, cognitive and behavioural characteristics.

Research was devoted to the exact description of the cytogenetic abnormalities and to the delineation of the associated dysmorfic symptoms. The primary aim has been to delineate new genetic entities in mental retardation, using the simple tools of the clinical geneticist: diagnostic skills and clinical experience plus some routine technical investigations. Up to now, however, almost no studies involved the kind of mental retardation, the changes with age, the behavioural characteristics and emotional development in mentally retarded patients, whereas overall it is clear that psychiatric disturbances are a major problem in mentally retarded patients. The study of the psychological profile of children with a precise etiology of mental retardation may lead to the identification of distinct subtypes of learning disabilities and may help to elucidate the role of the chromosomes and their genes in normal cognitive development. The study of a possible relationship between psychopathological abnormalities and chromosomal syndromes is particularly fascinating. There are a number of major issues and problems relevant to the relationship between behavioural problems and emotional disturbances and mental retardation of genetic origin.

Another important plea for the study of the psychological profile of mentally retarded children is the importance of early diagnosis of the cause of the psychomotor delay of a child for the prevention of mental retardation, and includes family investigation and genetic counseling of the parents.

Therefore, it is important to define the physical and psychological features in all these conditions as exactly as possible at a very early age.

A multidisciplinary approach and research in this area is urgently needed as it is very important in early diagnosis, genetic counseling and elaboration of education programs.

Clearness about the etiology and information about the prognosis of the child reduces stress, anxiety and tension in the family. Parents get a more realistic image of the future and a better opinion of the capacities of their child.

Finally, a better knowledge and understanding of the developmental problems in children with different chromosomal syndromes will offer more complete information and better possibilities of guidance to the parents, teachers and therapists and gives optimal chances for the upgrowing child. 
Management and educational therapies have to be elaborated based on a precise knowledge and insight in the demands and needs of the child with this specific syndrome.

\section{OUTLINE OF THE PRESENT STUDY}

In this thesis we present our experience of psychological testing and behavioural observations in children with different types of chromosomal syndromes.

Part $I$ is devoted to the fra $(X)$ syndrome. After definition and delineation of the concept "fra $(X)$ syndrome" in a historical perspective, we present psychodiagnostic data in prepubertal fra $(X)$ boys, postpubertal fra $(X)$ males and $\operatorname{fra}(X)$ female carriers, and give special attention to the strengths and weaknesses in their cognitive profile. In addition, we discuss the longitudinal IQ findings of a multicenter study. In this study the relationship between age and IQ among fra $(X)$ males was examined by the study of 101 $\mathrm{fra}(\mathrm{X})$ males from 6 centres.

In part II we describe and delineate the psychological profile of children with different sex-chromosomal abnormalities and autosomal syndromes i.e. 8 boys with $49, X X X X Y$ syndrome, 4 boys with $48, X X Y Y$ syndrome, 3 girls with $48, X X X X$ karyotype, 12 Prader-Willi syndrome patients, 3 girls with ring chromosome 15 syndrome and 3 children with trisomy 8 . These data are compared and confronted with the available data of the literature.

In the third part we formulate concluding remarks and perspectives for the future.

\section{References}

American Psychiatric Association: Diagnostic and Statistical Manual of Mental Disorders, 3rd edition, revised. Washington, DC, American Psychiatric Association. 1987.

Doll E.A.: The essentials of an inclusive concept on mental deficiency. Am.

J. Ment. Def. 46:214-219, 1941. 
Dumont J.J.: Leerstoornissen. Rotterdam, Lemniscaat. 1971. 304 pp. Grossman H.J. (Ed.): Manual on Terminology and Classification in Mental retardation, 1977 revision. Washington D.C., AAMD, 1977, XIII, 172 pp. Hellinckx: Sociale Vaardigheild voor Geestelijk Gehandicapten. Rotterdam, Lemniscaat, $1973,237 \mathrm{pp}$.

Ingalls R.P.: Cases of mental handicap. Chapter III in: Mental Retardation. The Changing Outlook. New York, Wiley and Sons. 1978. pp 103-138. Kanner L.: Geschiedenis van de Zwakzinnigenzorg en van het

Zwakzinnigenonderwijs (Dutch translation of: A History of the Care and Study of the Mentally Retarded, 1964, by D.A. van Knevelen). Lochem, De Tijdstroom. 1976. $122 \mathrm{pp}$.

World Health Organization: International Classification of Diseases, 9th revision. Clinical Modification. Vol. 2. An Arbor, Michigan, Edwards Brothers Inc. 1978. 


PART I. THE FRAGILE X $(F R A(X))$ SYNDROME 



\section{INTRODUCTION: X-LINKED MENTAL RETARDATION}

Scientific interest in mental retardation has been late in coming.

Over the past 30 years the professional world and the community at large have become increasingly interested in the various aspects and problems associated with mental retardation. Physicians, at one time only consulting to treat such manifestations as convulsions etc. purely symptomatic, now manifest a profound interest in the etiology of the conditions and in the ways of preventing them, and devote most of their professional time to the patients and their famillies. In addition to IQ testing and evaluation psychologists and orthopedagogists now tackle behavloural problems and psychological disturbances with special programmes. Physiotheraplsts help in improving motor development and functional rehabilitation. Other specially adapted programmes are conducted by other speclalized professionals such as speech therapists, social workers, educators and nursing staff.

The reason for this dramatic reversal of the previously existing situation in just a few years are probably manyfold. It is clear, however, that by far the most powerful impetus has come from the results of genetic investigations. In 1959, it was discovered that the condition which to everybody, from scientist to layman was the symbol for a mental retardation syndrome, namely mongolism, was due to a chromosomal anomaly. More recently, in the 1970's, a numerically equally important type of mental retardation, had been gradually emerging: the fra $(X)$ syndrome. This condition, which apparently also underlies some cases of autism, and also frequently found in socalled culturally retarded, is due to one single mutant gene located on the X-chromosome (for technical aspects see infra*).

The Leuven Center for Human Genetics contributed largely to the delineation of the "classical" phenotype of males with fra $(X)$ syndrome, as that of a moderately retarded adult male with large testes and typical long face. This picture is present in more than $60 \%$ of the adult males, but is much less typical in the prepubertal boy. In the first years of life most boys clinically present an overgrowth syndrome with macrocephaly, large fontanel and body proportions exceeding the 97th percentlle for age. Between the age of 2 and 12 years behavioural characteristics dominate the picture. Almost all boys in that age range present a severe attention deficit, hyperkinetic behaviour and autistic features which progressively disappears after puberty.

We examined up to now more than 180 familles with 1,2 or more affected 
fragile $X$-males. From the beginning of the study it became evident that a more concise description of the psychological profile in young fra $(X)$ positive boys was a conditio sine qua non towards early diagnosis of this condition.

This part of the thesis summarizes the expertise which has been built up in the past few years on the psychological profile of the fra $(X)$ syndrome, studies at different ages and at regular intervals in the male patients. The final paper reports on the psychosocial behavioural profile in the fra $(X)$ positive female carrier female. Up to now, borderline to subnormal mental development was documented in more than $30 \%$ of female carriers but little was known about the associated behavioural problems. Carefull observation and study of their psychological profile disclosed symptoms and signs highly comparable with those in affected males, and equally progressively disappearing and regressing with age.

"Technical note (seo also Appendix)

Investigations for fragile $X$ (fra $(X))$.

The following indications for the fra $(X)$ syndrome investigation were taken into account:

1) Familial mental retardation with borderline to mentally subnormal mother and multiple mentally retarcled sibs, males and females.

2) males of families with suspicion of X-linked mental retardation on the basis of family data with extensive pedigree analysis

3) Instifutionallized mentally retarded males and young males with developmental disability and hyperkinetic and/or autistlo behaviour without gross dysmorphic or neurological symptoms.

In all patients tra $(X)$ screening was performed in at least 100 unbanded metaphases of folic acid deprlved cultures, and the presence of a fra $(X)$ chromosome was confirmed with $G$ - and P-banding (see figs 2 and 4, pp. 205-206 in appendix). In female carriers BrdU incorporation was used for the study of $X$-chromosome inactivation and for confirmation of the fragile $X-C$ sitte to be at Xq27-28, especially in low percentages of fra $X$ females. 
2. THE FRAGILE $X$ SYNDROME: A STUDY OF THE PSYCHOLOGICAL PROFILE

2a. FRAGILE X SYNDROME: A STUDY OF THE PSYCHOLOGICAL PROFILE IN 23 PREPUBERTAL PATIENTS 



\title{
Fragile $(X)$ syndrome: a study of the psychological profile in 23 prepubertal patients
}

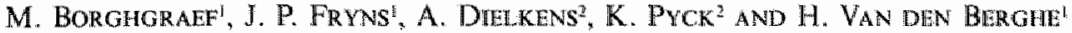 \\ 'Centre for Human Genetics and 'Department of Children's Psychiatry, University of Leuven, \\ Belgium
}

\begin{abstract}
In this study a further analysis of the psychological profile in the prepubertal fragile (X) $(\mathrm{fra}(\mathrm{X}))$ male was performed. The results of the psycho-diagnostic examination of 23 fra(X) boys were compared to a control group of 17 males of the same age with "non-specific" mental retardation. A number of important quantitative and qualitative difrerences were observed between the two groups. In the preschool age group the majority of fra $(\mathrm{X})$ boys was mildly mentally retarded. In the school-age group, however, most boys were moderately to severely mentally retarded. This indication of a decline in intellectual performance with age in the $\mathrm{fra}(\mathrm{X})$ syndrome was confirmed by a longitudinal individual follow-up of seven fra(X) boys in this age group. In contrast to intellectual performance, appearance of the attention deficit disorder (or hyperkinesis), with its attendent overactivity and impulsiveness, decreases with age, and is independent of the intellectual level. Autistic behaviour was more frequently observed in the youngest $\mathrm{fra}(\mathrm{X})$ males, and was more pronounced in the moderately mentally retarded. In more than $50 \%$ of the boys of preschool age the association of hyperkinesis and autistic features was found. Language and speech development in the fra $(X)$ syndrome is both symptomatic and specific. Beside a severe, global speech retardation, there are some distinct speech characteristics in the young fra(X) males such as rapid speech rhythm, speecli impulsiveness and perseverative speech.
\end{abstract}

Received I December 1986, accepted for publicarion 14 May 1997

Key words: $X$-linked retardation; fra $(X)$ syndrome; mental retardation; psychological testing.

At the present time, the mar $(X)$ syndrome has become the subject of increasing and widespread medical interest (Sutherland 1979, Sutherland \& Ashforth 1979, Herbst 1980, Herbst \& Miller 1980, Jacobs et al. 1980, Mattei et al. 1981, Blomquist et al. 1982, Carpenter et al. 1982, Carpenter 1983, Fishburn et al. 1983, Glover 1983, HowardPeebles 1983, Jacobs et al. 1983, BrøndumNielsen et al. 1983, Fryns 1984).

The second International Workshop on the fragile $(X)(f r a(X))$ and $X$-linked mental retardation was convened by Dr. Gillian
Turner and resulted in the publication of a special volume of the American Journal of Medical Genetics on the different aspects of this particular form of X-linked mental retardation (Opitz 1986). The $\mathrm{fra}(\mathrm{X})$ syndrome has generally been recognized as one of the major causes of mental retardation in all populations, ethnic groups and races. Venter \& Op't Hof (1982) indicate that the incidence of fra(X) syndrome in children of school age is 1 to $1360-1500$ for boys and 1 in 2073 for girls. A typical clinical triad consisting of moderate mental retardation, 
long face and large ears, and macro-orchidism, is found in up to two-thirds of the adult male patients. In the prepubertal male, however, the phenotype is much less suggestive, and clinical diagnosis is much more difficult. Recent studies indicate that the psychological profile of young $\mathrm{fra}(\mathrm{X})$ males may be much more specific than the clinical spectrum. Hyperkinetic behaviour and autistic features have been documented in several previous studies (Jacobs \& Fryns 1983, Fryns 1984, Hagerman 1983, Levitas et al. 1983a, Levitas et al. 1.983b, Newell et al. 1983, Largo \& Schinzel 1985).

The aim of this study was to further delineate the specific developmental and behavioural characteristics in the prepubertal $\mathrm{fra}(\mathrm{X})$ positive males and to correlate these findings with age and intellectual level. Finally, the data were compared with the findings in a group of male children of the same age with 'non-specific' mental retardation.

\section{Material and Methods}

23 prepubertal boys, 10 in the preschool age group ( 2 years 5 months -6 years 9 months) and 13 between the ages of 7 years and 1.1 years 9 months were investigated. In all patients the diagnosis of $\mathrm{fra}(\mathrm{X})$ syndrome was confirmed using standard cytogenetic techniques with standard M199 lymphocyte cultures and screening of 100 cells for
Xq27.3 fragilities (Fryns 1984). In this study we included all young $\mathrm{fra}(\mathrm{X})$ males who were diagnosed in this center in the age groups indicated above.

The results of the psychological and developmental testing were compared with the findings in a group of 17 males of the same age ( 6 between 3 years 6 months and 6 years 11 months and 11 between 7 years 4 months and 12 years) with "non-specific" mental retardation and negative $\operatorname{fra}(\mathrm{X})$ screening. Extensive etiological-diagnostic evaluation in these boys failed to reveal a specific diagnosis. The intellectual level and the socio-economic origin of both groups of patients were as identical as possible.

In general, Wechsler scales (WPPSI (Hobby 1976, Stinissen \& Vander Steene 1981) and WISC-R (Van Haasen et al. 1985)) were used as intelligence tests. $\mathrm{Pa}$ tients with severe verbal disability were evaluated with a performance intelligence test, SON 21-7 (Snijders \& Snijders-Oomen 1975). In the youngest males and in the severely mentally retarded, observation and measurement were done with the BOS 2-30 developmental scale (Van der Meulen \& Smrkovsky 1983) completed with items of the Stutsman intelligence test (Smulders 1981). IQ distributions are indicated in Table 1.

The verbal developmental level was tested with the Reymell developmental language

\section{Table 1}

Proportional distribution of both groups of patients in relation to age and intellectual level

\begin{tabular}{|c|c|c|c|c|c|c|c|c|}
\hline \multirow{4}{*}{$\begin{array}{l}\text { Intellectual level } \\
\text { (10 distribution) }\end{array}$} & \multicolumn{4}{|c|}{ Fra $(x)$ boys } & \multicolumn{4}{|c|}{ "Non-specific" mental retardation } \\
\hline & \multicolumn{2}{|c|}{$<7$ year's } & \multicolumn{2}{|c|}{$7-12$ years } & \multicolumn{2}{|c|}{$<7$ years } & \multicolumn{2}{|c|}{$7-12$ years } \\
\hline & & Mean & & Mean & & Mean & & Mean \\
\hline & no. & 10 & no. & 10 & no. & 10 & no. & 10 \\
\hline Slight (52-68) & 7 & 67 & 4 & 56 & 3 & 67 & 5 & 63 \\
\hline Moderate $(36-51)$ & 3 & 46 & 9 & 42 & 3 & 42 & 6 & 41 \\
\hline Total & 10 & 56 & 13 & 47 & 6 & 52 & 11 & 52 \\
\hline $\begin{array}{l}\text { Fisherr's exact } \\
\text { probability test: }\end{array}$ & \multicolumn{4}{|c|}{ Prob: 0.099} & \multicolumn{4}{|c|}{ Prob: 1.0000} \\
\hline
\end{tabular}


scales (Reynell 1977), and passive and active verbal levels were evaluated separately. For boys with better verbal functioning the UTANT test (Kohnstamm et al. 1971) was chosen. Additional data on speech and verbal development were obtained after completion of questionnaires by the parents, speech therapists and teachers.

Specific attention and interest were given to two behavioural characteristics that were found to be the most typical in young $\mathrm{fra}(\mathrm{X})$ boys in previous studies, i.e. hyperkinetic and autistic behaviour. Diagnostic evalluation of these behavioural problems were made and the clinical observation data were scored on objective scales. The attention deficit disorder was evaluated with the observation lists for the evaluation of children with possible minimal brain dysfunction (Department of Children's Psychiatry, University of Leuven) and the autistiform behaviour with the Autiscale (Van BerckelaerOnnes \& Snijders-Oomen 1981), respectively.

\section{Results}

Intelligence (Table I)

In the "non-specific" mental retardation group $50 \%$ of the boys were mildly mentally retarded, and $50 \%$ were moderately mentally retarded in both age groups. The $1 \mathrm{Q}$ level in the $\mathrm{fra}(\mathrm{X})$ boys varied much more with age. In the preschool age group $70 \%$ of the fra $(\mathrm{X})$ boys were mildly mentally retarded and in $30 \%$ mental retardation was moderate. In contrast, in the age group 7 years -11 years 9 months, $30 \%$ were mildly mentally retarded and $70 \%$ moderately mentally retarded.

This decline of IQ with age was confirmed by the individual observation and testing of seven $\mathrm{fra}(X)$ boys at different ages (Fig. 1): in two of them, mildly mentally retarded at the preschool age, the IQ score decreased 10 and 12 units during the school
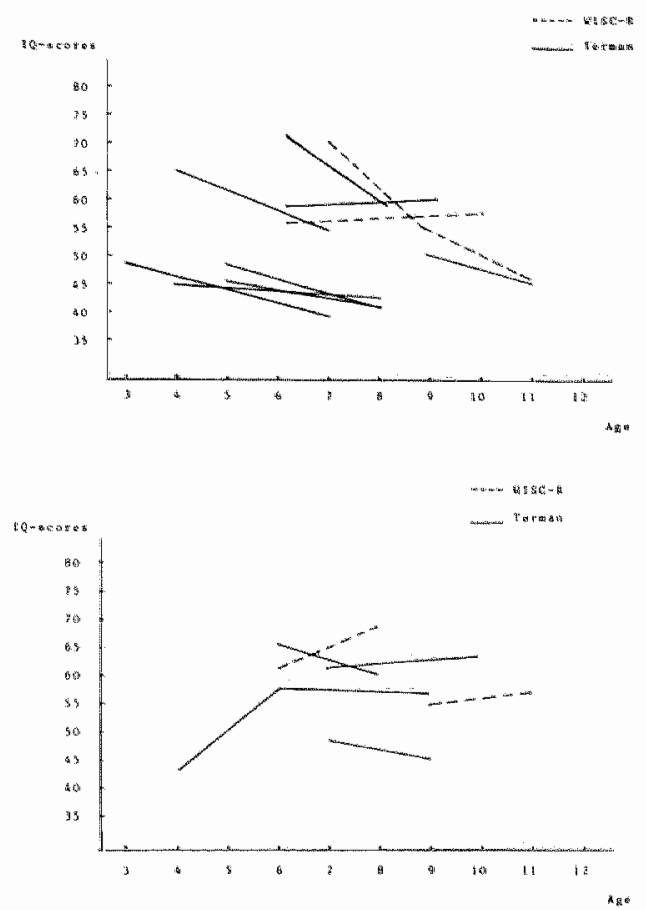

Fig. 1. a. $1 Q$ progression over time in 7 fra $(x)$ boys. $1 \mathrm{Q}$ was measured with the WISC or Terman. b. 10 progression over time in 6 boys with "mon-specific" mental retardation. 10 was measured with the WISC or Terman.

age period. In one other boy the regression was even more pronounced, progressing from borderline intelligence to moderate mental retardation. In the group of children with 'non-specific' mental retardation, the IQ levels 17uctuated much less with age.

Subtest analysis of the results of the Wechsler scale testings (Hobby 1976, Stinissen \& Vander Steene 1981, Van Haasen et al. 1985) in the mildly mentally retarded fra(X) boys showed a specific decline in the subtests 'digit span" and "coding', which both evaluate attention and concentration. Better results were obtained in the subtests "block design" and "object assembly", both evaluating visual-spatial perception and synthesis-analysis. In the moderately mentally retarded fra( $\mathrm{X})$ boys and the control 
Table 2

Distribution of the attention deficit disorder $(A D D)$ in both groups in relation to age and intellectual level

\begin{tabular}{|c|c|c|c|c|c|c|c|c|c|c|}
\hline \multirow[b]{3}{*}{ Intellectual level } & \multicolumn{5}{|c|}{ Fral $(X)$ boys with ADD } & \multicolumn{4}{|c|}{$\begin{array}{l}\text { Boys with non-sipecific mental } \\
\text { with } A D D\end{array}$} & \multirow{3}{*}{$\begin{array}{c}\text { etardation } \\
\text { Total } \\
\text { no. }\end{array}$} \\
\hline & \multicolumn{2}{|c|}{$<7$ years } & \multicolumn{2}{|c|}{$7-12$ years } & \multirow{2}{*}{$\begin{array}{c}\text { Total } \\
\text { no. }\end{array}$} & \multicolumn{2}{|c|}{$<7$ years } & \multicolumn{2}{|c|}{$7-12$ years } & \\
\hline & no. & $\%$ & no. & $\%$ & & no. & $\%$ & no. & $\%$ & \\
\hline Slight & $6 / 7$ & 80 & $2 / 4$ & 50 & $8 / 1$ & $2 / 3$ & 33 & $0 / 5$ & 0 & $2 / 8$ \\
\hline Moderate & $2 / 3$ & 66 & $5 / 9$ & 55 & $\pi / 12$ & $1 / 3$ & 33 & $3 / 6$ & 50 & $4 / 9$ \\
\hline Total & $8 / 10$ & 80 & $7 / 13$ & 54 & $15 / 23$ & $3 / 6$ & 50 & $3 / 11$ & 27 & $6 / 17$ \\
\hline \multirow{2}{*}{$\begin{array}{l}\text { Fisher's exact } \\
\text { probability test: }\end{array}$} & \multicolumn{5}{|c|}{ Prob: 0.1319} & \multicolumn{5}{|c|}{ Frob: 0.4000} \\
\hline & \multicolumn{10}{|c|}{ Prob. (total fra $(X)$ - total control): 0.1089} \\
\hline
\end{tabular}

group of 'non-specific' mental retardation these differences were not observed.

\section{Speech and Language Development}

In all $\mathrm{fra}(\mathrm{X})$ boys speech and language development was retarded. In the preschool age group no major differences were observed between the fra $(X)$ boys and the control group. The language developmental level of the mildly mentally retarded was 2 years 8 months in both groups. In the moderately mentally retarded the language developmental level was 2 years 2 months in the $f r a(X)$ group and 2 years 6 months in the control group.

In the age group 7 years - 11 years 9 months, in addition to a severe retardation in speech development (mean level of 4 years 3 months in the mildly mentally retarded $\mathrm{fra}(\mathrm{X})$ group, compared to 5 years in the control group), we observed characteristic disturbances in speech development of the $\operatorname{fra}(\mathrm{X})$ boys, non-related to their IQ level.

The most distinct findings were: rapid speech rhythm $(85 \%)$, verbal unstructuredness $(83 \%)$, speech impulsiveness $(62 \%)$ and perseverative speech $(62 \%)$. Two to three word sentences were exclusively observed in the moderately mentally retarded $\mathrm{fra}(\mathrm{X})$ boys. In addition, in the fra $(X)$ syn- drome a deficit in attention and memory function was observed in both age groups.

\section{Attention Deficit Disorder}

Collection and analysis of all data on behaviour, obtained from school, from the family and from individual observation in all boys, indicated that in both age groups the attention deficit disorder was twice as common in fra(X) syndrome compared to the control group.

A total of $80 \%$ of the young fra $(X)$ boys and $54 \%$ of the school age fra $(X)$ boys presented attention deficit disorder, compared to $50 \%$ of the boys of the control group at preschool age and $27 \%$ of the older control groups (Table 2).

Moreover, in the fra $(X)$ boys hyperkinetic behaviour was found to be age dependent; hyperkinesis was more frequent and intense in the preschool age group, and was equally present in the mildly and the moderately mentally retarded. In the control group, attention deficit disorder was only noted in the moderately mentally retarded at school age.

Finally, the different symptom categories of hyperkinesis were separately evaluated; in the category "attention disorder", the $\mathrm{fra}(\mathrm{X})$ boys displayed a "low task pressure" and "incapacity to finish tasks". "Clumsi- 
Table 3

The association of fra( $(\mathrm{X})$-autistiform behaviour in relation to age and intellectual level

\begin{tabular}{|c|c|c|c|c|c|c|}
\hline \multirow[b]{2}{*}{ Intellectual lewel } & \multicolumn{5}{|c|}{ Fra $(x)$ boys with autistic behaviour } & \multirow{2}{*}{$\begin{array}{c}\text { Boys with 'mon-sipecific' mental re } \\
\text { tardation with autistic behaviour } \\
\text { Total } \\
\text { no. }\end{array}$} \\
\hline & no. & $\mathscr{H}$ & no. & $\%$ & $\begin{array}{c}\text { Total } \\
\text { no. }\end{array}$ & \\
\hline Slight & $2 / 7$ & 20 & $0 / 4$ & 0 & $2 \times 11$ & 0.8 \\
\hline Moderate & $3 / 3$ & 30 & $4 / 9$ & $3 \pi$ & $7 / 12$ & 011 \\
\hline Total & $5 / 10$ & 50 & $4 / 13$ & $3 n$ & $9 / 23$ & al17 \\
\hline $\begin{array}{l}\text { Fisher's exact } \\
\text { probability test: }\end{array}$ & \multicolumn{4}{|c|}{ Prob: 0.4444} & \multicolumn{2}{|r|}{ Prob: 0.0187} \\
\hline
\end{tabular}

ness" and "coordination difficulties", a symptom of movement disorders, were other characteristic findings in the mildly mentally retarded fra $(X)$ boys. Finally, "low frustration tolerance" and "verbal unstructuredness", as an indication of learning deficit, are much more pronounced in the fra(X) group versus control group.

\section{Autistiform Behaviour}

The association "mental handicap - autistic features" could be demonstrated in $39 \%$ of the fra(X) boys. Contrary to hyperkinesis, the autistic behaviour was more pronounced in the moderately mentally retarded fra $(X)$ boys. Furthermore, the autistic features diminished with age (Table 3). In the preschool age group, they were present in $50 \%$ of the boys, but at school age in only $31 \%$ of them. In comparison with the control group, the fra( $X)$ boys presented a distinct relational disturbance with aversion of physical contact and fugitive eye contact. A strong reaction to minor changes was more frequently observed in the youngest fra(X) boys. Motor disturbances with intermittent Muttering and stereotypy were observed in the two age groups. Echolalia was not found to be of diagnostic relevance. In contrast, perseverative speech was 2.5 times more frequent in the preschool fra(X) boys, and was not related to their intellectual level.

\section{Discussion}

Previous studies of the fra( $X)$ syndrome have shown that fra( $X)$ screening is indicated in all boys with 'essential" mental retordation (Hagerman 1983, Fryns 1983, Fryns \& Van den Berghe 1984). Clinical stigmata are absent in at least $50 \%$ of the prepubertal fra( $X)$ boys, and so selection of patients for fra $(X)$ screening on a clinical basis is inefficient.

Recent studies of prepubertal fra(X) males have suggested a distinct pattern of characteristic and universal developmental and behaviounal disturbances in the fra $(X)$ syndrome (Fryns et al. 1984, Hagminan 1983, Largo \& Schinzel 1985, Levilas et al. 1983a, Levitas et al. 1983b, Newell et al. 1983).

A better description and delineation of the psychological characteristics in the pre pubertal fra(X) boys may lead to better selection criteria for $\operatorname{fra}(X)$ screening in young boys with essential developmental delay. The aim of the present study was a further delineation of the psychological profile of young fra( $\mathrm{X}$ ) boys. Therefore $\mathrm{x}$ tensive psycho-diagnostic examinations were performed in 23 frat $(X)$ boys, and the results were compared to an essential group of 17 males of the same age with nonspecific" mental retardation. Literature data on intellectual development of fra $(X)$ males 
all indicate that the majority of $\mathrm{fra}(\mathrm{X}) \mathrm{pa}$ tients are moderately to severely mentally retarded. A small percentage of males is found both in the profound mentally retarded and in the borderline to mildly mentally retarded (Carpenter et al. 1982 , Carpenter 1983, Hagerman et al. 1983 and 1985 . Fryns \& Van den Berghe 1984, Largo \& Schinzel 1985, Levitas et al. 1983b, Mattei et al. 1983, Partington 1984).

A second important finding in most studies is the evolution of the intellectual performance of $\mathrm{ra}(\mathrm{X})$ males with age; in the majority of young fra $(X)$ males borderline to slight mental handicap was noted, whereas moderate to severe mental retardation was found in most fra $(X)$ adult males ( $\mathrm{Ha}$ german et al. 1983, Largo \& Schinzel 1985 , Levitas et al. 1983b, Partington 1984, Rhoads 1984). This is confirmed in the present study: $70 \%$ of the fra $(X)$ boys in the preschool age group were mildly mentally retarded compared to only $30 \%$ in the school-age group. This decline in intellectual performance was also confirmed by a longitudinal, long-term follow-up of six patients reported in the literature (Partington 1984, Rhoads 1984) and of seven boys in this study. These findings seem to indicate a possible deterioration of the mental performance in fra $(X)$ males with age, but further longitudinal studies are needed to confirm these important primary findings.

In contrast to intellectual performance, behavioural disturbances decrease with age: the most striking of them, hyperkinesis or attention deficit disorder, is the most evident in young, preschool fra $(X)$ boys. Overactivity, deficits in coordination and concentration, and impulsiveness, all typical hyperkinesis symptoms, are less or more present in fra $(X)$ boys (Hagerman et al. 1983. Fryns et al. 1984, Levitas et al. 1983b. Mattei et al. 1981).

In the present study a severe attention deficit disorder was evident in $80 \%$ of the preschool fra $(\mathrm{X})$ males, and in $50 \%$ of the school-age group. Hyperkinetic behaviour is not only more frequent, but also more intense in the preschool age group, and is independent of the intellectual level, in contrast with the findings in the males with 'non-specific' mental retardation, in whom hyperkinesis is much more pronounced in the moderately mentally retarded.

The evaluation of autistiform characteristics revealed autistic symptoms in $39 \%$ of the young $f r a(X)$ males. We observed the same autistic features as reported by Levitas et al. (1983a, 1983b) i.e. aversion of physical contact, fugitive eye contact, strong reaction to minor changes, stereotypy and repetitive behaviour. Autistic behaviour was more frequently observed in the youngest $\mathrm{fra}(\mathrm{X})$ males, and was more pronounced in the moderately mentally retarded.

Language and speech development in the fra $(X)$ syndrome is both symptomatic and specific. In addition to a severe, global retardation, speech development in young $\mathrm{fra}(\mathrm{X})$ males presents a number of distinct characteristics which are not related to the intellectual level: rapid speech rhythm, speech impulsiveness, verbal unstructuredness and perseverative speech. In contrast with the literature data (Levitas et al. 1983b, Newell et al. 1983) short (2-3 word) sentences were exclusively observed in the moderately mentally retarded and not in the mildly mentally retarded fra $(X)$ males. Echolalia, frequentlly indicated as characteristic in the $\mathrm{fra}(\mathrm{X})$ syndrome (Fryns et al. 1984. Largo \& Schinzel 1985, Levitas et al. 1983a and 1983b, Newell et al. 1983) was not found to be of diagnostic relevance in the present study. It was observed in $18 \%$ of the $\operatorname{fra}(\mathrm{X})$ males and in $31 \%$ of the control group patients. As already reported (Fryns et al. 1984) stuttering was not observed more frequently in the $\mathrm{fra}(\mathrm{X})$ boys compared to the controls.

The present study on the psychological 
profile of the prepubertal fra $(\mathrm{X})$ confirms that, despite interindividual differences, a distinct and typical pattern of developmental and behavioural problems and difficultles can be delineated in the $\mathrm{fra}(X)$ syndrome.

In more than $50 \%$ of the boys of the preschool-age group the typical association of hyperkinesis and autistic behaviour was found. This association was not present in the control group of boys with 'non-specific' mental retardation. Prepubertal fra(X) boys in the school-age period are differentiated from the control group boys mostly by specific language and speech developmental problems as well as verbal unstructuredness, rapid speech rhythm and perseverative speech. Autistic and hyperkinetic behaviour are much less pronounced in that age group, although fluttering and some repulse of physical contact still persist at that age. Further studies are needed to establish whether the typical psychological findings are exclusively found in the fra $(X)$ syndrome, or may also be present in other forms of 'non-specific' mental retardation.

Nevertheless, the better knowledge and understanding of these psychological findings are of increasing importance in the early recognition and diagnosis of the fra $(X)$ syndrome.

\section{Reflerences}

Blomquist, H. K. K. H. Gustavson, G. Holmgren, I. Nordenson \& A. Sweins (1982). Fragile site $X$ chromosome and $X$-linked menlal retardation in Northern Swedish county. A. prewalence study. Clin. Genet. 21, 209..214.

Brendum-Nielsen. K., H. V. Dyggve, H. Knudsen \& J. Olsen (1983). A chromosomal survey of an institution for mentally retarded. Dan. Med. Bull. 30, 5-13.

Carpenter, N. J. (1983). The fragile $X$ chromosome and its clinical manifestation. In Cytogenetics of the Mammalian X Chromosome, part B. New York, Alan R. Liss, pp. 399-414.
Carpenter, N. J, L. G. Leichtmarn \& B. Say (1982). Fragile X-linked mental retardation. A survey of 65 patients with mentall retardation of unknown origin. Am. J. Dis. Child. 136, $392-398$.

Fishburn, J., G. Turner, A. Daniel \& R. Brookwell (1983). The diagnosis and frequency of X-linked conditions in a cohort of moderately retarded males with affected brothers. Am. J. Med. Genet. 14, 713-724.

Fryns, J. P. (1983). X-gebonden mentale retarda. tie en fragiel $X$-chromosoom. Tijdschr. Geneeskd. 39, 1247-1249.

Fryns, J. P. (1984). "The fragile $X$ syndrome. A study of 83 families. Clin. Genet. 26, 497-528.

Fryns, J. P., J. Jacobs, A. Kleczkowska H. Van den Berghe (1984). The psychological profile of the rragile X syndrome. Clin. Genet. 25, $131-134$.

Fryns, J. P. \& H. Van den Berghe (1984). X-linked mental retardation and fragile $(\mathrm{Xq} 27)$ site. In Aspects of Human Genefics. Basel, Karger, pp. 33-39.

Glover, T. (1983). The fragile $X$ chromosome: factors influencing its expression in vitro. In Cytogenetics of the Mammalian Chromosome. Part B. New York, Alan R. Liss pp. 415-430. Hagerman, R. M. Kemper \& M. Hudson (1985). Learning disabilities and attentional problems in boys with the fragile $X$ syndrome. $A m . d$. Dis. Child. 139,674-678.

Hagerman, R, A. C. M. Smith \& R. Mariner (1983). Climical features of the fragile $X$ syndrome. In The Fragile $X$ Syndrome. Diagnosis. Biochemistry and Inrerewton. R. Jenssen-Ha german \& P. McKenzie-McBogg (eds.). DillonColorado, Spectra Publishing Pp. 17-53

Herbst, D. S. (1980). Nonspecific X-linked mental retardation. 1. A review with information from 24 new families. Am. J. Med. Genet. 7, 443-460.

Herbs1. D. S. J. R. Miller (1980). Nonspecific $X$-linked mental retardation. II. The frequency in British Columbia. Am. J. Med. Genet. 7, $461-469$.

Hobby, K. L. (1976). W.P.P.S.I. profile form. Amsterdam, Lisse, Swets \& Zeitlinger, pp. 15.

Howard-Peebles, P. N. (1983). Conditions aflecting fragile $X$ chromosome structure in witro. In Cyogenetics of the Mammatian $X$ Chromosome, part B. New York, Alan R. Liss, pp. $431-443$.

Jacobs, J. \& J. P. Fryns (1983). Psychologísche aspecten van het fragiel $X$-syndroom. Tidschr. Orthoped. Kinderpsych. 7. 172-182.

Jacobs, P. A., T. W. GHover, M. Mayer, P. Fox I. W. Gerrand, H. G. Dunn \& D. S. Herbsi (1980). 
$X$-linked mental retardation a study of 7 famil iess. An. J. Med. Genel. 7, 471-489.

Kohnstamm, G. A., A. P. Messer \& A. K. De Vries (1971). De Uirechtse adalnivan Test wor 4-7 jarigen. Ansterdam, 3 wets \& Zietlinger, pp. 5.

Largo, R. H. \& A. Selhnzel (1985). Dewelopmental and behavioral disturbances in 13 boys with fragile $X$ syndrome. Eur. J. Pediar. 143, $269-275$

Levitas, A. R. J. Hageman, M. Braden, B. Rimbaud, P. MeBogg \& 1. Matus (1983a). Autisn and the fragile $X$ syndrome. $J$. Dev. Behav. Pediatr. 4, 151-158.

Levitas, A., P. McBogg \& R. Hagerman (1983b). Behavioral dysfunction in the fragile $X$ syndrome. In The Fragile $X$ Syndrome. Diagnosis. Biochemistry and Jinervention. R. JenssenHagerman \& P. McKenzic-McBogg (eds.). Dillon-Colorado, Spectra Publishing, pp. 153173.

Mattei, J. F., M. G. Mattei, C. Aumeras, M. Auger \& F. Giraud (1981). X-linked mental retardation with the fragile $X$. A study of 15 families. Hum. Genet. 59, 28\-289.

Newell, K., B. Sanborn \& R. Hagerman (1983). Speech and language dysfunction in the fragile $\mathrm{X}$ syndrome. In The Fragile X Syndrame. Diagnosis, Biochemistry and Intervention. $\mathrm{R}$. Jenssen-Hagerman \& P. McKenzie-McBogg (eds.). Dillon-Colorado, Spectra Publishing, pp. 175-200.

Opitz, J. M. (ed.) (1986). X-Linked mental retardation 2. Am. J. Med. Genet. 23(1/2), Spec. Issuo.

Partington, M. W. (1984). The fragile X syndrome II: preliminary data on growth and development in males. Am. J. Med. Genet. 17, 175-194.

Reynell, I. (1977). Reynell Denelopmenial Language Stales (revised). Windsor, Berks, N.F.E.R.

Rhoads, F. A. (1984), Fragile $X$ syndrome in Hawaii: a summary of clinical experience. $A m$. d. Med. Genet. 17. 209-214.

Sinulders, F. J. M. (1981). Stutsmant Intelligent- etest Voor Kleuters. Nijmegen. The Netherlands, Berkhout.

Snijders, J. Th. \& N. Snijders-Oomen (1975). Snijders-Oomen Nigtierbale Intelligentieschaal. S.O.N. 21-7. Groningen, The Netherlands, Tjeenk Willink.

Stinissen, J. \& G. Vander Steene (1981). WPPS.1.: Wechsler Preschool and Primary Scale of Intelligence. Handleiding bij de Vlaamsie aanpassing. Amsterdam, Lisse, Swets \& Zeitlinger, p. 158 .

Sutherland, G. (1979). Heritable fragile sites on human chromosomes. III. Detection of fra(X)(q27) in males with X-linked mental retardation and in their female relatives. Hum. Genet. 53, 23-27.

Suthertand, G. R. \& P. L. C. Ashforth (1979). Xlinked mental retardation with macroorchidism and the fragile site at $\mathrm{Xq} 27$ or 28 . Hum. Genet. 48, 117-120.

Van Berckelaer-Onnes, I. A., F. J. H. Harinck \& M. Smit (1981). Awti-schaal. Ten behoeve wan de onderkenning wan vroegkinderlijk autiswe. Amsterdam, Lisse, Swets \& Zeitlinger, p. 24.

Van der Meulen, B. F \& M. Smrkovsky (1983). Baylen Onwikkelingsschalen. BOS 2-30. Handleiding. Amsterdam, Lisse, Swets \& Zeitlinger, pp. 183.

Van Haasen, P. et al. (1985). Wechster Intelligence Scale for Children. Revised. Nederlandstalige Uitgave. Hondleiding voor Instructies en Scaring. Amsterdam, Lisse, Swets \& Zeillinger.

Venter, P. A., J. Op't Hor (1982). Cytogenetic abnormalities including the marker $X$ chromosome in palients with severe mental retardation. S. African Med. J. 62, 947-950.

Address:

J. P. Firyls

Centre for Hwman Generios

U.Z. Gasthuisberg

Herestraat 49

B-3000 Leuven

Belgitum 
2b. THE POSTPUBERTAL FRA $(X)$ MALE: A STUDY OF THE PSYCHOLOGICAL PROFILE OF 17 FRA $(X)$ BOYS 

Proceedings of the IASSMD 8th World-Congress. Key Issues in Mental Retardation Research. Dublin, Ireland, August 21-25, 1988 (Revised version).

\section{THE POSTPUBERTAL FRA $(X)$ MALE $A$ study of the intelligence and the psychological profile of 17 fra $(X)$ boys}

\section{BORGHGRAEF ${ }^{1}$, J.P. FRYNS', R. VAN DEN BERGH ${ }^{2}, K^{\prime}$. PYCK ${ }^{2}$, H. VAN DEN BERGHE'}

${ }^{1}$ Centre for Human Genetics and ${ }^{2}$ Children's Psychiatry, University of Leuven, U.Z. Gasthuisberg, Herestraat 49, B-3000 Leuven, Belgilum

\section{SUMMARY}

In this paper we present the results of a psychological study performed in 17 postpubertal fra $(X)$ boys, and compare the results with the findings in a control group of $12 \mathrm{fra}(X)$ negative boys of the same age and the same IQ level. An important finding is the clear shifting towards a lower level of intellectual functioning in the postpubertal $f r a(X)$ positive males compared to the prepubertal group. In the analysis of the cognitive functions we found a specific decline in school achievement, short term memory and abstraction; better results were obtained for sequential thinking and visuospatial perception. In $70 \%$ of the fra $(X)$ boys verbal IQ was higher than performance IQ, but this was also found in the control group. In addition to a global language retardation, more pronounced than in the control group, fra $(X)$ boys presented characteristic speech disturbances like rapid speech rythm, stuttering and echolalia.

Attention Deficit Hyperkinetic Disorder (ADHD) was twice as common in fra $(X)$ compared to the control group. The ADHD decreases with age in contrast with the autistic behaviour which shows only a mild drop with age. The social functioning in the fra $(X)$ boys was slightly lower than the controll group, but their adaptive behaviour was better than expected from their intelligence level. 


\section{INTRODUCTION}

In the past few years increasing interest was given to the psychological profile of fra $(X)$ males, especially to their intellectual development (for review, see Veenema et al., 1987). Some studies suggested specific patterns of developmental and behavioural problems i.e. autistic features and hyperkinetic behavlour also called Attention Deficit Hyperkinetic Disorder (ADHD) (for review, see Borghgraef et al, 1987).

In a previous study (Borghgraef et al., 1987) (see pp 25-34) we investigated the intellectual level, speech and language development and the presence of $A D H D$ and autism of 23 prepubertal fra $(X)$ boys. This study confirmed that, in comparison to a control group of boys of the same age and of the same IQ with a non-specific type of mental retardation, a distinct pattern of cognitive and emotlonal dysfunctions can be demonstrated in the fra $(X)$ syndrome. In addition, some of these behavioural patterns were found to be clearly age-dependent. The aim of the present study was to examine a groujp of postpubertal $f r a(X)$ boys (ages between 15 and 22 years) with the help of the same parameters and the same criteria as defined in the previous study.

\section{MATERIAL AND METHODS}

\section{Subjects}

17 postpubertal fra $(X)$ positive boys between the age of 15 and 22 years, were investigated. In all patients the diagnosis of fra(X) syndrome was confirmed using standard cytogenetic techniques with M199 lymphocyte cultures and screening of 100 cells for the presence of an Xq27.3 fragility (Fryns, 1984).

The results were compared to the findings in $12 \mathrm{fra}(X)$ negative boys of the same age with 'nonspecific mental retardation'. The intellectual level, and the socio-economic origin of both groups of patients were matched as much as possible.

\section{Method}

As a general rule we used as intelligence test the Wechsler scales (WPPSI, WISC, WAIS) and/or the Terman test (Terman \& Merrill, 1973; Wechsler, 1974; Stinissen and Vander Steene, 1981; Van Haasen et al, 1985). In 
severely mentally retarded males observation and measurement with the BOS-2-30 and the SON were done (Snijders \& Snijders-Oomen, 1975; Van der Meulen and Smrkovsky, 1983). The verbal developmental level was tested with the Reynell scales, and the UTANT test was used for boys with better verbal functioning (Kohnstamm et al., 1971; Reynell, 1977).

Diagnostic evaluation of the behavioural problems was made by clinical abservation with objective scales. The Attention Deficit Hyperkinetic Disorder was evaluated with the Observation list for the evaluation of children with possible Minimal Brain Defect (MBD) (Department of Children's Psychiatry, University of Leuven), and the autistiform behaviour with the Auti-scale (Van Berckelaer-Onnes et al., 1981).

Finally, we used the PAC1 and 2 (Günzburg scale) (Günzburg, 1977) to evalutate the abilities in social functioning and independence.

\section{RESULTS}

\section{General, clinical data}

In table 1 and 2, we summarized the most important personal and clinical data of the $17 \mathrm{fra}(X)$ boys and the 12 control boys.

The mean age at diagnosis was 14 years, and the mean percentage of positive fra( $X)$ cells was $18 \%$.

In eleven boys psychomotor retardation was noted by the parents before the age of one year.

Eight parents mentioned already some hyperkinetic behaviour in their young child, and two others observed autistic features at the same period of age.

\section{Intelligence}

The IQ levels in the fra $(X)$ boys were widespread, but the majority had a moderate to severe mental retardation (see Table 3). Two boys were mildly mentally retarded, 5 were moderately retarded, 7 were severely and 3 profoundly mentally retarded. The mean IQ of the fra $(X)$ boys was 34.4 , and the mean mental age was about 5 years.

As a control group we selected 12 boys with non-specific mental retardation of the same age and with the same $I Q$ distribution as the fra(X) 
positive boys.

We were able to collect longltudinal follow-up data on IQ-testing of $11 \mathrm{fra}(X)$ boys and 9 boys of the control group at different ages. Fig. 1 and 2 give a survey of the 10 fluctuations with age in the 11 fra $(X)$ boys and the 9 control boys. An explictt falling line with a strong correlation between $1 Q$ and age was found in the fra $(X)$ group. In the control group IQ levels were much more stable with age (see Fig. 3).

In all boys with mild mental retardation at young age a significant deciline of IQ was noted. Fifty $\%$ of the fra $(X)$ boys, who had a moderate mental retardation at early age were severely mentally retarded at adult age, compared to twenty $\%$ of the boys of the control group.

In both groups the IQ proflle showed an obvlous dysharmony : $70 \%$ of the boys of both groups have a better verbal IQ than performance IQ.

Subtest analysis of the results of Wechsler and Terman scale testings shows a specific decline for the subtests (arithmetic, digit span, similarlties and object assembly) which evaluate respectively school achievement, memory and abstraction faculty. Better results were obtained for the subtests 'block design' and 'plcture-arrangement' evaluating sequential thinking and visuospatial perception.

\section{Speech and language development}

Speech and language development were delayed in all boys. The language developmental level of the fra $(X)$ boys was 5 years, compared to 6 years in the control group. In general the language performances were found to be strongly dependent of the IQ-level. The language-age level of the severely retarded fra $(X)$ boys was 3yrs $7 \mathrm{~m}$, and the age-level of the moderately and mildly retarded fra $(X)$ boys was $5 y r s ~ 11 \mathrm{~m}$.

The results on the Reynell test showed a difference of one year between the level of understanding (receptlve language) and the level of expressive language in both groups.

The results on the UTANT test showed a relatively good performance on vocabulary and description-abllity, and very poor results on analogies/opposition subtest and grammar, compared to the control group. Characteristic disturbances in the fra $(X)$ group were echolalia and stereotyped speech as well as a more rapid speech rythm and stuttering. Table 4 summarizes the precize data of both groups. 


\section{Hyperkinesls (Attention Deficit Hyperkinetic Disorder (ADHD))}

Analysis of all collected data on behaviour, obtained from Individual observations of parents, teachers and therapists, indicated that the ADHD was twice as common in fra $(X)$ syndrome, compared to the control group. A hyperkinetic behavlour was present in $29 \%$ of fra $(X)$ versus $16 \%$ of the control group (see Table 5).

Moreover, this ADHD was found to be related to the Intellectual level in both groups : the most severe hyperkinetic behaviour was seen in the severely to profoundly retarded. The different symptom categorles of the ADHD were separately evaluated : poor attention and concentration, extreme hyperactlity and impulsivity were the most evident in the fra $(X)$ group (see Flg. 4).

\section{Autlistiform behaviour}

The assoclation "mental retardation-autistic behaviour" was present in $4 / 17$ of the fra $X$ boys, compared to $1 / 12$ of the control group.

As in the hyperkinetic syndrome, the autistic behaviour fluctuated with the intelligence level and was most pronounced in the severely and profoundly retarded fra $(X)$ boys (see Table 6).

Analysing the different symptom categories of the Auti-scale (see Fig. 5), the fra $(X)$ boys presented distinct motor and sensittve troubles like fluttering, stereotyples of movements and hypersensitivity to noises. Relational problems and echolalia were also more frequent in fra(X).

\section{Social functions}

Soclal performance of the fra $(X)$ patlents was lower than of the boys of the control group. The mean percent of acquired skills was $42 \%$ for the fra $(X)$ group and $55 \%$ for the control group and was not age dependent but strongly correlated with the intelligence level.

In the analysis of the different categories of the PAC (Günzburg. 1977) we observed a specific decline for "sociallzation" (play function and dally domestic affairs) in the severely and profoundly retarded, and a decilne for "communication" (school achlevement) in the moderate and mildly retarded (see Table 7). 


\section{DISCUSSION}

Previous studies on fra $(X)$ males have suggested a distinct pattern of characteristic and universal developmental and behavioural disturbances (for review see Veenema et al, $1987 \mathrm{a}$ and b) The aim of the present study was to better delineate and describe the psychological profile and development of patients with fra $(X)$ syndrome.

In a previous study, we performed extensive psychodiagnostic examinations in 23 pre-pubertal fra $(X)$ boys, aged between 2 years and 12 years and observed a distinct and typical pattern of developmental and behavloural problems in fra $(X)$ boys. We also found strong evidence for age-dependence of IQ level and behaviour characteristics (Borghgraef et al., 1987) (see pp 25-34).

After these findings we decided to study a group of 17 pubertal and young adult fra $(X)$ patients with the same parameters and criteria and with special attention for the fluctuation of the intellectual level over age and with a detailed outline of social functioning. The results were also compared to a group of 12 males of the same age and IQ with 'nonspecific' mental retardation.

Reviewing the literature data on intelligence in the $\mathrm{fra}(\mathrm{X})$ syndrome, we found a strong agreement in the different studies: most of them indicate that the majority of fra $(X)$ patients, mostly adults, are moderately to severely mentally retarded (Theobald et al, 1987; Bregman et al, 1987; Rochi et al, 1987; Veenema et al, 1987). In the present study of 17 pubertal fra $(X)$ patients, $29 \%$ were moderately mentally retarded and $41 \%$ severely retarded. A smaller number was found in the profoundly retarded $(18 \%)$ and in the mildly retarded $(12 \%)$ group.

Another important finding in most studies is the negative correlation between age and level of intellectual functioning. Hagerman et al (1983) and Paul and Leckman (1984) noted a progress in intellectual performances in childhood, followed by a plateau and finally a drop during puberty. Lachiewicz et all (1987) examined retrospective data and observed a negative correlation between IQ and age with a decline during middle childhood years. Partington et al (1984) and Theobald et al (1987) did not find a significant decline of intelligence level with age and asserted that the majority of fra $(X)$ boys present a non-progressive moderate to severe mental retardation from birth on.

Comparing the results of the present study with the data on the prepubertal fra $(X)$ boys of the previous study, a clear shifting towards a lower level of 
intellectual functioning is noted. $47 \%$ of the young fra $(X)$ boys were mildly mentally retarded compared to only $11 \%$ of the postpubertal group.

The present data seem to confirm the hypothesis of a decline in intelligence performances with age. We attempted to confirm this finding by a longitudinal , longterm follow-up of $11 \mathrm{fra}(X)$ boys, and compared these data with follow-up findings in 9 boys of the control group. In both groups a strong correlation was found between $\mathrm{IQ}$ and age, with a distinct drop of the intellectual performance with age in the fra $(X)$ boys: all mildly mentally retarded fra $(X)$ males dropped to the level of moderate retardation and 50 $\%$ of the moderately mentally retarded became severely retarded. As Lackiewicz et al (1987) we have no arguments to explain this intellectual decline by a deterioration or loss of acquired abilitles. Their cognitive functioning is improving with age. A more evident explanation is that fra $(X)$ boys learn at a slower rate than expected from their initial IQ level. This decline might be induced by the behavioural problems with poor attention and social disability and a poor stimulating environment.

In the analysis of the cognitive profile by subtest examination of the Wechsler scale testings, the $\mathrm{fra}(X)$ boys of this study showed a specific decline in arithmetics, digit span, object assembly and similarities, which evaluate school achievement, short term memory and abstraction faculty. Compared to the control group, better results were obtained for block design and picture arrangement which evaluate sequential thinking and visuospatial perception.

In $70 \%$ of the fra $(X)$ boys of the present study verbal IQ was higher than performance IQ. This dysharmonic profile was also observed in several other studies (for review see Rochi et al, 1987). Chudley et al (1983), in contrast, noted higher performance than verbal IQ in fra $(X)$ boys).

We noted the same difference with higher verbal IQ than performance IQ also in the control group, indicating that this finding is not a specific characteristic of the fra $(X)$ syndrome.

Further evaluation of the speech and language development showed in general a lower developmental level in $\mathrm{fra}(X)$ boys : they scored at a 5 year age level, compared to a 6 year age level in the control group. In both groups the language performances were strongly dependent of IQ level. In addition to the global language retardation, $f r a(X)$ boys presented some very characteristic speech disturbances like rapid speech rythm and stuttering. The most distinct findings were the presence of echolalia and stereotyped speech, and those were noted by Rhea et al (1987), Levitas et al (1983a) and Newell et al (1983), Hagerman et al (1985).

Echolalia and sturtering were not so frequently observed in the prepubertal 
fra $(X)$ boys (Borghgraef et al, 1987) (pp 25-34) and seemed to be a characteristic finding at postpubertal age.

The Attention Deficit Hyperkinetic Disorder was twice as common in fra $(X)$ boys $(29 \%)$ compared to the control group (16\%). In our experience, poor attention and concentration, extreme hyperactivity and impulsivity are the most obvious behavioural symptoms in the fra $(X)$ syndrome. Furthermore this behavioural disorder seems to be strongly age-dependent. In previous studles we concluded aiready that behaviour problems decrease with age (Borghgraef et $\mathrm{al}_{i 1}$ 1987). This is confirmed in this study for the ADHD : 67 $\%$ of the prepubertal boys present hyperkinesls, compared to $29 \%$ of the older boys. This age-dependence is not so evident for the autistic behavioural characteristics, which show a smaller drop with age: $23 \%$ of the postpubertal fra $(X)$ boys still present autistic features, versus $39 \%$ in the prepubertal group. The most distinct symptoms were fluttering, stereotypy of movements and visual/auditory hypersensitivity. On the other hand, the relational disturbance was less pronounced.

In the literature different reports have present data on the incidence of the fra $(X)$ syndrome in autistic children, ranging from $0 \%$ to $16 \%$ (see Wahlström et al, 1986).

Fow data are avallable on the frequency of autistic characteristics in fra $(X)$ patients. It is now estimated that $25 \%$ of fra $(X)$ positive males demonstrate autistic behavioural characteristics (see Brown et al, 1986).

With regard to the social functioning, fra $(X)$ boys in the present study performed silightly lower than the control group with a specific decline for 'soclalisation' and 'communication' abllities. We agree with the findings in different other studies : Bregman et al (1987) stated that the adaptive behavlour of $\mathrm{fra}(X)$ patients is better than expected from their Intelligence level, Loesch et al (1987) estimated that their good verbal and soclal performances are masking poor intelligence performances and Dykens et al (1987) concluded that fra $(X)$ boys are certainly applicant for early intervention programs, for they have optimal learning possibilities at pre-school age.

\section{REFERENCES}

Borghgraef, M., Fryns, J.P., Dielkens, A., Pyck, K. and Van den Berghe, $H$. 1987 Fraglle $(X)$ syndrome: a study of the psychological proflle in 23 prepubertal patients. Clin. Genet. 32: 179-186.

Bregman, J.D., Dykens, E., Watson, M., Ort, S.I. and Leckman J.F. 1987. J. 
Am. Ac. Child Psych. 26:463-471.

Brown, W.T., Jenkins, E.C., Cohen, I.L, Fish G.S., Wolf-Schein, E.G., Cross, A. Waterhouse, L., Fein, D., Mason-Brothers, A., Ritvo, E., Ruttenberg,

B.A., Bentley, W. and Castells S. 1986. Fragile $X$ and autism : a multicenter survey. Am. J. Med. Genet. 23: 341-352.

Dykens, E.M., Hodapp, R.M. and Leckman, J.F. 1987. Strengths and weaknesses in the Intellectual functioning of males with fra $X$ syndrome.

Am. J. Ment. Def. 92: 234-236.

Fryns, J.P. 1984. The fragile $X$ syndrome. A study of 83 families. Clin. Genet. 26: 497-528.

Fryns, J.P., Keczkowska, A., Kubien, E., and Van den Berghe, H. 1984. Cytogenetic findings in moderate and severe mental retardation. A study of an Institutionalized population of 1991 patlents. Acta Paed. Scand. Supplement 313.

Günzburg, H.C. 1977. Progress Assessment Chart of Soclal and Personal Development Manual (2 vols.). SEFA Publications Ltd., Birmingham. Jenssen-Hagerman, R. and McKenzle-McBogg, P. (eds) 1983. The Fraglle $X$ Syndrome. Diagnosis, Blochemistry and Intervention. Spectra Publishing, Dillon-Colorado.

Kohnstamm, G.A., Messer, A.P. and De Vrles A.K. 1971. De Utrechtse taalniveau Test voor 4-7 jarigen. p 5. Swets \& Zelttinger, Amsterdam.

Lachiewicz, A.M., Gullion, C.M., Spiridigliozzl, C.A. and Aylsworth A.S. 1987. Decline in IQ's of young males with the fra(X) syndrome. Am. J. Mental Retardation. 92: 272-278.

Largo, R.H. and Schinzel, A. 1985. Developmental and behavioral disturbances in 13 boys with fragile $X$ syndrome. Eur. J. Pedlatr. 143: 269-275.

Levitas, A., McBogg, P. and Hagerman, R. 1983. Behavioral dysfunction in the fraglle $X$ syndrome. In: $R$. Jenssen-Hagerman and $P$.

McKenzle-McBogg (eds). The Fragile X Syndrome. Dlagnosis, Biochemistry and Intervention. pp. 153-173. Spectra Publishing, Dillon-Colorado.

Loesch, D., Hay, D.A., Suthertand, G.R., Halliday, J., Judge, C. and Webb, G.C. 1987. Phenotypic variation In male-transmitted fra $(X)$ : genetic Inferences. Am. J. Med. Genet. 27: 401-417.

Newell, K., Sanborn, B. and Hagerman, R. 1983. Speoch and language dysfunction in the fraglle $X$ syndrome. In: $R$. Jenssen-Hagerman and $P$. McKenzle-McBogg (eds). The Fraglle $X$ Syndrome. Diagnosis, Biochemistry and Intervention. pp 175-200. Spectra Publishing, Dillon-Colorado.

Partington, M.W. 1984. The fragille X syndrome II: preliminary data on growth and development in males. Am. لJ. Med. Genet. 17: 175-194. 
Paul, R. and Leckman J.F. 1984. Behavioral phenotype. In: J.M. Opitz and G.R. Sutherland (eds). Conference Report. Am. J. Med. Genet. 17: $50-52$.

Reynell, J. 1977. Reynell Developmental Language Scales (revised).

N.F.E.R, Windsor, Berks.

Rhea, P., Dykens, E., Leckman, J.F., Watson, M., Breg, W.R. and Cohen, D.J. 1987. A comparison of language characteristics of mentally retarded adults with fra $X$ syndrome and those with nonspecific mental retardation and autism. Journal of Autism and Developmental Disorders, 17.

Rocchi, M., Archidiacono, N. and Filippi G. 1987. X-linked mental retardation: Martin-Bell syndrom. J. Génét. Hum. 35: 351-379. Snijders, J.T., Snijders-Oomen, N. 1975. Niet-Verbale Intelligentieschaal, S.O.N. 2 1/2 - 7. Groningen, Tjeenk-Willing.

Stinissen, J. and Vander Steene, G. 1981. W.P.P.S.I.: Wechsler Preschool and Primary Scale of Intelligence. Handleiding bij de Vlaamse aanpassing. p 158. Swets \& Zeitilinger, Amsterdam, Lisse.

Terman, L.M. and Merril, M.A. 1973. Stanford-Binet Intelligence scale, Form L-M : Manual for the third revision. Haughton-Mifflin, Boston.

Theobald, T.M. and Hay, D.A. 1982. Behavioural correlates of the fragile $X$ syndrome. Behaviour Genetics 12: 599.

Theobald, T.M., Hay, D.A. and Judge, C. 1987. Individual variation and specific cognitive deficits in the fra(X) syndrome. Am. J. Med. Genet. 28: $1-11$.

Van Berckelaer-Onnes, I.A., Harinck, F.J.H. and Smit, M. 1981. Auti-schaal. Ten behoeve van de onderkenning vam vroegkinderlijk autisme. p 24.

Swets \& Zeitlinger, Amsterdam, Lisse.

Van der Meulen, B.F. and Smrkovsky, M. 1983. Bayley

Ontwikkelingsschalen. BOS 2-30. Handleiding. p 183. Swets \& Zeitlinger, Amsterdam, Lisse.

Van Haasen, P. et al. 1985. Wechsller Intelligence Scale for Children.

Revised. Nederlandstalige Uitgave. Handleiding voor Instucties en Scoring. Swets \& Zeitlinger, Amsterdam, Lisse.

Veenema, $H$. and Geraedts, J.P.M. 1987b. The fra $(X)$ syndrome in a large family. II. Psychological investigations. J. Med. Genet. 24: 32-38.

Venter, P.A., Op't Hof and Coetzee, D.J. 1986. The Martin-Bell syndrome in South-Africa. Am. J. Med. Genet. 23: 597-610.

Wahlström, J., Gillberg, C., Gustavson, K.H. and Holmgren, G. 1986. Infantile autism and the fra $(X)$. A Swedish multicenter study. Am. J. Med. Genet. 23: 403-408. 


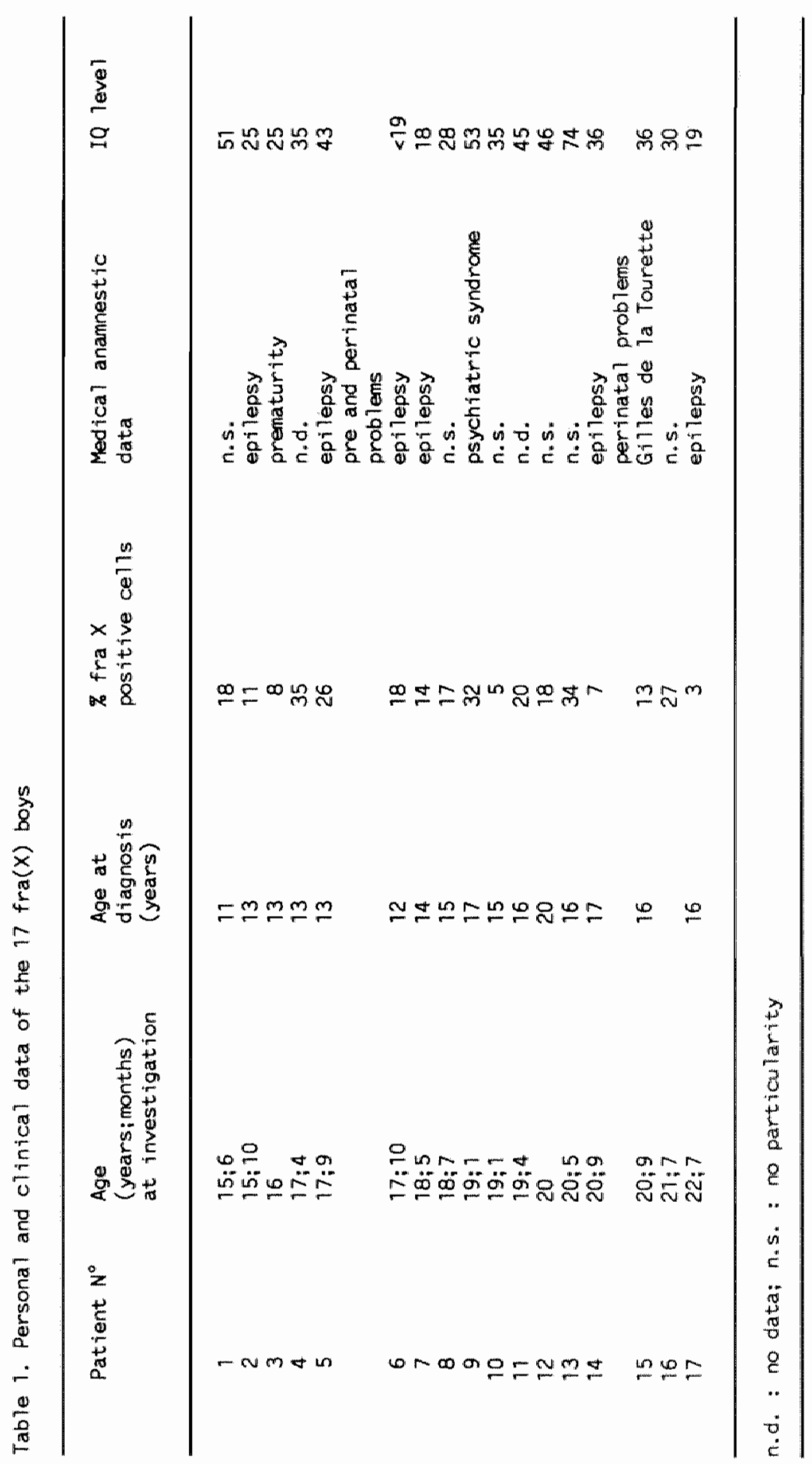


Table 2. Personal and elinical data of the 12 control boys

\begin{tabular}{lll}
$\begin{array}{l}\text { Pationt } \\
\text { numbar }\end{array}$ & $\begin{array}{l}\text { Age (years; months) } \\
\text { at investigation }\end{array}$ & IO level \\
\hline 1 & $15 ; 1$ & 52 \\
2 & $15 ; 8$ & 46 \\
3 & $16 ; 7$ & 31 \\
4 & $17 ; 3$ & 52 \\
5 & $18 ; 5$ & 31 \\
5 & $19 ; 3$ & 45 \\
7 & 20 & 38 \\
8 & $20 ; 5$ & 33 \\
9 & $20 ; 9$ & 30 \\
10 & $21 ; 4$ & 22 \\
11 & $21 ; 5$ & 49 \\
12 & 22 & 33 \\
\hline
\end{tabular}

Table 3. Proportional distribution of both groups of patients in relation to the intellectual level

\begin{tabular}{|c|c|c|c|c|c|c|}
\hline \multirow[b]{2}{*}{$\begin{array}{l}\text { Intel lectual level } \\
\text { (IQ distributtion) }\end{array}$} & \multirow[b]{2}{*}{ no. } & \multicolumn{2}{|c|}{ Fra $(x)$ boys } & \multicolumn{3}{|c|}{ Control-group } \\
\hline & & 7 & $\begin{array}{c}\text { Mean } \\
\text { IQ }\end{array}$ & no. & $\bar{x}$ & $\begin{array}{c}\text { Mean } \\
\text { IQ }\end{array}$ \\
\hline Mitd & 2 & 12 & 63 & 2 & 17 & 52 \\
\hline Moderate & 5 & 29 & 43.5 & 4 & 33 & 46 \\
\hline Severe & 7 & 41 & 30 & 6 & 50 & 30 \\
\hline Profound & 3 & 18 & $<19$ & 0 & - & - \\
\hline Total & 17 & & 34.4 & 12 & & 38.5 \\
\hline
\end{tabular}


Table 4. Proportional distribution of language and speech characteristics tim the $\mathrm{fra}(\mathrm{X})$ group and control group

\begin{tabular}{lcc}
\hline Characteristics & X fra $(x)$ boys $(n=17)$ & i control qroup (in=12) \\
\hline echolalia & 75 & 12 \\
Rapid speech rythm & 88 & 44 \\
Stuttering & 30 & 19 \\
Stereotypic speech & 82 & 12 \\
verbal unstructuredness & 42 & 35 \\
talktative & 36 & 38 \\
\hline
\end{tabular}

Table 5. Distribution of the Attention Deficit Hyperkinetic Disorder (ADHD) in both groups of patients

\begin{tabular}{lcc}
\hline Intel lectual level & $\begin{array}{c}\text { Fra(X) boys with ADHD } \\
\text { no. }\end{array}$ & $\begin{array}{c}\text { Control-group with ADHD } \\
\text { no. }\end{array}$ \\
\hline Mild & $0 / 2$ & $0 / 2$ \\
Moderate & $1 / 5$ & $0 / 4$ \\
Severe & $2 / 7$ & $2 / 6$ \\
Profound & $2 / 3$ & - \\
\hline $\begin{array}{l}\text { Total } \\
\text { Fisher"s exact }\end{array}$ & $5 / 17$ & $2 / 12$ \\
\hline
\end{tabular}


Table 6 Distribution of autistic behaviour in both groups of patients in relation to the intellectual level

\begin{tabular}{lcc}
\hline Intellectual level & $\begin{array}{c}\text { Fra( }(X) \text { boys with } \\
\text { autistic behaviour } \\
\text { no. }\end{array}$ & $\begin{array}{c}\text { Control-group with } \\
\text { autistic behaviour } \\
\text { nom }\end{array}$ \\
\hline Mild & $0 / 2$ & $0 / 2$ \\
Moderate & $0 / 5$ & $1 / 4$ \\
Severe & $3 / 7$ & $0 / 6$ \\
Profound & $1 / 3$ & $0 / 0$ \\
\hline $\begin{array}{l}\text { Total } \\
\text { Fisher's exact }\end{array}$ & $4 / 17$ & $1 / 12$ \\
\hline
\end{tabular}

Table 7. Mean percent of acquired abilities for each category of social functioning of the PAC1-2 (Gunzburg, 1977) in the fra(X) group and control group

\begin{tabular}{lcc}
\hline Categortes & fra( $x)$ group $(n=14)$ & $\%$ control group $(n=11)$ \\
\hline independence & 73.3 & 85 \\
communtcation & 38 & 44 \\
sociallisation & 41 & 63 \\
freetime occupation & 53 & 56 \\
\hline
\end{tabular}




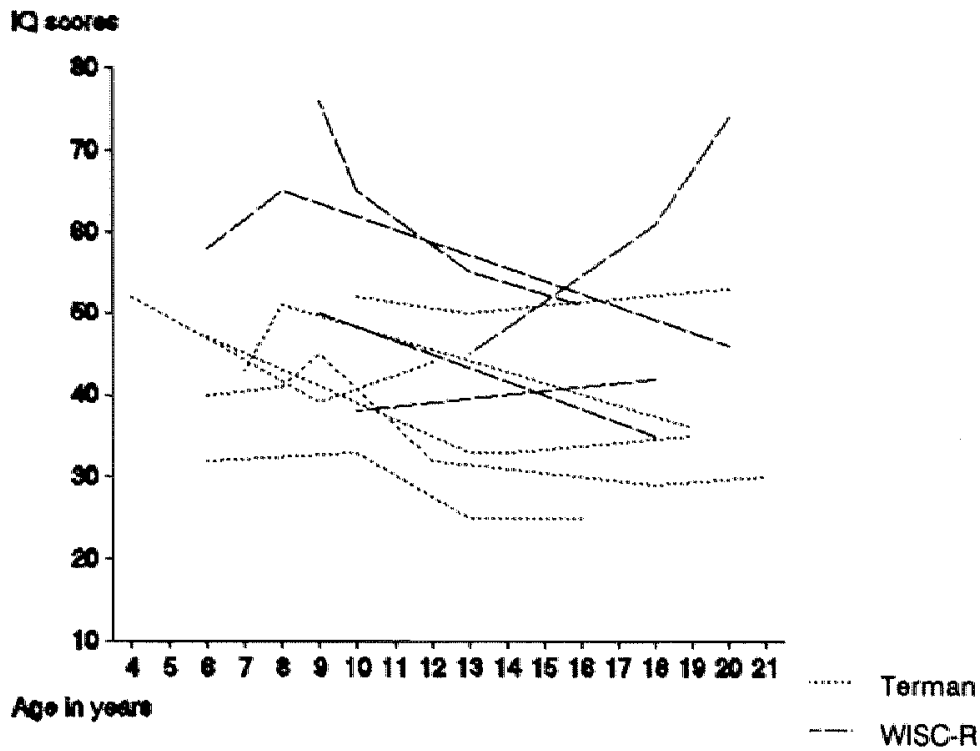

Fig. 1. Individual $\| Q$ scores at different ages of $1 \|$ fra $(X)$ boys

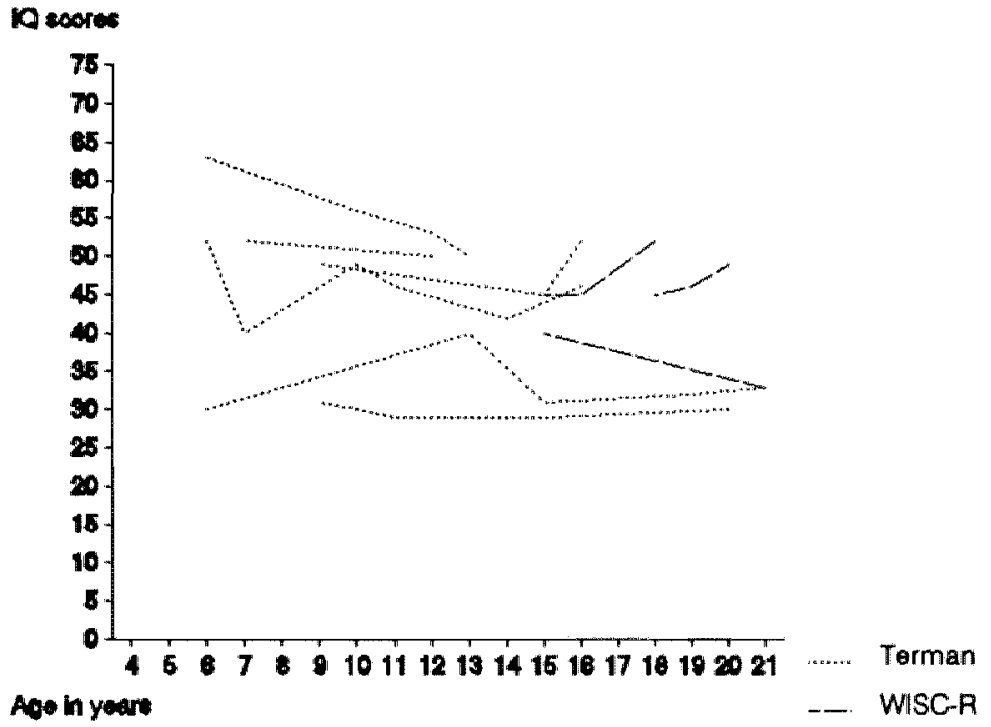

Fig. 2. Individual $\mathrm{LQ}$ scores at different ages of 9 control boys 

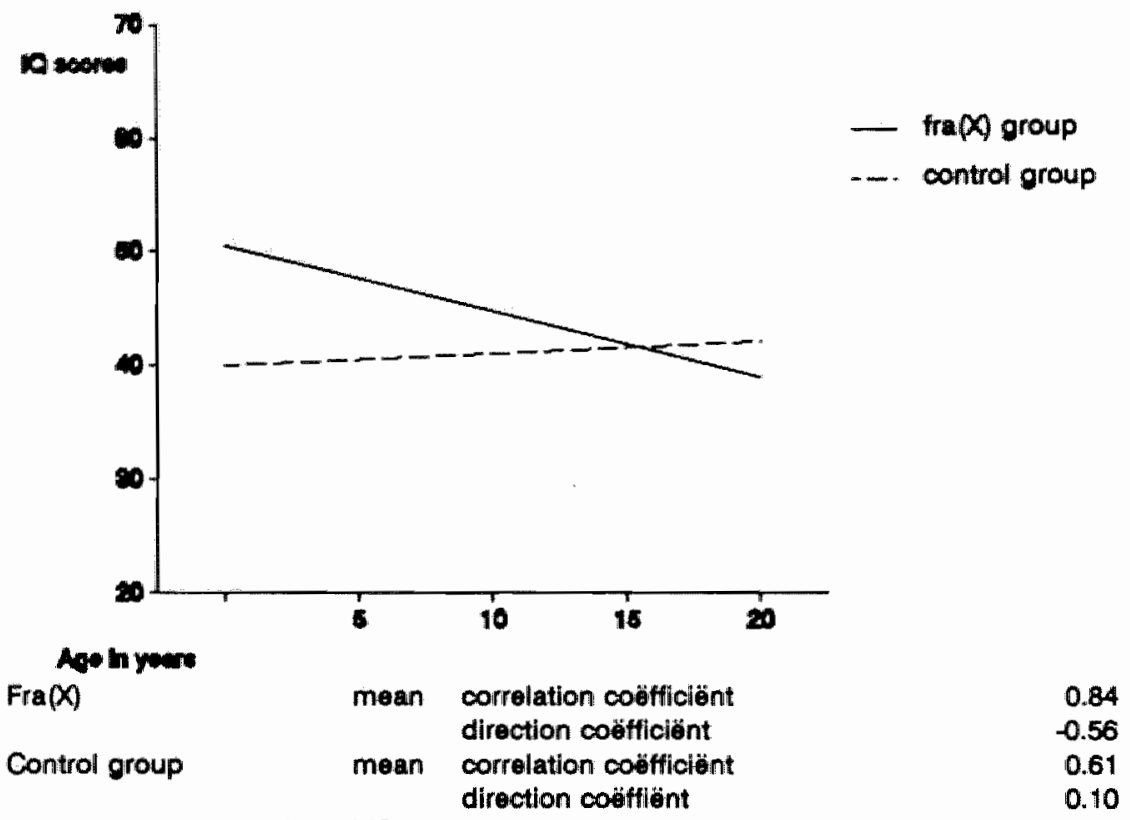

Fig. 3. The mean fluctuation of $1 Q$ with age in the fra $(X)$ group and the control group

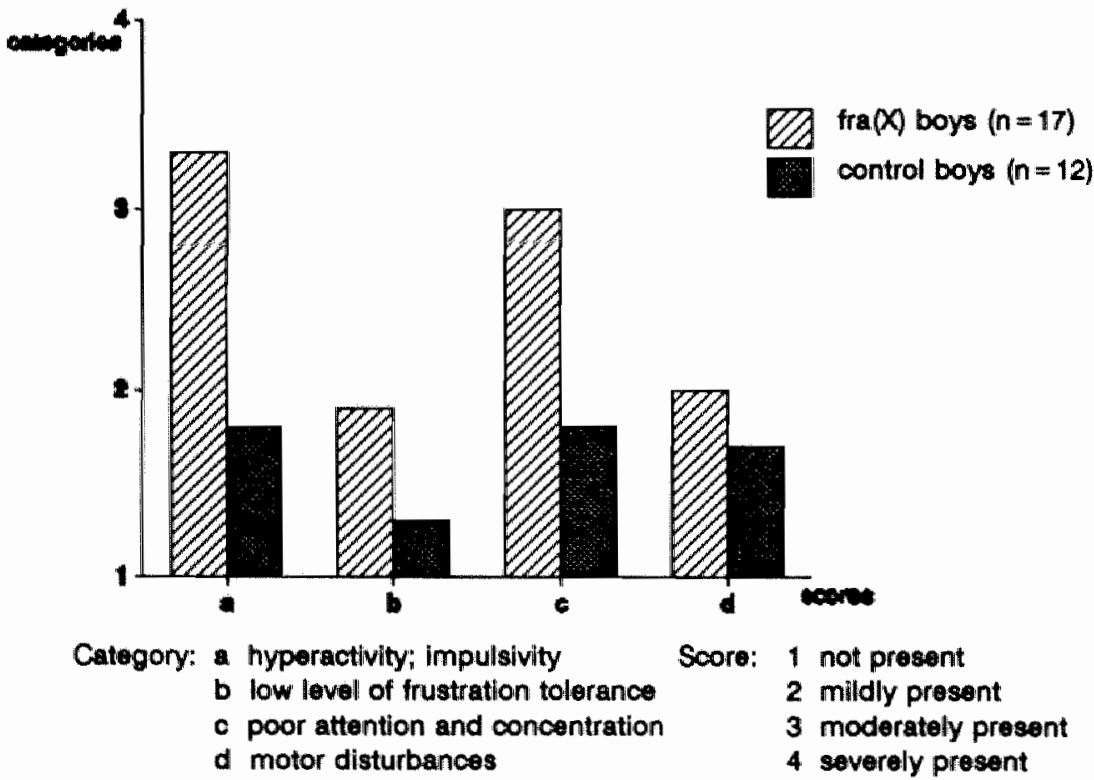

Fig. 4. Mean scores of both groups of patients for the 4 symptom categories of the Observation scale of hyperkinetic behaviour 


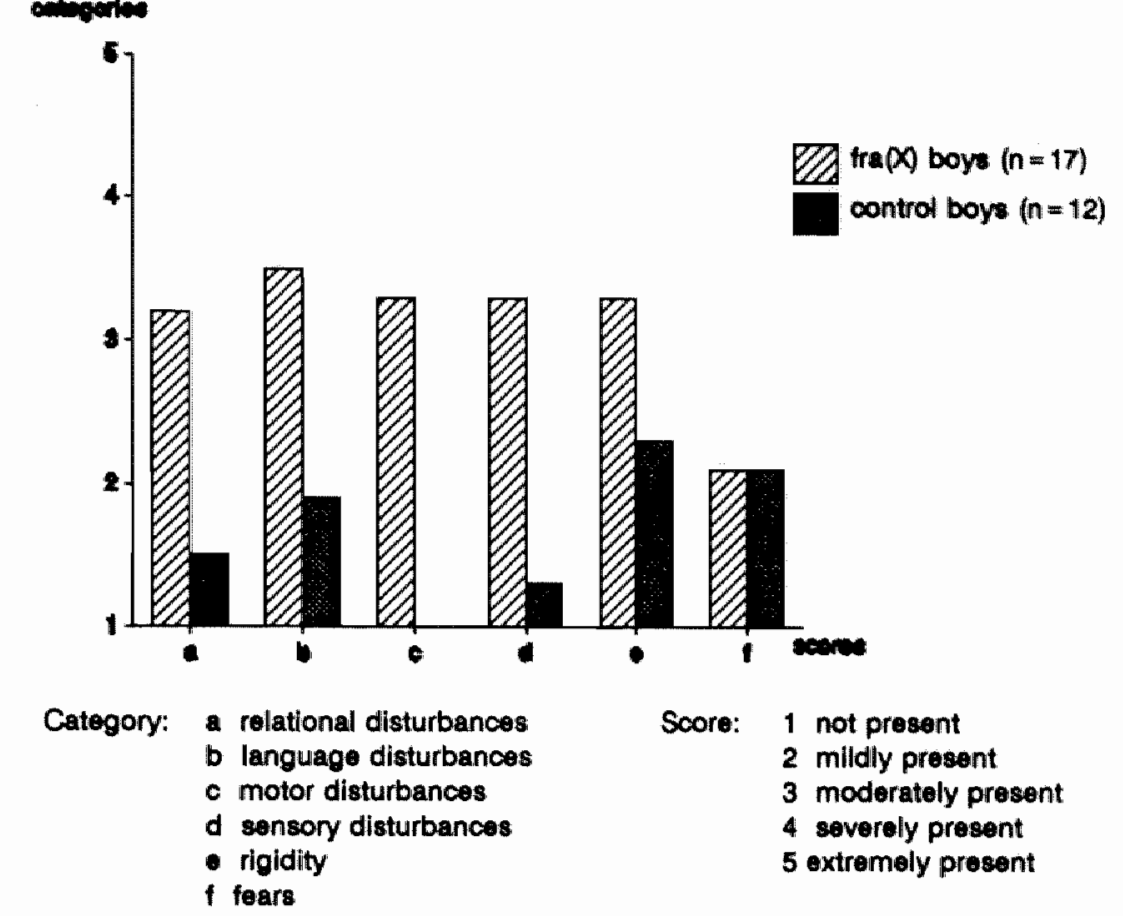

Fig. 5. Mean scores of both groups of patients for the 6 symptom categories of the Auti-3cale 

2c. INTELLUGENCE AND COGNITIVE PROFILE IN THE FRA (X) SYNDROME: A LONGITUDINAL STUDY IN 18 FRA $(X)$ BOYS 



\section{Intelligence and cognitive profile in the $\mathrm{fra}(\mathrm{X})$ syndrome: a longitudinal study in $18 \mathrm{fra}(\mathrm{X})$ boys}

\section{M G CURFS*, G SCHREPPERS-TIJDINK*, A WIEGERS*,} M BORGHGRAEFT, AND J P FRYNS $\uparrow$

From *Observation Centre De Hondsberg, the Netherlands; and †Centre for Human Genetics, University of Leuven, Belgium.

SUMMARY A longitudinal study of IQ and cognitive profile in $18 \mathrm{fra}(\mathrm{X})$ positive boys is reported. At the time of diagnosis, four of the boys were mildly retarded, seven were moderately retarded, and five were severely mentally retarded. Intelligence was borderline in one child and normal in another. A decline in intellectual performance with age in the fra( $X)$ syndrome indicated in previous studies was not confirmed and we review the reported data on this subject.

In the various studies of the psychological profile of the fra $(X)$ syndrome consideration has been given to the intellectual functioning of these males. In the jnitial studies a global estimation of their intellectual performance was given with or without further data on exact 10 measurements. In the majority of these reports, however, precise data on the type of IO tests were not given. ${ }^{1-9}$ In their study, McDermott et $a^{10}{ }^{10}$ reported the different types of IQ tests but did not include final results of these tests.

Different types of IQ tests have been used and most frequently reference is made to the StanfordBinet scale or Terman-Merrill scale and the Wechsler scales. ${ }^{11-23}$ In all the studies, cognitive function was evaluated on the basis of these traditional intelligence tests and in only a minority was consideration given to the broader spectrum of cognitive function. In the fragile $\mathrm{X}$ syndrome few data are available on the development of cognitive function and performance in relation to age. In most reports the authors discussed the results of cross sectional studies $^{7} 1517 \geq 22425$ and in the majority a decline in IQ in relation to age was reported.

The aim of the present study was to determine the fluctuation of IQ with age and to elaborate the different cognitive functions of fra $(X)$ boys.

\section{Methods and results}

In this study intellectual function and cognitive profile of $18 \mathrm{fra}(\mathrm{X})$ positive males* was analysed.

"One of the patients is an advilt.
The fragile $X$ syndrome was diagnosed in 15 boys during observation in De Hondsberg, an observation clinic for mentally retarded and/or behaviourally disturbed children and adolescents in the southern part of the Netherlands.

The three other boys had not been admitted to the clinic. One of them was a brother of a $\mathrm{fra}(\mathrm{X})$ patient in De Hondsberg, and he was ascertained through family research. Two males* had been diagnosed through the external service of the cytogenetics laboratory of De Hondsberg. In the period 1983 to 1986 a fragile $X$ study was performed in 341 patients, 311 males and 30 females. Fra(X) was found in 24 males. Four boys were not included in the study, two because their parents would not give consent and two because their families had emigrated. Two other boys had been tested for intelligence more than once by means of various tests, which made comparison difficult. These boys were therefore excluded. Psychological and clinical data of the 18 boys are summarised in the table.

INTELLIGENCE

In the 18 boys $1 Q$ evaluations were performed at regular intervals using either the Terman-Merrill or Wechsler scales. At the time of diagnosis the 10 level of the 18 fra $(X)$ positive boys varied greatly (table). Intelligence was normal in one boy and borderline in another, and four were mildly, seven moderately, and five severely mentally retarded (AAMD classification). In these last five patients the severe retardation, with $I Q$ measurements below 30 , was present from the beginning. Further testing showed no changes in level over time. "The fluctuation of the IQs between the ages of four and 17 in the other 13 boys is shown in fig 1. 
TABLE Prochological and thrical featheres in 18 fra $(X)$ positive boys.

\begin{tabular}{|c|c|c|c|c|}
\hline $\begin{array}{l}\text { Prosiral } \\
\text { age }\end{array}$ & 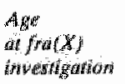 & 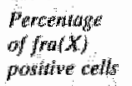 & $\begin{array}{l}\text { Degree } \\
\text { of manat } \\
\text { refardaron }\end{array}$ & $\begin{array}{l}\text { Skanl } \\
\text { centifteg }\end{array}$ \\
\hline$y$ & 4. & 2 & Modecrate & $75+4 t$ \\
\hline 9 & 4 & $23 / 2$ & Mintis & 2.5117 \\
\hline 12 & 9 & 3 & Modwarate & $50 \mathrm{th}$ \\
\hline 34 & 37 & 4 & Savertitic & 50 th \\
\hline 21 & 17 & 4 & Moglerate & 50 th \\
\hline 12 & 7 & 6 & Mitd & 75 uh \\
\hline 6 & 4 & 10 & Severe & $80 \mathrm{hth}$ \\
\hline 8 & 6 & 19 & Borderiline & Wo datia \\
\hline 16 & 13 & 15 & 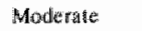 & 30 the \\
\hline 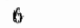 & 4 & 17 & Severe & Alith \\
\hline 9 & 6 & 19 & Moderale & $40 \mathrm{th}$ \\
\hline 15 & 3 & 20 & Mild & $50 \mathrm{ih}$ \\
\hline$\$$ & 5 & 24 & Mild & $97 \mathrm{kr}$ \\
\hline 8 & 由 & 28 & Moder atsc & Goith: \\
\hline 11 & 8 & 30 & $\begin{array}{l}\text { Wol menendisty } \\
\text { retharded }\end{array}$ & $50 \mathrm{dh}:$ \\
\hline 8 & 8 & 32 & Severe & $10 \mathrm{th}$ \\
\hline 13 & 8 & 60 & Mortlerate & $50 \mathrm{~m}$ \\
\hline 10 & 6 & 62 & Severe & Ioth \\
\hline
\end{tabular}

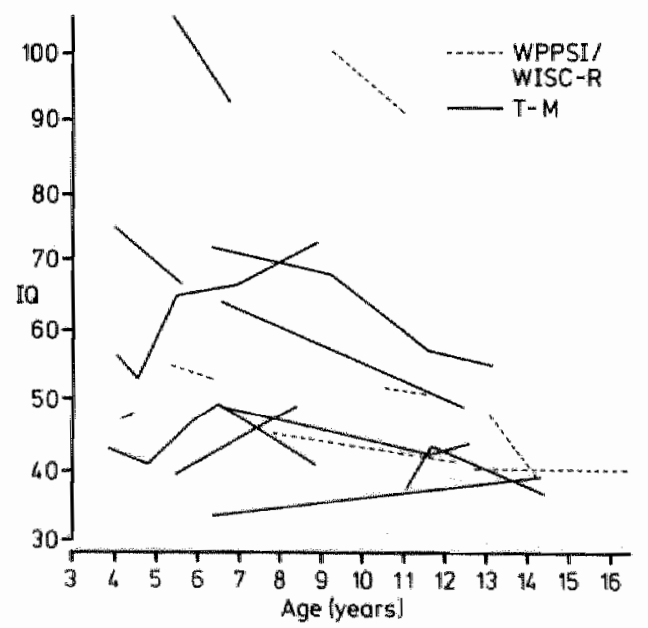

Fic I Age wariation of $1 Q$ in 13 fra $(X)$ positive boys (Terman-Merrill scale and WPPSWWISC-R sess).

A decline in intellectual performance with age was seen in four boys. In three, however, there was a significant increase in 10 scores, whereas in the remaining six children no fluctuation in IQ was observed (confidence interval $68 \%$ ). At the $95 \%$ confidence level no IQ variation was found in 11 boys. In wo of these the increase in IQ score was on the borders of significance. In the other two boys there was a significant decline in intelligence scores.

VERGAL AND PEFORMANCE INTELLIGENCE TESTS We were able to obtain data on verbal and performance intelligence in five fra( $X)$ toys with

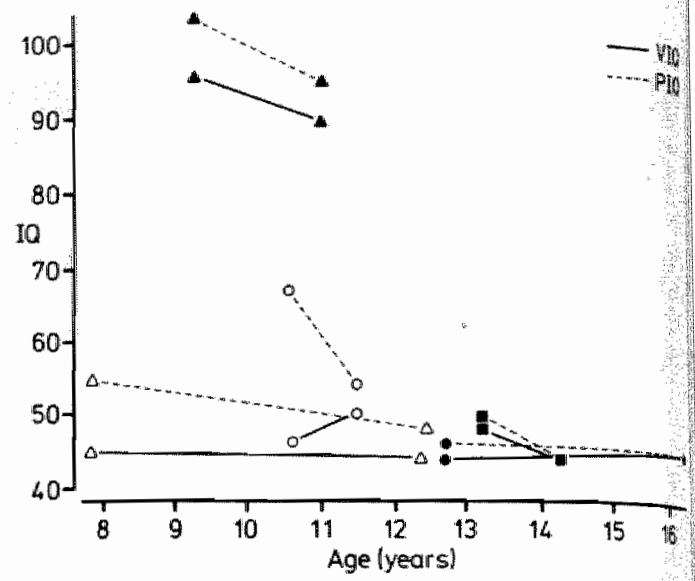

FG 2 Variation of verbal and performance IQ (WISC.PI)

measurements at two different ages with the WISCR test. These results are summarised in fig 2 . The discrepancies between verbal and performance Io were small with relatively better results in perform ance tests. This difference, however, was ondy significant in one evaluation in one boy.

\section{Dïscussion}

Precise IQ testing and subclassification according to the AAMD classification of the $18 \mathrm{fra}(X)$ boys in the present study indicated a marked variation in intelligence. In one boy normal intelligence was found and one other showed borderline intelligenes. Normal intelligence has rarely been documented after precise 10 testing in the fra $(X)$ syndrome Veenema $e t a l^{20}$ reported two normal intelligen boys in a study of 17 fra $(X)$ positive boys. Frynts et al observed normal intelligence in one fra( $X)$ boy in their study of the psychological profile of pie pubertal and adolescent fra(X) males.

In a critical review Madison ef $a^{27}$ concluded that most studies on the intellectual performance in the $\mathrm{fra}(\mathrm{X})$ syndrome subdivide the patients into differeni categories on the basis of different types of classification. This may result in important differences in the final classification and subgrouping of the patient material. The AAMD classification was applied in some of the previous studies. ${ }^{7}{ }^{23}$ Madison et $a^{27}$ also stressed that the variation in results is further increased by the application of different 10 tests in different studies. In the present study 10 testing was performed with the Wechsler scale and the Stanford-Binet test ${ }^{23-30}$ and the results of both are presented separately. Different tests were also applied in previous studies. ${ }^{22}{ }^{23}$ Comparison of the 
results of different tests may lead to false interpretations; for example, Newell $e t a l^{16}$ reported a lower non-verbal IQ (on the Leiter test) compared to the total IQ (Stanford-Binet test). However, underestimation of the intellectual level with the Leiter test is well documented. Few systematic data are available on the variation of intellectual performance in the fra $(X)$ syndrome in relation to age. Most studies report retrospective IQ data obtained on different IQ scales by different persons. The majority of these data suggest a decline in intellectual functioning in relation to age. ${ }^{7151719} 22-25$ Only a few reports include data on longitudinal IQ determinations, mostly on a small number of patients. Rhoads, ${ }^{19}$ Partington, ${ }^{7}$ and Hagerman et a ${ }^{15}$ each reported data on the longitudinal follow up of four patients. They all described a decline in intellectual performance. Precise information on the type of IQ tests and the degree of regression was only presented by Hagerman et al. ${ }^{95}$ Primrose et a $l^{21}$ compared actual IQ scores of 40 fra $(X)$ males with previous IQ measurements on the Stanford-Binet scale. In 21 patients severe retardation $(\mathrm{IQ}<30$ ) was present on two separate tests. In 10 males a significant decline in IQ was observed over a period

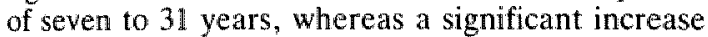
in intellectual performance was observed in three $\mathrm{fra}(\mathrm{X})$ adult males over a period of 11 to 39 years. Borghgraef $e r a^{23}$ noted a decline in IQ in three of the seven $\mathrm{fra}(\mathrm{X})$ boys analysed ... their study. In these patients, IQ tests (WISC-R or Terman-Merrill) were repeated after a period of three to four years. In the present study we did not observed this decline in intellectual performance with age in the longitudinal follow up of 16 of the $18 \mathrm{fra}(X)$ boys,

In the present study there was no significant difference between the results of the verbal and performance subtests in five $\mathrm{fra}(\mathrm{X})$ boys. Up to now, few data have been availlable on possible discrepancies between verbal and performance intelligence in the $\mathrm{fra}(X)$ syndrome. The results of most studies are inconclusive ${ }^{711} 121 \% 31$ : in some patients verbal $1 \mathrm{Q}$ was lower than performance $\mathrm{IQ}$ and the other way round in others. The possible relationship between non-verbal intelligence and verbal expression in fragile $X$ patients was studied by Paul and Leckman ${ }^{32}$ and Newell et al. ${ }^{16}$ Paul and Leckman ${ }^{32}$ observed a correlation between verbal expression and non-verbal intelligence (Leiter or WISC-R) while Newell et $a^{16}{ }^{16}$ reported better results in receptive language (PPVT test) than in visualperceptive tasks. Varley et a $t^{20}$ described a significantly higher verbal IQ score in one $\mathrm{fra}(\mathrm{X})$ boy compared to the results on performance IQ tests (WISC-R) and higher scores on the subtests Comprehension and Similarities. From these data the authors concluded that social competence is relatively well developed in the fra $(\mathrm{X})$ syndrome. Chudley et $\mathrm{al}^{\text {is }}$ and Dielkens ${ }^{31}$ observed no differences in verbal and performance IQ in their study of 29 and six fra $(X)$ males respectively. The lowest results in subtest scores were observed in Picture Completion, Similarities, and Picture Arrangement. In mildly retarded fra $(X)$ boys, Borghgraef et al $l^{23}$ reported low scores on concentration and attention (Digit span and Coding subtests) and better results on visuospatial perception and synthetic-analytic skills (Block Design and Object Assembly). These differences were not observed in moderately mentally retarded fra $(X)$ boys. With the Kaufman Assessment Battery for Children, Dykens et $a l^{33}$ studied the variable aspects of cognitive functioning. In 14 $\mathrm{fra}(\mathrm{X})$ boys, aged between two and 20 years, they observed lower scores on sequential processing (short term memory auditory, visual, and motor skills) compared to the results on simultaneous processing measuring perceptual flexibility and alertness.

Based on the data available, no definite conclusions can be drawn about possible patterns in the development of cognitive profiles in the $f r a(X)$ syndrome with age. In most studies the number of young fra $(X)$ boys is very small ${ }^{15} 2432$ or data are reported on one or more fra $(X)$ males in one family. ${ }^{20}$ Madison et $a l^{27}$ concluded that these aspects should be studied further in the $\operatorname{fra}(X)$ syndrome with the application of verbal and performance IQ tests to augment the general IQ tests.

\section{Refferences}

1 Turraer G, Daniel A. Frost M. Xulinked mentat retardation, macromorchidison and the Xep fragile sitc. I Pedidur 1980,96 : $837-41$.

${ }^{2}$ Blonquist HK, Gustavson KH, Holmigren O. Nordenson I. Swe uns A. Fragile site $X$ ahromosomes and $X$-linked nachal retardation in severely retarded boys in al northern 5 wedish county. A prevalence study. Cho Genet 1982:21:209.14.

${ }^{3}$ Van Roy BC. DeSmed MC. Racs RA, Dumon JE, Leroy JG Fragile $X$ trail in a large kindred tramsmission atso through normal matles. I Med Gener 1983;20:286m9

${ }^{4}$ Pueschel SM. Hays RM. Mendoza T. Famulial X-linked mental retardation syndrome ilsociated with minor congenillal ano-

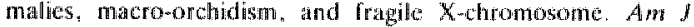
Meni Defic 1983;87:372-6

Fryns JP, Van den Berghe H. The fragile $X$ syndrome. A study of 83 families. Chn Gent 1984;26:497-528.

"Fryns JP. Jacobs $\mathbb{J}$, Kleczkowsika A. The psychological profile of the fragile $X$ syndrome. Com Genet 1984:25:13 $11-4$

Partington MW. The fragile $X$ syradrome. II Preliminary data on growh and dewelopment in malks. Am $l$ Med Genet $1984: 17: 175-94$.

* Gustavson KH, Dahlbom K. Flood A. Molmgren Gi Blomquist $H K$, Sanner $O$. Effects of follic acid ureat ment in the tragite $\mathrm{X}$ syndrome. Chin Genet 1985:27:463-7.

"rurner G. Robinson H, Laing $S_{n}$ Purvis-Smith $\$$. Prevontive screaning for the fragine $X$ syndrome. N Engl I Med 1986;315; $607-9$ 
9i MeDernot A, Walters $R$, Howell RT, Gardner A. Fragile X chromosome: clinjeal and cylogenctic studies on cases from geven farmilies. 1 Med Oene $1983,2016978$.

"Howard PGebles PN, Stoddard GR. X linked mental retardation with macrowendism and marker X chromosonwes. Huw Genet $1979 \cdot 50 \div 247-51$.

12 Howard-Peebles PW, Shoddard GR, Mims MG Familial X-linked mental retardation, verbal disabutity and roarker X chiromotomes. Am J Hum Gene 1979,31:21422.

1. Gustaven KH, Holmgren G, Blomguist HK, af al. Familial $X$ linked mental reterdation and fragile $X$ chromosomes in two Suredisin families. Clin Genet 1981:19:101-10.

14 Nielsen KB. Diagnosis of the fragle X-syndrome (Martin-Bell syndrome $)$. Clincal findings in 27 males with the fragile site at Xq29. I Men Defic Res 1983;27:211-26.

\# Hagerman $\mathbb{R}_{\mathrm{S}}$, Smith ACM, Mariner R. Clinical features of the

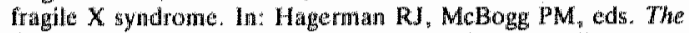
fragule $X$ syndrome. Diagnosis, biochemistry and inverventom. Dillon: Spectra, 1983:17-53.

va Nell K. Sanborn B. Hagerman RJ. Speceh and language dysfunction in the fragite $X$ syndrome. In: Hageman RJ, MCBogge PM, eds the fragile $X$ syndrome Diagnosis, biow chemistry and intervention. Dillon: Spectra, 1983:175-200.

17 Chudley AE, Knoll J, Gerrard JW, Shepel L, McGathey E, Anderson J. Fragile (X) X-linkad mental retardation, L. Relation:slup betwerenge and intelligence and the frequency of axpression of fragile (X) $(q 28)$. Awn I Med Gener 1983;14: $699-712$.

I敞 Chudley AE. Shepel L, McQahey IE, Knoll J, Gerrard JW. Beliswioural phenotype. Conference report. Am I Med Genes $1984: 17: 45-50$.

19 Rhoads IfA. Fragile- $X$ syndrome in Hawait: a summary of clinical cxperience. A $m$ J Med Genet 1984:17:209m14.

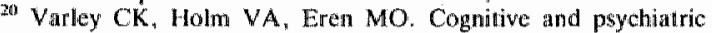
wariability in three brothers with fragile $X$ syndrome. $\&$ Dew Behau Pediar 1985;6:87-400.

"Primmose DA, Elmatmati $R$, Boyd E, Gosden $C$, Newton M. Prevalence of the fragile $X$ syndrome in an institution for the mentally handicapped. Br I Psychiary 1986;148:6557.
22 Rogers $\mathrm{RC}$, Simensen $\mathrm{RI}$. Fragle $\mathrm{X}$ syndrome: etiology of mental retardation. Am J Ment Defic 1987,91448

2* Borghigrael M. Fryns JP. Dielkens A, Pyck K Van den Berglat Fragle $(X)$ syndrome: a study of the psychological profile in prepubertal patients. Clin Genes 1987;32:179-86.

2.4 Levitas A, McBogg PM. Hagerman $\mathbb{R J}$. Behavioral dysfuactial in the fragile $X$ syndrome. In: Hageman RJ, McBogg PM, The fragile $X$ syndrome. Diagnosis, biochemistry and intervento Dillon: Spectra, 1983:153-73.

25 Largo RH, Schimel A. Dewelopmental and behavioral distuh ances in 13 boys with fragile $X$ syndrome. Eur $f$ Peds $1985 ; 143: 269-75$

26 Veenerna $H$. Pelckmans AJM, Veenema T. Hel fragiele syndroom. Bulleim wan de Nationale Ziekenhuisrand (NZ) $1965: 18: 35-9$

${ }^{27}$ Mádison LS, Mosther GA, George CH. Fragille-X syndrom diagnosis and research. I Pediatr Psychoi 1986;11:91-102.

2 Wechster D. Mannal for the Wechsier preschool and priman scales of intelligence. New York: The Psychological Corporatimi 1967.

* Wechsler D. Manual for the Wechsler intelligence scale for children-revised. Miew York: The Psychological Corporition 1974.

30 Terman LM, Merrill MA. Stanford-Binet intelligence nots Manual for the third reviston form $L-M$. Chicago: Riversid Publishing Co, 1973.

3 Dielkens A. Het intellectued niveau. In: Het frogight X-wyndroom. Scriptie, Leuven, Katholieke Universiteit, 19g: $76-84$

12. Paul R, Leckman JF. Behavioural phenotype. Conferentit repott. Am J Med Genet 1984:17:50-2.

33 Dyken EM. Hodapp RM, Leckman JF. Strengths and weal messes in the intellectual functioning of males with fragl X syndrome. Am J Ment Defic 1987:92:234-6.

Correspondence to Dr J P Fryns, Centre for Human Genetics, Herestraat 49, 3000 Leuven, Belgium. 
2d. STRENGTHS AND WEAKNESSES IN THE COGNITIVE PROFILE OF FRA(X) PATIENTS 



\title{
Strengths and weaknesses in the cognitive profile of fra(X) patients
}

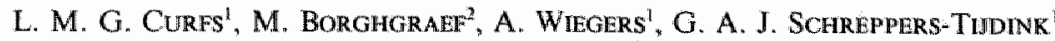 \\ AND J. P. FRYNS'1
}

Observation Centre De Hondsberg, Oisterwijk, The Netherlands and ${ }^{2}$ Centre for Human Genetics. Department of Human Biology, University of Leuven, Belgium

In this paper we present data on the cognitive abilities analyzed by systematic, standardized psychometric testing in $18 \mathrm{fra}(\mathrm{X})$ boys who participated in a multicenter, longitudinal study. In the majority of the patients no significant differences were found between verbal and performance intelligence. Higher performance IQ than verbal IQ was found primarily in higher functioning fra( $X)$ males, indicating a possible effect of level of functioning on the direction of verbal-performance IQ differences. Subtest-analyses showed lowest performances in Number Concept and Arithmetic Skills, whereas better performances were reached in Object Assembly and Picture Completion. These data are discussed and compared with the results in previous studies reported up to now.

Received 15 March, revised 15 May, accepted for publication 23 May 1989

Key words: cognitive functioning; fra(X) syndrome; performance IQ; psychological profile; verbal intelligence.

Most studies on the psychological characteristics in the $\mathrm{fra}(\mathrm{X})$ syndrome are limited to the intellectual functioning of the patients. Results show a wide variation in intellectual functioning. The intelligence of the majority of the male patients is at the moderately to severely retarded level (Bregman et al 1987, Madison et al. 1986b, Sutherland \& Hecht 1985). It is noteworthy that such studies give only an estimation of the intellectual performance of the patients, without further data on exact IQ measurements (Curfs et al. 1988).

Little is known about the broader spectrum of cognitive functions and the specific structure of cognitive abilities in the fragile $\mathrm{X}$ syndrome, and so far there have been few systematic studies on the cognitive profile in $\mathrm{fra}(\mathrm{X})$ boys. The aim of the present study was to determine specific strengths and weaknesses in cognitive functioning in $\mathrm{fra}(\mathrm{X})$ boys.

\section{Methods and Results}

\section{Intelligence}

In this study the intellectual functioning and cognitive profile of $18 \mathrm{fra}(\mathrm{X})$ positive boys was analyzed. Intelligence was measured with the WISC-R, (Wechsler 1974, Haasen et al. 1986)'. The patients are participating in a multicenter ${ }^{2}$ longitudinal study. Only

'For six patients the Flemish version of the WISC was used (Lagae \& Coetsier 1963).

${ }^{2}$ A fragile $\mathrm{X}$ syndrome for 6 patients was diagnosed at the Hondsberg, an observation clinic for mentally retarded and/or behaviourly disturbed children and adolescents in the sowthern part of the Netherlands, and for 12 patients at the Centre for Human Genetics of the University of Leuven in Belgium. 
the most recent intelligence data are presented here. Psychological data, including the percentage of $\mathrm{fra}(X)$ positive cells and age at investigation are summarized in Table 1.

The age of the patients varied from 8 years to 21.5 years. Three boys were older than the upper age limit of the WISC-R $(178 / 12,19$ and $215 / 12$ years old, respectively), so their IQ's could only be estimated. However, since we are concerned here with relative strengths and weaknesses in cognitive abilities, the absolute score is not relevant and they can be included in our study.

The IQ level of the $18 \mathrm{fra}(\mathrm{X})$ positive boys varied greatly (see Table 1). Intelligence was normal in one boy, three were mildly, six moderately and one severely mentally retarded (AAMD classification). Because of an IQ below 46 or $45^{3}$, seven boys belonged to the category moderately or severely mentally retarded.

\section{Verbal and Performance Intelligence}

Using the tables in the WISC-R manual, a significant difference between performance IQ and verbal IQ was found for six patients $(p<0.05)$. Five of them had a higher performance IQ and one boy's verbal IQ was higher than his performance IQ. For the other 12 patients no significant discrepancies between verbal and performance IQ were observed.

\section{Pattern of Abilities}

To examine the question whether there is a specific pattern of disability for fra $(X)$ patients, subtest scaled scores of an individual patient, as presented in Table 1, were compared to the mean scaled score for that particular child. Comparisons are made for 46).

${ }^{3}$ (Flemish version limit 45, Dutch version limit the verbal scale, performance scale and for the test as a whole (Sattler 1982).

Eight patients showed one or more significant differences. Two patients showed a significantly higher score in Object Assembly; two patients in Picture Completion; two in Picture Completion and Object Assembly; one in Picture Completion and Block Design; and one patient in Comprehension. So most of the highest subtest scores were found on the performance scale, especially Object Assembly and Picture Completion. These high scores imply good perception and alertness to details, and a good ability to visualize a whole from its parts (Sattler 1982).

Significantly low scores were found for three patients: for one patient in Coding, for one patient in Coding and Digit Span and for one patient in Arithmetic. All these subtests score high on the factor freedom from distractibility. It is difficult to draw a conclusion because of the incidental occurrence.

It is also interesting to look at the cognitive strengths and weaknesses within the verbal and performance scale. On the performance scale, the highest scores were in Object Assembly (three patients) and Picture Completion (one patient) and for one patient in Object Assembly and Picture Completion. The lowest scores were found for Coding (two patients) and Picture Arrangement (one patient).

In general, scores on the verbal scale were low. In two patients, however, their highest scores were in Comprehension. This reflects good social judgement and common sense. For none of the patients was a significantly low verbal score obtained.

Looking at the spread of subtest-scores of the mentally retarded fra( $(X)$ patients, the highest variation is seen in Object Assembly (scaled scores 1 to 12) and the lowest variation in Arithmetic (scalled scores 0 to 2).

For the other subtests the scaled scores 
COGNITIVE PROFILE IN FRA(X)

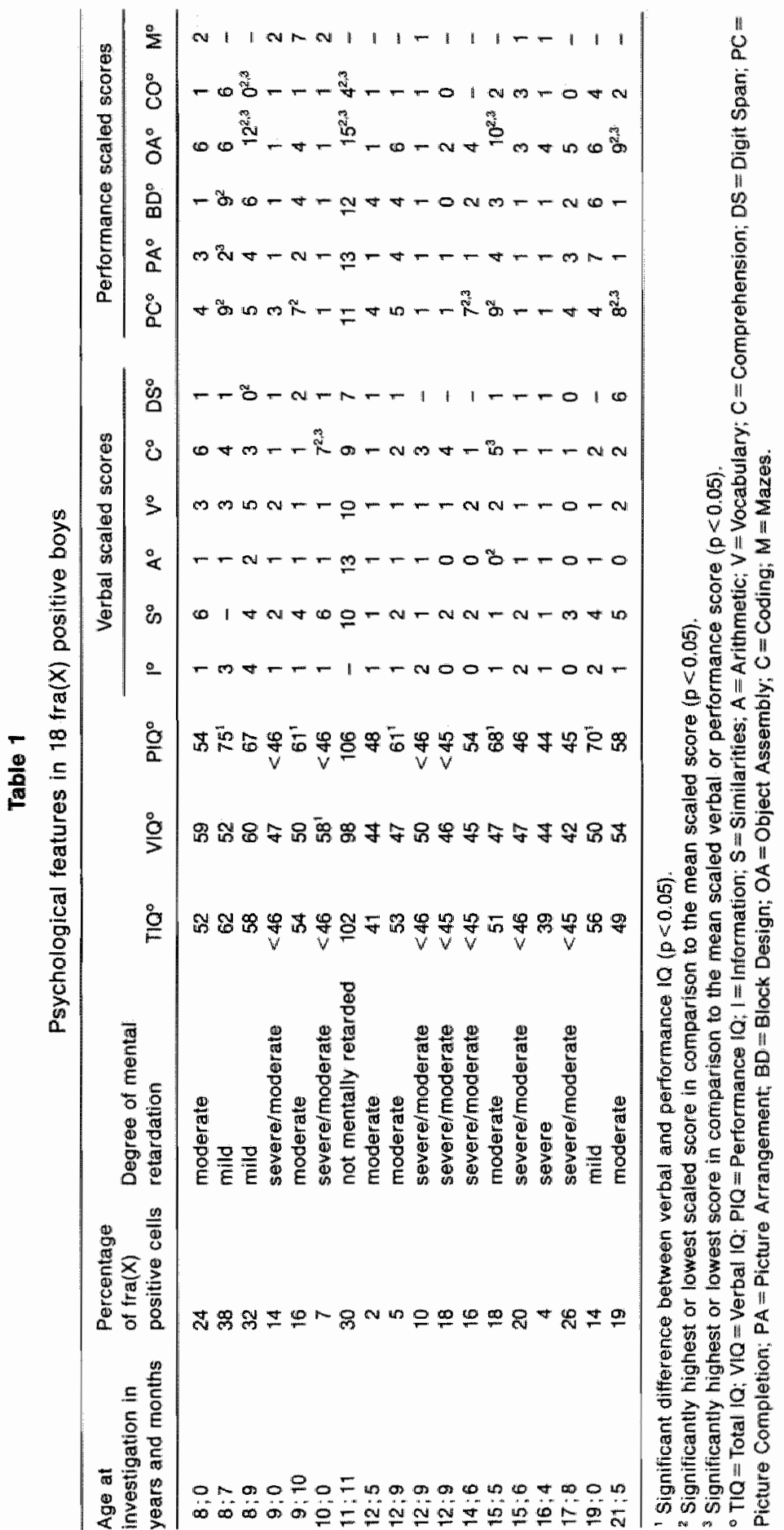


varied from 0-4 (Information); 1-6 (Similarities); 0-5 (Vocabulary); 1-7 (Comprehension); 0-6 (Digit Span); 1-9 (Picture Completion); $1-7$ (Picture Arrangement); 0-9 (Block Design); 0-6 (Coding) and 1-7 (Mazes).

\section{Discussion}

In this study the pattern of cognitive abilities of fra $(X)$ patients was analyzed by systemic standardized psychometric testing. The WISC-R was administered to all patients. In most studies on cognitive abilities, only selected subtests have been used and sometimes age-inadequate tests (Herbst et al. 1981, Madison et al. 1986a, Theobald et al. 1987, Veenema et al. 1987). In the present study a considerable variation in intellectual functioning was found, with moderate to severe mental retardation in the majority of the affected males. This is in agreement with the findings in previous studies (Bregman et al. 1987, Madison et al. 1986b, Sutherland \& Hecht 1985). One patient was not mentally retarded. The incidental finding of normal intelligence has also been reported in other studies (Daker et al 1981, Nielsen et al. 1981, Webb et al. 1981, Daker et al. 1982, Fryns 1984, Hagerman et al. 1985, Theobald \& Hay 1987, Veenema et al. 1987).

Up to now few data have been available on possible discrepancies between verbal and performance intelligence in the $\mathrm{fra}(\mathrm{X})$ syndrome (Eren \& Disteche 1983, Chudley ef al. 1984, Hagerman et al. 1985, Dielkens 1986, Madison et al. 1986a. Theobald \& Hay 1987, Veenema et al. 1987). In some other studies discrepancies are only briefly mentioned (Renier et al. 1983, Varley et al. 1985, Goldfine et al. 1987, Howard-Peebles et al. 1979, Howard-Peebles \& Stoddard 1979, Partington 1984, Rhoads 1984). Chudley et al. (1984), Eren \& Disteche (1983) and Dielkens (1986) did not find any differences between verbal and performance
IQ in their study of 29,10 and $5 \mathrm{fra}(\mathrm{X})$ patients, respectively. Differences between verbal and performance intelligence were reported by Theobald \& Hay (1982), Hagerman et al. (1985), Theobald et al. (1987) and Veenema et al. (1987). These studies suggest higher verbal than performance scores on intelligence testing. In the present study, however, this result was only found for one patient. For five of the patients performance capacity exceeds verbal intelligence, a result also reported by Madison et al. (1986a). The majority of the patients in our study did not show any significant differences between verbal and performance intelligence. However, looking at intelligence levels, it is interesting to note that higher performance than verbal IQ is found primarily in higher functioning $\mathrm{fra}(\mathrm{X})$ males. In the lower functioning males (severe or severe/moderate retardation) there seems to be a somewhat higher verbal than performance intelligence score, although only in one patient was this difference significant. The significance of differences between verbal and performance IQ, however, is difficult to establish in low scores, since the WISC-R officially does not measure IQ's under 45. This finding of a possible effect of level of functioning on the direction of verbal-performance $\mathrm{IQ}$ differences is interesting, since it might imply that the cognitive level of the population investigated is important in interpreting cognitive profiles in the $\mathrm{fra}(\mathrm{X})$ syndrome.

For the majority of the patients (10 out of 18), subtest analysis showed no significant differences between subtests. Results of subtest analyses on the Wechsler-scales were also reported by Chudley et al. (1984), Herbst et al. (1981), Hagerman et al. (1985), Borghgraef et al. (1987) and Theobald et al. (1987). However, with the exception of Theobald et al. (1987), no study on subtest analysis reported whether the differences mentioned were significant. In all these studies, lowest scores in Digit Span are men- 
tioned. This implies high distractibility, concentration difficulties and difficulties in short-term auditory sequential memory. Similar results have been reported by Howard-Peebles \& Stoddard (1979), Herbst et al. (1981), Madison et al. (1986a) and Dykens et al. (1987). Apart from this subtest, lowest scores were also mentioned for Information (Chudley et al. 1984), Coding (Borghgraef et al. 1987) and for Block Design and Similarities (Theobald et al. 1987). Hagerman et al. (1985) reported lowest scores for Arithmetic. Dykens et al. (1987) and Herbst et al. (1981) also mentioned poor performances on number concept and arithmetic skills. The results of the present study also suggest these relative weaknesses, although differences were not significant. The consistently low score in the subtest Arithmetic for the mentally retarded affected malles is relevant.

Cognitive strengths in the Wechsler profile were only mentioned by Chudley et al. (1984) and Borghgraef et al. (1987). Chudley et al. (1984) mentioned Simillarities, Picture Completion and Picture Arrangement. Borghgraef et al. (1987) mentioned Block Design and Object Assembly. Dykens et al. (1987) mentioned relative strength in simultaneous processing and Howard-Peebles \& Stoddard (1979) mentioned good performance in auditory reception and visual association. Our results are partly in accordance with these studies. Good performances were reached in Object Assembly and Picture Completion.

Looking at the cognitive strengths and weaknesses, results vary among studies. Interpretation of these results is difficult because of the use of different tests, analyzing techniques and sample differences. In the present study, for more than half of the patients no cognitive strengths and weaknesses could be ascertained. Patients showed a great variability in test scores, with the exception of consistently poor performances in Arith- metic. However, the patient with no mental retardation showed a relatively good performance in this subtest. From this study we can conclude that for the mildly and moderately retarded fragile $(X)$ patients, there seems to be a relative strength in perceptual organization, in contrast to poor verbal ability. We agree with Chudley et al. (1987) that many questions on the topic of cognitive variability in the fragile $\mathrm{X}$ syndrome remain unanswered. Based on the available data, no definitive conclusion can be reached on possible patterns and cognitive profiles in the fra $(X)$ syndrome. Paying attention to the broader spectrum of cognitive functions by systematic assessment of intelligence and specific cognitive skills like perception, memory and language is necessary. Future research should also concentrate on studying subgroups within the fra $(X)$ syndrome, e.g. differences in levels of mental retardation, developmental history and age.

\section{References}

Borghgraef, M., J. P. Fryms, A. Dielkens, K. Pyck \& H. Van den Berghe (1987). Fragile (X) syndrome: a study of the psychological profile in 23 prepubertal patients. Clin. Genet. 32 . $179-180$.

Bregman, J. D., E. Dykens, M. Watson, S. I. Ort \& J. F. Leckman (1987). Fragile-X syndrome: variability of phenotypic expression. J. Am. Acad. Child Adolesc. Psychiatry 36, 463-471

Chudley, A. E., A. Shepel, E. McGahey, J. Knoll \& J. W. Gerrard (1984), Behavioral phenotype. Am. J. Med. Genet. 17, 45-50.

Chudley, A.E., R. de von Flindt \& R. J. Hagerman (1987). Cognitive variability in the fragile $X$ syndrome. Am. J. Med. Genet, 28, 13-15.

Curfs, L. M. G., G. A. J. Schreppers-Tijdink, A. Wiegers, M. Borghgraef \& J. P. Fryns (1988). Intelligence and psychological profile in the fra $(X)$ syndrome: a longitudinal study in 20 fra(X) boys. J. Med. Genet., accepted for publication.

Daker, M. G., P. Chidiac, C. N. Fear \& A. C. Berry (1981). Fragile $X$ in a normal male: a cautionary tale. Lancet $\mathbf{i}, 780$.

Daker, M. G., P. Chidiac, C. N. Fear \& A. C. Berry 
(1982). Fragile $X$ in brothers with normal intelligence, or the man who might have been a genius. J. Med. Genet 19,64.

Dielkens, A. (1986). Het fragiele $X$ syndroom. Leuven, Caholic University, unpublished maniscript.

Dykens, E. M. R. M. Hodapp \& J. F. Leckman (1987). Strengths and weaknesses in the intellectual functioning of males with fragile $X$ syndrome. Am. J. Ment. Defic. 92, 234 236.

Dykens, E., J. Leckman, R. Paul \& M. Watson (1988). Cognitive, behavioral and adaptive functioning in fragile $X$ and non-fragile $X$ re-

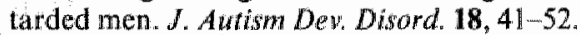

Eren, M. \& C. Disteche (1983). Behavioural phenotype of the fragile $X$ syndrome: relationship between frequency of marker $X$, mental retardation and verbal disability. Am. J. Hum. Genel. 35, I31A.

Fryns, J P. (1984). The lragile X syndrome: a study of 83 families. Chin. Genet 26, 497-528.

Goldfine, P. E., P. M. McPherson, V. A. Hardesty, G. A. Heath, L. J. Bauregard \& A. A. Baker (1987). Case report: fragile- $X$ syndrome associated with primary learning disability. $J$. Am. Acad. Child Adol Psychiatry 26, 589-592.

Haasen P. P. van, E. E. J. de Bruyn, Y. J. Pijl, Y. H. Poortinga, H. C. Lutje Spelberg, G. Vander Steene, P. Coetsier, R. Spoelders-Claes \& J. Stinissen (1986). Wechsler Intelligence Scale for Children-Revised. Nederlandstalige Uitgave. Lisse, Swets \& Zeitlinger.

Hagerman, R. J., M. Kemper \& M. Hudson (1985). Learning disabilities and attentional problems in boys with the fragile $X$ syndrome. Am. J. Dis. Child 139, 674678.

Herbst, D. S., H. G. Dunn, F. J. Dill, D. K. Kalousek \& L. W. Krywaniuk (1981). Further delineation of $\mathrm{X}$-linked mental retardation. Hum. Genet. 58, 366-372.

Howard-Peebles, P. N., G. R. Stoddand \& M. G. Mims (1979). Fumilial $X$-linked mental retardation, verbal disability, and marker $X$ chromosomes. Am. J. Hum. Gener. 31, 214-222.

Howard-Peebles, P. N. \& G. R. Stoddard (1979). $X$-linked mental retardation with macroorchidism and marker $X$ chromosome. Hum. Genet. $50,247-251$.

Lagae, C. \& L. Coetsier (1963). Wechster Intellgence Scale for Children (WISC). Handleiding bij de Aanpassing voor Vlaamse Kinderen. Gent, Rujksuniversiteit.

Madison, L. S., C. George \& J. B. Moeschler (1986a). Cognitive functioning in the fragile-X syndrome: a study of intellectual, memory and communication skills. J. Ment. Defic. Res. 30, $129-148$.
Madison, L. S., G. A. Mosher \& C. H. George (1986b). Fragile- $X$ syndrome: diagnosis and research. J. Pediatr. Psychol. 11, 91-102.

Nielsen, K. B., N. Tommerup, H. Pulsen \& $\mathrm{M}$. Mikkelsen (1981). X-linked retardation with fragile $X$. A pedigree showing transmission by apparently unaffected males and partial expression in female carriers. Hum. Genet. 59, 23.

Partington, M. W. (1984). The fragile $X$ syndrome II: preliminary data on growth and development in males. Am.J. Med. Genet. 17, 175-194.

Renier, W. O., D. F. C. M. Smeets, J. M. J. C. Scheres, T. W. J. Hustinx, C. F. C. Hulsmans, C. P. M. O. Ophey, A. J. A. M. Bomers \& F. J. M. Gabreëls (1983). The Martin-Bell syndrome: a psychological, logopaedic and cytogenetic study of two affected brothers. J. Ment. Defic. Res. 27, $51-59$.

Rhoads, F. A. (1984). Fragile-X syndrome in Hawaii. A summary of clinical experience. $A \mathrm{~m} . \mathrm{J}$. Med. Genet. 17, 209-214.

Sattler, J. M. (1982). Asseswment of Children's Intelligence and Special Abilities. Boston, Allyn and Bacon, Inc.

Sutherland, G. K.\& F. Hecht (1985). Fragile Sites on Human Chromosiomes. Niew York, Oxford Press

Theoballd, T. H. M. \& D. A. Hay (1982). Behavior correlations of the fragile $X$-syndrome. Paper presented at the Twelfth Annual Meeting of the Behavior Genetic Association, Fort Collins, $\mathrm{Co}$ lorado.

Theobald, T. H. M., D. A. Hay \& C. Judge (1987). Individual variation and specific cognitive deficits in the fra(X) syndrome. Am. J. Med. Genet. $28,1-11$.

Varley, C. K., V. A. Holm \& M. O. Eren (1985). Cognitive and psychiatric variability in 3 brothers with fragile X syndrome. J. Dev. Behav. Pediatr. 6, 87-90. .

Veenema, H., T. Veenema \& J. P. M. Geraedts (1987). The fragile $X$ syndrome in a large family II. Psychological investigations. J. Med. Genet. 24, 32-38.

Webb, G. C., J. G. Rogers, D. B. Pitt, J. Halliday \& $T$. Theobald (1981). Transmission of fragile (X) (q27) site from a male. Lancet i, 1231

Wechsler, D. (1974). Manual for the Wechsler Intelligence Scale for Children - Revised. New York, Psychological Corporation.

Address:

J. P. Fryms

Centre for Human Genetics

Herestraat 49

B-3000 Leuven

Belgitm 
2e. RELATIONSHIP BETWEEN AGE AND IQ AMONG FRAGILE $X$ MALES: A MULTICENTER STUDY 



\section{Relationship Between Age and IQ Among Fragile X Males: A Multicenter Study}

Gene S. Fisch, Tadao Arimami, Ursula Froster-Iskenius, Jean-Pierre Fryns, L.M. Curfs, M. Borghgraef, Patricia N. Howard-Peebles, Charles E. Schwartz, Richand J. Simensen, and Lawrence R. Shapiro

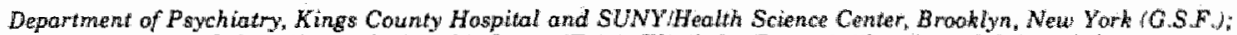

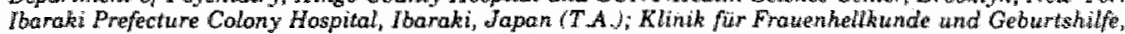
Medizinische Universitöit zu Lubeck, Lubeck. Feuteral Republic of Germany U.F. I. Center for Humar Genetics, Lewoen, Belgium (J.P.F., L.M.C.M.B.); Geneties and NVF Institute, Fairfax, and Medical College of Virginia,

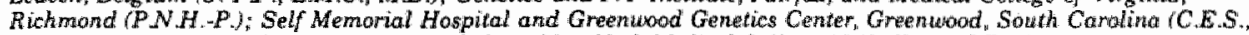
R.J.S., Department of Pediatrics and Pathology, New Yark Medilal College, Valhalla, and Regrional Medical Genetic Serthces and Labonatory, Thiells, New York (L.R.S.)

Longitudinal decline in $I Q$ among fragile $X$ males was reported recently. However, there are problems in retesting $1 \mathrm{Q}$ that may affect scores. Two such factors are intertest time in terval and score obtained on the first test. To determine the generality of IQ score changes, we examined 101 fragile $\mathbf{X}$ males from 6 centers. To ensure high test-retest reliabllity, only results from Stanford-Binet and Wechsler tests were used. Thus there were retest scores from 60 subjects. Test-retest reliability between first and last scores was very good $(r=0.85)$ and comparable to those seen in nonfragile $X$ mentally retarded individuals. Also computed were $\mathrm{z}$-scores of differences in $1 \mathrm{Q}$ scores. The $z$-score differences were distributed about mean at ISD below the expected zero value. Eighteen subjects showed statis. tically significant decreases in $1 Q, 6$ showed statistically significant increases, whill 5 showed the same scores. Z-score diffarences were not correlated with type of residence or elapsed intertest interval, but were negatively correlated with first score obtalned, indicat. ing regression-to-the-mean effect. Using a multiple regression analysis, we found first score obtained, age tested. and age retested signifficant predictors of score differencas counting for $19 \%$ of the total variance. These results suggest that factors previously identified as affecting retest scores have a smaller effect than originally thought. It is suspected that decline in $1 Q$ is associated with dymamic neurological processes and needs to be investigated further.

Received for publication August 1, 1989, Revibion Received De. ceitiber $7,1989$.

Address reprint requests to Gene S. Fisch. Ph.D., Diwision of Child/Adolescent Puychiatry Kings Coumiy Hospiten, d51 Clarkson Ave., Brooklym. NY 11203 .
KEY WORDS: neurological processes, longlthidinal decrease regression. analysis

\section{INTRODUCTION}

Fragile $X$ (fra [X]) syndrome is the second most common causally defined abnormality found among men. tally retarded (MR) individuals, As masured by $1 Q$ intelligence in most melles with fra $\mathrm{X}$ ) is below 501 (Sutherland and Hecht, 1985$]$. Among fra( $X)$ males, $[Q$ is correlated with several factors: It is negatively corre lated with frequency of fra $X$ expression . Chudley et al., 1983i], although other investigators have reported no correlution [Turner and Jacobs, 1983; Prouty et al., 1988]. In cross-sectional studies, age was negatively correlated with IQ IFryns and wan den Berghe, 1983 ; Chudley et al., 1983, Hagerman et al., 1983; Brondum Nielsen, 1983; Partington, 1984; Borghgraef et al., 1987; Prouty et al., 1988].

However, as Sutherland and Hecht [1985] noted, the obgerved correlation of 19 with age may have been bi. ased by factors not directly assoicated with the gyndrome itself. For example, these authors that the current cohort of younger males may have been exposed to stimulation programs and at an earlier age than older males. In addition older males wore more likely to has we been institutionalized.

Earlier, Hagerman al. [1983) noted longitudinal declines in 4 fra $(X)$ males. Subsequenty, Lachiewict et al. [1987] retrospectively oxamimed 21 noningtitu tionalized $\mathrm{fra}(X)$ males to assess whether their $1 \mathrm{G}$ had charnged over time. Using several different standardized tests, these researchers noted that $1 Q$ decreased signifi. cantly in 13 individwals. Dyken et al $\mid 1989$ also stud. ied 10 noninstitutionalized fra $(X)$ males longitudinally using several different tests and observed that individual IQ scoress significantly decreased across 3 age intervals. In addition, they not d that abjects wh higher $I Q Q$ scores in the earliest period showed the greatest lasses at 
gutseguent tert intervals. Uming the Stanford-Bnet ais the sole measure of liq, Hagerman et al [1989] tegted 24

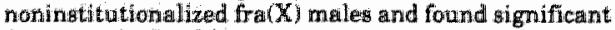
decreases in 7 subjects.

It should be noted that there are problems associated with recurrent 19 testing of individual gubjets. Sattler [1988] observed that results of repeated evaluations may be diffeull to interpret for several reasons. Practice (or retest) effecti are not easily differentiated from changes in clinical functioning; the length of time elapsed between tests affects retest scores; the magnitude of the change in the retest score may vary as a function of the score of the first test (a regression-to-themean effect) diferent terts that pirtatively measure the same abilities may yiald scores that are not comparable. With these difficultes in mind, the purpose of this study was to examine longludinal changes in TQ experienced by fra( $X)$ males residing in varions facilities around the worla.

\section{MATERIALS AND METHODS Subjects}

The subjects in this study were 101 males from 6 centers:

1. 23 from Department of Pediatrics and Pathology. New York Medical College, Valhalla, New York, and the Regional Medical Genetic Services and Laboratory. Thiells, New York

2. 21 from the Family Practice Center, Self Memorial Hospital, and the Department of Medical Genetics; Greenwood Genetics Center, Greenwow, South Carom lina

3. 19 from the Center for Human Genetics, Lewven, Belgiurn

4. 17 from the Ibaraki Prefectural Colony Hospital, Ibaraki, Japan

5. 13 from the Postnatal Laboratory, Genetics and IVF Institute, Fairfax, Virginïa

6. 8 from the Mediainische Universitat zu Lubeck. Lubeck, Federal Republic of Germany

Their ages ranged from 4 to 73 years. Thirty four (34\%) resided at home, 17 (17\%) lived at a residential treatment fachlity or center (RTF), and the remaining 50 (50\%) were institutionalized. Of those subjects who provided information rezarding educational andior stiman lation programs (n $=66), 19(29 \%)$, were not in any program, while 47 (71\%) were. For 37 of those entrolled in guch programs, the time of enrollment ranged from 1 to 2.1. years, with mean enrol ment time of 6.7 years. of those providing information on employment $(n=69), 60$ $(97 \%)$ were ther not omployed or worked in sheltered workshops. Primary dilignoses were as follows: 95 (95\%) were $M R, 4(4 \%)$ were learning disabled (LD), 1 was autistice, and 1 was normal.

\section{Procedure}

All subjects bad been administered at least one $1 Q$ test: 70 subjects were given the Straford-Binet (SB; $69 \%$; 19 were given one of the Wechsler tests (WISC or
WISC-R, WAIS or WAIS-R. WPPSI ar WPPSI-R); 12 were given other avallable standardized tests (e.g., Slogsen Intelligence Test, Cattelly. The subjects' ages at first administration ranged from $2^{1 / 2}$ to $53^{1 / 2}$ years.

To ensure high test-retest reliability, only the results from the SB and Wechsler tests were wsed for longitudinal and ysis. Consequently, there were 60 subjects who had been tested using an SB or Wechsier and then re-examined using the same or a similar test. That is, 46 of 47 subjects administered the $\mathrm{SB}$ were retested with the SB. The exception was one subject who was first. evaluated with the $S B$ (4th dition [FE]) and then retested using the the WISC-R. (Satiler [1988) states that the 2 tests are comparable, and reliability between scores obtained on the SBFE and WISC-R is extremely good.) The remaining 13 subjects were initally tested with one of the Wechs!er tests and then retested using either the same or another Wechsler. The Wechsler tests are comparable to one another in design and reliability [Sattler, 1988]. The intertest interwal (ITI) ranged from 2 months to $291 / 2$ years. Where multiple tests were administered to an individuail, either the most recent. score or the score from the mast recent "like" test was used.

Retested subjects: ages ranged from 4 to 73 years. Primary diagnoses of retested subjects were as follows: $56(93 \%)$ subjects were $\mathrm{MR}_{\mathrm{n}} 3(5 \%)$ were $\mathrm{LD}$, and 1 was antistic. Nineteen individuals $(32 \%)$ resided at home 12 $(20 \%)$ were from RTFs, and 29 (48\%) were from instituthons.

\section{FESULTS}

The IQ scores of subjects tested at least once $(n=1.01$ ) ranged from 14 to 114 , with a mean $I Q=39.2( \pm 19.0)$. For those subjects who were tested and retested using the SB or Wechslers ( $\mathrm{n}=60$ ), initial $1 \mathrm{Q}$ scores ranged from 14 to 93 , with a mean $\mathbb{I Q}=40.1( \pm 17.7)$, while $I Q$ scores for the last test administered ranged from 14 to 73 , with a mean $\mathrm{lQ}=35.8( \pm 16.4)$. A comparison of first and last scores for those tested more than once is shown in the "sliding square plot" in Figure $\mathbb{I}$.

The large square shown contains ordered pairs of $1 \mathrm{Q}$ scores, where the horizontal and vertical axes represent the first and last. IQ scores, respectively. Points projected to the east (right) create a boxplot [Tukey, 1977] of last IQ scores; points to the morth (top) create a boxplot of first IQ scores. The boxplot generates 5 summary scores of interest: the median score for the group (the center line in the box); the first and third quartilles, (the ends of the baxi; and extreme scores (the "whiskers"). Points projected to the southwest along the diagonal to the scaterplot are individual subjects" paired difference scores (last score minus first score). Explloratory plots for paired data were developed by Rosenbaum [1981, 1989]. Multiple projections hike these allow examination of paired data from several perspectives. The dilagonal baxand whisker plot leads to the following observations: Since the upper quartile score is $0,50 \%$ of retested subjects had last $1 Q$ scores between 0 and 9 points below their first $1 Q$ scores. It also indicates that one extreme, one subject obtained a last score that was 32 points lower than that frst attained. At the other ex- 


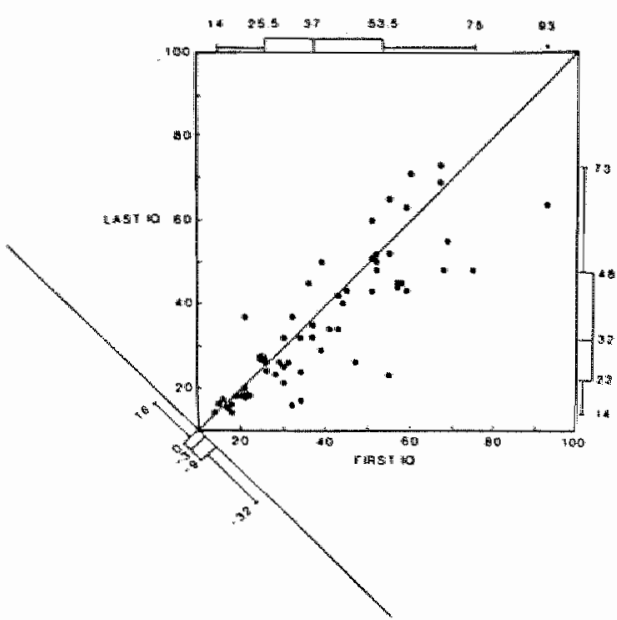

Figk 1. Bivariate plot of first and last $T Q$ scares of subjects tested and relested with the Stanford-Biniet or Wechsler tests in $m$.60

treme, one subject scored 16 points higher than that first attained.

On closer examination of the box-and-whisker plots for first and last test scores, the 2 groups appear to be quite similar to one another. In fact, the data in the scatterplot were used to determine the test-retest reliability between tirst and last scores. The Pearson prod. uct-moment correlation coefficient between these scores was computed and $\mathrm{r}=0.85(P<<0.01)$.

We also examined first and last scores and the ages at which each was acmimistered. These data are presented in Figures 2 and 3 . They represent crossisectional data for subjects tested at least once (Fig. $2 ; n=101$ ) and subjects tested more than once using any standardized test (Fig. $3 ; n=73$ ). We computed Pearson correlation coefficients and found a ignificant negative relation. ship between age and $1 Q$ i $r=-0.46, P^{\prime}<0.01$ for both first and last scores with age). However, a closer exam. ination of the data revealed that the best-fitting functions were curvilinear rather than linear. When the data were trensformed by reciprocal log functions, the correlation coefficient between $1 \mathrm{Q}$ score and age was consuderably strengthened $(r=0.57, P<0.01$ for both first and last scores with age).

We also examined the difference in 19 scores for each retested subject. The difference score ( $z_{\text {diff }}$ ) was obtained in the manner previously described by Lachiewicz al. [1987] and Hagerman et al. [1989]. These results are presented in Tablle 1. The mean $z_{\text {dir }}$ for the group - 1.11. Forty males (67\%) showed a decrease in $1 \mathrm{Q}, 15$ (25\%) showed an increase, while 5 (8\%) showed no change. Of those demonstrating a decrease in 10,18 $(45 \%)$ showed a sigmificant decline, whereas, of those

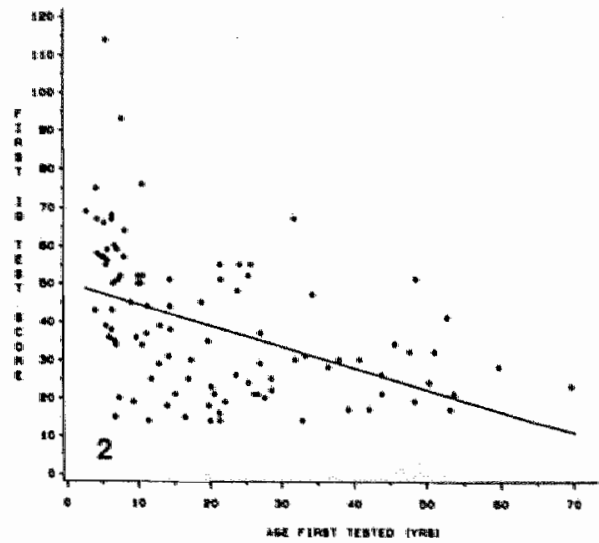

Fig. 2. Crons-sectional plot wo first le seores with age for aubjects teated at least once $\left(\mathrm{N}^{\prime}=1011\right.$.

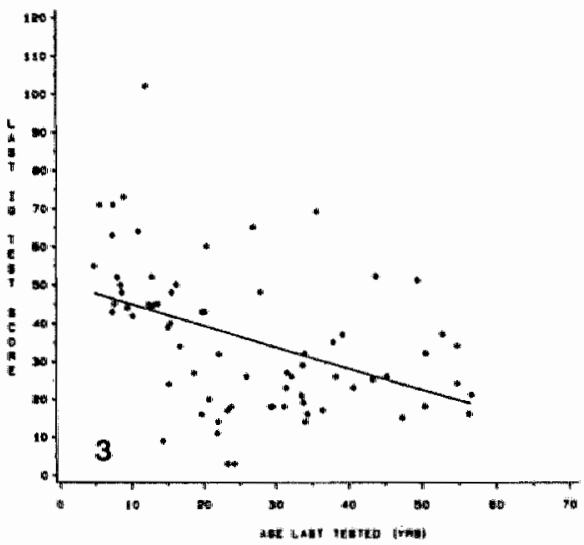

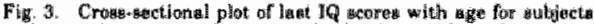
Lested mere than once with any windardized testh iN $=73$ !

demonstrating an increase in $1 \mathrm{Q}, 6$ (40\%) showed a sig. nificant increase. A frequency distribution of grouped $z_{\text {muff }}$ scores rounded to the nearest integer is presented in Figure: 4.

Also plotted in Figure 4 are the pected frequencies of $z_{d i f}$ that are normally (actually binomially) distributed. These data illustrate that the distribution of obHanned scores is similiar to that which was expected, albeit shifted lower by one standard score. In fact, the distribution of obtalued $z_{d i f}$ scores is not ig ignificantly 


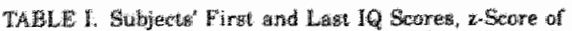
Tent Diffurenees, and Ages Whin First and Laugt Teste Were

\begin{tabular}{|c|c|c|c|c|c|}
\hline Sulbject & $\begin{array}{l}\text { Age } \\
\text { first: } \\
\text { tursed } \\
\text { tusbed }\end{array}$ & $\begin{array}{c}\text { Akge } \\
\text { latiot } \\
\text { tergited }\end{array}$ & $\begin{array}{l}\text { First } \\
19 \\
\text { seore }\end{array}$ & $\begin{array}{l}\text { Lat sat } \\
1 Q \\
\text { Bcore }\end{array}$ & $x_{\text {dist }}$ \\
\hline 1 & 80,98 & 56.28 & 32 & 116 & -4.72 \\
\hline 2 & 13.02 & 33.68 & 39 & 29 & -2.71 \\
\hline 3 & 53.65 & 56.68 & 21 & 21 & 000 \\
\hline 4 & 31.82 & 33.51 & 30 & 21 & -2.65 \\
\hline 5 & 2127 & 26.78 & 55 & 65 & 2.36 \\
\hline 6 & 16.97 & 18.61 & 25 & 27 & 0.59 \\
\hline 7 & 31.62 & 35.59 & 67 & 69 & 0.47 \\
\hline$s$ & 23.56 & 25.92 & 26 & 26 & 000 \\
\hline 5 & 5267 : & 54.71 & 41 & 34 & -2.06 \\
\hline 10 & 26.96 & 3213 & 29 & 26 & -0.88 \\
\hline 11 & 48.61 & 50.53 & 34 & 32 & -0.59 \\
\hline 12 & 37.92 & 43.31 & 30 & 25 & -1.47 \\
\hline 13 & 36.46 & 40.82 & 28 & 23 & -1.47 \\
\hline 14 & 43.80 & 50.41 & 21 & 18 & -0.88 \\
\hline 15 & 16.48 & 19.62 & 15 & 16 & 0.29 \\
\hline 16 & 17.34 & 33.99 & 30 & 32 & 0.59 \\
\hline 17 & 400 & 8.67 & 75 & 48 & -49 \\
\hline 18 & $B, 45$ & 0.04 & 55 & 52 & -0.72 \\
\hline 19 & 3.95 & 10.12 & 43 & 42 & -0.18 \\
\hline 20 & 11.13 & 22.14 & $3 \pi$ & 32 & -1.36 \\
\hline 21 & 6.34 & 16,67 & 49 & 34 & -24 \\
\hline 22 & 20.62 & 1279 & 32 & 52 & 0.00 \\
\hline 23 & 11.23 & 15.34 & 44 & 40 & -0.96 \\
\hline 24 & 4.12 & 8.87 & 67 & 73 & 1.06 \\
\hline 25 & 5.21 & 9.38 & 57 & 44 & -2.30 \\
\hline 26 & 6.27 & 15.53 & 68 & 48 & -4.81 \\
\hline 27 & 4,22 & 7.63 & 58 & 45 & -2.30 \\
\hline 28 & 5.47 & 8.47 & 39 & 50 & 1.95 \\
\hline 29 & 26.71 & 29.66 & 21 & 18 & -0.88 \\
\hline 30 & 19.73 & 34.07 & 18 & 14 & -1.18 \\
\hline 31 & 15.97 & 34.33 & 18 & 16 & -0.54 \\
\hline 32 & 28.57 & 31.14 & 22 & 18 & -1.18 \\
\hline 33 & $6.90^{\circ}$ & 36.43 & 34 & 17 & -4.61 \\
\hline 34 & 39.16 & 47.38 & 17 & 15 & -0.59 \\
\hline 35 & 49.72 & 54.74 & 26 & 24 & -0.89 \\
\hline 36 & 26112 & 39,13 & 21 & 37 & 4.72 \\
\hline 37 & 18.68 & 19.68 & 45 & 43 & -0.56 \\
\hline 38 & 21.22 & 23.22 & 16 & 17 & 0.29 \\
\hline 39 & 19.95 & 21.95 & 14 & 14 & 0.00 \\
\hline 40 & 47.72 & 521.72 & 32 & 37 & 1.47 \\
\hline 41 & 33,23 & 45.24 & 31 & 26 & -1.47 \\
\hline 42 & 48.42 & 49.42 & 51 & 51 & 0.00 \\
\hline 43 & 7.02 & 7,31 & 59 & 63 & 0.94 \\
\hline 44 & 34.24 & 38.24 & 47 & 26 & -6.19 \\
\hline 45 & 9.77 & 12.34 & 36 & 45 & 2.27 \\
\hline 46 & 665 & 7.34 & 60 & 71 & 2,59 \\
\hline 47 & 7.66 & 10.91 & 93 & 164 & $\begin{array}{r}-7.32 \\
\end{array}$ \\
\hline 48 & 0.96 & 19.19 & 57 & 45 & -3.09 \\
\hline 4 & 25.61 & 31.42 & 55 & 23 & -9.44 \\
\hline 50 & 2201 & 23.75 & 19 & 18 & -0.29 \\
\hline 31 & 20.56 & 2069 & 21 & 20 & -0.29 \\
\hline 52 & 28.52 & 31.51 & 25 & 27 & 0.59 \\
\hline 83 & 27.03 & 37.85 & 37 & 3.5 & -0.59 \\
\hline 54 & 25.27 & 27.81 & 52 & 48 & -112 \\
\hline 85 & 567 & 7.30 & 50 & 43 & -404 \\
\hline 56 & 10.58 & 15.19 & 34. & 24 & -2.71 \\
\hline 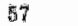 & 14.36 & 20.36 & 51 & 60 & 2.30 \\
\hline 86 & 2.62 & 4.83 & 69 & .55 & -2.48 \\
\hline 89 & 10.01 & 16.17 & 52 & 50 & $-0,47$ \\
\hline 60 & 0.21 & 20.09 & 51 & 43 & -2.17 \\
\hline
\end{tabular}

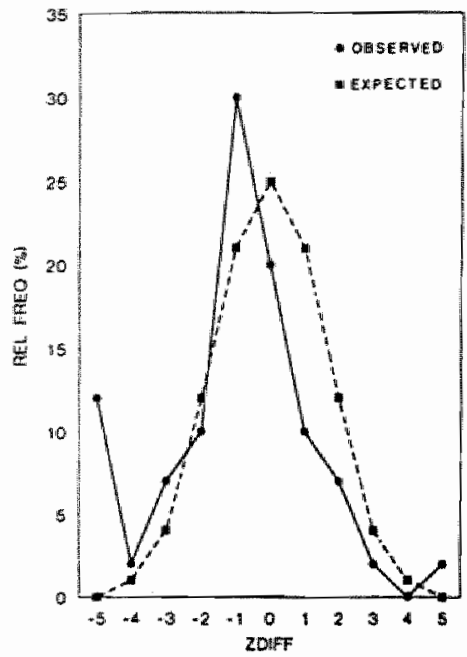

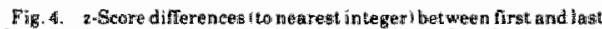

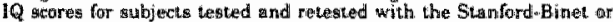
Whather:

different from the normal (Kolmogarov-Smirnov test statistic $=\mathbb{1} .09, P>0.18$ l.

We examined the type of residence (institution, RTF $;$ RTC, or home with parents) to determine if it was rem lated to the difference score. To that end, we assigned $z_{\text {bif }}$ scores to ane of three categories: (1) retest IQ scores significantly lower than the first test ( $z_{\text {dirf }} \leq-2.0$ ); (2) retest scores significantly higher than the first test $\left(z_{\text {diff }} \geq 2.0\right.$; and $(3) z_{\text {dif }}$ between -2.0 and +2.0 . Type of residence was crosstabulated with $x_{\text {uafr. }}$. The results are given in Table II and indicate no significant relationship (Mantel-Haenszel $X^{2}=0.71, P>0.39$ ).

We also examined $\mathrm{IT}$ Is and first $1 \mathrm{Q}$ scores to determine whether they were related to difference seores. These data are presented in Figures 5 and 6 . The results indicate that there is no relationship between $z_{\text {din }}$ and ITI $t=-0.19, P>0.31 \%$. On the other hand, $x_{\text {dir }}$ appears to be negatively (and significantly) correlated with the first IQ score $(r=-0.35, P<0.005$.

TABiLE II. Crosstabuliation of Type of Residence by zsis Seore

\begin{tabular}{|c|c|c|c|c|}
\hline \multirow[b]{2}{*}{ Resicience } & \multicolumn{3}{|c|}{$Z_{\text {watift }}$ score } & \multirow{2}{*}{$\begin{array}{l}\text { Row } \\
\text { total }\end{array}$} \\
\hline & $5-2,0$ & -2 to +2 & 20 & \\
\hline $\begin{array}{l}\text { At home } \\
\text { RTPlinTC } \\
\text { Institution } \\
\text { Columin } \\
\text { toutal }\end{array}$ & $\begin{array}{r}9 \\
2 \\
7 \\
18\end{array}$ & $\begin{array}{r}7 \\
9 \\
20 \\
36\end{array}$ & $\begin{array}{l}3 \\
1 \\
2 \\
6\end{array}$ & $\begin{array}{l}19 \\
12 \\
29 \\
60\end{array}$ \\
\hline
\end{tabular}




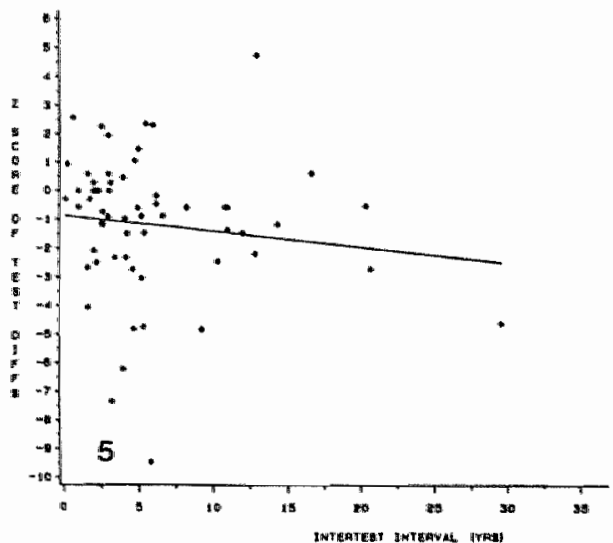

Fig. 5. 2.Scort differemces as a function of intertest änierval.

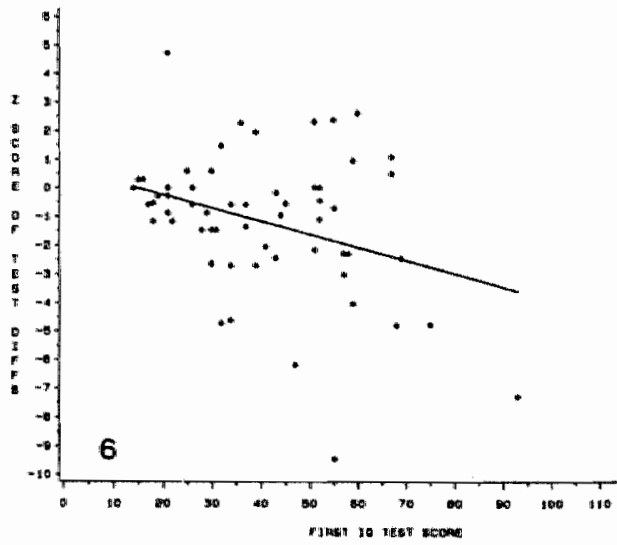

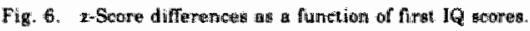

In an attempt to predict $z_{\text {dif }}$ scores, we applied a multiple regression analysis ISPSS-X REGRESSION; SPSS Inc., 1988] using $z_{\text {diff }}$ as the dependent measure with 4 of the previously described variables: age at which the first test was taken (using the reciprocal log transformation); age at which the last test was taken falso using the reciprocal log transformation); IT!; and 19 score first obtained. The results of the analysis indicated that, as previously noted, ITI was not a significant variable im the model. Subsequently, ITI was remowed from the analysis and the regression recomputed. The output is presented in Table III. The results indicate that each of

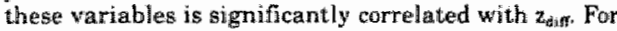

TABLE II. Multiple Remession A.rally of ind Scoris as a Function of First 12 Score, Reciprocal Loig of Aqe Fingt Tested, and Reciprowal Log of Age Last Tosied

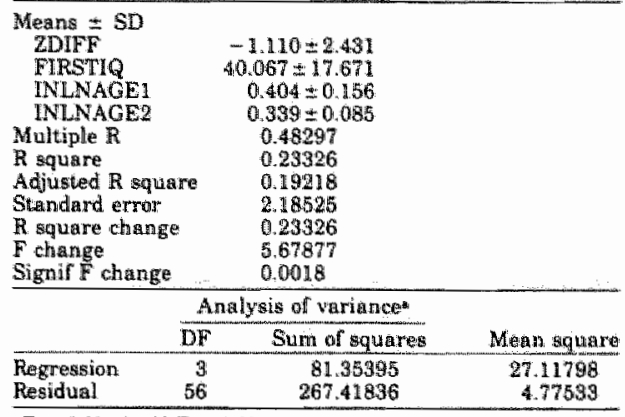

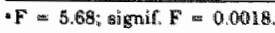

the multiple regression model, the adjusted coefficient of determination, $R^{2}=0.19$, which implies that these 3 predictor variables account tor $19 \%$ of the variance in

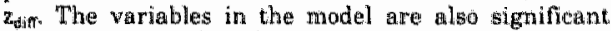
$(\mathrm{F}[3,56)=5.68, p<.002)$.

\section{DISCUSSION}

Cross-sectional results of this multicemter study demonstrate a significant negative relationship between 10 and age among fra $(X)$ males whether subjects were in. stitutionalized or note "These findings confirm results previously abtained by other investigators. However, the relationship between age and $I Q$ appears to be nonlinear and $1 \mathrm{Q}$ similar to one noted by Dykens et al. [1989].

Also as previously reported, there are longitudinal declines in $1 Q$ among individual fra( $X)$ males, a large proportion of which were statistically significant. Lachiewicz et all. [1987) reported decreases in IQ in early childhood, whereas Dykens ot al. [1989] noted stability and/or growth in IQ into late childhood or early adolescence. We found that amonig 18 subjects who showed significent longitudirad declines, one had been retested between $2^{1 / 2}$ and $51 / 2$ years of age, 6 were retested between 6 and $131 / 2$ years, and 11 were retested at age 14 years and older. In other words; wie obsorved sinnifi. cant declines at whatever age subjects had been retested.

Hagerman et al. 11989$]$ noted that $1 \mathrm{Q}$ tegts mersure different ablitives at different ages and that fra $(X)$ malles score better on performance tasks than abstract ones such as language. Satiler $(1974)$ indicated that for the SB form L-M, lamguage teists ochurred more fre. quently than other kinds of tests and at all age levels. However, languge itams oceur in approximately the same propertions of the whole test across all age levels. Specifically, at age level I (2 to 5 years), 26 of of the toest contained language items; at age level II (6 to 10 yearts. $20 \%$ and at age level 11] 111 to I6 yearst, $30 \%$. In contra. distinction, wisualmotor (performance) tasks wecount 
for a decreasing proportion of the best at levelis, II, and III (21\%, 10\%, and $0 \%$, respectively). Thus a decline in 10 scora may be explained in part by the changing conposition of the test itself acrosi different gge berels.

We found that for 17 eubjects who were administered

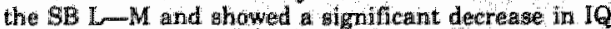
scores, 9 were tested across different age levels: I to II, II to III, or I to III. However 8 were tested at the same age levels and continuted to show significant decreases in acores. Wh thermore, differences in the composition of $1 \mathrm{Q}$ testlts across age levels will not account for intreases in scorer.

In 6 ind viduals, we found statiotically sugrificant increases in $1 Q$ scores. $A s$ whe sted earlier both in. creases and decreases can in part be accounted for by a regression-to-lhe-mean effect, since differences in the 10 z-Beores were negatively (and signifficantly) correlated with the first score obtained. Statistical regression accounts for higher retest scores when initial test scores are low with respect to the population mean and lower retest scores when initial scores are high [Sattler, 1988]. Although Sattler referred to the effect that occurs in 8 normal population with a moan 10 of 100 , regression is: always to the mesn of the group in question 1 Cook and Campbell, 1979]. That is, statistical regression may also arise in subpopulations where the mean $1 \mathrm{Q}$ is lower for higherl. To determine whother our sample mean $1 Q$ was representative of the fra(X) male population, we used the combined data from 21 studies presented in Suther. land and Hecht [1985]. We compered our sample mean $\mathrm{IQ}=39.2$ to their population grouped mean $\mathrm{IQ}=38.3$ and found no significant difference between them $i z=$ $0.06, P>0.48)$. Therefore, the regression-to-the-mean effect we observed is salient.

When difference scoreg were examined by multiple regression analysis, we found that age at first test, age at last test, and first test score were significant predictor variables. However, they only accounted for $19 \%$ of the adjusted variance, leaving more than $80 \%$ of the variance in the difference scores unexplained.

Previously, inwestigators found high test-retest reliability among MR individuals. Share et al. 196-4] found good reliability $(r=0.88$ ) among Down syndrome children who were retested 1 year after they were ini. thilly examined Using several standardized tests, Walker and Gross [1970] evaluated the stability of IQ gers among MP children and found no significart

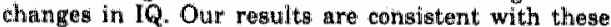
Indings. However, while the obtained difference scores were normally distributed, they wore distributed about. a mean 1 SD lower than expected.

Reported effectie of institutionalization on cogmitive and/or adaptive functioning among MR individuals have been variable. Sloan and Harmon [1947] noticed a decrease in $1 Q$ with ange whemeng Goodman [1976] and Hewitt et al. [1985] observed no correlation between age and mental deterioration. Among MR adults, Kleimberg wnd Galigan (1983) noted that deinstitutionalization into smaller community residences was associated with an tmprovement in adaptive behavior, but Ballat et al. $|1974|$ dowmented increases in $1 Q$ and cognitive development among institutionalized individuals. We found that sigmificant decreases in 19 scores were not corre. lated with type of residence. Therefore, institutionalization as wheh should not be expected to account adequately for declines in cogmitive function.

Reported effects of early intervention programs vary also. Sharaw and Shlomo [1986] found that a gradual decline in 19 amonge Down syndrome children was mit: gated by an infant stimulation program. Haskins et al. [1978] noted a greator increase in $1 \mathrm{Q}$ among $\mathrm{MR}$ preschool children enrolled in a stimulation program as compared with nonstimulated $M \mathrm{R}$ control individuals, but that group differences wanished by the time they entered the third grade. Aronson and Fallstrom [1977] found that a developmental training program had a rigmificant effect on the 10 of MR children. However, in a follow -up study 1 year later, these researchers observed that the positive effect had diminished. That is, training effects of educational/atimulation programs appear to be temporary.

In summary, type of residence, $1 Q$ test compasition, time elapsed between teating sessions, and education/ stimula tion programs appear to have either equivocal or norisignificant effects on $1 \mathrm{Q}$ scores whether scores show significant decreases or increases. Statistical regression partly accounts for both increases and decreases in 19 scores, but does not explain the distribution of difference *cores about a mean 1 SD below zero. As explanatory variables, regression-to-the-mean and age tested acconmit for less than $20 \%$ of the adjusted variance in the difference scores. These results strongly suggest that other factors are involved.

Sutherland and Hecht [1985] conjectured that the decline in $1 Q$ may be the consequence of progressive neurological dysfunction. Unfortumately, there have beer too few studies in this area. Finelli et al. $[1985]$ reported that 15 of 17 fra $(X)$ males presented with at least one abnormal neurological finding; Arinami et al. [1988] examined auditory brainstem responses in 12 fra $(X)$ males and found prolonged interpeak latencies as compared with controls" Cammarata et al. [1988] observed enlarged lateral ventricles and a large arachnoid cyst in the posterior fossa of 1 fra $(X)$ male; whereas Reiss [1988] found cerebellar hypoplasia in 4 fra(X) males. Although they also noted soft neurological signs, Vieregge and Froster-Iskenits [1989] found no specific neurological abnormality in 29 fra $(X)$ males. From the results obtained in our multicenter malysis, we suspect that much of the decline in $1 \mathrm{Q}$ is associated with a dynamic neurological process or processes that do not occur uni. formly in all fra( $X)$ individuals. This process or pro. cesses may be associated with progressive dysfunction as conjectured by Sutherland ard Hecht [1985] or result from cessation of normal neurological development. We suggest that the form and function of neturological pro. cesses associated with the fra(X) syndrome be investi. gated further. To that end, we will maintain an opera database to collect further information and additional subjects.

\section{ACKNOWLEDGMENTS}

We thank Eileen Lombardi, R.N "from Medical Genetics, Department of Pediatrics and Pathology, New 
York Medicall College, Walhalla, New York: Julie Smith, M.S. from the Regional Medical Genetic Services and Laboratory, Thiells, New York; Mary Wedgeworth and Dr. Paul Cotten. from the Mississippi Department of Mental Health; and Jane Dean, R.N., from the Greenmood Gemetics Center, Greenwood, South Carolina, for their assistance in collecting data. We also thank Miriam S. Grosof from Yeshiwa University for her many helpful comments and suggestions.

\section{REFERENCES}

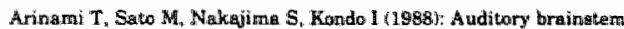
responses in the [ragile $X$ ayndrome. Am J Ham Genet $43.46-51$.

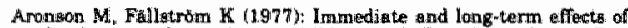
developmental triaining in chiduren wh Down's oyndrome. Dev Med Child Neurol 19:469-4944.

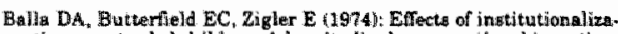

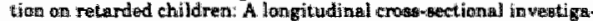
tion. Am J Ment Defle 78:5:30\%5.49.

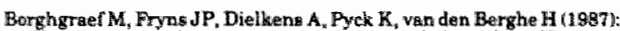
Fragilie ( $X$ syndrorre: A study of the psychological protile in 29 prepubertail patiente Clin Genet 32:179-186.

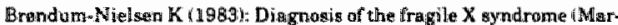

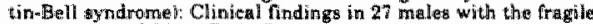
situ Xit X28. I Men' Defte Res 27:211-226.

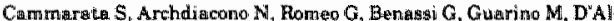
fesandro $R$ (1.988): Prevalencie of mental retardatjon related to fra the $X$ sinmdrome and other chromosomal abnormalitines in the Repubjie of San Marino. Dev Med Child Neurol 30:649-849.

Chudley AE, Kall J, Gerrard JW, Shepali L, MoGakey E, Anderson d

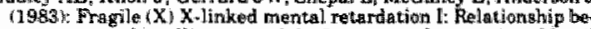
twen age and intelligence and the frequency of expiression of fragil (1) (q28). Am \ Med Genet 14:699-712,

Cook TD, Camplell DT (1979): "Quesi-Experimentation: Design and Anelysis Issues for Field Settings." Boston: Houghtom Mifnlän $\mathrm{Co}$ PP $52-53$

Dykens EM. Hodapp FM, Ort is, Finucane B, Shapira LR. Leckman JF i. 1989 : 'The trajectory of sojonitive development. in males with frag-

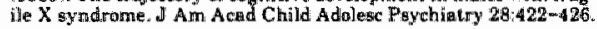

Finelli PF, Pueschel SM, Fadre- Mindoza T, O'Brien MM (1985) Neurological fundings in patients with the fragile- $X$ ayridtome. I Neurol Neurosirg Psychiatiry 48:150-153.

Fryng JPan den Berghe $H(1983): X$ linked mental retardation and Prafile $\left(X_{q} 27\right)$ situe Clin Genet $23 \times 203-206$.

Goodmun JP (1976) A ging and 19 change in institutionalized mentally retarded. Paychol Pep 39:999-1.006.

Hagerman Rd, Schreiner RA, Kemper MB, Wittenberger MD, Zahn B.

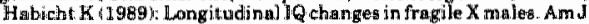
Med Grenet $33: 513 \rightarrow 518$.

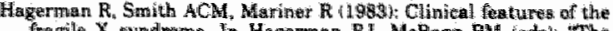

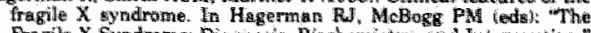

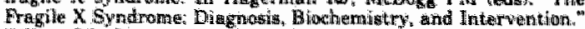

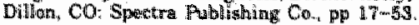

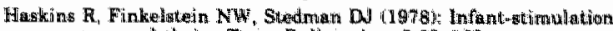

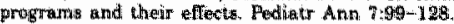

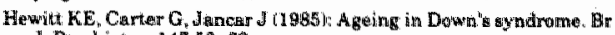
H Pychistiry $147.58-62$.

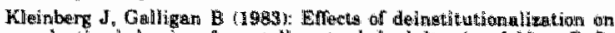
maptive behavior of mentally metarded adulits. Am a Ment Defic $88.21-2$.

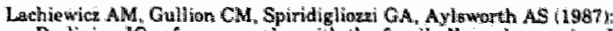

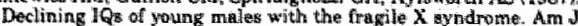
Thent Returd 92.272-979.

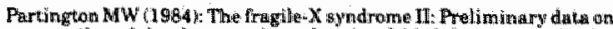

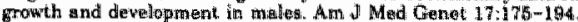

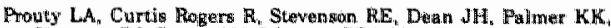

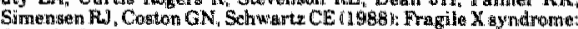
Growth, development, and intellectual function. An 3 Mad Genet $30: 129-142$.

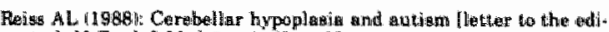
tar]. N Engl I Mad $319: 1152-1133$.

Roganbaum PR (1981) The two scale plot: An explotacory diaplay of

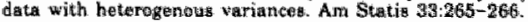

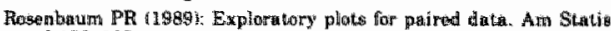
$43: 90: 109$

Satther JM 11974): "Assessment of Childiren" Intelvgerne" Phila"

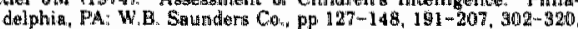
441 .

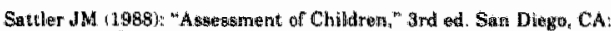
J.M. Sattler, pp 245i-29.2, $531-542$.

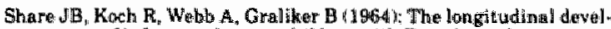
opment of infonis and young whildren with Down's youdrome (mon

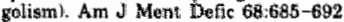

Sharav T. Shlomo L 11986 : Stimnilation of infants with Daws gym. dirome: Longuterm effectic Ment Retand 24:81-86.

Slom W, Harmon HF C1947 Constancy of 1.9 in mental defectives, Genet Prychol 71:17\%-185.

SPGS Jne 1988t: "SPSS-X User" Guide," Jrd ad. New York: MeGrawHill Book Co., pp 6e3-64t.

Sutherland GR, Hecht $\mathbf{F} 1$ 1985: "Fragile Sites on Human Chromow sames." Niew York: Oxford Univerbity Press." Pp 113-131.

Tukey WW (1977): "Exploritory Data Analysis." Pheading MA Addiaon. Wheldey Publ. Co. pp $27-6$.

Turner $G$ Jacobs $P$ (198is: Marker ( $X$ Winked mental returdation. In

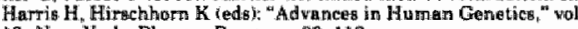
13. New York: Plenum Prests, Pp 83-112.

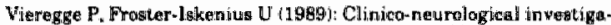
tions in the fra $X$ ? form of mental recardiation. I Net rol 236:86-92.

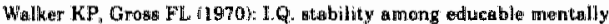

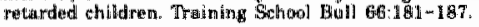


2f. THE FEMALE AND THE FRAGILE $X$ SYNDROME. DATA ON CLINICAL AND PSYCHOLOGICAL FINDINGS IN 7 FRA $(X)$ CARRIERS 



\title{
The female and the fragile $X$ syndrome: data on clinical and psychological findings in $7 \mathrm{fra}(X)$ carriers
}

\author{
M. Borghgraff, J. P. Fryns and H. van den Berghrs \\ Centre for Human Genetics, University of Leuven, Beigium
}

\begin{abstract}
In this report we present precise data on the clinical, intellectual and behavioural findings in 7 young fra(X) positive girls. The two most common and most imporlant findings are an overgrowth syndrome present from birth on and common behavioural features like severe attentional problems and extreme shyness and anxiety. These symptoms seem to constitute the major criteria for fra $(X)$ screening in prepubertal girls. The findings in prewious studies are compared with the present observations.
\end{abstract}

Received 20 June, revised 7 Novenber, accepted for publication 12 Nowember 1989

Key words: behaviour; female heterozygotes; fra $(X)$ syndrome; intelligence

During the past few years, the fra $(X)$ syndrome has been the subject of widespread medical interest and, more particularly, the clinical, psychological and cytogenetic findings in the fra $(X)$ male have progressively been elucidated and delineated (Sutherland 1979, Mattei et al. 1981, Jacobs et al. 1983, Brendum-Nielsen 1983, Opitz \& Sutherland 1984, Sherman et ul. 1983, Fryns 1984, Fryns et al. 1984).

In the same period, data were reported on obligate female carriers and they confirm the difficult and puzzling problem of female patients with the $\mathrm{fra}(\mathrm{X})$ syndrome, i.e. in more than $30 \%$ of the obligate carriers mental development was found to be subnormal and partial clinical manifestations were also present in some $28 \%$ of them (Hagerman \& Smith 1983, Fryns 1986, Sherman et al. 1985).

Further precise data on the clinical and psychological findings are of great importance for early diagnosis and detection of female carriers and for a better delineation of selection criteria for $f r a(X)$ screening in the female.

In the present paper we describe the findings in 7 young $\mathrm{fra}(X)$ positive females.

\section{Materials and Methods}

During recent years a positive fragile $X$ screening, with a percentage of fra $(X)$ positive cells varying from 2 to $30 \%$, was found in 7 females aged between $6 \frac{5}{12}$ years and 13 years (see Table 1). In all patients two fra(X) screenings were performed with 1 to 2 months interval in at least 100 metaphases of M 199 peripheral blood Jymphocyte cultures, and the presence of fragile $X$ chromosome was confirmed with $\mathrm{G}$-banding techniques.

Patients 1 and 4 are index patients in their families. They were selected for fra $(X)$ screening because of the clinical suspicion of fra(X) syndrome.

Patients 2,3,5, 6 and 7 were detected at cytogenetic screening in their families after 
the diagnosis of fra $(X)$ syndrome in their maternal cousins (Patients 2 and 3 ) or in their brothers (Patients 5,6 and 7).

In addition to careful clinical examination, IQ testing (Terman \& Merrill 1973, Wechster 1974) and behavioural observations, with the help of checklists together with parents and teachers, were performed in all patients.

\section{Results}

Table I summarizes the most important clinical and psychological data in the 7 fra(X) positive girls.

\section{Clinical Symptoms (Fig. I' and 2)}

In all patients stigmata, considered to be characteristic findings in $\operatorname{ra}(X)$ positive males, were found; i.e. pre- and postnatal overgrowth, macrocephaly, large ears and long face. In three patients (Patients 2, 3 and 4), a Sotos-like overgrowth syndrome with a general growth pattern above the 97th percentile was present. Macrocrania was present in Patient 1. Five patients ( $\mathrm{Pa}-$ tients $1,3,4,6,7)$ had a long face and $\mathrm{Pa}$ tients 2 and 5 had a full, round face. Large ears were present in two girls ( 4 and 6 ) and epileptic seizures were noted in Patient 1.

\section{Intellectual Development}

A widespread variation of IQ's was noted in these 7 girls. One girl (Patient 2) had moderate mental retardation (IQ 50), two others (Patients 6 and 7) were borderline mentally retarded (IQ's between 82 and 85 ),

Table 1

Clinical and behavioural characteristics in the 7 tra(X) positive females

\begin{tabular}{|c|c|c|c|c|c|c|}
\hline $\begin{array}{l}\text { Number } \\
\text { of } \\
\text { patient }\end{array}$ & $\begin{array}{l}\text { Age } \\
\text { (yealrs, } \\
\text { months) }\end{array}$ & $\begin{array}{l}\text { Relation } \\
\text { to piroband }\end{array}$ & $\begin{array}{l}\% \text { frax } \\
\text { positive } \\
\text { cells }\end{array}$ & 10 & Physical features & $\begin{array}{l}\text { Biehavioural } \\
\text { characteristics }\end{array}$ \\
\hline 1. B.K. & 6 & index patient & $2 \%$ & $\begin{array}{l}90 \\
(T M)\end{array}$ & $\begin{array}{l}\text { long face, seizure disorder, } \\
\text { growth: length > P97, head } \\
\text { circumference: P75 }\end{array}$ & $\begin{array}{l}\text { attentional problems, ex- } \\
\text { cessive anxiety, shy, social } \\
\text { withdrawai. ADHD }\end{array}$ \\
\hline 2. M.G. & 6,8 & cousin" & 10 & $\begin{array}{l}50 \\
(\mathrm{TM})\end{array}$ & $\begin{array}{l}\text { full, round face, growth: } \\
\text { length } P 50 \text {, head circumfer- } \\
\text { ence } P 97\end{array}$ & $\begin{array}{l}\text { ADHD, psychotic behavi- } \\
\text { our, poor eye contact, so- } \\
\text { cial withdrawal, handflap- } \\
\text { ping }\end{array}$ \\
\hline 3. M.I. & $7 \frac{1}{48}$ & cousin" & 18 & $\begin{array}{l}135 \\
(T M)\end{array}$ & $\begin{array}{l}\text { long face, growth: length } \\
\text { P27, head circumference } \\
\text { P97 }\end{array}$ & $\begin{array}{l}\text { attentional problems, over- } \\
\text { acting, excited inappropri- } \\
\text { ate speech }\end{array}$ \\
\hline 4. C.S. & 8 & index patient & 8 & $\begin{array}{c}85 \\
(W \| S C R)\end{array}$ & $\begin{array}{l}\text { long tace, growth length } \\
\text { P75, head circumference } \\
\text { Pg7 }\end{array}$ & $\begin{array}{l}\text { shy, social withdrawal, ex- } \\
\text { cessive anxiety, attentional } \\
\text { problems, handflapping }\end{array}$ \\
\hline 5. GK & 9 & Sistor & 12 & $\begin{array}{c}110 \\
\text { (WISCR) }\end{array}$ & $\begin{array}{l}\text { full, round face, length and } \\
\text { head circumference above } \\
\text { P97 }\end{array}$ & $\begin{array}{l}\text { shy, social withdrawal, } \\
\text { anxious, attentional prob- } \\
\text { lems. }\end{array}$ \\
\hline 6. Vo. & 10 & sister & 2 & $\begin{array}{c}82 \\
\text { (WISCR) }\end{array}$ & $\begin{array}{l}\text { long face, length at } P 75 \text {, } \\
\text { head circumference P97 }\end{array}$ & $\begin{array}{l}\text { shy, social withdrawal, } \\
\text { anxious, attentional prob- } \\
\text { lems }\end{array}$ \\
\hline 7. C.T. & 13 & sister & 30 & $\begin{array}{c}89 \\
\text { (WISCR) }\end{array}$ & $\begin{array}{l}\text { long face, length and head } \\
\text { circumference above P97 }\end{array}$ & $\begin{array}{l}\text { shy, social withdrawal, lim- } \\
\text { ited eye contact, attention } \\
\text { problems }\end{array}$ \\
\hline
\end{tabular}

" two sisters. TM = Torman-Merill: WISCR = Wechsier scale. 
Fig. 1. Patient 4 at 14 months of age.

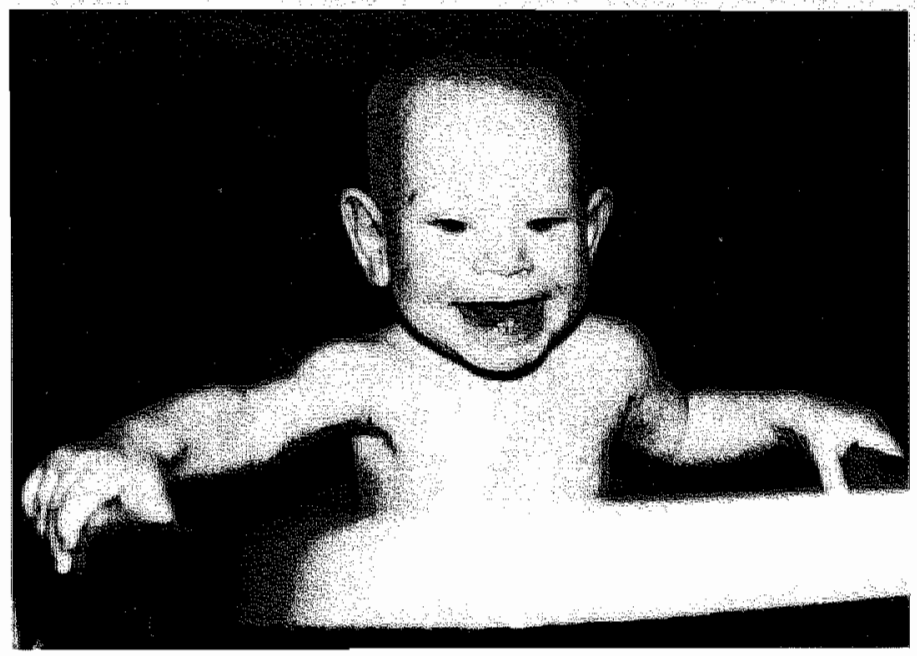

two (Patients 1 and 7) were functioning at a low normal level (IQ's 89-90) and two (Patients 3 and 5) had normal intelligence (IQ's 110 and 135). The mean IQ for this group was 91.7. Comparison of the subtest scores did not reveal any consistent profile of strengths and weaknesses in this group. The mean subtest scores on the Wechsler scale (Patients 4, 5, 6 and 7) were: information 7 , similarities 7 , arithmetic 10 , vocabulary 7 , comprehension 7 on the verbal scalle and picture completion 9, picture arrangement 6 , block design 7 , object assembly 7 and coding 9 on the performance scale. Data on verbal and performance intelligence indicated only small discrepancies between verbal and performance IQ (mean verbal IQ 90; mean performance IQ 85).

\section{Behavioural Characteristics}

A mild to moderate Attention Deficit Disorder was observed in all 7 girls. They experienced great difficulties in concentrating on a specific object. They mostly could not finish a task within the expected time limits and we observed poor topic maintenance in their speech. The two youngest girls also showed obvious hyperactivity (ADHD). They could not sit for a long time and were always running and busy. Nervous body movements and inappropriate laughter or giggling were observed in both of them. The highest functioning $\mathrm{fra}(X)$ girl demon-

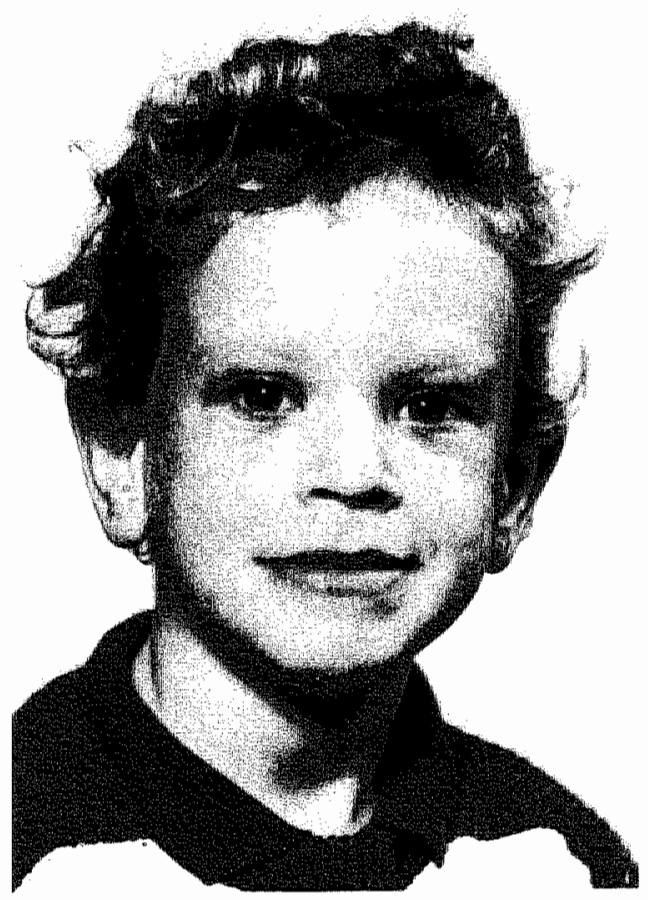

Fig. 2. Patient 4 at 7 years. 
strated some overacting and excited behaviour. She had periods of inappropriate speech and a run-on narrative style.

Five of the $7 \mathrm{fra}(\mathrm{X})$ girls were extremely shy, ayoided social interaction and had short and fugitive eye-contact. Four of them were very anxious and had great difficulties in adapting to a new situation or to changes in the environment. Handflapping, a typical behavioural feature in young fra( $\mathrm{X})$ boys, was seen in two girls (patients 1 and 4).

\section{Discussion}

From the observation made in the one pubertal and six prepubertal $\operatorname{fra}(\mathrm{X})$ positive girls, reported in the present paper, important conclusions can be drawn with regard to the clinical, intellectual and behavioural characteristics of $f r a(X)$ positive females.

Clinical evaluation revealed in all seven, one or more symptoms and stigmata which have previously been reported as characteristic findings in fra $(X)$ males. As in the fra(X) prepubertal males the most striking observation was the overgrowth syndrome, closely resembling the findings in cerebral gigantism (Sotos syndrome) and starting from the prenatal period on. In three girls all growth parameters were above the $97 \mathrm{th}$ percentile for age at the time of examination and true macrocephaly was present in five girls. It is thus evident that, as in male patients, a fragile $X$ screening should be performed in all retarded girls with a growth pattern suggestive of the clinical diagnosis of Sotos syndrome (Beemer et al. 1986). A long face was seen in five girls and in the two others the face was round and full. Epileptic attacks, which are also a frequent finding in fra( $X)$ boys (Fryns 1984), were observed in one girl.

Up to now, the data reported in the literature on the phenotype in fra $(X)$ carriers has been relatively scanty and conclusions have not been unequivocal. As far as we know, no reports have studied the phenotypic features in prepubertal fra $(X)$ positive girls. Subtle physical stigmata were discovered in female carriers by Hagerman \& Smith (1983). In a study of 144 adult obligate heterozygotes we found clinically recognisable stigmata, i.e. long face, large forehead, relative macrocrania and large ears in $28 \%$ of them (Fryns 1986). These findings were recently confirmed in a large Australian survey (Loesch \& Hay 1988).

The $\mathrm{fra}(X)$ expression in the $7 \mathrm{fra}(X)$ girls in the present study varied between 2 and $30 \%$ and no correlation was seen between the percentage of $\mathrm{fra}(X)$ positive cells and intelligence or phenotype. Large surveys on the fra(X) findings in adult female obligate carriers came to the conclusion that a positive fra $(X)$ screening is found in only $50 \%$ of the patients (Fryns 1986, Sherman et al. 1985). Wolff et al. (1988) reported a positive fra $(X)$ screening in only $30 \%$ of the obligate female fra $(X)$ carriers and they explained this lower percentage of positive screening by the higher age of their study group. In addition to age, the intellectual level of female carriers was found to be correlated with $\mathrm{fra}(X)$ expression by Chudley et al. (1983). These authors found a negative correlation between intelligence and the expression of the $\mathrm{fra}(\mathrm{X})$ in female carriers.

IQ measurement on the Terman and Wechsler scales of the $7 \mathrm{fra}(\mathrm{X})$ positive girls in the present study revealed a widespread variation of $1 \mathrm{QQ}$, between 50 and $\mathbb{1 3 5}$ (mean $I Q=91.7$ ). One girl was moderately mentally retarded, two were borderline retarded and two had low normal intelligence. Previous studies of obligate female $\mathrm{fra}(\mathrm{X})$ carriers have shown that $30 \%$ or more of the female heterozygotes are cognitively impaired, ranging from mild learning disorders to moderate mental retardation (Turner et al. 1980, Fryns 1986, Sherman et al. 1983 , Chudley et al. 1983). Wolff et al. (1988) reported that more than $50 \%$ of their female 
subjects were either retarded or learning disabled.

After analysis of the subtest scores, the results of the present study did not indicate any consistent profile of strengths or weaknesses in this group nor a pattern of verbal versus performance discrepancies. This was confirmed by the study of Wolff et al. (1988). They did not find any significant difference but their results revealed that heterozygotes, in comparison with a control group, performed more poorly on language function, short-term memory and arithmetic. On the other hand, other investigators (Ushida et al. 1983, Madison et al. 1986, Veenema et al. 1987) have reported important verbal-performance discrepancies on the Wechsler Intelligence test, i.e. non-retarded fra(X) carriers in general showed greater proficiency on verbal than on performance measures. Hagerman \& Smith (1983), Kemper et al. (1986), Miezejski et al. (1986), Theobald et al. (1987) also described consistent scatter profiles with arithmetic, digit span and block design depressed relative to the mean measures.

A constant observation in the study of female fra $(X)$ carriers is the common behavioural features, and this was also a consistent finding in this study. Severe attentional problems were noted in all seven girls. Two of them even demonstrated the Attention Deficit Hyperkinetic Disorder (ADHD), a typical finding in $\mathrm{fra}(\mathrm{X})$ boys (Borghgraef et al. 1987). Five of the $7 \mathrm{fra}(X)$ girls were, in addition, extremely shy with social withdrawal and limited eye-contact. Anxiety and sudden, unexpected bursts of panic were seen in 4 of them. These observations are in complete agreement with the findings in previous studies. Hagerman \& Smith (1983) and Hagerman et al. (1986) described autistic features and other behavioural characteristics like shyness and difficulties in social contacts. Sobesky (1988) also reported on the psychological problems in mothers of fra $(X)$ children and noted disorganized thinking, anxiety, feelings of isolatic : and a damaged sense of self.

Study of the 7 fra $(X)$ positive girls reported here revealed an important variation in their cognitive profile, but disclosed two other almost constant features: an overgrowth syndrome present from birth on and common behavioural problems, i.e. severe attentional problems and extreme shyness and anxiety in some of them. These seem to be the most important clinical selection criteria for $\mathrm{fra}(\mathrm{X})$ screening in females in general, and, more specially, in prepubertal girls.

\section{References}

Beemer, F. A., H. Veenema \& J. M. De Poter (1986) Cerebral gigantism (Sotos syndrome) in two patients with fra $\mathrm{X}$ chromosomes. $A m . J$. Med Genet. 23, 221-226.

Borghgraef, M., J. P. Fryns, A. Dielkens, K. Pyck \& H. Van den Berghe (1987). Fragile $(X)$ syndrome: a study of the psychological profile in 23 prepubertal patients. Clin. Genet. 32, $179-186$.

Brøndum-Nielsen, K. (1983). Diagnosis of the fra $X$ syndrome: clinical findings in 27 males with the fragile site at Xq28. J. Ment. Defic. 27, $211-226$.

Chudley, A. E., J. Knoll, J. W. Gerrard, L. Shepel, E. McGahey \& J. Anderson (1983). Fragile ( $X$ ) $X$-linked mental retardation. I: Relationships between age and intelligence and the lrequency of expression of fragile Xq28. Am. $I$. Med Genet. 14, 699-712.

Fryns, J. P. (1984). The fragile $X$ syndrome. A study of 83 families. Clin. Gener. 26, 497-528. Fryns, J. P. (1986). The female and the fragile $X$. A study of 144 obligate lemale carriers. $A m * J$. Med Gener. 23, 157--169.

Fryns, J. P., A. Kleczkjowska, F Kubien \& H. Van den Berghe (1984). Cylogenetic rindings in moderate and severe mental retardation. A study of an institutionalized population of 1991 patients. Acta Paediar. Scand. Supplement 313.

Hagerman, $\mathbb{R}$. J., A. E. Chudley, J. H. Knoll, A. W. Jackson, M. Kemper \& R. Ahmad (1986). Autism in fra X Temales. Am. J. Med Genet. $23,375-380$. 
Hageman, R. J. \& A. C. M. Smith (1983). The heterozygous femalle. In The Fra $X$ Syndrome Diagnosis, Biochemistry and intervention. R. J. Hagerman \& P. M. McBogg (eds.) Dollon, Colo, Spectra Publishing Co. Ine., pp. 83-94. Jacobs, P. H. Mayer, J. Matsuna, F. Rhoads \& S. C. Le (1983). A cytogenetic situdy of a population of mentally retarded males with special reference to the marker $(X)$ syndrome. Hum. Genet. 63, 139148 .

Kemper, M. B., R. J. Hagerman, K. S. Ahmad \& R. Mariner (1986). Cognitive profiles and the spectrum of clinical manifestations in heterozygous fra(X) females. Am. I. Med Genet. 23, 139156 .

Loesch, D. Z. \& D. A. Hay (1988). Clinical fealures and reproductive patterns in fragile $X$ female heterozygotes. J. Med. Genet. 25 , $407-414$.

Madison, L. S., C. George \& I. B. Hoeschler (1986). Cognitive functioning in the fra $X$ syndrome: a study of intellectual, memory and communication skills. J. Ment. Defic. Res. 30, 129-148.

Mattei, J. F., M. G. Mattei, C. Aumeras, M. Auger \& F. Giraud (1981). X-linked mental retardation with the fra $X$ : a study of 15 families. Hum. Genet. 59, 281-289.

Miezejski, C. M. E. C. Jenkins, A. L. Holl, K. Wisniewski \& W. T. Brown (1986). A profile of cognitive deficit in females of fra $X$ families. Neuropsychologia 24, 405-409.

Opit 2 , I. M. \& G. R. Sutherland (1984). Conference report: international workshop on the fra $\mathrm{X}$ and $\mathrm{X}$-linked mental retardation. $A m . J$. Med Gender. 17, 5-94.

Sherman, S. L., P. A. Jacobs \& N. E. Morton (1985). Further segregation analysis of the fra $X$ syndrome with special reference to transmitling males. Hum. Genet. 69, 289-299.

Sherman, S. L., N. E. Morton, P. A. Jacobs \& O. Turne" (1983). The marker $X$ syndrome: a cylogenetic and genetic analysis. Amm. Hom. Genet, $48,21-37$.
Sobesky, W. E. (1988). Psychological problems fra $X$ females. The National Fra $X$ Foundato Newsletter, Demver, Colorado, 4, $1-2$.

Sutherland, G. R. (1979). Heritable fragile silt on human chromosomes: factors affecting pression in lymphocyte culture. Am. $J$. Mit Genet. 31, 125-135.

Terman, L. M. \& M. A. Merrill (1973). Stamford Bine Intelligence Scale. Mawtal for the Thin Revision Form. Chicago, The Riverside Pubi Co.

Theobald, T. M., D. A. Hay \& C. Judge (1987) Individual variation and specific cognituve deff cits in the fra X syndrome. Am. J. Med Gent $28,1-11$.

Turner, G., R. Brookwell, A. Daniel, M. Seliko vitz \& M. Zillibovitz (1980). Heterozygous a pression of $X$-linked mental retardation and? chromosome marker fra (X)q27. N. Engl. Med. 303, 662

Ushida, I. A., V. C. P. Freeman, H. Jamro, M. W Partingon \& H. C. Soltan (1983). Additione evidence for fra(X) activity in heterozygon carriers. An. J. Hun. Genet. 35, 861-867.

Veenema, H., T. Veenema \& J. P. M. Geraerdt (1987). The fra $X$ syndrome in a large family II. Psychological investigations. J. Med. Getw 24, 32-38.

Wechster, O. (1974). Manual for the Wechsler Jy telligence Scale for Children - Revised. Nen York, The Psychological Corporation.

Wolf, P. H., J. Gardner, I. Loppen, J. Paccia \& D. Meryesh (1988). Variable expression of thy fra $X$ syndrome in heterozygous females normal intelligence. Am. J. Med Genel. $213-225$.

Address:

J. P. Fryns

Centre for Human Gentetco

Herestrat 49

B-3000 Letwen

Belginm

p. 82. alinea 5: delete: above the 97th percentile

P. 82. Table 1. Patient 3, physical features: $P 27=P 75$

p. 84. alinea 28: above the 97 percentile $=$ above the 50 th percentile

p. 84. alinea 30 : five $=\operatorname{six}$ 


\section{CONCLUSION X-I_INKED MENTAL RETARDATION}

After the discovery of the fra $(X)$ syndrome, after 21 -trisomy the most frequent type of mental retardation in the male, several studies have attempted to define objective criteria and indications for fra $(X)$ screening in the mentally retarded (Hagerman \& Bogg, 1983; Turner et al., 1986; Bregman et al., 1987). In adult fra( $(X)$ positive males at least two thirds present the classical triad "moderate mental retardation- long face with large everted ears - large testes". In young fra $(X)$ boys; however, the key towards early diagnosis is mostly not their phenotypic abnormalities but their behavioural profile. Therefore, we were interested in a better delineation of the psychological profile in $f r a(X)$ boys and further analyzed their pattern of developmental and behavioural problems.

Summarizing the data on intellectual functioning of our fra $(X)$ boys (Borghgraef et al. 1987, Borghgraef et al. 1988), the majority (43\%) were found to be moderately mentally retarded, $31 \%$ had a mild mental retardation, $17 \%$ were severely mentally retarded and $7 \%$ were profoundly retarded. The mean IQ was 38.6 with spread between IQ 18 and 74 (Table 1). One of the most important observations was the negative correlation between level of intellectual functioning and age. These data were in strong agreement with literature data.

This decline in IQ was both inter- and intra-indlvidual. The prepubertal fra $(X)$ boys performed a lot better than the postpubertal group (Table 2). Furthermore, we collected longterm IQ data of fra $(X)$ boys and boys of the control group and compared these results. A strong negative correlation between age and intellectual level in most of the fra $(X)$ boys was demonstrated. This negative relationship was further confirmed in a multicenter study of $101 \mathrm{fra}(X)$ males (Fish et al., 1990).

Some decline in Intellectual performances are a general observation in a mentally retarded population but in the fra $(X)$ group it seems to be a lot more pronounced.

Most mildly mentally retarded $f r a(X)$ males dropped to the level of moderate mental retardation and $50 \%$ of the moderately mentally retarded fra $(\mathrm{X})$ boys became severely retarded. We have no arguments to explain this decline of IQ's by deterioration or loss of acquired skills. Different causal factors are probably involved, e.g. the severe behaviourall problems, and therefore further investigations are needed to find a plausible explanation. The pattern of cognitive abilities was analyzed by systematic standardized psychometric testing. The majority of the fra $(X)$ patients dild not show any significant differences between verbal and performance intelligence.

Subtest analysis showed no significant differences between subtests and no 
salient cognitive strengths or weaknesses could be ascertained in the fra $(X)$ group, in comparison with the control group (Curfs et al. 1989).

In the second part of the study of the psychological proflle of fra(X) boys we were interested in the most obvious behavioural features and problems encountered in fra $(X)$ boys l.e. hyperkinetic behaviour and autistic reactions. Hyperkinetic behaviour (or $A D H D$ ) was significantly more common in tra( $(X)$ boys compared with the findings and observations in fra $(X)$ negative males with socalled idiopathic mental retardation (Table 3). Poor attentlon and concentration, extreme hyperactivity, impulsivity and verbal unstructuredness were the most distinct symptoms. They were found to be age dependent and equally present in the different IQ groups. Especially in the youngest group of $f r a(X)$ males these characteristics were the most difficult problem for parents and teachers to cope with. Autistic features were found in $30 \%$ of the fra $(X)$ males (Table 4). The most obvious symptoms were fluttering and other stereotyples, sensory oversensitivity and distinct relational disturbances due to their soclal anxiety. These were most pronounced in the lowest functioning boys.

Finally, observations and psychometric testings were performed in fra(X) carriers and they revealed important variations in their cognitive development. Two constant features, very similar to those present in fra $(X)$ boys, were present in all these females: an overgrowth syndrome and distinct behavioural problems lie. severe attentional difficulties and extreme shyness due to social anxiety. Further studies are needed to confirm these preliminary findings as they are of great value in the early recognition of the syndrome in females, and allow proper educational help and genetic counseling.

The scientific knowledge on different aspects of the fra $(X)$ syndrome is steadily increasing. Up to now, little is known about the possibilities and effect of medical and educational treatment. At the present time the majority of fra $(X)$ boys is admitted In schools for the moderately mentally retarded. Teachers and educators, confronted with the dally care of these children, claim for more practical information on the possibilities and limitations of medical treatment and educational theraples, adapted to the proper needs of fra $(X)$ boys. Accurate information can only result from further research in this fascinating area. 


\section{References}

Borghgraef M., Fryns J.P., Dlelkens A., Pyck K. \& Van den Berghe H.

Fragile $X$ syndrome: a study of the psychological profile in 23

prepubertal patients. Clin. Genet. 32, 179-186, 1987.

Borghgraef M., Fryns J.P., Van den Bergh R., Pyck K. \& Van den Berghe H.

The postpubertal fra $(X)$ male: a study of the intelligence and the

psychological profile of $17 \mathrm{fra}(X)$ boys. In: Key Issues in Mental

Retardation Research. Proceedings of the Eighth Congress of the International Association for the Sclientific Study of Mental Deficiency (IASSMD), Dublin, Ireland, 21-25 August, 1988. W.I. Fraser Ed.

Routledge, London and New York, 1990.

Bregman J.D., Dykens E., Watson M., Ort S.I. \& Lecherman J.F. Fragile-X

syndrome: variability of phenotyplic expression. J. Am. Acad. Child

Adollesc. Psychiat. 26, 463-471, 1987.

Curfs L.M.G., Schreppers-Tijdink G., Wiegers A., Borghgraef M. \& Fryns J.P.

Intelligence and cognitive profile in the fra $(X)$ syndrome: a longitudinal

study in 18 fra $(X)$ boys. J Med. Genet. 26, 443-446, 1989.

Fisch G.S., Arinami T., Froster-Iskenius U., Fryns J.P., Curfs L.M.,

Borghgraef M., Howard-Peebles P.N., Schwarts C.E., SImensen R.J. \&

Shapiro $L . R$. The relationshlp between age and $I Q$ among fragile $X$

males: a multicenter study. A. J. Med. Genet. 38, 481-487, 1991.

Hagerman R.J. \& McBogg P.M. ed. The Fra X Syndrome. Dlagnosis,

Biochemistry and Intervention. Dillon, Spectra Publishing, 1983.

Turner G., Robinson H., Laing S., Purvis-Smith S. Preventive screening for the fra $X$ syndrome. New Engl. J. Med. 315, 607-609, 1986. 
Table 1. Proportional distribution of the fra(x) group in relation to the intell lectual level

\begin{tabular}{lccc}
\hline Mental retardation level & & Fra $(x)$ boys & Mean IQ \\
\hline mild & $n$ & $x^{2}$ & 62 \\
moderate & 12 & 31 & 43.5 \\
severe & 18 & 45 & 30 \\
profound & 7 & 17 & $<19$ \\
Total & 3 & 7 & 38.6 \\
\hline
\end{tabular}

Table 2. Proportional distribution of both age groups of $f r a(x)$ boys in relation to their intellectual level

\begin{tabular}{|c|c|c|c|c|c|c|}
\hline \multirow{2}{*}{$\begin{array}{l}\text { Level of mental } \\
\text { retardation }\end{array}$} & \multicolumn{3}{|c|}{$\begin{array}{l}\operatorname{Fra}(X) \text { boys } \\
(2 y-12 y)\end{array}$} & \multicolumn{3}{|c|}{$\begin{array}{l}\text { Fra }(x) \text { boys } \\
(15 y-23 y)\end{array}$} \\
\hline & $n$ & $\pi$ & mean IQ & $n$ & 7 & mean IQ \\
\hline $\begin{array}{l}\text { Myld } \\
\text { Moderate } \\
\text { Severe } \\
\text { Profound }\end{array}$ & $\begin{array}{r}11 \\
12 \\
0 \\
0\end{array}$ & $\begin{array}{r}48 \\
52 \\
0 \\
0\end{array}$ & $\begin{array}{l}61.5 \\
44\end{array}$ & $\begin{array}{l}2 \\
5 \\
7 \\
3\end{array}$ & $\begin{array}{l}12 \\
29 \\
41 \\
18\end{array}$ & $\begin{array}{l}63 \\
43.5 \\
30 \\
<19\end{array}$ \\
\hline Total & 23 & & 51 & 17 & & 34.4 \\
\hline
\end{tabular}


Table 3. Distribution of the Attention Defictt Disorder in both groups of patients, in relation to the intellectual level

\begin{tabular}{|c|c|c|c|c|}
\hline \multirow[t]{2}{*}{$\begin{array}{l}\text { Mental retardation } \\
\text { level }\end{array}$} & \multicolumn{2}{|c|}{$\begin{array}{c}\text { Fra }(x) \text { boys } \\
\text { with } A D H D\end{array}$} & \multicolumn{2}{|c|}{$\begin{array}{c}\text { Controll group } \\
\text { with ADHD }\end{array}$} \\
\hline & $n$ & $\pi$ & $n$ & 7 \\
\hline $\begin{array}{l}\text { Mild } \\
\text { Moderate } \\
\text { Severe } \\
\text { Profound }\end{array}$ & $\begin{array}{l}8 / 12 \\
8 / 18 \\
3 / 7 \\
2 / 3\end{array}$ & $\begin{array}{l}66 \\
44 \\
42 \\
66\end{array}$ & $\begin{array}{l}2 / 10 \\
4 / 13 \\
2 / 15 \\
0 / 0\end{array}$ & $\begin{array}{l}20 \\
30 \\
33 \\
-\end{array}$ \\
\hline Total & 21 & 52 & 8 & 27 \\
\hline
\end{tabular}

$p=0.019$

Table 4. Distribution of autistic behaviour in both groups of patients, in relation to the intel lectual level

\begin{tabular}{|c|c|c|c|c|}
\hline \multirow[t]{2}{*}{$\begin{array}{l}\text { Mental retardation } \\
\text { level }\end{array}$} & \multicolumn{2}{|c|}{$\begin{array}{l}\text { Fra }(x) \text { boys with } \\
\text { autistic behaviour }\end{array}$} & \multicolumn{2}{|c|}{$\begin{array}{l}\text { Control group with } \\
\text { autistic behaviour }\end{array}$} \\
\hline & & $\pi$ & $n$ & 7 \\
\hline $\begin{array}{l}\text { Mild } \\
\text { Moderate } \\
\text { Sever } \\
\text { Profound }\end{array}$ & $\begin{array}{l}2 / 12 \\
7 / 18 \\
3 / 7 \\
1 / 3\end{array}$ & $\begin{array}{l}17 \\
38 \\
42 \\
33\end{array}$ & $\begin{array}{l}0 / 10 \\
1 / 13 \\
0 / 6 \\
0 / 0\end{array}$ & $\begin{array}{l}0 \\
7 \\
0 \\
-\end{array}$ \\
\hline Total & 13 & 32 & 1 & 3 \\
\hline
\end{tabular}

$p=0.019$ 
PART II. OTHER CHROMOSOMAL SYNDROMES 



\section{A. SEX CHROMOSOMAL SYNDROMES}

\section{INTRODUCTION}

In contrast to autosomal abnormalities which result in a socalled MCA/MR (multiple congenital anomaly/mental retardation) syndrome, sex chromosome anomalies have a major effect on sexual development but, in the majority of them, much less on somatic and intellectual functioning. They occur in 1/400 male and 1/650 female livebirths. In most of the patients numerical aberrations of one or both sex-chromosomes are present, but, in the absence of important clinical symptoms, diagnosis at birth or at early age is rare. Up to now, detailed data on the physical and intellectual development of the more frequent sex-chromosome anomalies have been reported in the literature e.g. Turner syndrome (with a varlety of karyotypic changes: $45, X ; 45, X / 46, X X$ or other anomalies including structural aberration of the second $X$-chromosome), Klinefelter syndrome $(47, X X Y)$ and the $47, X Y Y$ syndrome.

Up to now, only a few studies are avallable on the intellectual development and psychological characteristics of children with rare sex chromosomal abnormalities. We had the opportunity to examine a group of young children with $X$ - and $Y$-chromosome polysomies, diagnosed at the Center for Human Genetics of the University of Leuven. In the following study we report on follow-up data of clinical observation, registration and psychometric evaluation of 8 young males with $49, X X X X X Y$ syndrome, 4 males with the $48, X X Y Y$ syndrome and 3 girls with $48, X X X X$ syndrome, and give special attention to the influence of each aberration on the patient's physical and psychologicall development. 
2. THE 49,XXXXY SYNDROME

2a. The 49,XXXXY syndrome. Clinical and psycholeglcal follow-up data 


\title{
The 49,XXXXY syndrome. Clinical and psychological follow-up data
}

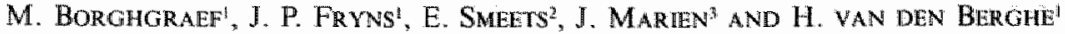 \\ Centre for Human Genetics, Department of Human Biology, Belgium, 2Paediatrician, Neerpelt, \\ Belgium, and Paediatrician, Lier, Belgium
}

\begin{abstract}
In this report we give a detailed description of the elinical and psychological follow-up data of three young $49, \times \times X X Y$ males, paying special attention to changes in intellectual performance and behaviour at different ages.
\end{abstract}

Received 16 Nowember 1987, accepted for publication 17 January 1988

Key words: mental retardation; poly-X-syndromes; sex-chromosomes; X-chromosome.

Since its first description by Fraccaro et al. (1960), the clinical features of the $49, \mathrm{XXXXY}$ syndrome have been well delineated by different authors (for review, see de Grouchy \& Turleau 1982), mostly in adult patients.

Up to now, however, few data have been available on the psychological and physical development of young males with this type of sex chromosome aberration.

\section{Report of Patients}

\section{Patient I}

J.Y. was the first child of healthy, unrelated parents. At his birth the father was 26 years and the mother 23 years old. From the beginning of the third trimester of this pregnancy intrauterine growth retardation was noted. Delivery was at the expected term. Birthweight was $2130 \mathrm{~g}$, length $48.5 \mathrm{~cm}$ and head circumference $31.3 \mathrm{~cm}$. In the neonatal perjod feeding problems occurred, and because of prolonged jaundice the boy remained in the neonatal care unit for 6 weeks.

In the presence of marked hypogonadism with a small, dorsally curved penis and hypoplastic scrotum, and hypertonia of the lower extremities, a chromosomal examination was performed. In all 50 cells of a lymphocyte culture, a $49, \mathrm{XXXXY}$ karyotype was found.

The postnatal growth curve (see Fig. 1) shows catchup growth after the age of 1 year. At the age of 6 years, herght was 120 $\mathrm{cm}$ (90th percentile), weight $19 \mathrm{~kg}$ (25th percentille) and head circumference $53 \mathrm{~cm}(90 \mathrm{th}$ percentile). In addition to the small external genitalia, craniofacial dysmorphism was evident (Fig. 2), with a broad nasal bridge and bilateral epicanthus. Except for a radioulnar synostosis of the left elbow and pedes plani, no other congenital anomalies were present.

Psychological findings. Psychomotor development was retarded from the beginning (sitting 8 months; walking 20 months; first words 30 months). At the age of 3.5 years, the boy was integrated with success in a normal infant school, and from the age of 6 years he started a special educational pro- 
gram. Psychological testing was performed at the age of 7 years. IQ was 50 with a mean developmental age of 4 years (WPPSI scale). A second evaluation at the age of 8 years revealed similar results (IQ 53 ; verbal IQ 47; performance IQ 59). Verbal intelligence was lower than performance skills. He performed best with puzzles and assortment tasks. Fine motor skills were poor. Speech defects with bad articulation were evident; there was good comprehension but poor expression. The boy also showed periods of
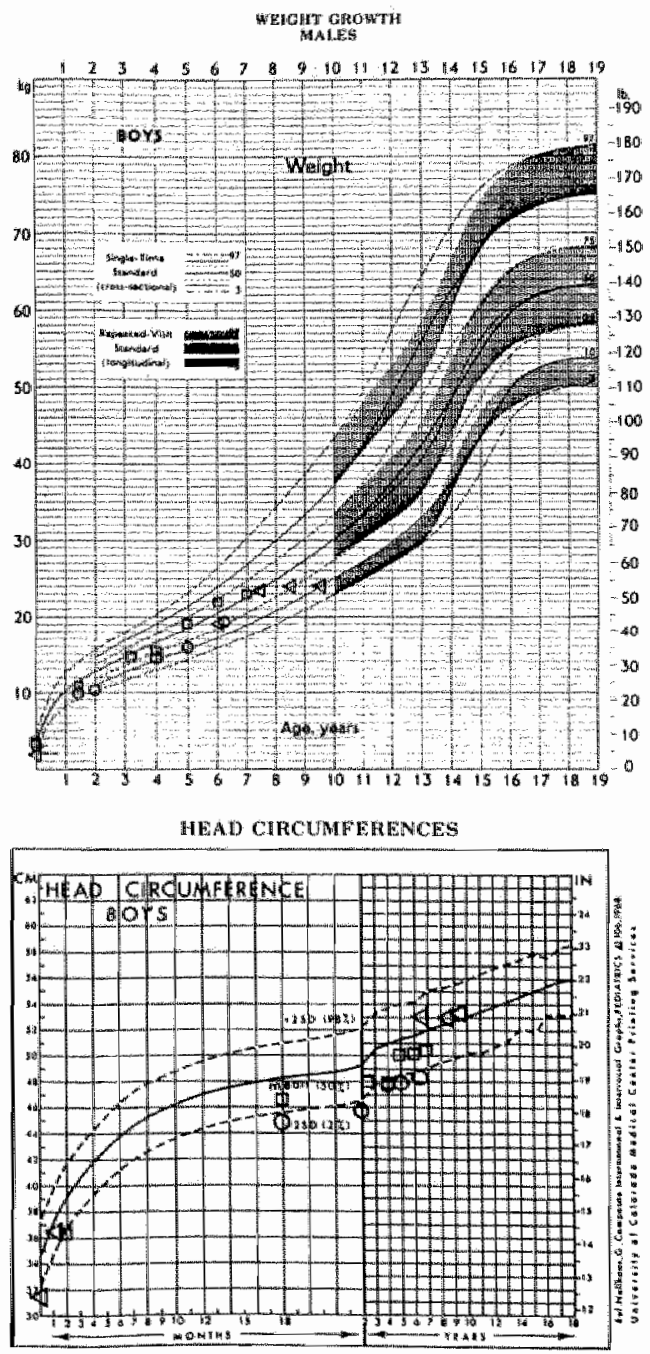

stereotyped language and his behaviour was shy and timid with periods of hyperkineticism, marked deficits in concentration and task motivation, and a low level of frustration tolerance.

\section{Patient 2}

V.D. was the second child of healthy, unrelated parents. At the boy's birth the father was 30 years and the mother 26 years old. Pregnancy and term delivery were normal.

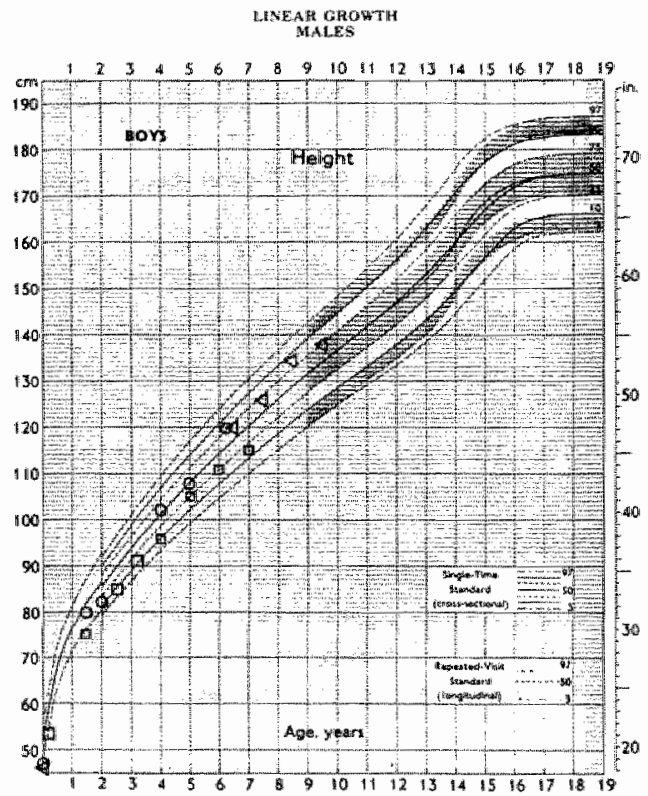

Fig. 1. The growth pattern (height, weight and head circumference) of the three $49, \times X X X Y$ males. $\triangle=\mathrm{Pa}$ tient 1. $\square=$ Pattent 2. $a=$ Patient 3. 
Birthweight was $2850 \mathrm{~g}$. No major problems occurred in the neonatal period. At the age of 6 weeks a chromosomal analysis was performed because of the presence of striking hypogenitalism (small penis, hypoplastic scrotum and small inguinal testes) associated with dysmorphic stigmata: caput quadratum, flat face with upturned nose, short neck, small thorax with widely spaced hypoplastic nipples and clinodactyly of the 5th fingers. Cytogenetic investigation of 30 cells of a lymphocyte culture showed a $49, \mathrm{XXXXY}$ karyotype in all cells (Gbanding).

The postnatal growth curve is illustrated in Fig. 1, and Fig. 3 shows the facial appearance at the age of 6 years. No internal malformations, nor radioulnar synostoses, are evident at the present age of 7.5 years.

Psychological findings. A delay in psychomotor development was noted from the be-

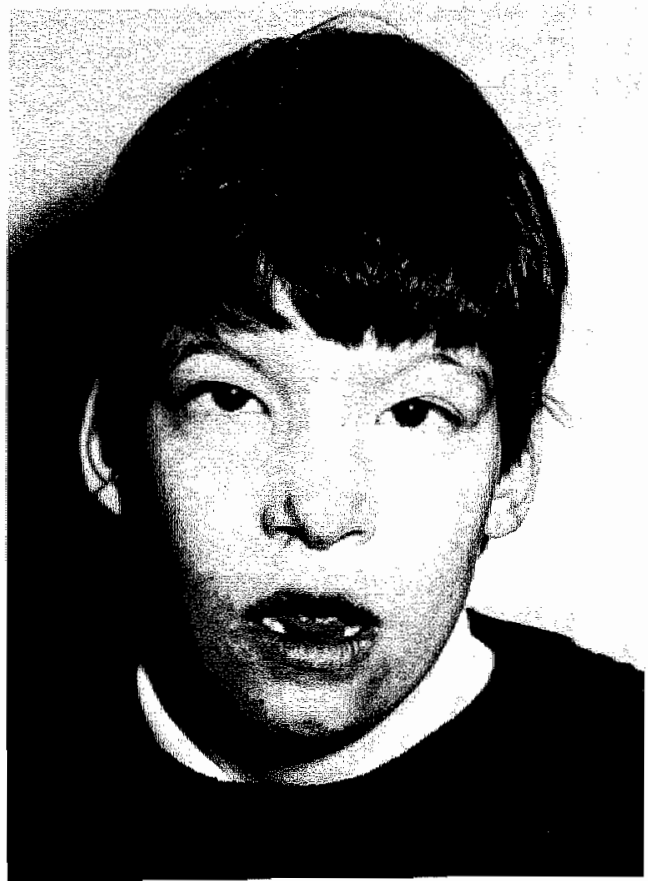

ginning (sitting at 8 months; walking at 20 months; and first words at 30 months). At the age of 3.5 years he was integrated in a normal infant school and at the age of 6 years he started in a special school. At the age of 5 years 3 months and at 6 years and 7.5 years, psychological evaluation was performed (WPSSI scalle) with the following results: 5 years 3 months: performance IQ 76 ; 6 years: total IQ 67 (verbal IQ 67 ; performance IQ 70); 7.5 years: total IQ 72 (verbal IQ 72; performance IQ 72).

Evaluation of cognitive function revealed the best results in performance tasks, with good performance in puzzles and block design. Speech started at the age of 3 years. The boy was difficult to understand and he spoke indistinctly. He had articulation defects and was very timid. His behaviour was shy, calm and quiet, with satisfactory self-assertiveness, adequate social integration and good task motivation. How-

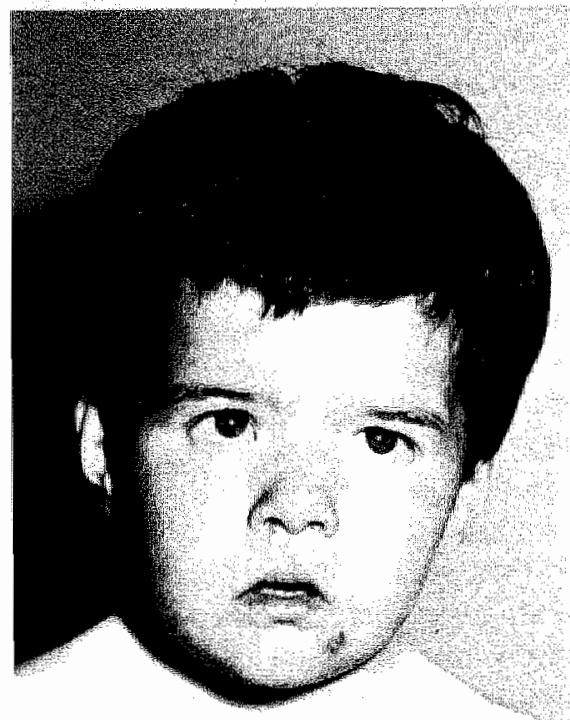

Fig. 2 and 3. The typical craniofacial appearance of Patient 1 (age 6 yearsil and Patient 2 (age 4 years) 
ever, he was wilful and showed a low frustration tolerance.

\section{Patient 3}

T.C., was the first child of healthy, unrelated parents. At the boy's birth the father was 26 years and the mother 24 years old. Pregnancy and term delivery were normal. Birthweight was $2270 \mathrm{~g}$, and length $47 \mathrm{~cm}$. Immediately after birth a chromosomal analysis was performed because of the association of hypotonia, hypogenitalism with small testes and hypoplastic scrotum, and brachycephaly with flat face, slight mongoloid position of the eyes and small upturned nose. Chromosomal analysis on a peripheral lymphocyte culture showed a $49, \mathrm{XXXXY}$ karyotype in all 35 examined cells. No other major physical problems were noted during the next months and years, and except for a bilateral radioulnar synostosis no other major internal anomalies were noted. The postnatal growth curve is illustrated in Fig. 1.

Psychological data. The early psychomotor development was delayed from the beginning (sitting at the age of 10 months; walking at 24 months and first words at 30 months). A first evaluation at the age of 2.5 years showed a global developmental level of 2 years. The developmental profile was harmonious except for poor language. At the age of 3 years he was integrated in a normal infant school. A follow-up evaluation at the age of 6 years on the WIPSSI scale revealed a total IQ of 72 (verbal IQ 70, performance IQ 78). Cognition: Performance tasks were well performed with best results in puzzles and assortment tasks. Performance in memory and language, however, was poor. The boy had good fine motor skills but gross motor movements were slow and clumsy. Language: The boy spoke in 2-3-word sentences. He had bad articulation and spoke indistinctly. Under- standing of verbal orders was satisfactory, but, as he was very timid, he did not answer questions. Behaviour: T.C. was shy, reserwed and quiet. He was wilful and reacted anxiously to new situations and unknown persons. He did not demand extra attention and was not eager to be cuddled.

\section{Discussion}

Over the past years more than 100 cases of $49, X X X X Y$ syndrome have been reported in the literature, including various types of mosaicism (Zaleski et al. 1966, Kardon et al. 1971, Terheggen et al. 1973, Karsh et al. 1975, Kaluzewski et al. 1977). The spectrum of clinical findings in this $\mathrm{X}$ polysomy syndrome has been delineated mostly in adult patients. In a review paper on the physical characteristics, Zaleski (1966) concluded that the $49, X X X X Y$ syndrome may not be considered as a variant of Klinefelter syndrome: $49, \mathrm{XXXXY}$ males present distinctive phenotypic features with a characteristic facial appearance somewhat suggestive of Down syndrome, marked hypogonadism, clinodactyly of the 5th finger and additional skeletal anomalies. Tumba (1972) found microcephaly to be present in a significant number of patients and, moreover, he reported general hypotrophy and stunted growth as an important general reature. Schmidt et al. (1978) concluded that osseous involvement may be variable from patient to patient but that epiphyseal dysplasia was a constant finding in all patients.

The three young $49, \mathrm{XXXXY}$ males reported here presented from birth with a characteristic facial appearance with quadrangular head shape, flat face with upturned nose, broad nasal bridge and bilateral epicanthus, short neck, marked hypogenitalism and small thorax with widely spaced hypoplastic nipples. Radioulnar synostosis was present in two of the three boys. There 
was, however, no postnatal decline of growth and physical development. On the contrary, two of the three males were small for dates $(2130 \mathrm{~g}$ and $2170 \mathrm{~g}$ at the expected terms) and presented a progressive and significant catchup of growth being at Percentiles 50 and 75 for height, respectively, after the age of 4 years. True microcephaly was only present in one of the three boys $(\mathrm{Pa}$ thent 3), and in none of them were additional internal malformations or other life-threatening anomalies noted.

Up to now, few data have been available on the intelligence, the cognitive profile and the psychological and behavioural profile of $49, \times X X X Y$ patients. We have tried to collect precise information on these parameters by regular observations and evaluations of our three young patients from birth on.

Literature data (Zaleski 1966, Moor 1967, Tumba 1972, Fjord Christensen \& Therkelsen 1970, Shapiro et al. 1971) indicate a widespread variation of intellectual performance in the $49, \times X X X Y$ syndrome (IQ between 20 and 70) with a mean IQ of 35. The majority of adult patients appeared to be moderately to severely retarded. The present three young 49, XXXXY males have at their present ages $(8,7.5$ and 6 years. respectively) a relatively higher $I Q$ with a mean of $65(53,70$ and 72 , respectively). Shapiro et al. (1970) noted a decline in intellectual development with age in one 49. XXXXY boy. According to these authors, this boy did not present signs of mental retardation at the age of 15 months but showed a deceleration at a later age. The same phenomenon of mental deceleration was noted by Schmidt et al. (1978) in another $49, \mathrm{XXXXY}$ male. We observed a similar decline in intellectual function in the third patient. At the age of 2.5 years he performed almost adequately for age except for expressive language. Now, at the age of 7.5 years, he attends a special school and evaluation on the WPSSI scale at age 6 revealed a total IQ of 70 .

Subtest analysis of the results of intellectual testing in the present three boys revealed a much better performance on non-verbal tasks, especially puzzles and assortment tasks, but poor memory and fine motor skills. All three presented a general severe retardation in language development and poor speech fluency. Morić-Petrović et al. (1973) reported similar observations, i.e. general developmental retardation with disproportion between verbal ability and understanding. Moor et al. (1967) also noted better reasoning than language performance.

We were most impressed by the similarity in character and behaviour of our three $49, \times X X X Y$ patients and found them to be extremely timid and shy. They avoided eye contact by hiding their faces, dared not speak and felt very insecure. In general, there was good social integration but no initiative for social interaction. Frustration tolerance was low in the three males and they reacted very strongly to minor changes. Details of behaviour in the $49, \times X X X Y$ syndrome were only mentioned by Zalesky et al. (1966): their 49, XXXXY patients manifested strong negative reactions after being exposed to any stressful situation.

Experience with the present three patients seems to indicate that the diagnosis of the $49, X X X X Y$ syndrome in the neonatal per. iod, together with appropriate information to the parents and psychosocial follow-ap of the children, is of utmost importance for adequate social and intellectual functioning of these males in later life.

\section{References}

de Grouchy, J. \& C. Turleau (1982). Atlas des Maladies Chromosomiques. Paris, Expansion Scientifique, p. 407

Fjord Christensen, M. \& A.J. Therkelsen (1970).

A case of the XXXXY chromosome anomaly 
with four maternal $X$ chromosomes and diabetic glucose tolerance. Acta Paediatr. Scand. 59, 706-710.

Fraccaro, M., K. Kaijser \& G. J. Lindsten (1960). A child with 49 chromosomes. Lancet ii, 899-902.

Kaluzewski, B., D. Podkwl, 1. Zabrowska, T. Moruzgialla \& L. Jakubowski (1977). The $48, \times \times \times \times / 49, \times \times \times X$ i (Yq) mosaicism in a 3year-old boy from a twin pregnancy. Hum. Gener. 37, 355-359.

Kardon, N. B., N. G. Beratis, L. Y. F. Hsu, R. F. Moloshok \& K. Hirschhorn (1971). 47XXY/ $48 \times X \times Y / 49 \times \times X X Y$ mosaicism in a 4 -yearold child. Am. J. Dis. Child 122, 160-162.

Karsh, R. B., R. F. Knapp, J. J. Nora, R. P. Wolfe \& A. Robinson (1975). Congenital heart disease in 49,XXXXY syndrome. Pediatrics $\mathbf{5 6}$, $462-464$.

Moor, L. (1967). Niveau intellectuel et polygonosomie: confrontation du caryotype et du niveau mental de 374 malades dont le caryotype comporte un exces de chromosomes X ou Y. Rev. Neuropsych. infant. 15, 325-348.

Morić-Petrović, S., Z. Laca, S. Marković \& V. Marković (1973). 48,XXXXY karyotype in a mentally retarded boy. J. Ment Defic. Res. 17, 73-80.

Schmidt, R., M. Pajewski \& M. Rosenblatı
(1978). Epiphysial dysplasia: a constant finding in the XXXXY syndrome. $J$. Med. Genet. 15 , 282-287.

Shapiro, L. R., C. B. Brill, L. Y. Hsu, M. E: Calvin \& K. Hirschhorn (1971). Deceleration of intellectual development in a XXXXY child. Am. J. Dis. Child. 122, 163-164.

Terheggen, H. G., R. A. Pfeiffer, H. Haug, M. J. Hertl. A. Diggins \& W. Schünke (1973). The XXXXY syndrome. Z. Kinderheilk. 115, 209-232.

Tumba, A. (1972). Le phénotype XXXXY étude analytique et synthétique à propos de 3 cas personnels et de 67 autres cas de la littérature. J. Génét. Hum. 20, 9-48.

Zaleski, W. A., C. Stuart Houston, J. Pozsonyl \& K. L. Ying (1966). The XXXXY chromosome anomaly: report of three new cases and review of 30 cases from the literature. Can. Med. As* soc. J. 94, 1143-1154.

\section{Address:}

Dr J. P. Fryns

Centre for Human Generics

Department of Human Biology

U.Z. Gasthuisberg

Herestraat 49

B-3000 Leuven

Belgium 
2b. The 49,XXXXY syndrome. Clinical and psychological findings in five patients 
$\therefore$ 


\title{
The 49,XXXXY syndrome: clinical and psychological findings in five patients
}

\author{
L. M. G. CURFS, G. SCHREPPERS-TIJDINK,' A. WIEGERS, \\ M. BORGHGRAEF ${ }^{2}$ AND J. P. FRYNS ${ }^{2}$ \\ ${ }^{\prime}$ Obserwation Centre de Hondsberg, Oisterwijk, The Netherlands, and ${ }^{2}$ Center for Human \\ Genetics, University of Lewven, Belgium
}

\begin{abstract}
In this study dinical and psychological findings are presented in five $49, \mathrm{XXXXY}$ patients. Their degree of mental recardardorn varied greatly, i.e. from moderately to profoundly retarded. A decline in intelligence performance with age was observed in one boy. Language development was severely retarded with a renarkable discrepancy between language expression and comprehension. Emocional disturbances with low frustration level, timidity and shyness were noted in all hive and their level of adlaptive functioning was much higher than the cognive level.
\end{abstract}

\section{INTRODUCTION}

Up to now, only a few specific studies are available on the psychological characteristics of 49, XXXXY patients (Borghgraef et al., 1988; Shapiro et al., 1971; Sheridan \& Radlinski, 1988). More data have been reported on the clinical findings since the first description of this X-chromosome polysomy syndrome by Fraccaro et al. (1960) (see for review Zaleski et al., 1966; Tumba, 1972). From birth on, $49, \mathrm{XXXXY}$ males present distinctive phenotypic features combining characteristic craniofacial abnormalities with skeletal deformities and microgenitalism. Microbrachycephaly with mongoloid position of the eyes, epicanthus and short neck are also evident later in life and give the impression of a mongoloid appearance.

\section{MATERIAL AND METHODS}

In this study, clinical and psychological findings are presented on five Dutch $49, \times X X X Y$ patients, now $13,13,22,28$ and 42 years old, respectively. The authors were able to follow these patients for several years and to collect data on their early development. Four of the patients are institutionalized and one stays in a day-care centre.

\section{CLINICAL DATA}

The most important clinical findings are summarized in Table I (see also Fig. 1) and they are compared with the findings in previously reported patients (see Levy et al, 1978).

Correspondence: F. P. Fryns, Center for Human Genetics, UZ Crasthuisberg, Herestrac 49, B-3000 Lewwen, Belgium. 
108 L. M. G. Curfs et al.

Table 1 Clinical data of the five parients

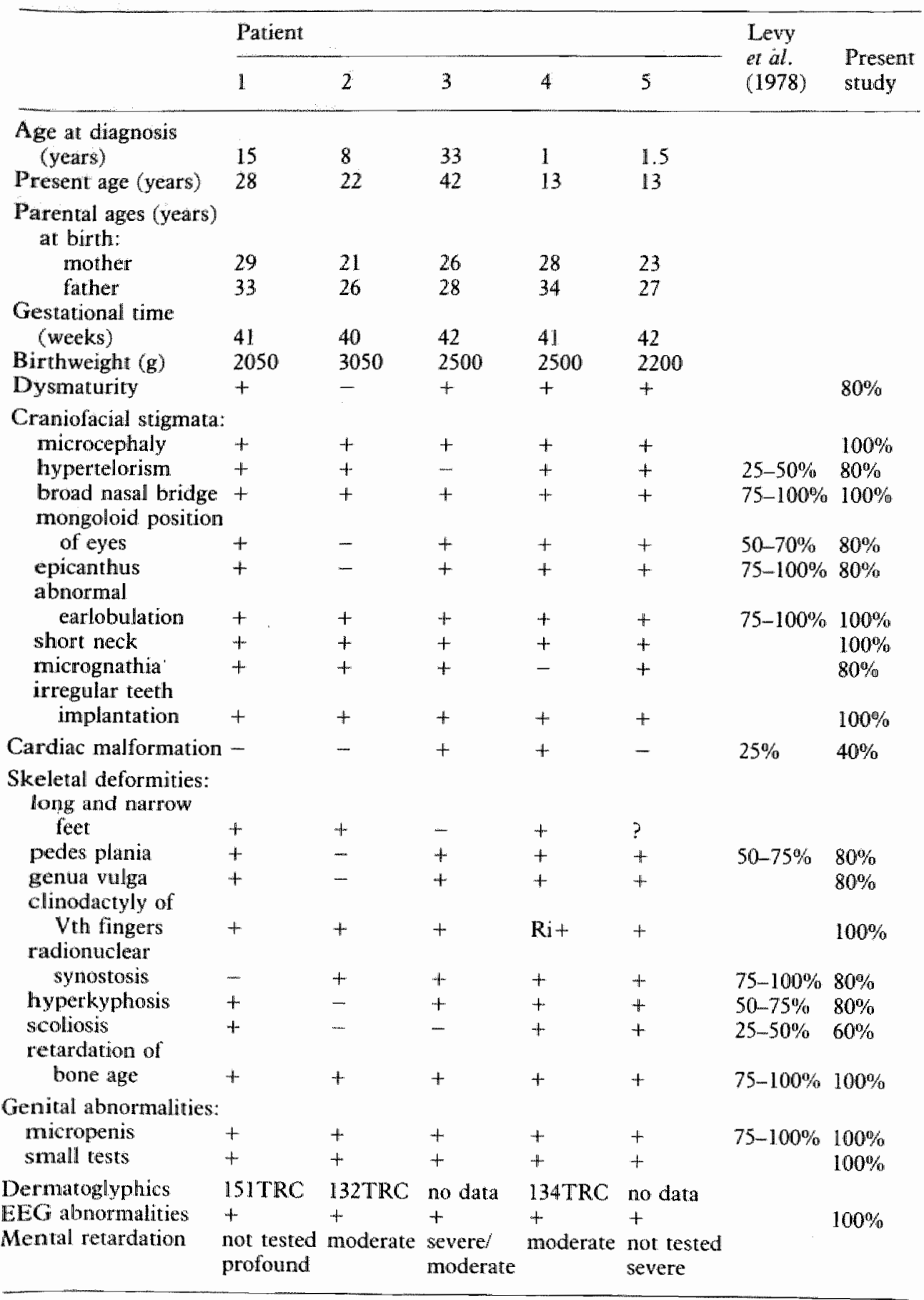




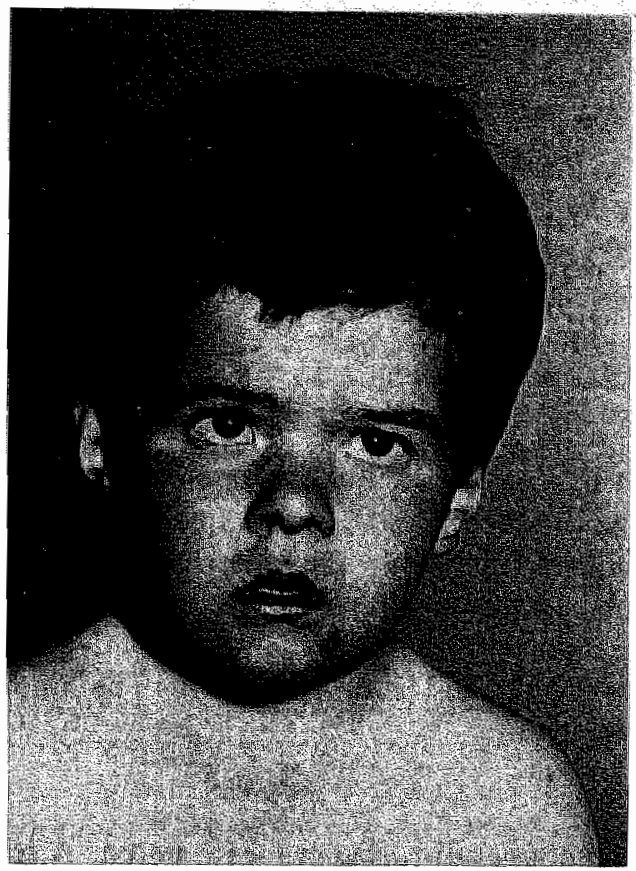

Fig. 1 The typical craniofacial appearance at the age of 4 years.

\section{PSYCHOLOGICAL DATA}

\section{Intelligence}

All the adult patients were mentally retarded. One of these patients was profoundly, one severely and one moderately mentally retarded. The two younger patients were both severely mentally retarded (the data are presented in Table 1). For one patient (patient 2: 22 years old), there was an indication of a decline in intellectual performance with age. Between the ages of 8 and 11 years, his intelligence level changed from mildly to moderately retarded.

\section{Motor development}

Psychomotor development was retarded from the beginning in all five patients. Gross motor control involving large areas of the body (sitting, standing and walking) was retarded (see Table 2).

Looking at these more complex and integrating motor acts, such as sitting and running, integrative problems can be seen and the patients give the impression of clumsiness.

\section{Language development}

With the exception of one patient (patient 4: 13 years old), language development was 
110 L.M.G. Curfs et al.

Table 2 Motor milestones (in years/months) in four of the five patients

\begin{tabular}{|c|c|c|c|c|}
\hline & \multicolumn{4}{|c|}{ Patient } \\
\hline & 1 & 2 & 3 & 5 \\
\hline Sitting & 2.0 & 0.9 & $?$ & 1.9 \\
\hline Standing & 2.6 & 0.10 & 1.6 & 2.6 \\
\hline Walking & 4.6 & 2.6 & 2.0 & 4.0 \\
\hline
\end{tabular}

severely retarded. All five patients showed serious articulation defects. Two of the patients are only able to produce sounds. One patient uses short incomplete sentences and demonstrates echolalic behaviour. The other patient uses more wordsentences. For one of the patients, language expression was not restricted, but perseverations and associations were noticed. All the patients showed a remarkable discrepancy between language expression and comprehension. The understanding of spoken language is better developed.

Behavioural profile

For all five patients, emotional disturbances were noted. A remarkable finding was the low frustration level and the strong reaction to minor changes (temper outbursts). Tracing the development of adaptive behaviour all five patients present moderately retarded adaptive functioning. This means that, for the majority, the level of adaptive functioning is somewhat higher than their cognitive level.

\section{DISCUSSION}

The five $49, \mathrm{XXXXY}$ males of the present study, aged between 13 and 42 years old, presented all the clinical characteristics of this chromosomal anomaly syndrome, as summarized in Table 1. Their degree of mental retardation varied greatly. One boy was moderately, three others were severely and one was profoundly mentally retarded. In one patient, there was an indication of a decline in intellectual performance with age: between the ages of 8 and 11 years, his intelligence level changed from mildly to moderately retarded. Literature data and the findings in this study indicate that the XXXXY syndrome is associated with moderate to severe mental retardation (Zaleski et al., 1966; Moor, 1967; Tumba, 1972; FjordChristensen \& Therkelsen, 1970; Shapiro et al., 1971). Younger patients seem to function at a somewhat higher intellectual level (Borghgraef et al., 1988; Zaleski et al., 1966). Up to now, only a few studies are available on intellectual performance with age (Shapiro et al., 1971; Sheridan \& Radlinski, 1988; Borghgraef et al., 1988). These studies as well as the findings in one of the present patients indicate a decline of intellectual performance during early childhood.

Delay in psychomotor development is a constant finding also reported in other studies (Zaleski et al., 1966; Shapiro et al., 1970; Fjord-Christensen \& Therkelsen, 
1970; Terheggen et al., 1973; Moric-Petrovic et al., 1973; Kushnick \& Colondrillo, 1975; Levy et al., 1978; Schmidt et al., 1978; Hari Singh \& Rajkowa, 1986; Sheridan \& Radlinski, 1988; Borghgraef et al, 1988).

Also in the present study, the five patients gave the impression of ciumsiness caused by integrative problems in their more complex motor acts like sitting and running.

All five patients presented severe retardation in language development with serious articulation defects and a remarkable discrepancy between language expression and comprehension.

Literature data indicate a severe retardation in language development and a poor fluency of speech. Poor expression in contrast to a better comprehension is also often reported (Zaleski et al., 1966; Moor, 1967; Shapiro et al., 1971; Moric-Petrovic et al., 1973; Kushnik \& Colondrillo, 1975; Schmidt et al., 1978; Levy et al., 1978; Sheridan \& Radlinski, 1988; Borghgraef et al., 1988).

Emotional disturbances with low frustration level and strong reactions to minor changes were a constant finding in all five patients, and were previously already noted in other patients by Zaleski et al. (1966) and Borghgraef $e t$ al. (1988).

Four of these patients, like those of Borghgraef et al. (1988), are also extremely timid and shy. Other behaviour problems were identified as inattentiveness and concentration difficulties, also mentioned by Sheridan \& Radlinski (1988), besides problems in social interaction. One of the present patients is pleasant and cheerful, a finding also reported by Moric-Petrovic et al. (1973), Hari Singh \& Rajkowa (1986) and Sheridan \& Radlinski (1988). In general, in literature limited information is available on social development of $49, \mathrm{XXXXY}$ patients.

In the present study, all patients presented moderately retarded adaptive functioning, i.e. the level of adaptive functioning is higher than the cognitive level. Only in a few studies adaptive behaviour of XXXXY patients is mentioned (Zaleski $a t$ al., 1966; Moric-Petrovic et al., 1973; Schmidt et al., 1978; Sheridan \& Radlinski, 1988). They also found a delay with respect to adaptive functioning of the patients.

Up to the present time, there is a great lack of precise studies on the psychological characteristics of XXXXY patients, especially of careful follow-up data. Gathering precise information on the cognitive and behavioural profile ar different ages is of an utmost importance. In the study on counselling needs for fra (X) families, Meryash \& Abuelo (1988) found that important issues for parents were availability of treatment and expectations for future functioning. It is likely that this finding applies to parents of $49, \mathrm{XXXXY}$ patients as well. Considering the severity of the syndrome, attention has to be given to the effects of early intervention and stimulation programmes. In this respect, it is also important to compare these patients with the XXXXY syndrome, who stay in situations or are less handicapped than patients cared for in the community or at home. Until now, no systematic studies on this topic are available.

\section{REFERENCES}

Borghgraef M., Frijns J.P., Smeets E., Marien J. \& Van den Berghe H. (1988) The 49

XXXXY syndrome. Clinical and psychological follow-up data. Clinical Genetics 33, 429-34.

Fiord-Christensen M. \& Therkelsen A.J. (1970) A case of the XXXXY chromosome anomaly 
with four maternal X chromosomes and diabetic glucose tolerance. Acta Paediatrica Scandinavica 59, 706-10.

Fraccaro M., Kaijser K. \& Lindsen J. (1960) A child with 49 chromosomes. Lancet ii, 899-902.

Hari Singh T. \& Rajkowa S. (1986) 49 XXXXY chromosome anomaly: an unusual variant of Klinefelter's syndrome. British Foumal of Psychiatry 148, 209-10.

Kushnick Th. \& Colondrillo $M$. (1975) 49 XXXXY patient with hemifacial microsomia. Clinical Genetics 7, 442-8.

Levy C.L., Sparkes Ch.L.R.S. \& Carlson H.E. (1978) Chromosome banding studies in two parients with XXXXY syndrome. Fournal of Medical Genetics 15, 301-16.

Meryash D.L. A Abuelo D. (1988) Counseling needs and attitudes toward prenatal diagnosis and abortion in fragile-X families. Clinical Genetics 33, 349-55.

Moor L. (1967) Niveau intellectuel et polygonosomie: confrontation du caryotype et du niveau mental de 374 mallades dont le caryorype comporte un excès de chromosomes X ou Y. Revue de Neuropsychiatrie Infantile 15, 325-48.

Moric-Petrovic S., Laca Z., Markovic S. \& Markovic V. (1973) 49 XXXXY karyotype in a mentally retarded boy. Fournal of Mental Deficiency Research 17, 73-80.

Schmidt R., Pajewski M. \& Rosenblatt M. (1978) Epiphysial dysplasia: a constant finding in the XXXXY syndrome. Foumal of Medical Genetics 15, 282-7.

Shapiro L.R., Hsu L.Y., Calvin M.E. \& Hirschhorn K. (1970) XXXXY boy: a 15-month-old child with normal intelligence development. American Journal of Diseases in Children 119, $79-81$.

Shapiro L.R., Brill C.B., Hsu L.Y., Calvin M.E. \& Hirschhorn K. (1971) Deceleration of intellectual development in a XXXXY child. American foumal of Diseases in Children 122, $163-4$.

Sheridan M.K. \& Radlinski S. (1988) Brief Report: a case study of an adolescent male with XXXXY Klinefelter's syndrome. Fournal of Autism and Developmental Disorders 18, 449-56.

Terheggen H.G., Pfeiffer R.A., Hang H., Hertl M., Diggins A. \& Schünke W. (1973). Das XXXXY-Syndrome. Bericht über 7 neue Fälle und Literatur-übersicht. Zeitschrift der Kinderhellkunde 115, 209-33.

Tumba A. (1972) Le phénotype XXXXY étude analytique et synthétique à propos de 3 cas personels et de 67 autres cas de la literrature. Foumal of Génétique Humaine 20, 9-48.

Zaleski W.A., Houston C.S., Pozsonyi J. \& Ying K.L. (1966) The XXXXY chromosome anomaly: report of three new cases and review of 30 cases from the literature. Canadian Medical Association Joumal 94, 1143-54.

Received 28 . March 1989; revised 10 July 1989

p. 109. Intelligence:

Paragraph should be as follows:

One of the adult patients was profoundly and two were moderatedly mentally retarded. Of the two younger patients one was moderately and the other severely
mentally retarded.

p. 110. alinea 3: echolalic behaviour is echolalia

Discussion: alinea 3: One boy was moderately, three others were severelly mentally retarded...

should be: Three were moderately, one was severely and one

profoundly mentally retarded 
3. THE 48,XXYY SYNDROME. FOLLOW-UP DATA ON CLINICAL CHARACTERISTICS AND PSYCHOLOGICAL FINDINGS IN 4 PATIENTS 
Genet. Couns., 1991, in press

\section{THE 48,XXYY SYNDROME. \\ Follow-up data on clinical characteristics and psychological findings in 4 patients.}

\section{BORGHGRAEF, J.P. FRYNS, H. VAN DEN BERGHE}

Centre for Human Genetics, U.Z. Gasthuisberg, Herestraat 49, B-3000 LEUVEN (Belgium).

\section{SUMMARY}

In this study we report the physical and psychological findings in 4 males with $48, X X Y Y$ syndrome. They were diagnosed at the ages of $4,6,18$ and 25 years respectively. The major indication for chromosomal analysis in these four slightly mentally retarded males was not their clinical appearance but the presence of behavioural problems with personality disturbances l.e. psychotic reactions, loss of structure, violent and impulsive reactions. These data are compared with previous findings in the literature.

Key-words : Sex-chromosomes - X chromosome polysomy - $Y$ chromosome polysomy - intelligence.

\section{Titre en trançais :}

Le syndrome $48, X X Y Y$. Sulvi du développement physique, intellectuel et psychologique chez 4 garçons.

Résumé : Dans cette étude nous rapportons les données physiques et psychologiques chez 4 garçons présentant le syndrome $48, X X Y Y$. Le diagnostic cytogénétique a été posé aux áges respectifs de $4,6,18$ et 25 ans. L'indication majeure pour l'examen chromosomique était chez tous les quatre les problèmes comportementaux avec réactions psychotiques, violentes et/ou impulsives. Ces données sont comparées aux données de la littérature.

Mots clés : chromosomes sexuels - polygonosomie $X$ - polygonosomie $Y$ intelligence. 


\section{INTRODUCTION}

Sex-chromosomal aberrations occur in two to seven per thousand livebirths [1] and include numerical and structural anomalies of the $X$ and $Y$ chromosomes.

The 48,XXYY syndrome was first described by Muldal and Ockey [2] and, since, some 60 other patients have been reported. XXYY boys seem to share physical features both with the $47, X X Y$ and with the $47, X Y Y$ syndrome [3].

In this paper we present clinical and psychological follow-up data on 4 males with this sex-chromosomal anomaly and discuss whether the syndrome is assoclated with typical clinical findings and distinct psychollogical characteristics.

\section{REPORT OF PATIENTS (see also Table 1)}

\section{Patient 1}

J.P. was the second child of healthy, unrelated parents. At his birth the father and the mother were 31 and 28 years old respectively. Birthweight was $2450 \mathrm{~g}$ and fength $49 \mathrm{~cm}$. Two days after birth generalized convulsions were noted and antiepileptic treatment was started up to the age of 2 years. Psychomotor delay was present from the beginning and at the age of 4 years he was sent to the Genetic Clinic for further diagnosis because of a progressive Increase of behavioural problems. Clinical examination revealed a boy in good general condition with hyperlaxity of all joints, truncular obesity contrasting with slender extremities and normal external genitalia. There was mild cranlofaclal dysmorphism with brachycephaly, maxillar hypoplasia and everted upper lip. Height was 112 $\mathrm{cm}(\mathrm{Pc} 97=110 \mathrm{~cm})$, weight $22 \mathrm{~kg}(\mathrm{Pc} 97=20.5 \mathrm{~kg})$ and head circumference $50.5 \mathrm{~cm}(\mathrm{Pc} 50=51 \mathrm{~cm})$. Chromosomal analysis was performed in two different peripheral blood lymphocyte cultures and showed a $48, X X Y$ karyotype in all 26 analysed cells.

IQ testing at that age revealed a Terman IQ of 71 . There was severe speech delay, poor memory and concentration difficulties. His performances and behaviour were quiet unstable. He demonstrated acting out and aberrant behaviour, alternated with periods of quiet, apathic reactions and limited eye contact. He asked to be cuddled and at the same time he may hurt you. This boy was rejecting rules and acted defiantly. He enjoyed hurting other children and making them angry. Observation at a Child Psychiatry Department indicated a personality disorder with total loss 
of structure and self-control, inducing violent and Impulstive reactions. $\mathrm{He}$ was admitted to a special school with further psychiatric guidance.

Patient 2 (Fig. 1).

V.K. was the second child of healthy unrelated parents of lower social class. At his birth the father was 32 years and the mother 27 years old. Birthweight was $2850 \mathrm{~g}$ and length $47 \mathrm{~cm}$. Psychomotor delay was seen only after the age of 3 years. At the age of 6 years the boy was sent to the Child Psychiatry Department because of learning difficulties and behaviour problems. Clinical examination revealed a boy with a delicate bodybuild with long arms and legs. There was hypogenitalism with small penis and hypoplastic scrotum. The nipples were small but normally set. Helght was $117 \mathrm{~cm}$ (Percentile 75) and weight $19 \mathrm{~kg}$ (Percentile 50). The bone age was 4 years as estimated on an X-ray of the left hand and wrist.

Chromosomal analysis on a peripheral blood lymphocyte culture revealed a $48, X X Y Y$ karyotype in all 25 examined cells.

Psychological testing revealed a total IQ of 74 on the WISC-A (verbal IQ 67, performantial IQ 86). There was a pronounced speech deficlt, poor memory and concentration. Movements were slow and clumpsy. Observation at the Child Psychiatric Department revealed a shy and timid boy with strong lack of self-confidence, and limited eye contact. But he presented also sudden outbursts of anger and reacted obstinately. $\mathrm{He}$ offered resistance when asked to perform and has a low frustration tolerance. This boy was quiet, oversensitive and cried easily.

Patient 3 (Figs. 2 a - b).

G.D. was the third born in a lower social class family with four children. Both parents were otherwise healthy and unrelated. His younger brother also presented a moderate mental retardation of unknown etiology. In the neonatal period feeding problems occurred and after the age of 3 years generalized epileptic seizures were noted. At the age of 6 years he was examined at the Department of Child Psychiatry because of speech delay and important behaviour problems, In addition to a moderate mental retardation a personality disorder was diagnosed with total loss of structure.

Chromosomal investigation was only performed at the age of 18 years during a systematic cytogenetic survey of an institutionalized population. The 48,XXYY constitution was found in all 22 cells of a peripheral blood lymphocyte culture. 
Clinical examination at that age revealed a longilign boy (height $185 \mathrm{~cm}$ (P97) - weight $75 \mathrm{~kg}$ (P75)) with normal secondary sexual characteristics. External genitalia were normal with small, soft testes. No evident dysmorphilc features were further noted but there was a discrete spasticity of the lower legs.

IQ testing was performed at the age of 6 and 18 years. The IQ results on the WISC-R were 52 (verbal IQ 52, performantlal IQ 64) and 55 (verbal IO 56 , performantial $\| Q 65$ ), respectively.

At younger age he presented aggressive and violent behaviour. He was admitted to at a Child Psychlatric Clinic. There was a lack of structure and self control. He always refused what he was asked to do. Autistic features were also observed. There was a communication disorder: no speech and no eye contact. After puberty these problems progressively disappeared. He now behaves as a pleasant and friendly boy with good social adaptation, but still remains a somewhat dominant person.

\section{Patient 4.}

V.B. was the second born in a family with four children. Parents were healthy and unrelated and family history is negative with regard to mental handicap and congenital malformations. Psychomotor development was retarded from the beginning and generalized epileptic attacks started from the age of 4 years on. Now, at the age of 25 years he was sent to the psychiatric department because of behaviour problems with fugues and incendlarism.

Clinical examination was unremarkable. Secondary sexual development was within normal limits and except for small soft tests external genitalia were normal. Height was $180 \mathrm{~cm}(P 75)$ and weight $69 \mathrm{~kg}(P 75)$.

In all 24 cells of a peripheral blood lymphocyte culture a $48, X \times \mathrm{XY}$ karyotype was found.

Psychological testing at that age revealed a total IQ of 56 (WAIS - verbal IQ 61 and performantial IQ 58). Behavioural problems, rapid alteration of mood and sleep disorders were quite common at home. After psychiatric admission these problems were explained by an atypical personality disorder, discord between the parents and heavy quarrels.

\section{DISCUSSION}

Up to now, data on 60 males with $48, X X Y Y$ karyotype were reported in the literature, and there is still a controversy whether the syndrome is associated or not with some typical physical features. In the present four 
boys the diagnosis of $48, X X Y Y$ syndrome was made at the ages of $4,6,18$ and 25 years respectively. Whereas the clinical stigmata were rather nonspecific in all four, except for a relatively ectomorphic, longlilgn habitus and small, soft testes with contrasting normal secondary sexual development in the two adults, they all came to the medical attention by the occurence of severe behavioural problems.

In their study, Borgaonkar et al. [3] reviewed the published data on 53 patients and they concluded that $48, X X Y Y$ boys are taller from early age on, compared to the growth parameters in a general population. In $30 \%$ of the boys height was above Percentile 90 and in $66 \%$ of them above Percentile 50. In an important number of patients chromosomal analysis was performed because of their tall stature. In non-adult males a delay in bone-age was found in $50 \%$ of them. Sexual characteristics and development were not different from those found in males with $47, X X Y$ karyotype. In general secondary sexual development was normal in adults with contrasting small, soft testes. Gynecomastia was present in $62 \%$ of the postpubertal patients and $18 \%$ had hypogenitalism.

Vigi et al. [4], in contrast, stated that adults with $48, X \times Y Y$ karyotype present clinical stigmata which are different from those found in 47,XXY Klinefelter syndrome. They noted a slight increase in height and weight and minor abnormalities of the external genitalia compared to the Klinefelter group. These stigmata, however, are too vague and atypical to allow for a differentiation with Klinefelter syndrome on a clinical basis.

In a previous study [5] we found that at least $50 \%$ of the $48, X X Y Y$ prepubertal boys present one or more clinically evident abnormalities which may be the indication for a chromosomal investigation l.e. hypogenitalism,

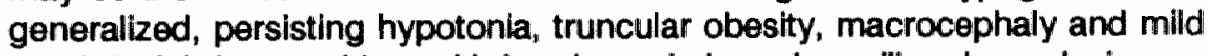
craniofacial dysmorphism with brachycephaly and maxillary hypoplasia.

Mental retardation was reported in all $48, X X Y Y$ patients described up to now, and was also present in the four males of this study. There was a widespread variation of $1 Q$, but all boys were proven to experience serious learning disorders. Moor [6] reviewed the $\mathrm{IQ}$ data of 31 males and calculated a mean IQ of 58 with spread between IQ 35 and IQ 80 . Borgaonkar et al. [3] concluded that $60 \%$ of the $48, X X Y Y$ males have an IO below $70,30 \%$ an IQ between 71 and 80 and $9 \%$ an IQ above 80 . Hier [7] was the first to report a higher performantial than verbal IQ in these males. We observed the same discrepancy in two of the four males of the present study. The IQ's of the present four boys were spread between IQ 75 and IQ 55 with a mean IQ of 64 . They were all mildly mentally retarded and had severe learning difficulties. Language development was severely delayed in all four and they showed obvious speech and articulation-problems. These findings are in agreement with the conclusions 
of Hier [7] and Garvey [8] who described an important delay in speech development in children with sex-chromosomal abnormalities.

The most important finding in the present study was the consistency of severe behavioural disorders in all four $48, \times X Y Y$ boys and the similarity of their psychological development. Three of the four boys had generalized eplleptic selzures in early childhood and were seen In child psychiatry between the age of 4 and 6 years, and the adult 25-year old patient was admitted in psychlatry. They all presented personality disturbances l.e. psychotic reactlons, total loss of structure and self-control, violent and impullsive reactions. It is interesting to note that in the two adult patients social integration became progressively possible after puberty, although outbursts of non-adaptive behaviour were still present in one of them at the age of 25 years. Behaviour problems and personality disorders were also noted in prevlous reports. Borgaonkar et al. [3] concluded that $83 \%$ of the $48, X X Y Y$ males had one or other form of aberrant behaviour, and that only $17 \%$ had a satisfactory soclal adjustement. In the patient reported by Vigi et al. [4] sudden bursts of anger and agressive reactions also persisted, despite he was quiet and timid in general.

The conclusion of the findings in the present 4 males with $48 . x \times Y Y$ karyotype is therefore that these males do not present distinctlve physical stigmata but that they show a similar psychosocial development and behavioural disturbances which may constitute the major indications for chromosomal analysis. The majority of XXYY males are mildly to moderately mentally retarded and are in addition at young age more susceptible to severe psychiatric problems like psychotic behavlour and/or neurotic reactions. Those difficulties are not present in other types of sex chromosome aneuploidies, and highly compromise social integration of these XXYY males.

\section{REFERENCES}

1. JACOBS P.A., MELVILLE M., RATCLIFFE S: : cytogenetic survey of 11,680 newborn infants. Ann. Hum. Genet., 1974, 37, 359-376.

2. MULDAL S., OCKEY C.H.: Double male: new chromosomes constitution in Klinefelters syndrome. Lancet, 1960, 2, 492 - 493.

3. BORGAONKAR D.S., HULES E., CHAR F.: Do the $48 \times X Y Y$ males have a characteristic phenotype? Clin. Genet., 1970, 1, 272-293.

4. VIGI V., RIICA A., GUENINI P. et al.: Endocrine function and dlagnostic problems in a prepubertal case of 48,XXYY. J. Genet. Hum., 1978, 26, 411-417. 
5. KLECZKOWSKA A., FRYNS J.P., VAN DEN BERGHE H.: X-chromosome polysomy in the male. Hum. Genet., 1988, 80, 16-22.

6. MOOR L: Niveau Intellectuel et polygonosomle. Rev. Neuropsych., 1967, 15, 325-348.

7. HIER D.D., ATKINS L, PERLO V.P.: Learning disorders and sex chromosome observations, J. Ment. Def. Res., 1980, 24, 17-26.

8. GARVEY M., MUTTON D.E.: Sex chromosome observations and speech development. Arch. Dis. Childh., 1973, 48, 937-941. 


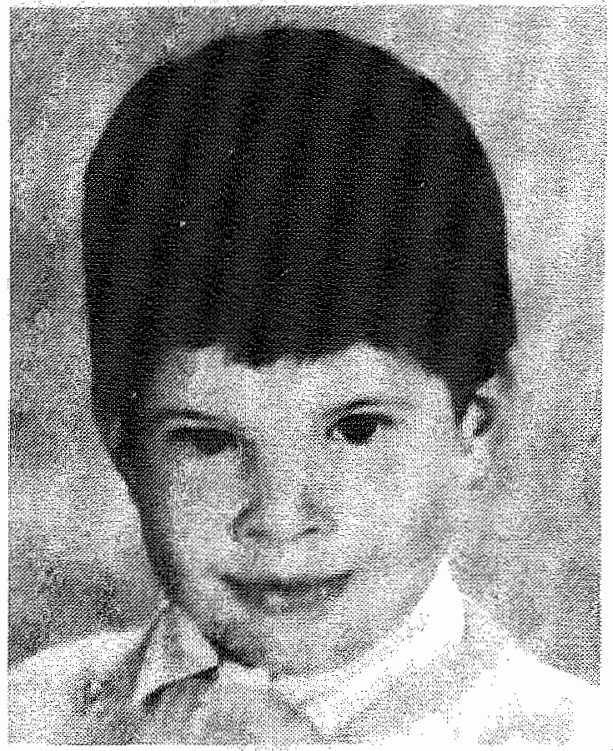

Fig. 1. The facies of patient 2

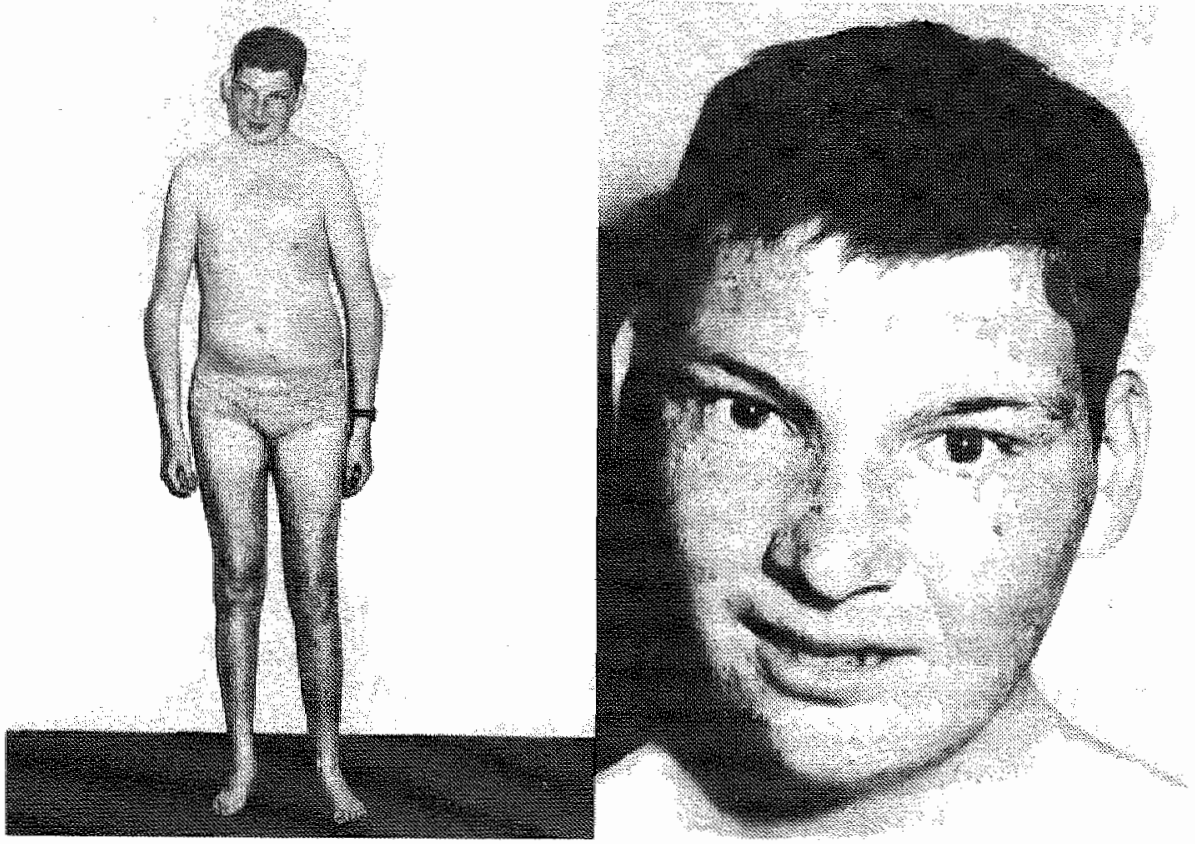

Fig. 2. The physical appearance (a) and the facies of patient 3 


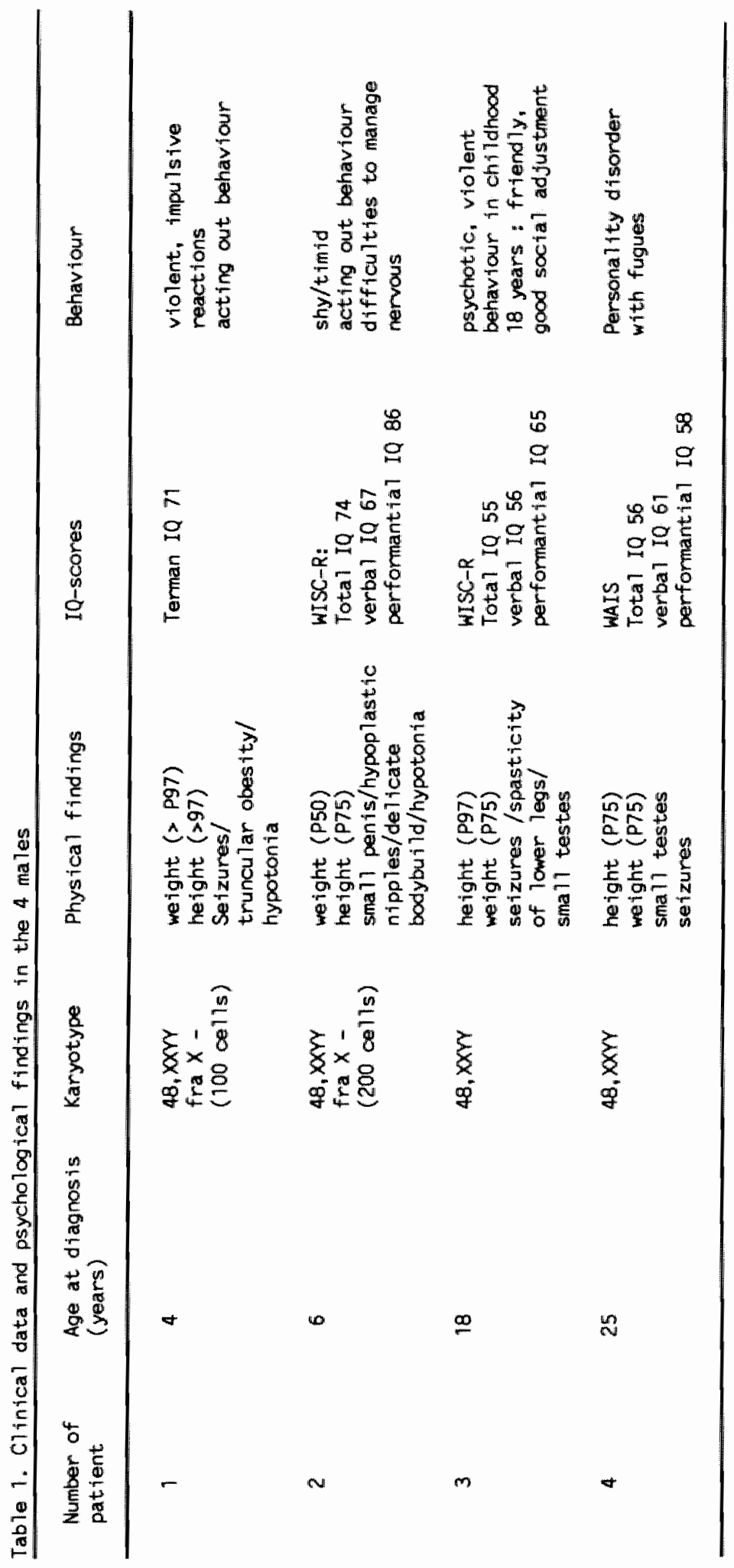


a

$\therefore \quad \therefore$

?

$\because \quad \vdots$

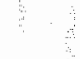

i 
4. THE FEMALE WITH QUADRUPLO-X SYNDROME:

Clinical and psychological findings in three prepubertal girls 
Clin. Genet, 1991, in press

\title{
THE FEMALE WITH QUADRUPLO-X SYNDROME:
}

Clinical and psychological findings in three prepubertal girls

\author{
M. BORGHGRAEF, J.P. FRYNS, H. VAN DEN BERGHE
}

Centre for Human Genetics, U.Z. Gasthuisberg, Herestraat 49, B-3000 LEUVEN (Belgium).

\section{ABSTRACT}

In the present paper we give follow-up data on the physical and psychological development in three young, prepubertal patients with $48, X \times X X \times$ syndrome and compare these findings with the literature data. None of these three young $48, X X X X$ girls presented a clinically recognisable syndrome; in contrast they were mildly mentally retarded with similar traits of character and behaviour.

Key words: Sex-chromosomes; $X$-chromosome; $48, X X X X$; mental retardation

\section{INTRODUCTION}

Up to now, a limited number of studies have reported on the physical and psychological development of, mostly adult, patients with several types of sex-chromosomal abnormalities. Leonard et al. (1971), Eller et al. (1971) and Valentine et al. (1971) demonstrated an increased incidence of mild developmental delay and behavioural problems from early childhood on. The $48, X X X X$ syndrome is among the rarest sex-chromosomal abnormalities 
whth unknown prevalence rates. After the first description by Carr et al. (1961) no more than 40 patlents have been reported. In the present paper we give follow-up data on the physical and psychologilcal development in three young, prepubertal patients with $48, X \times X X$ syndrome and compare these findings with the literature data.

REPORT OF PATIENTS (for summary see Table 1)

\section{Patient 1}

K.V.G. Was the second child of healthy, unrelated parents. Dellvery, at the expected term was normal. Birthweight was $3 \mathrm{~kg} 300$ and tength $47 \mathrm{~cm}$. There was relattve oligohydramnios. Because of the presence of massive oedema of the dorsum of hands and feet, chromosomal analysis was performed. In all 25 cells of a peripheral lymphocyte culture a $48, X X X X$ karyotype was found. No major medical problems were noted in the first years of life. A the age of 4.5 years height was $105 \mathrm{~cm}$ (P25-P50), weight 14 $\mathrm{kg}$ (P25-P50) and head circumference $49.5 \mathrm{~cm}$ (P50). Clinical examination was normal except for discrete resthypotonia, small hands and feet, relative truncular obesity and hypoplastic labia majora. The palate was high-arched and there was hyperpllosity of the presacral reglon.

Psychological findings: The early psychomotor development was mildy delayed and, from the beginning, more pronounced for the motoric milestones. At the age of 16 months she functioned at a mental age of 13 months and a motor age of 8 months, and at the age of 27 months mental age was 21 months and motor age 16 months. At the age of 4 years 5 months IQ evaluation on the Stutsman test revealed an IQ of 90 with the lowest performances on verbal items and fine motor skills. From that age on she was integrated in a normal infant school. Speech development started only after the age of 3 years, and at the age of 4.5 years she presented still an obvious delay with important speech defects. No behavioural problems were at note although she was anxious in new situations. She was shy and timid but, in general, pleasant and cooperative.

\section{Patlent 2}

E.D. was the third child of healthy, unrelated parents. Pregnancy and delivery were normal. Birthweight and length were $3050 \mathrm{~g}$ and $48 \mathrm{~cm}$ respectively. In the postnatal period extreme hypotonia and recurrent 
bronchlal infections were noted. At the age of 3 years a chromosomal investigation was performed because of a mild psychomotor delay associated with hypotonia, hyperlordosis, relative truncular obesity and clinodactyly of the Vth fingers. A 48, XXXX karyotype was found in all 30 cells of a peripheral lymphocyte culture. At the age of 5 years 3 months height was $115.5 \mathrm{~cm}$ (P75), weight $22 \mathrm{~kg}$ (P75) and head clrcumference 48 cm (P50).

Psychological findings: In the postnatal period she was a quiet and pleasant baby. The parents noted a mild delay of psychomotor development from the beginning: she could sit without support at the age of 9 months and walked at the age of 25 months. She attended a normal infant school untll the age of 6 years and is now Integrated In a special school for mildly' mentally retarded. $1 Q$ evaluation at the ages of 3 and 5 years respectively revealed IQ's of 71 (Stutsman test) and 67 (Terman test). She had wordfinding problems and poor fine motor skills. She was somewhat inhibited in language and dared not always to answer questions. She also has some speech defects and needed intens speech therapy. She was timid and reacted anxiously in new situations. She prefered to play alone, mostly in outside activities.

\section{Patlent 3}

V.V. was the first child of healthy, unrelated parents. Pregnancy and delivery were normal with a birthweight of $2900 \mathrm{~g}$. Psychomotor delay was noted from the beginning. She could sit without support at the age of 20 months and walked at 26 months. She was integrated in a normal school untll the age of 7 years. At the age of 8 years she attended a special school for the mildly mentally retarded. Cinicall examination revealed evident resthypotonia and hyporeflexia, and relative mandibular prognathism. Height was $145.5 \mathrm{~cm}$ (P50), weight $31.3 \mathrm{~kg}$ (P25) and head clrcumference $51.5 \mathrm{~cm}$ at (P25-50) the age of 11 years. Chromosomal investigation revealed a $48, X X X X$ karyotype in all 30 cells of a peripheral blood lymphocyte culture.

IQ evaluations at the age of 6 years and 11 years revealed IO's of 75 (Stutsman test) and 72 (Terman test). Relative weaknesses were seen on verbal items, fine motor skills and spatial judgement. There was an important general delay in speech development and articulatory problems like rhotacism, omissions, interdentalism. At the age of 8 years she had a language level of $48 / 12$ years. She was extremely timld and avoided eyecontact, but at home she was cooperative and obedient. She also reacted anxiously in a new environment. 


\section{DISCUSSION}

The three young $48, \times \times \times \times$ girls reported in this study did not present a clinically recognizable dysmorphic syndrome. Growth and general physical development were normal. Nevertheless, a remarkable finding was the pronounced hypotonia at birth in all three, which regressed only after the age of 2 to 3 years and was responsible for a serious delay of motor development. Other clinical signs at note were: relative truncular obesity in patients 1 and 2, small hands and feet, high-arched palate, hypoplastic labla majora in patient 1 , hyporeflexia and mandibular prognathism in patient 2 , hyperlordosis and clinodactyly of the Vth finger in patient 3.

The physical development and facial appearance of $48, X X X X X$ females reported in the literature is quite heterogeneous. Some authors (Park et al., 1970; Pena et al., 1974; Renick et al., 1972; Telfer et al., 1970) did not recognize a well-defined phenotype in their patients and they concluded that the somatic effect of the two extra X-chromosomes in these females is not great. The patients reported by Pena et al. (1974) and Renick et al. (1972) presented a growth curve below the third percentile, and truncular obesity and severe hypotonia, as seen in the present study, were noted by Park et al. (1970) and Pena et al. (1974). In four postpubertal patients we noted (Fryns et al., 1983) a delay in staturoponderal development and incomplete maturation of secondary sexual characteristics. On the contrary, de Grouchy et al. (1979) described a typlcal facial dysmorphism in the $48, X X X X$ syndrome with coarse face, low hair implantation, hypertelorism, epicanthus and short neck, resulting in a general appearance resembling trisomy 21. This is thus in contrast with the findings in the present study and in the majority of the previous reports on $48, X \times X X X$ females.

The psychological development and profile was very similar in the present three young $48, X X X X$ girls. They were all three socially well integrated and IQ measurements varied between 67 and 90 (low-normal range to mild mental retardation). They all presented a serious delay of gross motor skills related to the hypotonia and had also problems with the acquisition of fine motor skills. Speech defects and articulatory problems were observed in all three. They behaved as pleasant, cooperative girls but were shy and timid in new situations. This is in good agreement with the findings in other patients : mild mental retardation with poor fine motor skills and lower verbal performances seem to be the most common general features. in their study Nielsen et al. (1977) reported a variation of IQ between 30 and 82, with a majority of patients between 55 and 75 , and this was also observed by Park et al. (1970), Renick et al. (1972), Pena et al. (1974), de Grouchy ot al. (1979). 
In older, postpubertal patients we found IQ's below 55 (Fryns et al. 1983), and they presented the greatest delay in motor skills and speech development. The question can therefore be raised whether a decline in $1 Q$ with age may be a more general characteristic in this $X$-polysomy syndrome.

The majority of $48, X \times X \times$ patients have been described as pleasant, friendly and without important emotional or behavioural disturbancies. In four adults we noted episodes of shyness and anxiety (Fryns et al., 1983) and Park et al. (1970) also noted a tendency to excitement and anxiety in their patients. Telfer et al. (1970) reported a 48,XXXX karyotype in a patient with childhood onset schizophrenia The present data, however, indicate that schizophrenic behaviour is not a general, specific finding and that it is premature to conclude that a schizophrenic predisposition may be related with the $48, X X X X$ syndrome.

The findings in the present study and the literature data show that $48, \times \times \times X$ patients are mildly mentally retarded with a quite variable, non specific phenotype and that they have quite similar traits of character and behaviour.

\section{REFERENCES}

Carr, D.H., H.L. Barr \& E.R. Plunkett (1961). An XXXX sex chromosome complex in two mentally defective females. Canad. Med. Ass. J. 84, 131. de Grouchy, J., J. Violatte, M. Chain-Collin Roubin \& C. Turleau (1979). Le syndrome $48, X X X X$. Arch. franc. Pediatr. (Suppl.) 36, XLI-XLVII.

Eller, E., W. Frankenburg \& H. Puck (1971). Diagnosis in newborn infants with X-chromosomal abnormalities. Pediatrics 47,681 .

Fryns, J.P., A. Kleczkowska, P. Petit \& H. Van den Berghe (1983).

$x$-chromosome polysomy in the female. Personal experience and review of the literature. Clin. Genet. 23, 341-349.

Leonare, M.F., G. Landy \& R.M. Ruddle (1984). Early development of children with abnormalities of the sex chromosome. A prospective study. Pediatrics 54:208, 1974.

Nielsen, J., A. Hamna, F. Chisharisen \& K. Rasmussen (1977). Women with tetra $X$. Hereditas 25, 151-156.

Park, I.J., J.E. Tyson \& Jones H.W. Jr. (1970). A 48, XXXX female with mental retardation. Report of a case. Obstet. Gynecol. 35, 248-252.

Pena, S.D.J., M. Ray, G. Douglas, E. Loadman, \& J.L. Hamerton (1974). A 
48, $\times 0 \times \times$ female. J. Med. Genet. 11, 211-215.

Renilck, E.G. (1972). A female with $X X X X$ sex chromosome complement. J. Ment. Def. Res. 16, 84-89.

Telfer, M.A. C.E. Richardson, J. Helinken \& G.F. Smith (1970). Divergent phenotypes among $48, X \times X X$ and $47, X \times X$ females. Am. J. Hum. Genet. $22,326-335$.

Valentin, G.H., M.A., Mc Celland \& F.R. Sergavich (1971) The growth and development of four XYY infants. Pediatrics 48, 583.

Address :

J.P. Fryns

Centre for Human Genetics

Herestraat 49

B-3000 Leuven, Belglum 


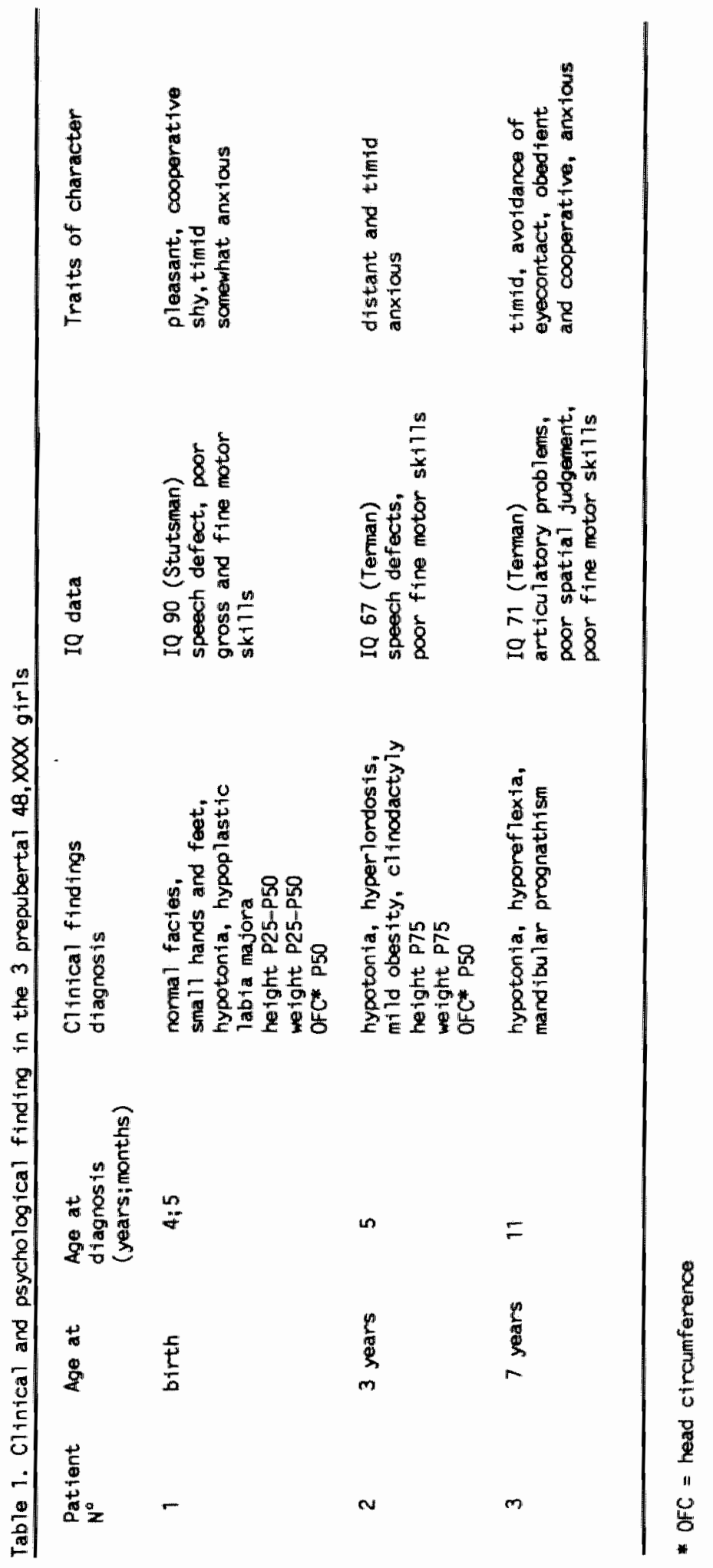





\section{DISCUSSION AND CONCLUSION}

\section{Sex-chromosome Aneuploidies}

Up to now, a number of prospective and longitudinal studies (Robinson et al. 1986) have reported precise data on patients with the more common, classical seX-chromosome aneuploidles e.g. 45, $X, 47, X X X$ and $47, X X Y$. Few reports, however, have dealt with the physical and psychological development in children with more rare sex-chromosome abnormalities $(48, X X X X, 48, X X Y Y$ and $49, X X X X Y$ ) (Leonare et al. 1984, Moor 1967, Nlelsen et al. 1977).

In this part we reported the follow-up data of clinical observation, registration and psychometric testing in 8 young males with the $49, X X X X Y$ syndrome, 4 males with the $48, X X Y Y$ syndrome and 3 gills with 48 , XXXX karyotypes. An interesting finding was the specific profile of each of these sex-chromosome abnormalities as to the individual physical and psychological development. The $48, X X X X Y$ boys presented mild to severe mental retardation and in two of them we noted a decline in intellectual function with age. Mild emotional problems l.e. shyness, anxlety, avoldance of eye contact and low frustration level were noted in all of them, but they all reached a satisfying level of adaptive functioning. On the contrary, the $48, X X Y Y$ boys performed at a higher intellectual level but all manifested serious behavioural disorders and personality disturbances. These difficulties highly compromise their social integration and education. They were all admitted for one or several observation periods in psychiatric hospitals and needed continuing intense guidance.

The three young prepubertal girls with the $48, \times 1 X X X$ syndrome showed similarities in cognitive development and behavioural characteristics with the group of $49, X \times X X Y$ males. They were mildly to moderately mentally retarded and were shy, timid and somewhat anxious.

The present study gives further evidence that the risk for mental retardation and physical defects in males with the "rare" sex-chromosome aneuploidies primarily increase with the number of extra X-chromosomes, and only in a second order with the number of extra Y's (Moor 1967). The boys with a $48, X X Y Y$ karyotype, however, showed a higher incidence of, mostly severe, behavioural problems and personality disorders. These problems may probably be due to the occurrence of generalized epileptic selzures in early childhood in some of these boys, and is likely more related with the extra $Y$ than with the extra $X$ chromosome. The detection in the early sixtles 
(Jacobs et al. 1965, Kessler \& Moos, 1970) of a high prevalence of malle sex chromosomal aberrations In populations of penal settings made this toplc highly controversial and emotionally loaded.

The study of a possible relationship between psychopathological abnormalitles and sex chromosome aneuploidies is particularly fascinating because of the presence of behavioural dysfunctions and psychiatric symptoms in a number of them. Up to now, the majority of data were provided by retrospective studies. Prospective studies are of outermost importance towards a better understanding of the pathogenesis of these psychosocial disorders in these chromosomal syndromes and are a major instrument to clarify the relationship between the $X$ and $Y$ chromosomes and physical, cognitive and behavioural features.

\section{References}

Jacobs P.A., Brittain R.P., Mc Clermont W.F. Agressive behavior, mental subnormality and the XYY male. Nature 208, 1351, 1965.

Kessler S., Moos R.H. The XYY karyotype and criminality: A review. J. Pediatr. Res. 7, 153-170, 1970.

Leonare M.F., Candy G., Ruddle R.M. Earty development of children with abnormalities of the sex chromosome. A prospectlve study. Pedliatrics $54,208,1984$.

Moor L. Niveau intellectuel et polygonosomie. Rev. Neuropsych. 15, 325348, 1967.

Nielsen J., Hamma A., Chishausen F., Rasmussen K. Women with tetra X. Hereditas 25, 151-156, 1977.

Robinson A., Bender B.G., Borelli J.B., Puck M.H., Solbenblatt J.A. Winter J.S.D. Sex chromosomal aneuploidy: prospective and longitudinal studies. Birth Defects Original Article Series, 22, 23-71, 1986. 


\section{B. AUTOSOMAL SYNDROMES}

\section{INTRODUCTION}

After the description of the classical numerical chromosomal abnormalities in the pre-banding period, the introduction of the different banding techniques lead to the recognition and individualisation of more than 120 other mostly structural autosomal anomalies, partial monosomies and trisomies. This postbanding chromosome technology contributed until now to the cytogenetic diagnosis in 2 to $3 \%$ of the mentally retarded. Although this percentage is low, this correct diagnosis led to the detection of high risk familles, and made genetic counseling and prenatal diagnosis in phenotypically normal carriers possible. During the same period a number of diseases, known for many years and considered to be genetically determined, have been shown to be associated, at least in some instances, with chromosome deletions which can be extremely small, at the limit of resolution. This was made possible by the introduction of high resolution banding techniques as example. In approximately half of the patients with Prader-Willi syndrome a variety of rearrangements involving chromosome 15 (15q11-13 deletion) have been described. Untll now, the dlagnosis of Prader-Willi syndrome was essentially based on the association of more or less typical clinical features: hypotonia and feeding difficultles, hypogonadism and cryptorchidism, mental retardation, obesity, hyperphagia and short stature. It is likely that with the help of better high resolution techniques small 15q11 deletions will be discovered in all patients with typical Prader-Willi syndrome, and that high resolution banding techniques will become a conditio sine qua non in the final diagnosis of this syndrome.

In the Center of Human Genetics a large number of patients with different types of autosomal chromosomal rearrangements were diagnosed with the respective chromosomal banding techniques (see infra p. 138).

From the beginning it became evident that most, if not all, partial autosomal trisomies and monosomies are associated with a clinically recognisable syndrome from birth on. Mental retardation is present in all patients, and this developmental delay, mostly moderate to severe, is accompanied by behavioural problems. Up to now, little is known about the psychological profile of these different autosomal syndromes and we revised the question whether, as in the fragile $X$ syndrome, these types of chromosomal abnormalities are associated or not with specific and early recognisable disturbances in psychomotor development and psychological profile. 
We present here data on three different chromosomal syndromes, ring chromosome 15 syndrome, partlal and full trisomy 8 and Prader-Wili syndrome. Ring chromosome 15 is the only autosomal ring chromosome in which a constant clinical recognisable syndrome (severe pre- and postnatal growth retardation, and typical craniofacial appearance with triangular face, micro-retrognathism and oldish appearance) is found, and in contrast with other ring chromosomes not assoclated with severe developmental retardation. Trisomy of chromosome 8 is a rare autosomal trisomy syndrome with normal life prognosis, slight to moderate mental retardation, a triangular, Elfin-like facles and deep palmar grooves on hands and feet. The Prader-Will syndrome is a newly discovered partial autosomal deletion syndrome (deletion of bands 15q11-15q13) in which severe neonatal hypotonia and feeding difficulties are progressively replaced by hyperphagia, obesity and important emotional and psychological disturbances.

Technleal note (see also appendix)

\section{Chromosomo studies}

In all examined patlents atandard procedures were followed for culturing and harvesting. As a rule all studies were done on lymphocytes, but in some cases fibroblasts were also investigated.

In all karyotyped patients ohromosomal analysis was performed with Giemsa banding and Quinacrine fluorescence (Figs. 1 and 2, p. 205 in appendix). In the patients with chromosomal abnormalities additional banding techniques ( $C$ - and R-banding. Figs. 3 and 4, p. 206 in appendix) and prometaphase banding (Fig. 5, p. 207) were performed whenever they were necessary to clarify the chromosomal abnormality. 
2. PSYCHOLOGICAL PROFILE AND BEHAVIOURAL CHARACTERISTICS IN 12 PATIENTS WITH PRADER-WILU SYNDROME 
. 


\title{
PSYCHOLOGICAL PROFILE AND BEHAVIOURAL CHARACTERISTICS IN 12 PATIENTS WITH PRADER-WILLI SYNDROME
}

\author{
by M. BORGHGRAEF, J.-P. FRYNS, H. VAN DEN BERGHE*
}

\begin{abstract}
Summary: Psychological profile and behavioural characteristics in 12 patients with Prader-Willi syndrame: In the present study medical, psychological and behavioural aspects in 12 patients with Prader-Willi syndrome (PWS), aged between 13 months and 28 years are presented. In half of the patients the diagnosis of PWS was made before the age of one year. The contribution of cytogenetic investigations with the detection of a $15 q 11$ deletion in half of the PWS patients is discussed. In the evaluation of the intellectual performances IQ levels were spread between 45 and 95 with a mean $1 Q$ of 54 . A specific behavioral profile in all patients with characteristic fluctuations with age was observed. Rapid changes in behaviour increased with age and after puberty, mostly related with withoiding of food. The present study reinforces the importance of early diagnosis in the PWS with adequate and intelligible information towards the parents. It may prevent the dramatic obesity which leads to severe physical problems and psychological burdens in PWS adolescents and adults.
\end{abstract}

Résumé: Le profil psychologique et les caractéristiques comportementales chez 12 malades atteints de syndrome de Prader-Will: Dans cette étude, nous présentons les aspects médicaux, psychologiques et comportementaux chez 12 malades atteints de syndrome de Prader-Willi, âgés entre 13 mois et 28 ans. Chez la moitié de ces patients, le diagnostic de syndrome de Prader-Willi a êté posé avant l'áge d"un an. La contribu.tion de la cytogénétique dans le diagnostic reposant sur la détection d'une délétion $15 q 11$, retrouvée chez $50 \%$ des malades, est discutée. Le quotient intellectuel variait entre 45 et 95 , avec une moyenne de 54 . Un profil comportemental typique est retrouvé dans tous les cas, montrant une fluctuation typique avec l'âge. En effet, avec la puberté les problèmes comportementaux augmentaient considérablement, et étaient le plus souvent en rapport avec l'instauration d"une ou autre forme de thérapie diététique. L'importance d'un diagnostic précoce accompagné d"une information compréhensible l' l'egard des parents est confirmée par la présente étude. 11 permet d"éviter une obésité dramatique et ses conséquences psychologiques chez les adolescents et adultes.

Key-words: Prader-Willi syndrome - Chromosome $15-$ Mental retardation.

Mots-clés: Syndrome de Prader-Willi - le chromasome 15 - Retard mental.

\section{INTRODUCTION}

After the first description by Prader, Labhart and Willi in 1956 (1) more than 400 patients with this MCA/MR syndrome have been reported in the medical literature. The syndrome is characterized by four cardinal symptoms which are evident from early life on i.e. hypotonia, hypogonadism, mental retardation

* Center for Human Genetics, University of Leuven, Belgium. (hypomentia) and obesity, and therefore some authors have used the term HHHO syndrome in the past (2). The recent cytogenetic finding of an interstitial $15 q 11$ deletion in about half of the PWS patients was an important additional stimulus towards a greater interest in this syndrome $(3,4)$. Despite this increasing knowledge, mostly on the medical aspects of the syndrome, many important questions still remain unanswered. Estimations of the incidence of the Prader-Willi syndrome (PWS) vary greatly from author to author i.e. from 1:20.000 up to 
a)

Figures 1 : Patient 11 at the age of 2 months (a), 2 years (b), 4 years (c) and 27 years (d).

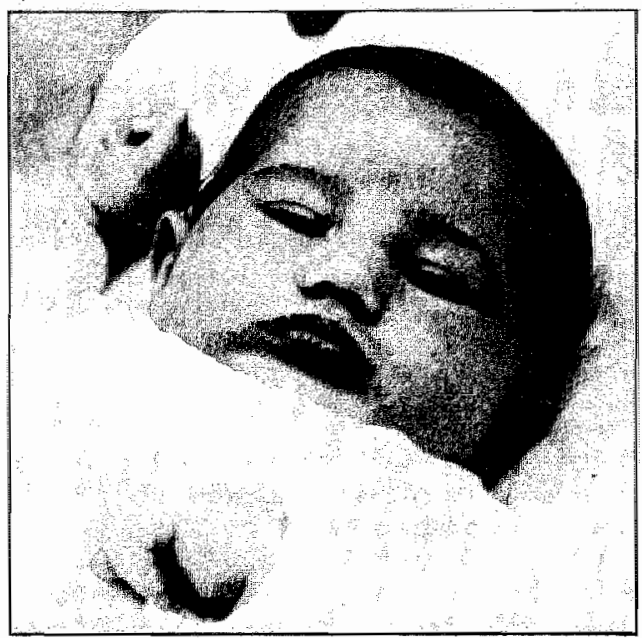

b)

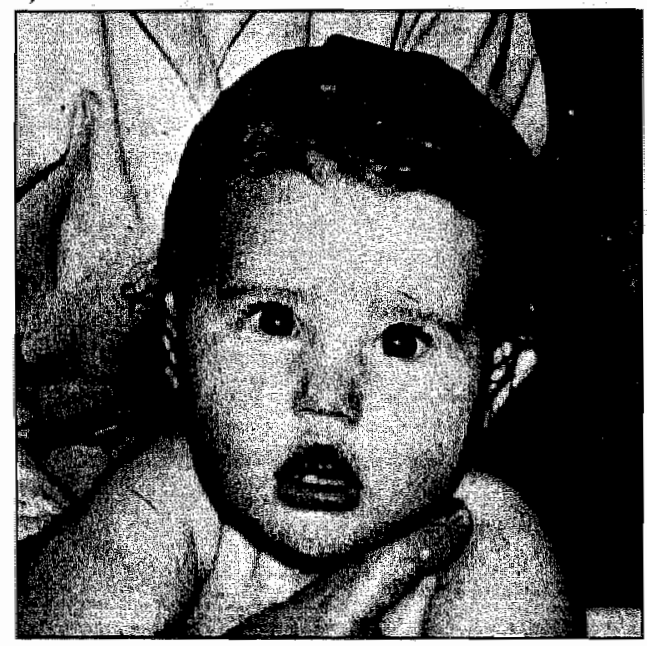

$1: 200.000$ livebirths. Whereas patients are diagnosed at younger and younger ages, care and management of PWS children and adults remain very difficult. Behavioural and psychological problems are frequent, if not consistent, findings in PWS patients.

\section{MATERIAL AND METHODS}

The purpose of the present study was to delineate more accurately the developmental and behavioural profile in PWS patients. We observed and evaluated 12

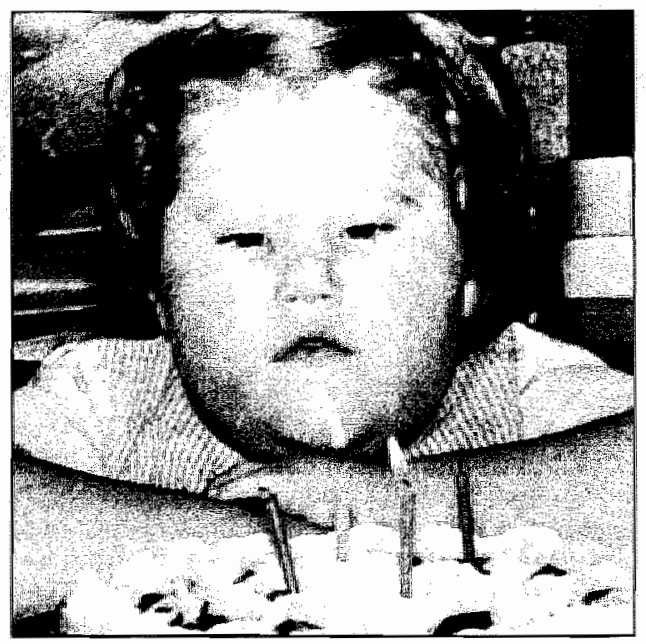

d)

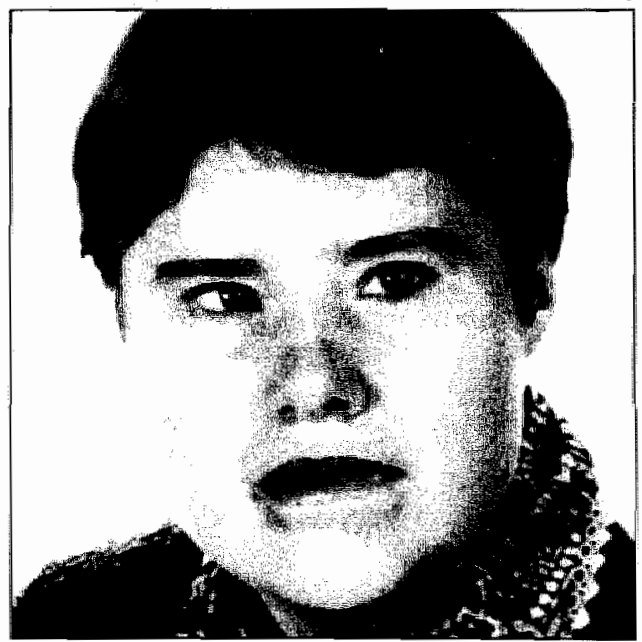

PWS patients diagnosed at the Centre for Human Genetics and aged between 13 months and 28 years, and obtained complete anamnestic data on medical antecedents and developmental milestones from parents and professionals taking care of them.

\section{General data}

All patients presented the typical clinical characteristics of the syndrome (see Figures 1 and 2a,b). Table 1 gives detailed data on present age, birthweight and 
Figures $2 a$ : Patient 7 at the age of 6 years.

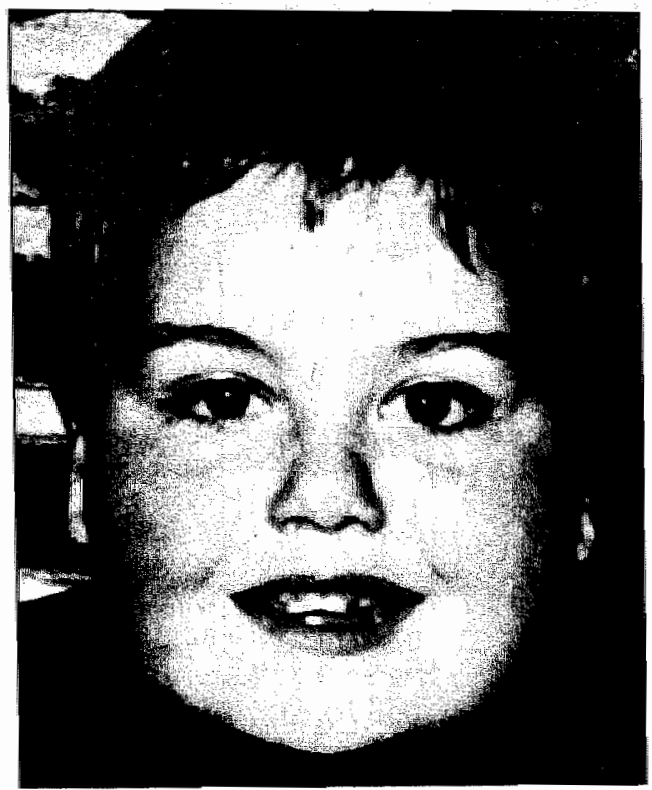

Figure $2 b$ : The typical craniofacial stigmata in patient 3 at the age of 14 months.

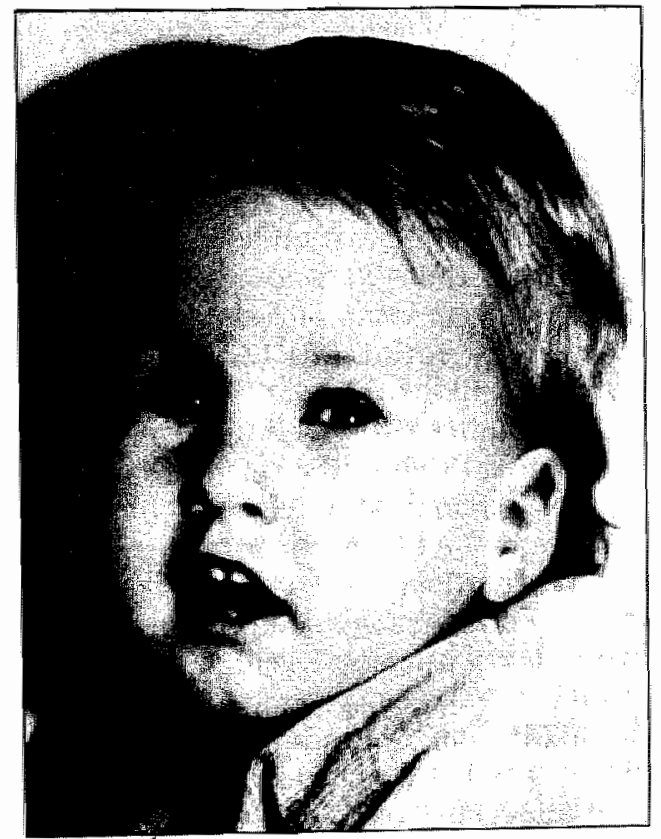

length, present weight and length, cytogenetic findings, mental performance and school level. The mean birthweight was $2760 \mathrm{gr}$ (data on 11 patients) and the mean length at birth $49 \mathrm{~cm}$ (data on 9 patients). It is interesting to note that length and weight were at the third percentile and far below the third percentile respectively in the three patients younger than two years 6/12. Two boys, $410 / 12$ years and 6 years old, respectively, were at the normal infant school, one boy $(6$ $6 / 12$ years) was in a special school for the mildly mentaliy retarded (type 1 ), four other children and adolescents (between 6 $10 / 12$ years and $176 / 12$ years) were at a special school for the moderately mentally retarded (type 2) and the adult females were at an occupational day center. In 9 patients prometaphase chromosome studies were performed and in live of them a $15 q 11$ deletion was found, a typical $15 \mathrm{q} 11$ interstitial deletion in four patients and a de novo 11 qter/15q 11 translocation in the fifth patient.

\section{Medical antecedents and early psychomotor development}

Table 2 summarizes the anamnestic data on medical antecedents and early psychomotor development. Pregnancy was without major complications in all children and the first intrauterine movements were felt at the normal, expected time in 11 of the 12 pregnancies. Fetal activity, however, was feeble and one mother experienced fetal movements very late (28 weeks) and extremely weak. Massive polyhydramnios, as a first intrauterine symptom of swallowing problems, was a major complication in $70 \%$ of the pregnancies and was the cause of preterm labour in $40 \%$ of them. Severe hypotonia, absence of crying and/or resuscita tion problems were constant perinatal problems. In the first months of life swallowing difficulties and severe feeding problems were noted in $90 \%$ of the PWS newborns and this resulted in failure to thrive with growth and weight curves far 
Table I:

\begin{tabular}{|c|c|c|c|c|c|c|c|c|c|}
\hline $\begin{array}{l}\text { Pailient } \\
\text { Number }\end{array}$ & sex & $\begin{array}{l}\text { Fresent } \\
\text { Ange } \\
\text { (monthos } \\
\text { yeargi }\end{array}$ & $\begin{array}{l}\text { Hitrih } \\
\text { (geight } \\
\text { (gramis) }\end{array}$ & $\begin{array}{l}\text { Birth } \\
\text { lenght } \\
\text { (cmis) }\end{array}$ & 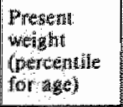 & $\begin{array}{l}\text { Present } \\
\text { letughi } \\
\text { (percendle } \\
\text { for abo) }\end{array}$ & $\begin{array}{l}\text { Cyrogerienic } \\
\text { rinding }\end{array}$ & $\begin{array}{l}\text { mental } \\
\text { performance }\end{array}$ & Schwoll tewel \\
\hline 1 & $=$ & $13 \mathrm{mo}$ & 2950 & 5 & $<\mathrm{P} 3$ & P3 & $\begin{array}{l}\text { de novo } \\
\text { t(11:15) (qter,qli) }\end{array}$ & $\begin{array}{l}\text { m.d.a.: } 9 \text { mo } \\
\text { mild M.R. }\end{array}$ & \\
\hline 2 & 8 & $15 \mathrm{mo}$ & 2870 & $\$ 2$ & $<\mathbb{P} 3$ & P3 & $\begin{array}{l}15 q 12 \text { interstitial } \\
\text { delletion }\end{array}$ & $\begin{array}{l}\text { m.d.a.: } 11 \text { mo } \\
\text { mild M.R. }\end{array}$ & \\
\hline 3 & $\sigma$ & 28 mo & 2950 & 52 & $<\mathrm{P} 3$ & P3 & dell(15)(ql1) & $\begin{array}{l}\text { m.d.a.: } 17 \mathrm{mo} \\
\text { moderate M.R. }\end{array}$ & \\
\hline 4 & $\sigma^{\prime}$ & 4 y $10 \mathrm{mo}$ & 2550 & 45 & P50/P75 & P10/P25 & $\operatorname{dell}(15)(q 11)$ & $\begin{array}{l}\text { Total IQ: } 92 \\
\text { milld M.R. }\end{array}$ & $\begin{array}{l}\text { normal infant } \\
\text { school }\end{array}$ \\
\hline 5 & $\infty$ & $6 y$ & 3250 & 52 & $P 90$ & P50 & not examimated & Total 1Q. 65 & $\begin{array}{l}\text { normal infant } \\
\text { school }\end{array}$ \\
\hline 6 & $0^{\circ}$ & 6 y $6 \mathrm{mo}$ & 3400 & 48 & P25 & P25 & normal & $\begin{array}{l}\text { Total IQ: } 78 \\
\text { mild M.R. }\end{array}$ & $\begin{array}{l}\text { Special } \\
\text { school type } 1\end{array}$ \\
\hline 7 & $0^{\prime}$ & 6 y $10 \mathrm{mo}$ & 3200 & 49 & $>\mathrm{P} 97$ & P5O & normal & $\begin{array}{l}\text { verbal IQ: } 68 \\
\text { mild M.R. }\end{array}$ & $\begin{array}{l}\text { Special } \\
\text { school type } 2\end{array}$ \\
\hline 8 & $q$ & $8 y$ & 2800 & 48 & P9o & n.d & not examined & $\begin{array}{l}\text { Total IQ: } 62 \\
\text { moderate M.R. }\end{array}$ & $\begin{array}{l}\text { Special } \\
\text { school type } 2\end{array}$ \\
\hline 9 & 웅 & $14 y$ & 3300 & n.d. & $<\mathrm{p} 50$ & P10 & not examined & $\begin{array}{l}\text { Total IQ: } 61 \\
\text { moderate M.R. }\end{array}$ & $\begin{array}{l}\text { Speciall } \\
\text { school type } 2\end{array}$ \\
\hline 10 & ó & 17 y $6 \mathrm{mo}$ & 2900 & 47 & P75/P90 & P25 & $\operatorname{del}(15)(q 11)$ & $\begin{array}{l}\text { Total IQ: } 50 \\
\text { moderate M.R. }\end{array}$ & $\begin{array}{l}\text { Special } \\
\text { school type } 2\end{array}$ \\
\hline 11 & $q$ & 27 y $5 \mathrm{mo}$ & n.d? & n.d. & P9O & $<\mathrm{P} 25$ & normal & $\begin{array}{l}\text { Total IQ: } 69 \\
\text { mild M.R. }\end{array}$ & $\begin{array}{l}\text { Occupational } \\
\text { day centre }\end{array}$ \\
\hline 12 & Q & 28 y $8 \mathrm{mo}$ & 3600 & n.d. & $>\mathrm{P} 90$ & $<\mathrm{P} 25$ & not examinated & $\begin{array}{l}\text { Total IQ: }<50 \\
\text { moderate M.R. }\end{array}$ & $\begin{array}{l}\text { Occupational } \\
\text { day centre }\end{array}$ \\
\hline
\end{tabular}

m.d.a.: mean developmental age, M.R.: mental retardation.

below the third percentile. After the age of 2 to 4 years the weight curve changed dramatically in all patients in whom the PWS diagnosis was not yet made at that age. In patients with early diagnosis awareness of the parents and teachers about this obesity problem resulted in a much better preventive control of weight and eating practices of the patients and their families. Fig. 3a shows the weight curve in a boy diagnosed as PWS shortly after birth. Even after later diagnosis e.g. at the age of 3 years weight control was a success in some patients (Fig. 3b) whereas in others the overweight problem remained unchanged (Fig. 3c) or even worsened and became life threatening even after diagnosis and information towards parents and teachers or other professionals. Early psychomotor development (see Table IIb) was severely delayed in all patients. The majority of the early gross motor milestones were not reached before the age of one year. The average age for independent sitting was 12 to 15 months and for walking 24 to 30 months. Fine motor abilities were acquired very slowly and some of them, like cutting with scissors, were acquired in only half of them. Even later in life problems of unstable gait persisted in most patients, and are most pronounced in the group with severe overweight problems. Walking on long distances was nearly impossible, also in the adolescent and adult patients, who mostly needed a wheelchair to move in their direct environment. Training of tidiness was started at normal age and was reached in general from the age of 4 years on. Speech development was retarded in 
Table II: Anamnestic data on medical antecedents (a) and psychomotor milestones (b).

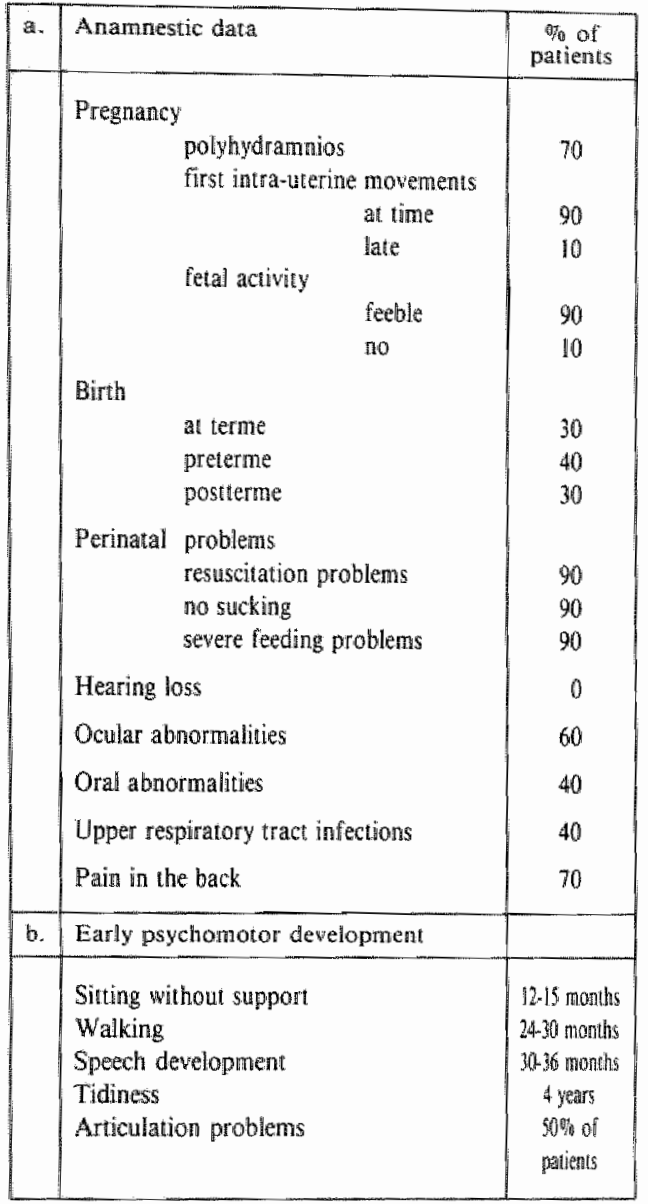

most of the children. The first words did not appear before the age of 3 years. A very characteristic finding in all patients beyond the age of 3 years was the highpitched voice and a shrill cry. At older age they spoke in short sentences and were extremely loquacious and intelligible. Articulation problems were noted in three older patients.

\section{Intellectual development}

In 9 of 12 patients, aged between 4 $10 / 12$ years and $288 / 12$ years, of the present study IQ measurements were perfor-
Figure ia: Weight ourve of patient 4 (dragnosis before the age of l'year).

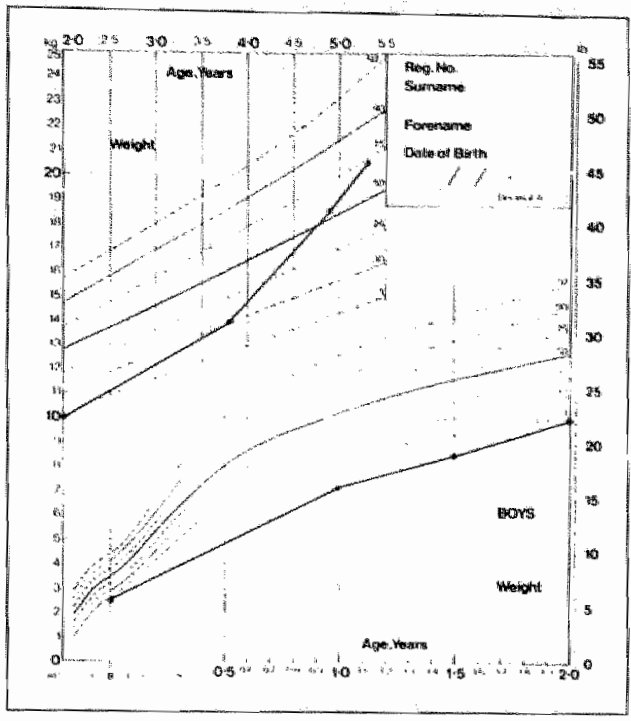

Figure 3b: Weight curve of patient 9 (disgnosis at the age of 3 years).

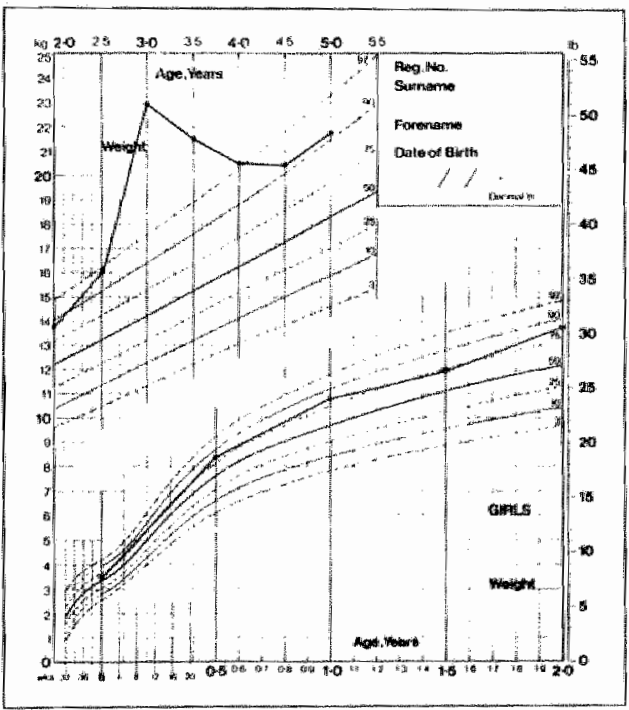

med with the Wechsler-scale (WPPSI, WISC-R, WAIS). The IQ level (total IQ) varied between 45 and 92 with a mean total IQ of 54 . Including the three youngest patients (13 months, 15 months and 
Figure $3 c$; Weight curve of patient 7 itustrating the progressive overweight problem after the age of 3 years:

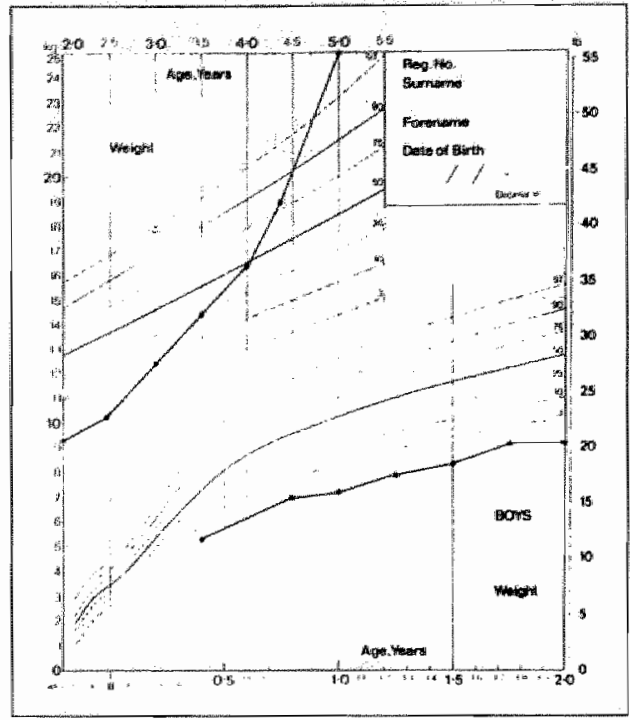

28 months at the time of evaluation), 7 PWS patients (i.e. 58\%) appeared to be mildly mentally retarded and the 5 others moderately mentally retarded (42\%). A general downward trend of intelligence was observed with age: the majority of young PWS patients functioned as mildy mentally retarded and the older patients, adolescents and adults, were moderately mentally retarded. Fig. 4 illustrates this downward trend of intelligence with age, and shows that verbal intelligence was higher than performantial intelligence in $2 / 3$ of the patients. This difference was significant in 3 of them.

\section{Behavioural \\ and psychological development}

Careful observation of the patients and interrogation of the parents and teachers showed a surprisingly similar behaviour in all of them and in additon we noted a typical and constant evolution in this behaviour with age. During infancy these toddlers were cheerfull and cordial.
We experienced them and parents described them as quier and rather passive without major behavioural problems. Between the age of 3 and 5 years this general behaviour still persisted. In addition, however, short, violent crying tantrums appeared for the first, without apparent reason but most related with withholding of food. At school age tempertantrums remained unchanged and problems regarding social intercourse arose for the first. The patients showed littlle contact with their peer group and this was apparently mostly due to their slowliness with avoidance of physical activity and the necessity of diet control. They all also had childly, immature reactions and experienced difficulties to get the feelings of others. At the age of puberty emotional and personality disorders as are strong negativism and depressive symptoms progressively appeared. Rapid alterations of behaviour and strong lability were the most striking characteristics. Although they were, in general, very friendly and

Figure 4: 1Q measurments with the Welchsler-scales in 9 patients. with PWS syndrome.

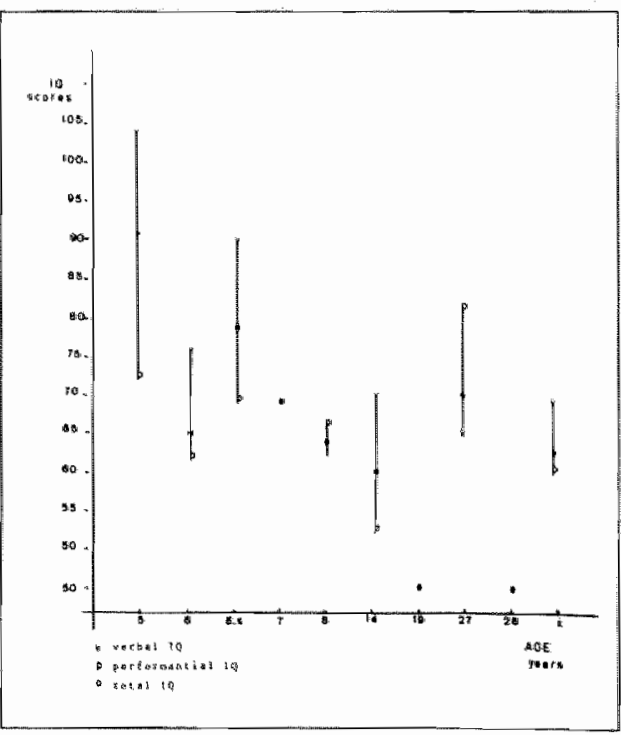


cooperative, minor changes in their environment resulted in sudden acts of inappropriate violence. Aberrant behaviour also regularly occurred in relation with the diet with stealing of food, strong stubborness and running away from home.

\section{DISCUSSION}

In the present study we had the opportunity to study the medical "psychological and behavioural aspects of the PraderWilli syndrome (PWS) after personal examination and collection of data on history and antecedents of 12 PWS patients.

In 6 of the 12 patients the diagnosis of PWS was made before the age of 1 year by one of us (JPF). Until recently, the average age of diagnosis of PWS was 7-9 years and the earlier manifestations of this syndrome were delineated in retrospect $(5,6,7)$. This is explained by the fact that an important number of cardinal symptoms of PWS are age related i.e. obesity, hyperphagia, mental retardation and hypogonadism (in the female). The diagnosis before the age of 1 year was based on the striking hypotonia with serious feeding and swallowing difficulties associated with a typical craniofacial appearance i.e. almond-shaped appearance to palpebral fissures, high forehead, narrow bitemporal diameter, hypoplasia of the malar area and high-arched palate, hypogonadism in the male patients and characteristic small hands with fusiform fingers with dorsal oedema. In 9 of the 12 patients high resolution chromosome studies could be performed and showed an interstitial deletion in the proximal part of one of the chromosomes 15 in five of them, as reported by Ledbetter et al. (3). In 4 patients a "pure» $15 q 11$ interstitial deletion was found, whereas in the other a de novo translocation between the long arm of one of the chromosomes 11 (at band 11 qter) and the long arm of a chromosome 15 (at band 15q11) was detected.
The present study hereby confirms that this type of $15 q 11$ deletion may be detectable in approximately $50 \%$ of the PW/S patients (4). Thus, the chromosomal abnormaliry although helpful in establishing the diagnosis, cannot replace the clinical signs and the request for high resolution chromosome banding should be based on clinical suspicion (10). The preand perinatal period was characterized by diminished fetal movements in $70 \%$ of the pregnancies and by polyhydramnios as a first sign of swallowing problems in PWS. This is in accordance with observations in previous studies (for review see 10). We were especially interested in the follow-up of the natural history of somatic growth, development and behaviour in the first years of life. Whereas intrauterine growth was nearly normal (mean birthweight $2760 \mathrm{gr}$ and length $49 \mathrm{~cm}$ ), there was a clear drop of the growth curve during the first two years of life; especially weight was far below the third percentile at that age. This is related with the profound hypotonia, most pronounced during the first year of life, with muscular hypotrophy and by the feeding problems due to poor sucking. In all patients the obesity problem suddenly appeared after the age of two years and was much easier and better controlled in the patients with early diagnosis.

In al』 patients hypotonia was the major symptom from birth on and this resulted in a severe delay of early psychomotor development. The gross motor milestones were not reached before the age of one year with an average for independent sitting of 12 to 15 months and for walking of 24 to 30 months. The acquisition of fine motor skills was even slower and some of them, like cutting with scissors, were never reached by half of the patients.

In the evaluation of the intellectual performances of the present patients we obtained IQ levels spread between 45 and 92 with a mean IQ of 54 . Including the youngest patients none was found in the 
group of the normal functioning nor in the group of the severely mentally retarded. $58 \%$ were mildly mentally retarded and $42 \%$ moderately mentally retarded. These results are not in complete agreement with the findings in the literature. In their study of 76 patients Holm $e t$ $a l$. (11) found $11 \%$ functioning in the normal range; $62 \%$ were mildly mentally retarded, $25 \%$ moderately mentally retarded and $7 \%$ severely retarded. The PWS parents association (UK) presented data on 27 patients aged between 30 and 40 years: $12 \%$ were at a normal intellectual level, $70 \%$ were mildly mentally retarded and $120 \%$ moderately mentally retarded. This discrepancy between these dlata and the findings in the present study may be explained by different factors as are differences in $\mathbb{Q}$ c classifications and in IQ tests and in criteria for diagnosis i.e. the erroneous classification of mentally normal, obese children in the PWS. Subtest analysis did not reveal any specific pattern of deficits. Great differences, however, were observed between the verbal and performantial IQ in two thirds of the patients. In 3 patients verbal IQ was more than 15 IQ scores higher than the performantial IQ (IQv 105 versus IQp 72; IQv 90 versus IQp 70; IQv 70 versus $I Q p$ 54, respectively). Taylor and Caldwell (12), on the other hand, compared PWS individuals with a group of obese children without the syndrome but with a similar cognitive level. They found verbal skills comparatively more depressed than non verbal skills in PWS patients with excellent performances in puzzle solving, tasks for visual perception and organisation. As previous investigators $(13,14)$ we found an evident downward trend of $\mathbb{I Q}$ levels with age. This phenomenon, however, is nonspecific for PWS and is also observed in longitudinal follow-up studies of fra( $X)$ boys (15).

As illustrated in Table IV we observed a specific behavioural profile in all patients with characteristic fluctuations with age. These children present a similar
Tabel WI: Mean subtest scores.

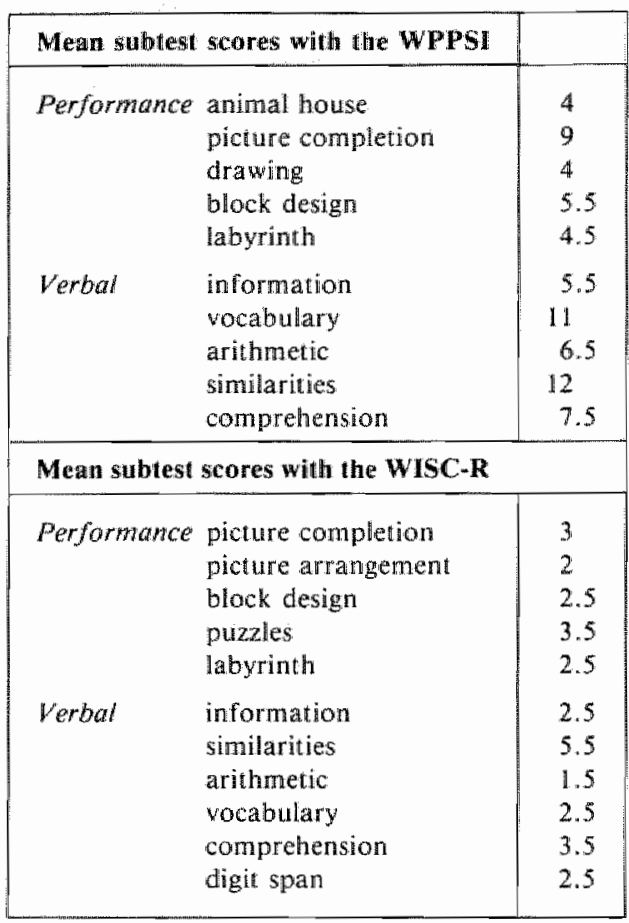

Table $W$ : Behavioural and psychological characteristics in Prader-Willi syndrome.

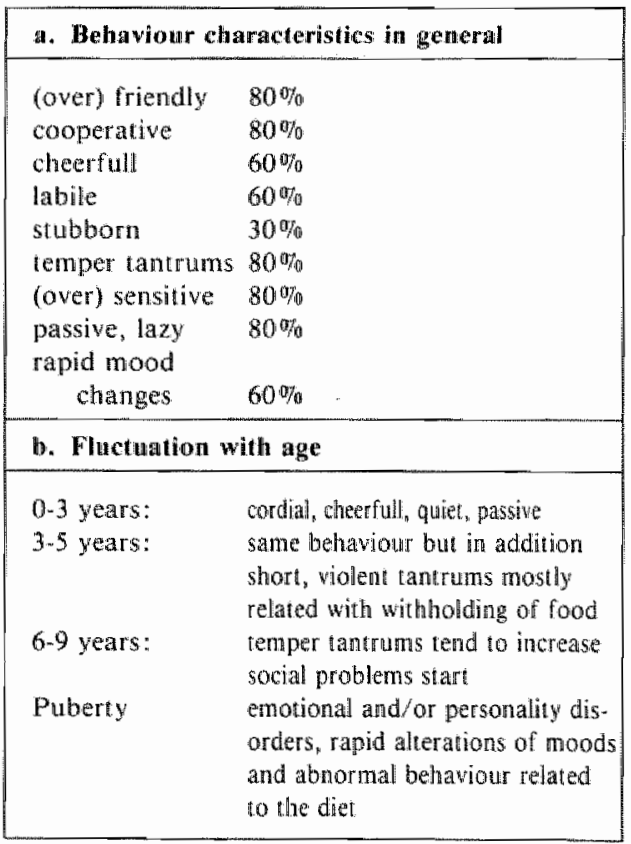


psychosocial development and behavioural disturbances. Up to the age of 3 years PWS patients behave as quiet, cordial and rather passive children. From that age on short, violent tantrums appear, mostly related with withholding of food but sometimes without any apparent reason. These rapid changes in behaviour tend to increase with age and after puberty PWS patients remain labile adolescents with periods of strong negativism and depression. This is in complete agreement with observations made in previous studies (for review see 16,17 ) and reinforces once more the hypothesis that different syndromes e.g; the $\mathrm{fra}(\mathrm{X})$ syndrome and the PWS are associated with specific disturbances in psychological and behavioural development $(15,18,19)$. A better knowledge of these behavioural characteristics may constitute an important tool in early diagnosis of these conditions. The present study also reinforces the fact that early diagnosis with adequate and intelligible information towards the parents is of outermost importance in the management of and care for children with PWS. In first instance it may help to prevent the dramatic obesity which leads towards severe physical problems and psychological burdens in PWS adolescents and adults.

\section{ACKNOWLEDGEMENTS}

The authors wish to thank the Belgian Prader-Willi Parents Association for their interest, collaboration and help.

\section{REFERENCES}

1. PRADER A. LABHART A. and WILLIH, Ein Syndrom von Adipositas, Klerimculis, Kryptorchismus und Oligophrenie nach myotonicartigem Zustand in Neugeboren-alter. Schweiz. Med. Wachenschr., 1956, 86, $1260-1261$.
2. ZELLWEGER H. and SCHNEIDER H.I. Syndrome of hypotona-thypomentia-hypogonadism-obesity (HHHO) or Prader-Willi syndrome. Am. I. Dis Child. 1969, 115. $540-598$.

3. LEDEETTER D.H., RICCARDI V.M., AIRHART S.D., STROBEL R.I., KEENAN S.B. and CRAWFORD J.D.: Deletions of chromosome 15 as a cause of the Prader-Willi syndrone. J. Pediar., 1981, 81, 286-293.

4. NIIKAWA N. and ISHIKIRIYAMA S. Climcal and cylogenetic studies of the Prader Willi syndrome: evidence of phenotype-karyonype correlation. Hum. Genet. 1985, 69, 22-27.

5. HALL B.D. and SMITH D.W.: Prader-Willi syndrome. J. Pediatr. 1972, 51, 286-293.

6. BRAY G.A., DAHMS W.T., SWERDLOF" R.S., FISER R.H., ATKINSON R.L. and CARREL R.E.: The Prader-Wili syndrome: a study of 40 patients and a review of the liter ture. Medicine, $1983,62,59-40$.

7. BUTLER M.G, MEANEY J.F, and PALMER C.G.: Clinical and cytogenetic survey of 39 individuals with Prader-Willi syndrome. Am. J. Med. Gener, 1986, 23, 793-809.

8. CREENBERG F. and LEDBETTER D.H.: Deletions of proximal $15 q$ without Prader-Willi syndrome. Am. 7 . Med. Gener, 1987, 28, 813-820.

9. PEMBREY M., FENNELL S.J., VAN DEN BERGHE J., FITCHET T M., SUMMERS D., BUTLER L., CLARKE C., GRIFFITHS M. THOMPSON E., SUPER M. and BARAIT. SER M.: The association of Angelnatin's syrdrome with deletions within 15 q $11-13 . J$. Med. Gener., 1989, 26,73.77.

10. CHITAYAT D., DAVIS EB., MCGILLLVRAY B.C., HAYDEN M.R. and HALL I.G. : Perinatal and first year follow-up of patients with Prader-Willi syndrome: nomal size of hands and feet. Clin. Genet., 1989, 35, $161-166$

11. HOLM V.A., SULZBACHER S. and PIPES P.L. cds.: Prader-Will Syndrome University Park Press, Baltinore, 1981.

12. TAYLOR R. and CALDWELL M.L.: Psychometric performances of handicopped obese individuals with and without PWS. Paper presented at the meeting of the American Association on Medical Deficiency, Dallas. Texas, 1983.

13. KRYWANIAK L.: The Prader-Willi syndrome. Mental Retardation Bulletin, 1977, 5, $30-33$. 
14. DUNN H.G, TZE W.J., AHISHARAN RM.

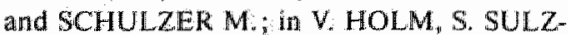
BACHER and P. P. PIPER eds., Prader-will Syndrome. University Park Presis; Baltimore, 1981.

15. BOROHGRAER M, FRYNS J.P, DIELKENS A., PYCK K and VAN DEN BERGHE H.: Fragle $(X)$ syndrome a study of the psychological profile in 23 prepubertal patients. Clin. Genet. 1987, 32, 179-186.

16. CALDWELL M.L and TAYLOR R.S. eds.: Prader-Willi Syndrome. Selected Research and Management Issues. Springer-Verlag, Berlin. 1988.
17. GREENSWAG L.R. and ALEXANDER R.C. eds.: Management of Prader-Willi Syndrome. Springer Verlag, Berlin, 1988.

18. BORGHGRAEF M., FRYNS J.P., SMEETS E., MARIEN J. and VAN DEN BERGHE H.: The $49, \times X X X Y$ syndrome. Clinical and psychological follow-up data. Clin. Genet., 1988, $33,429-434$.

19. BORGHGRAEF M., FRYNS J.P. and VAN DEN BERGHE H.: Psychological findings in three children with ring 15 chromosome. $J$. Ment. Def" Res., 1988, 32, 337-347.

Author address:

J.P. Fryns, Center for Human Genetics, UZ Gasthuisberg, Herestraat 49, B-3000 Leuven, Belgium. 
3. CLINICAL AND PSYCHOLOGICAL FINDINGS IN THREE YOUNG CHILDREN WITH FULL OR PARTIAL TRISOMY OF CHROMOSOME 8 

Tijdschr. Orthoped. Kinderpsych. 12, 9-22, 1987

\title{
CLINICAL AND PSYCHOLOGICAL FINDINGS IN THREE YOUNG CHILDREN WITH FULL OR PARTIAL TRISOMY OF CHROMOSOME 8
}

\author{
Martine Borghgraef \& J.P. Fryns
}

Centre for Human Genetics, Herestraat 49, B-3000 Leuven, Belglum

\section{SUMMARY}

In this report, we will try to delineate in a better way the clinical features and the psychological profile of children with a partial and full trisomy of chromosome 8 , by means of examination and observation of three children with this chromosomal deficiency.

On the one hand, this article illustrates the striking similarity of the fenotype of a patient with a partial trisomy of the short arm of chromosome 8 , with the clinical features of patients with a full trisomy (in mosaic).

On the other hand, during an indepth analysis and comparison of the data concerning the mental level and the behaviour of these three children, we can make some important conclusions as to the intelligence profile, the development of speech and language and a few common behavioural characteristics.

Apart from the classical, now well delineated autosomal and sex chromosomal deficiencies such as Down syndrome, Turner syndrome, and Klinefelter syndrome, more than 250 different chromosomal deficiencles were described during the last years, all of them characterized by typical clinical features (de Grouchy \& Turleau, 1982). The individualisation of these chromosomal syndromes is especially due to the introduction of the different banding techniques in clinical cytogenetics.

Partial and full trisomy of chromosome 8 is an example of this. In this paper, we will try to delineate the clinical features and psychological profile of these chromsomal deficlencles in a better way, by examination of three children with this chromosomal deficiency. 


\section{RESEARCH DATA}

\section{Patient 1}

D.W.J., a boy, was referred at the age of 1 . He is the first child of young, unrelated parents. Pregnancy and delivery, at 37 weeks, were normal. Birth weight, length, and head circumference were respectively $2900 \mathrm{~g}, 49.5 \mathrm{~cm}$ and $34.5 \mathrm{~cm}$. There were no specific problems in the immediate postnatal period, but from the second week on, feeding problems like slow drinking, problems with sucking and swallowing became obvious. Because of severe retardation of the psycho-motoric development and the presence of a number of dysmorphic signs at clinical examination, a chromosomal examination was asked for at the age of ten months.

\section{Cytogenetical findings}

Chromosomal analysis was done by means of Giemsa banding technique in 85 cells of a lymfocyte-culture. In all cells, we found additional material in the long arm of one of the chromosomes 8 . This extra material was identified as a duplication of a part (8p21.1->p11) of the short arm of chromosome 8 (Figure $1 \mathrm{a}$ and $\mathrm{b}$ ).

Chromosomal examination of both parents is normal. As a consequence, the partial trisomy 8 with the child originated de novo.

\section{Clinical findings at the age of 1 year (figure 2)}

On clinical examination, most striking was the morphology of the round face, with curly hair, coarse features, big forehead, broad and flat nasal bridge with anteverted nares, alternating strabism, big mouth with a fine upper lip and eversion of the lower lip, small lower jaw, and low-set ears. The neck was short and the thorax thin and long with small, widely spaced nipples. There was striking neurological abnormalities with spastic diplegy of the lower limbs, which contrasted with an axial hypotony, causing serlous deviations of the spine. The somatic development, however, was normal, with a normal increase in length $(78 \mathrm{~cm})$ and a normal weight-curve $(10 \mathrm{~kg})$.

Psychodiagnostic evaluation data at the age of one year

These data are based on examination and observations of the child with the parents, with the BOS 2-30 (Van der Meulen \& Smrkovsky, 1983) in its natural environment. This little boy showed a serious developmental 
retardation. At the calendar age of 13 months, $\mathrm{J}$. functioned on a mental level of 7 months, and on a motor age of 5 to 6 months. Next to the mental retardation, the strong motor delay inhibited a spontaneous exploration of the environment and material.

Perceptual-cognitive development - The toys were briefly felt and manipulated. There was little purposeful manipulation of toys and no attempts to imitate. J. was still in the phase of oral exploration. His attention could only be caught for a short period, and even this was very difficult. As to the sensorial perception, the auditive and tactile reactions were more strongly developped than the visual ones. The coordination of eye and hand was very weak, and there was a limited eye-to-eye contact.

Language development - The understanding of language was hardly developed. There wasn't any expressive babbling yet ${ }_{\text {" }}$ and vocalisations were poorly differentiated.

Behaviour and social contact - Social smile and vocalisation as a reaction to spoken language were present. There was no fear of strangers but he did recognize relatives. The eye-to-eye contact was limited although evasive.

Motoric development - J. didn't crawl yet. When he was sitting down, there was little equilibrium or reaction of support. Lying on his belly he showed little tendency to lift his head and when we put him on his feet, there was no reaction of support. The handfunction, on the contrary, had progressed more quickly: he caught very reasonably and manipulated still a lot from pronation.

\section{Patient 2}

Z.D., a boy, was the first child of young, healthy parents of Italian origin. Pregnancy and delivery were normal, and the postnatal growth-curve was satisfactory. At the age of six months a chromosomal analysis was performed because of the striking facies and the presence of deformations of the thoracic spine.

Cytogenetic examination

Chromosomal analysis, performed with Giemsa-banding in 99 cells of 2 lymfocyte-cultures showed a $46, X Y / 47, X Y,+8$ mosaicism. In 81 cells we found a normal male karyotype, but in 18 cells we found each time 47 
chromosomes with an additional chromosome 8. There is a mosalcism in which in about $20 \%$ of the cells an additional full chromosome 8 is shown (Figure 3).

Clinical data at the age of $4 ; 3$ (Figure 4)

Normally proportioned boy with a normal length- and woight-curve. (weight: 19kg, length: $112 \mathrm{~cm}$, head circumference: $53.2 \mathrm{~cm})$. There was Indeed a striking facial dysmorphy with curly halr, a big forehead, square face, flat nasal bridge, small ears and a typical mouth with small upper lip and hanging lower lip. Further physical examination was Inconspiclous except from very deep grooves in the sole of the foot.

Psycho-diagnostic evaluation data at the age of 4;6

These data are based on tests and observation of this little boy with the WPPSI-Intelligence test (Wechsler, 1981) in his natural environment. D. showed a slight developmental retardation, with especially problems as to language and speech. The evolution was favourable and positive. The totall intelligence quotient could be situated at 99 (verbal IQ 92, performance IQ 110).

Perceptual-cognitive development. - There was a strong discrepancy between the verbal Intelligence and the practical insight. The profile of the practical skills-scale was rather harmonical. On the verbal scale, the most strlking was a well developped capability of abstraction, few understanding of numbers and a short audithe memory. D.'s way of doing things was slow, but rational.

Language development. - D. used most of all two-word sentences or short simple multiple word sentences. He had a number of speech deficiencies: letters and/or parts of words were left out or transposed.

Behaviour and soclal contact. - D. was an introvert and strongly insecure child: he reacted in a shy and withdrawn way and wasn't very talkative in the presence of strangers. D. avoided eye-to-eye contact. On the other hand, at home he could be very demanding and egocentric.

Motoric development. - The gross motor movements were fluent and controlled. D. was slow and insecure in his fine motor movements. 


\section{Patient 3}

V.A., a girl, was the first born out of a family of two children. Her brother, who is five years younger, is normal. Famillal anamnesis is fully negative. Pregancy and delivery were normal. The birth weight was $3.100 \mathrm{~kg}$. There were no striking problems in the first years, but the parents started to worry from 18 months on, because of the lack of speech development. Mainly for this reason, a chromosomal analysis was asked for at the age of 7 years.

\section{Cytogenetic findings}

A total of 28 cells, from 2 lymfocyte cultures, were analyzed. Here too we found a trisomy 8 mosalcism with karyotype: $46, X X / 47, X X_{n}+8$. In 22 of the 28 examined cells $(=80 \%)$ we found the additional chromosome 8 (Figure 3).

\section{Clinical data}

A first examination at the age of 8 years showed normal growth parameters (weight: $24.5 \mathrm{~kg}$; length: $130 \mathrm{~cm}$; head circumference: $54.5 \mathrm{~cm}$ ). With this girl as well, the head was remarkably large with bossing of the forehead, slight ptosis of the eye-lids, coarse features, long upper lip and small chin. The neck was short with low hair Implantation, and she had a small thoracic cage. The limbs were graciously built and the lines of handpalm and footsole were distinctively more deeply grooved than normal. A second examination at the age of 15 years showed a normal development of puberty and a normal growth (weight $54 \mathrm{~kg}$, llength $168 \mathrm{~cm}$, head circumference $56 \mathrm{~cm}$ ). The features of dysmorphy were as strilking as at younger age.

Psychodiagnostic evaluation data at the age of 15 years

These data are based on tests and observations with the WISC-R intelligence test (Wechsler, 1981). This girl showed a slight developmental retardation and could be situated in the group of children with slight mental retardation. She needed special education and accompanied work. Her total intelligence quotient was 78 (verbal IQ 72 , performance IQ 87).

Perceptual-cognitive development. - Results on performance-oriented tasks were significantly better than on verbal-oriented tasks. On the proflle of 
practical Intelligence, a strong analytic-synthetic capability was very striking, as well as a good spatial perception and a strong visual and auditive memory. On the verbal scale she presented a well developped capability of abstraction, but also a week social intelligence and verbal understanding. A. was slow but rational in her work.

Language development: - The gir used multiple word sentences, and had an extensive vocabulary. There were a number of speech problems, with serious hyperrhinophony.

Behaviour and social contact. - The girl reacted in a very shy and withdrawn way. She wasn't very talkative and had only little eye-to-eye contact. She had a rather introvert character, and a lack of self-confidence. She had a good attitude toward her tasks and performed her tasks diligently and dutifully.

Matoric development. - She gave a good general impression. Fine finger movements were coordinated and gross motor movement was fluent. A. was rather slow in her movements, and had a tense posture.

\section{DISCUSSION}

After the development of the cytogenetic techniques, trisomy 8 was described in more than 150 patients, and in most cases, this trisomy 8 was found in mosaic with a normal cell-line (de Grouchy \& Turleau, 1982). Up to now, no prevalence data are known.

This so-called trisomy 8-mosaicism goes hand in hand with a clinical recognizable syndrome: indeed, at physical examination, these patients show a whole number of identical physical features and/or inborn malformations. Especially the cranofacial stigmata are always striking: curly hair, big forehead, triangular face, flat nasal bridge with upturned nose, thin upper lip and hanging lower lip. Furthermore, the neck is mostly short, the thorax wide with widely spaced nipples. There are no striking limbdefects, but a very typical diagnostic feature are the deep grooves in the palms of the hand and/or the soles of the feet. The overall physical development is furthermore normal, and neurologic examination shows no gross motoric deficiencies. The life expectancy of these patients is favourable, as deficiencies of the inner organs are seldom. Devlations of the skeleton, such as vertebral deviations, are more frequent, and often result in spine deviations with hyperkyphosis, hyperlordosis and/or scoliosis.

Nowadays, patients are known with partial trisomy for different segments of the short and long arm of chromosome 8 . The best documented are these 
with partial trisomy for a specific segment in the short arm of chromosme 8 (the so-called 8p21.1->8p22 partial trisomy), as can be found with the first patient described in this paper. Up to now, 7 patients with this partial trisomy of the short arm of chromosome 8 are described (Taylor e.a., 1977; Jensen e.a., 1982; Hongell e.a., 1978; Fryns e.a.. 1985). It turns out from this literature how striking the fenotype of this partial trisomy corresponds to the clinical features found with trisomy 8-mosaicism. The first patient from this article is an illustration of this, and also with this young child, we find the same facial features as with patient 2 and patient 3 with mosaic 8 trisomy (table 1). A striking difference are the neurological deficiencies with the partial 8-trisomy: from young age on, as with patient 1 , an apparently increasing spasticity of the limbs is obvious, contrasting with an apparent axial hypotony. In grown-up patients, this serious neurologic problem has resulted in severe orthopedic deformities, such as luxation of the hip and strong deviations of the spine.

It is commonly known that autosomal chromosome deficiencies go hand in hand with mental retardation, but little is known about the degree and the kind of the mental retardation and behavioural characteristics of patients with the same chromosomal deficiency. In this study, we have tried to describe the psychological profile and the behavioural features of three children with partial and full trisomy of chromosome 8.

When performing an indepth analysis and mutual comparison of the data concerning the mental level of functioning and the behaviour of our three patients, we can draw some important conclusions.

First of all, we found an important discrepancy concerning level of intelligence (table 1). The youngest patient with mosaic trisomy 8 was funtioning at borderline level, the other patient shows a mild mental retardation. The child with partial trisomy 8 shows a serious psychomotoric retardation and can be situated in the group of moderate mentally handicapped children. In the literature, we find similar findings (table 2a and $2 b)$. The patients with partial trisomy 8 are moderate to severely mentally retarded (Taylor e.a., 1977; Hongell e.a., 1978; Jensen e.a., 1982; Fryns e.a., 1985). The majority of patients with mosaic trisomy 8 function at the level of borderline up to normal intelligence (Schinzel, 1974 \& 1981;

Sperber e.a., 1978; Theilgaard e.a., 1977; Chandley e.a., 1980; Riccardi e.a., 1970). The others are spread over the levels of slight mental retardation (Riccardi e.a., 1970; Cassidi e.a., 1975) and moderate mental retardation (Rethoré e.a., 1977).

The second conclusion concerns comparable intelligence profile in children with the mosaic trisomy 8 . The discrepancy between results on performantial tasks on the one hand and verbal tasks on the other hand is 
striking. The two children that were examined by us have a remarkably higher performance IQ than a verbal IO. Schinzel $(1974,1981)$ found the same with his patient at two different ages (11 years - 18 years). In the other cases of the Itterature he refers to (Sperber, 1975; Thellgaard, 1977; Chandley, 1980; Riccardi $\theta . a_{.}, 1970$ ) the discrepancy is smaller and sometimes quite the opposite, but the subjects are generally older. From the profile of the subtest results we can conclude that both children perform poorly in tasks concerning the capability of understanding and reasoning and the visuomotoric speed. Better results are obtained for tasks concerning the synthetic-analytic capability and memory. The data we find in literature are rather heterogenuous. Theillgaard (1977) and Cassidy (1975) pointed in their patients to a remarkable score for memory "auditive attention and visuomotoric skills and specific problems in the domain of gestalt-perception and structures. Both patlents of Riccardl (1970) with mosalc trisomy 8 performed poorly on tasks concerning reasoning and logical thinking, but had very good abilitles for memory and imitation. On evaluation of the development of speech and language, we find a clear retardation and restraints on the verbal level in both children with mosaic trisomy 8, they both followed an intensive logopedic therapy. Cassidy (1975) and Riccardl (1970) described also a retarded language development and serilous speech problems in three boys.

The last conclusion deals with a similarity in behavioural chracteristics in both children with mosaic trlsomy 8 . They reacted in a shy way and are timid and somewhat withdrawn. There was a limited eye-to-eye contact. They are rather introvert personalities, who lack selfconfidence. These two chlldren worked in a slow pace and took their time before acting. Attention and concentration were good. They had a good attitude and tension towards tasks. The second patient seemed to show a more difficult behaviour in a home-situation. Schinzel $(1974 ; 1981)$, Cassidy (1975), and Riccardl (1970) observed the same behavioural characteristics and noted among others two patients with frequent occurences of temperattacks. The present study confirms our experience that specific chromosomal deficiencles are coupled with a characterlstic psychological profile, as already indicated for fraglle $(X)$ syndrome. The group of patients we examined up to now is too small to draw definitive conclusions, and don't give any indication yet as to the changes in behaviour profile related to age.

\section{REFERENCES}

Cassidy S.B., McGee B.J., van Eys J., Nance W.E., Engel E. Trisomy 8 syndrome. Pedlatrics, 1975 (56), 826-831.

Chandley A.C., Hargreave T.B., Fletcher J.M., Soos M., Axworthy D \& Price 
W.H. Trisomy 8. report of a mosaic human male with near-normal phenotype and normal IQ, ascertained through infertility. Hum. Genet., $1980(55), 31-38$.

de Grouchy J. \& Turleay C. Atlas des Maladies Chromosomiques. 2de ed., Paris, Expansion Scientifique Française, 1982.

Fryns J.P., Kleczkowska A., Dereymaeker A.M., Hoefnagels M., Heremans

G., Marien J., Van den Berghe H. Partial $8 p$ trisomy due to interstitial duplication: karyotype: $46, X X$, inv dup(8)(p21.1-p22). Clin. Genet., 1985 (28), 546-549.

Hongell K., Knuutlle $S_{\text {; }}$ Westermark $T$. Two cases of an abnormal short arm of chromosome $8(8 p+)$ associated with mental retardation. Clin. Genet. 1978 (13), 237-240.

Jensen P.K.A., Junien C., Despolsse S., Bernsen A., Thelle R., Friedrich U. $\&$ de la Chapelle A. Inverted tandem duplication of the short arm of chromosome 8: a non-random de novo structural aberration in man. Localization of the gene for glutathione reductase in subband $8 \mathrm{p} 21.1$ Ann. Génét., 1982 (25), 207-211.

Rethoré, M.O. Aurias A., Couturier J., Dutrillaux B., Prieur M., Lejeune J.

Chromosome 8: trisomie complète et trisomle segmentaires. Ann. Génét., 1977 (20), 5-11.

Riccardi V.M., Atkins L. \& Holmes L.B. Absent pateliae, mild mental retardation, skeletal and genitourinary anomalies, and C-group autosomal mosailism. J. Pedlat., 1970 (77), 664-672.

Schinzel, A. Particular behavioral symptomatology in patients with rarer autosomal chromosome aberrations. In: W. Schmid \& J. Nielsen (Eds.), Human Behavior and Genetics, Elsevier/North-Holland Biomedical Press, 1981, p. 195-210.

Shirissen, J. \& Vander Steene G. Wechsler Preschool and Primary Scale of Intelligence. Handleiding bil de Vaamse aanpassing. Lisse, Swets en Zeitlinger, 1981, $138 \mathrm{pp}$.

Sperber M.A. Schizophrenla and organic brain syndrome with trisomy 8 (Group C trisomy $8(47, X X, 8+)$. Blol. Psych., 1975 (10), 27-43.

Taylor, K.M., Francek, U., Brown, M.G., George, D.L. \& Kauthold M. Inverted tandem ("mirror") duplications in human chromosomes: Inv dup $8 p, 4 q$, 22q. Am. J. Med. Genet., 1977 (1), 3-19.

Theilgaard A., Lundsteen C., Parving H.H. \& Phillip J. Trisomy 8 syndrome. A psychological and somatic study of a mentally non-retarded male with $46, X Y / 47, X Y,+8$ chromosome constitution. Clin. Genet., 1977 (12), $227-$ 232.

Van der Meulen B.F. \& Smirkovsky M. BOS 2-30, Bayley

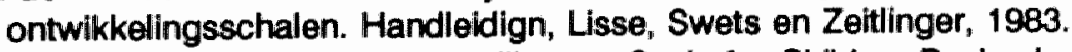
Van Haasen P. et al. Wechsler Intelligence Scale for Children Revised. 
Nederlandstalige uitgave. Handleiding voor instructies en scoring. Lisse, Swets en Zeitlinger, 1985, 5 pp.

Withworth J., Ruth, Sutton et al. WISC-R compilation. What to do now you know the score. Novato, Cal., Acad. ther, Publ, 1978, 240 pp.

Table 1. Cytogenetics, clinical and psychologicall findings in the patients with partial trisomy 8 and mosaic trisomy 8 tested by us.

\begin{tabular}{|c|c|c|c|c|}
\hline $\begin{array}{l}\text { Pattient } \\
N^{\circ}\end{array}$ & Sex/age & Cytogenetic findings & Clinical findings & $\begin{array}{l}\text { Psychological } \\
\text { find ings }\end{array}$ \\
\hline 1 & $\$ / 1$ & $\begin{array}{l}46, x \gamma, \text { inw dup }(8) \\
(p 21,1->\text { p22) de nowo }\end{array}$ & $\begin{array}{l}\text { Face: curly hair } \\
\text { round face } \\
\text { big forehead } \\
\text { broad, flat } \\
\text { nasal bridge } \\
\text { with upturned } \\
\text { nose } \\
\text { big mouth with } \\
\text { fine upper lip } \\
\text { and eversion of } \\
\text { the lower lip } \\
\text { small lower jaw } \\
\text { Short neck } \\
\text { Thin and long tharax }\end{array}$ & $\begin{array}{l}\text { M.A.: } 7 \text { months } \\
\text { IQ } \pm 53\end{array}$ \\
\hline 2 & $8 / 4 ; 6$ & $\begin{array}{l}46, X Y / 47, X Y,+8 \\
\text { in } 18 / 27 \text { examined } \\
\text { cells }(20 \%)\end{array}$ & $\begin{array}{l}\text { Face: curly hair } \\
\text { big forehead } \\
\text { flat nasal } \\
\text { bridge } \\
\text { Deep grooves in solle } \\
\text { of feet }\end{array}$ & $\begin{array}{ll}\text { Tot. IQ } 99 \\
\text { Verb. IQ } 92 \\
\text { Perf. I0 } 110\end{array}$ \\
\hline 3 & $8 / 15$ & $\begin{array}{l}46, x \times / 47, \quad x x_{4}+8 \\
\text { in } 22 / 28 \text { examined } \\
\text { cells }(80 \%)\end{array}$ & $\begin{array}{l}\text { Face: big head with } \\
\text { frontal boss ing } \\
\text { slight ptosis } \\
\text { long upper lip } \\
\text { Short neck } \\
\text { Small thoracic cage } \\
\text { Deep grooves in sole } \\
\text { of feet } \\
\text { Normal development of } \\
\text { puberty }\end{array}$ & $\begin{array}{l}\text { Tot. IQ } 78 \\
\text { Verb. IQ } 72 \\
\text { Perf. IQ } 87\end{array}$ \\
\hline
\end{tabular}


Table 2a. Cytogenetics in the patients with partial trisomy 8

\begin{tabular}{|c|c|c|c|}
\hline Patient & Age at findings & Cytogenetic examination & $\begin{array}{l}\text { Level of } \\
\text { development }\end{array}$ \\
\hline $\begin{array}{l}\text { Fryns et al. } \\
(1985) \text { P. } 1\end{array}$ & 24 years & $\begin{array}{l}\left.46, x x_{1} \text { inv dup( } 8\right) \\
(p 211.1 \rightarrow p 22) \text { de novo }\end{array}$ & $\begin{array}{l}\text { severe menta } \\
\text { retardation }\end{array}$ \\
\hline $\begin{array}{l}\text { Honge } 11 \text { et al. } \\
(1978)\end{array}$ & $25 y$ & $\begin{array}{l}\text { 46, XY, dup }(8) \\
(p 21 * 023) \text { origin? }\end{array}$ & $\begin{array}{l}\text { severe mental } \\
\text { retardation }\end{array}$ \\
\hline $\begin{array}{l}\text { Jensen et a ... } \\
\begin{array}{l}\text { (1982) P. } 1 \\
\text { P. } 2\end{array}\end{array}$ & $\begin{array}{l}18 \text { mo } \\
18 \text { years }\end{array}$ & $\begin{array}{l}46, x x, \text { jnv dup( }(8) \\
(p 21.2 \rightarrow p 23.1) \text { de novo } \\
46, x \times, \text { inv dup }(8) \\
(p 21 \rightarrow p 23.3) \text { de novo }\end{array}$ & $\begin{array}{l}\text { M.A. } 8 \text { months } \\
10 \pm 44 \\
\text { severe mental } \\
\text { retardation }\end{array}$ \\
\hline $\begin{array}{l}\text { Taylor et al., } \\
(1977)\end{array}$ & $2 y$ & $\begin{array}{l}46, x Y \text {, inv dup(B) } \\
(p 21 \rightarrow p 23) \text { de novo }\end{array}$ & $\begin{array}{l}\text { M.A. } 19 \text { months } \\
1 Q \pm 42\end{array}$ \\
\hline
\end{tabular}

Table 2b. Summary of the cytogenetic findings and intelligence data of patients with a trisomy 8 in masaic.

\begin{tabular}{|c|c|c|c|c|}
\hline \multirow{2}{*}{$\begin{array}{l}\text { Patient } \\
\text { Chand ley (1980) }\end{array}$} & \multirow{2}{*}{$\begin{array}{l}\text { Age at moment } \\
\text { of examination }\end{array}$} & \multirow{2}{*}{$\begin{array}{l}\text { Cytogenetic findings } \\
46, X Y / 47, X Y,{ }^{\circ} 8 \\
\text { in } 62 \% \text { of the cells }\end{array}$} & \multicolumn{2}{|c|}{$\begin{array}{l}\text { Jevel of } \\
\text { Intelligence }\end{array}$} \\
\hline & & & $\begin{array}{l}\text { IQ } 102 P \\
V 105\end{array}$ & 997 \\
\hline \multicolumn{5}{|c|}{$\begin{array}{l}\text { Rethoré \& Aurias } \\
\text { (1977) }\end{array}$} \\
\hline 1 & 11 years & $\begin{array}{l}46, X Y / 47, X Y,+8 \\
\text { in } 65 \% \text { of the cells }\end{array}$ & IQ 51 & \\
\hline 2 & 22 years & $\begin{array}{l}46, X Y / 47, X Y,+8 \\
\text { in } 52 \% \text { of the cells }\end{array}$ & 1054 & \\
\hline 3 & 14 years & $\begin{array}{l}46, X Y / 47, X Y,+8 \\
\text { in } 60 \% \text { of the cell } 1 \mathrm{~s}\end{array}$ & 1060 & \\
\hline Sperber (1975) & 33 years & n.d. $(x x)$ & I0 96 & $\begin{array}{ll}p & 78 \\
V & 109\end{array}$ \\
\hline $\begin{array}{l}\text { Schinzel } \\
(1981)\end{array}$ & 18 years & n.. d. & 1086 & $\begin{array}{l}P 95 \\
\vee 78\end{array}$ \\
\hline $\begin{array}{l}\text { same patient } \\
\text { in } 1974\end{array}$ & 11 years & n.d. & IO 80 & $\begin{array}{l}p 92 \\
\vee 75\end{array}$ \\
\hline $\begin{array}{l}\text { Thei Igaard } \\
(1977)\end{array}$ & 21 years & $\begin{array}{l}46, X Y / 47, X Y,+8 \\
\text { in } 70 \% \text { of the cells }\end{array}$ & IQ 95 & $\begin{array}{l}P 85 \\
y 103\end{array}$ \\
\hline
\end{tabular}




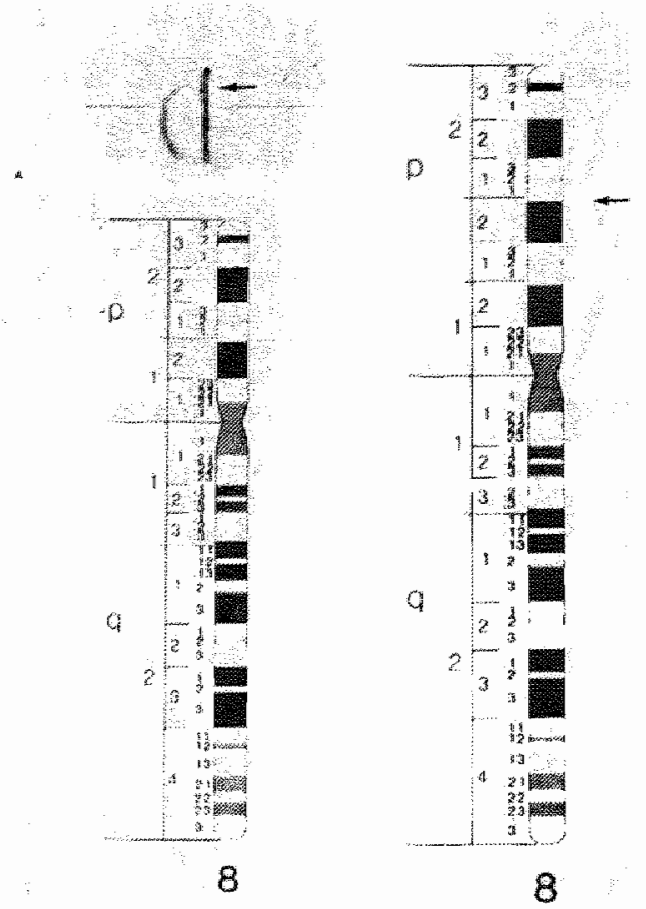

Fig. 1 a. One pair of chromosomes 8 with a duplicated part (indicated by an arrow) - b. normal chromosome - c. chromosome 8 with duplicate of a part (Bp21.1+p11) of the short arm (indicated by an arrow).

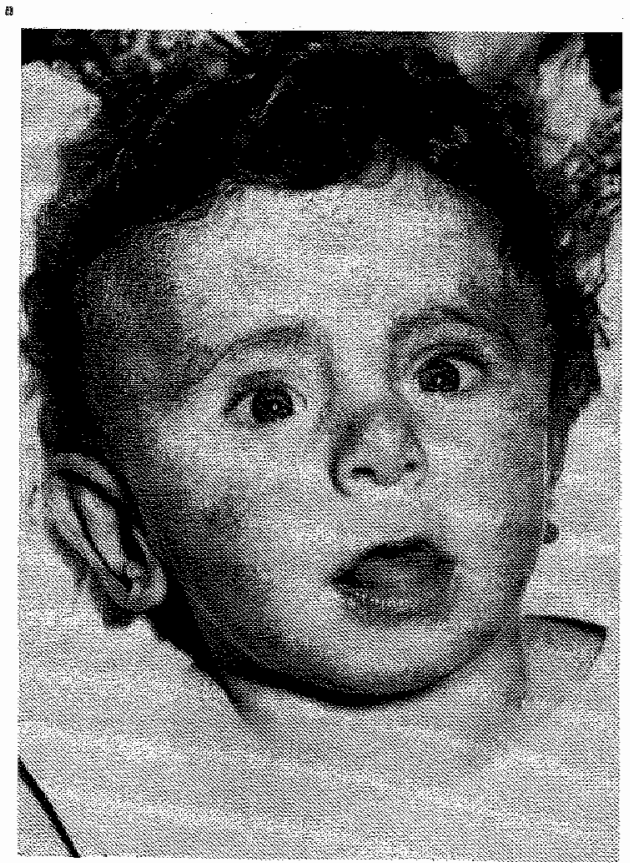

Fig. 2. Patient 1.. 


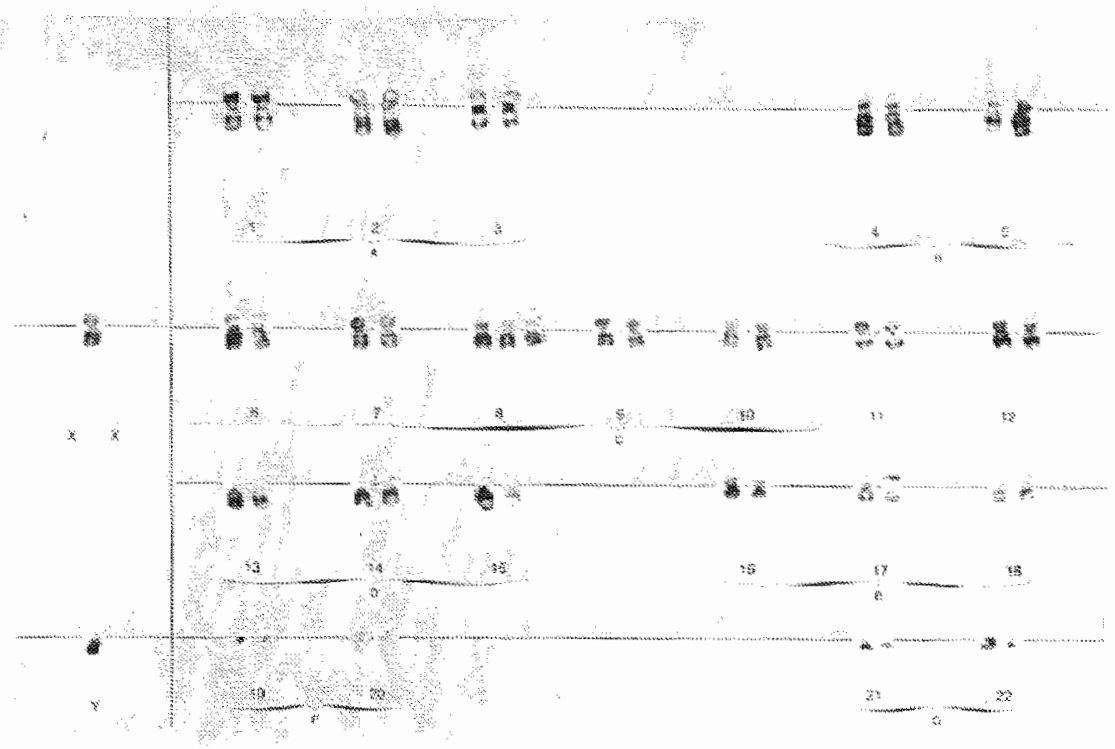

Fig. 3. Chromosomes-chart with 47 chromosomes, among which an additional chromosome 8.

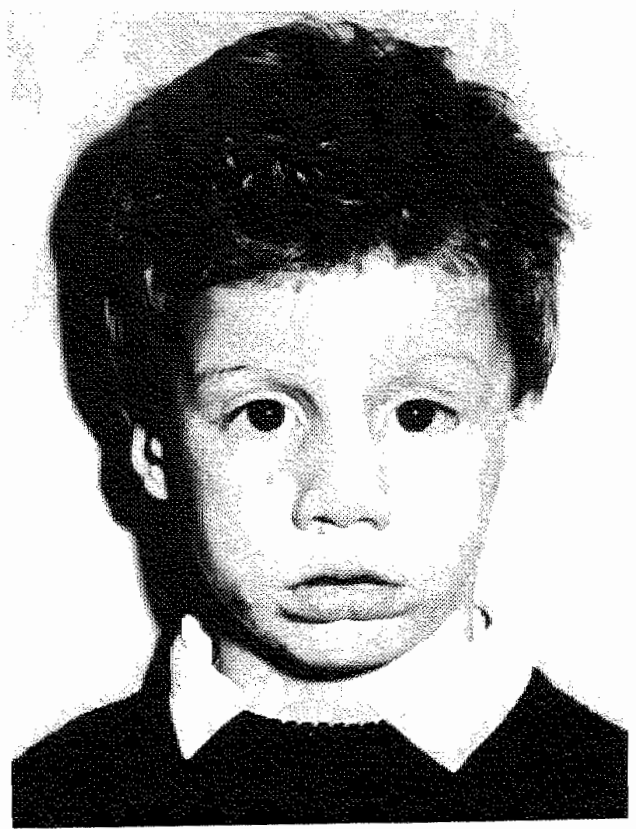

Fig. 4. Pationt 2. 
4. PSYCHOLOGICAL FINDINGS IN THREE CHILDREN WITH RING 15 CHROMOSOME 


\title{
CASE REPORT
}

\section{Psychological findings in three children with ring 15 chromosome}

\author{
M. BORGHGRAEF, J. P. FRYNS AND H. VAN DEN BERGHE \\ Centre for Human Genetics, University of Leuven, Lewen, Belgium
}

\begin{abstract}
In this paper, the authors present a description of the clinical and psychological data of three girls with ring chromosome 15 . These children were carefully obserwed and tested on their mental level and school skills, and the results are compared with the findings in the literature. In general, patients with ring 15 present a mild to moderate mental retardation, with some language difficulties at early age. Observation of behaviour and social skills, present these patients as cordial, willing and with good social integration, despite their severe growth failure.
\end{abstract}

\section{IN TRODUCTION}

Autosomal chromosomal abnormalities are diagnosed in patients with multiple congenital anomaly-mental retardation syndromes and, in the majority of them, mental retardation is severe to profound. One of the few exceptions on this general rule is ring chromosome 15 syndrome. Since the introduction of the different banding techniques in human cytogenetics, at least 26 patients with this ring chromosome abnormality were reported (Jacobsen, 1966; Emberger et al., 1971; Forabosco et al., 1972; Stoll et al., 1975; Rumenic et al., 1976; Ferrante et al., 1977; Pfeiffer et al., 1977; Fujita \& Matsumoto, 1978; Scheibenreiter \& Frisch, 1978; Schmid et al., 1978; Wisniewski et al., 1979; Gardner et al., 1980; Ledbetter et al., 1980; Kousseff, 1980; Meinecke \& Koske-Westphalt, 1980; Benadiba et al., 1981; Yunis et al., 1981; Kiss \& Osztovics, 1982; Moreau \& Teyssier, 1982; Otto et al., 1984; Fryns et al., 1979, 1981, 1986) (Table 1).

A ring chromosome formation is caused by breakage in each of the two chromosomal arms followed by fusion of the broken ends. This mechanism presumes the loss of chromosomal material, particularly of the terminal segments (Fig. 1).

The clinical syndrome in ring chromosome 15 patients is relatively constant and includes severe pre- and postnatal growth retardation, with absence, however, of gross dysmorphic symptoms. Moderate mental retardation has been reported in most of the patients. Up to now, few data on the cognitive development and behaviour characteristics of these patients were published. The purpose of the present study was to delineate more accurately the developmental and behavioural profile in ring chromosome 15 patients. The authors had the occasion to observe and evaluate three 


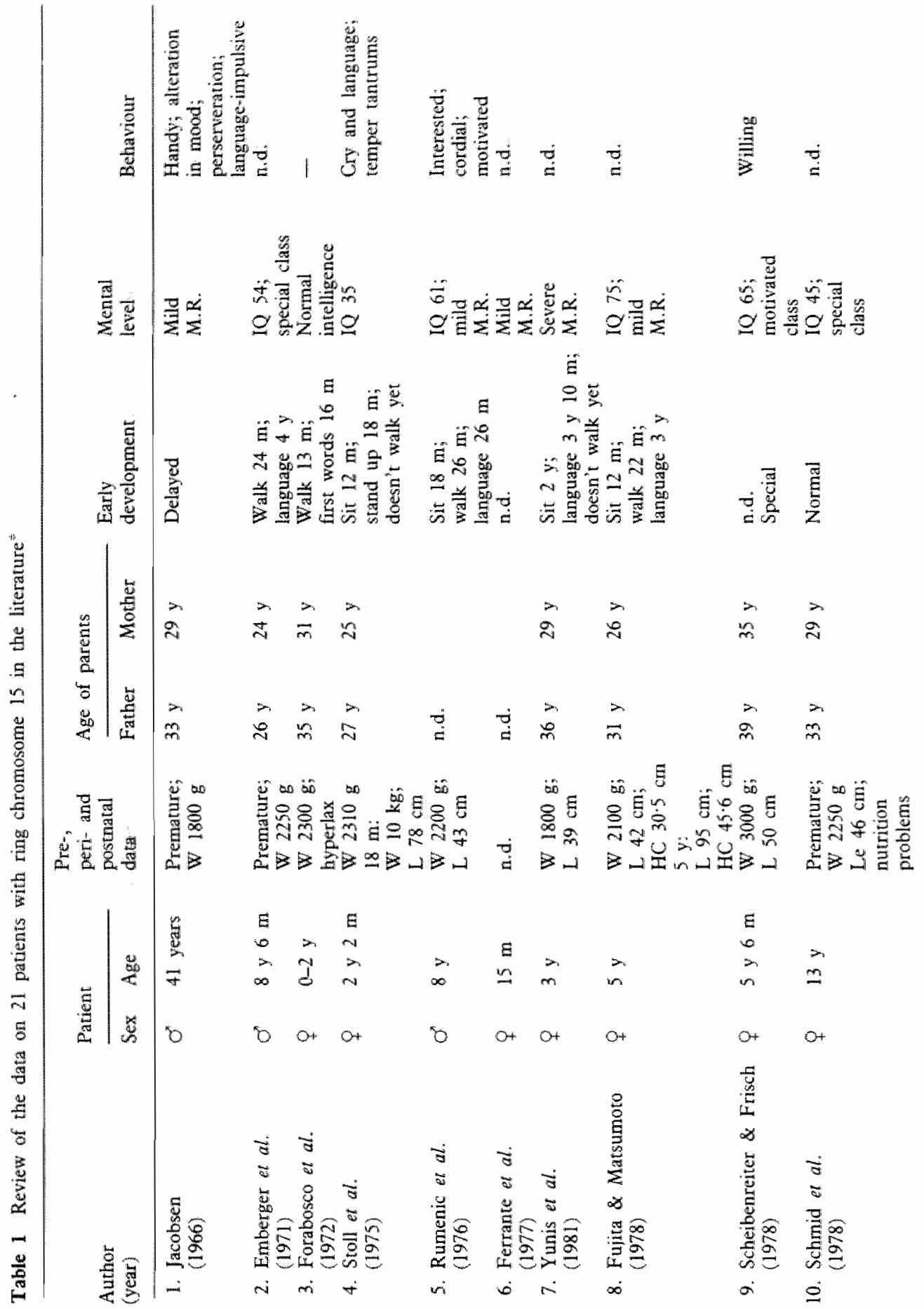


Three children with ring 15 chromosome 171

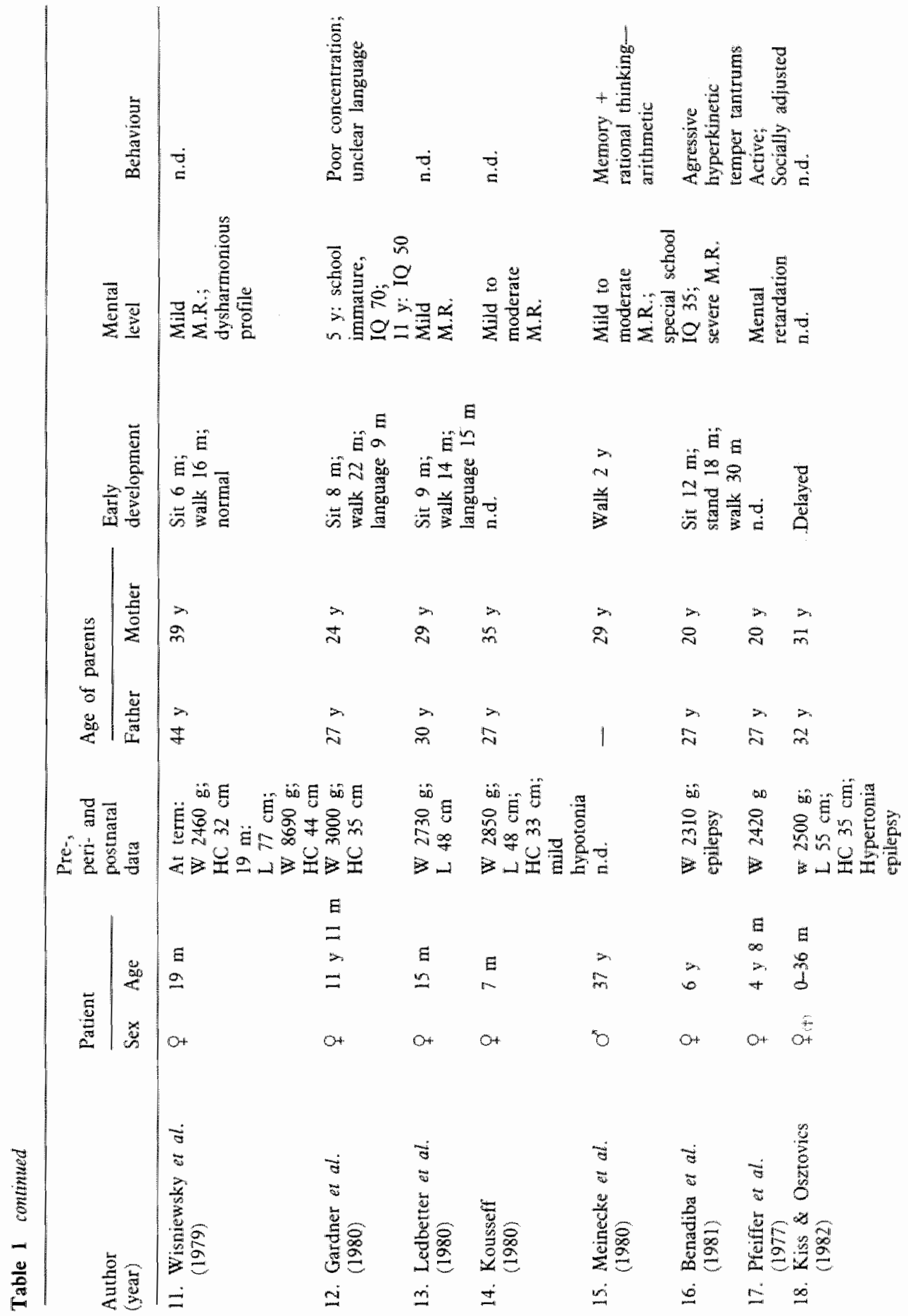


172 M. Borghgraef, F. P. Fryns and H. Van Den Berghe

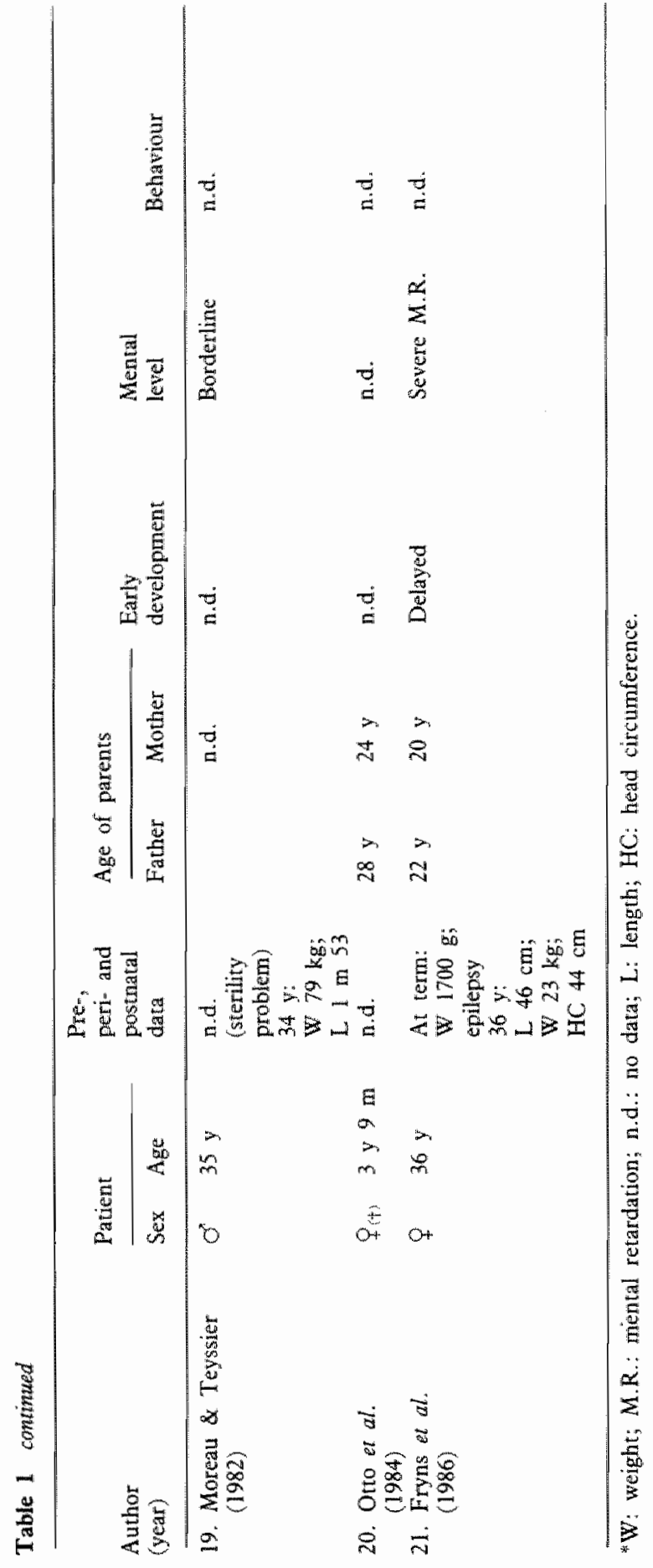




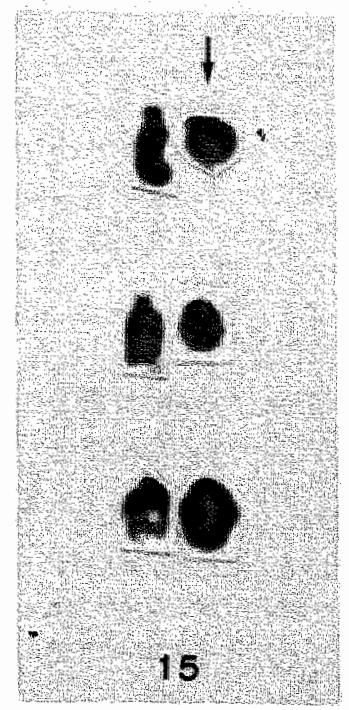

Fig. 1 Three pairs of chromosomes 15 with ring chromosome indicated by an arrow.

girls with this ring chromosomal syndrome, and tested their mental level, school skills and behaviour qualities (Table 2).

\section{RESULTS}

\section{Patient 1}

Clinical data. J.V., a girl, was the first child of healthy, unrelated parents, At the child's birth, the father was 25 and the mother 23 years old. Pregnancy was normal but intra-uterine growth retardation was observed during the third trimester. Delivery, at term, was without difficulties. Birthweight was $2230 \mathrm{~g}$ and length $43 \mathrm{~cm}$. Shortly after birth, a chromosomal investigation was performed because of the association of pre-and postnatal growth retardation with a number of mild congenital stigmata. The facies was round with flat and broad nasal bridge, the nose was small and upturned. Palpebral fissures were small and in slight antimongoloid position. The philtrum of the upper lip was short, and the mouth triangular. The occiput was prominent and the neck was short. Hands and feet were small with clinodactyly of the Vth finger. Genital development was normal. Cardiological evaluation was normal. Psychomotor development was satisfactory within the first 4 months of life, although there was a tendency to hypertonicity with intermittent opisthotonus. Postnatal growth failure was pronounced: at the age of 3.5 months weight was $6400 \mathrm{~g}$ (P3 is 7900 ), length $63 \mathrm{~cm}$ (P3 is $70 \mathrm{~cm}$ ) and head circumference $41 \mathrm{~cm}(\mathrm{P} 3$ is $43.9 \mathrm{~cm}$ ). Now, at the age of $61 / 2$ years, weight is $12 \mathrm{~kg}$, length $86 \mathrm{~cm}$, and head circumference $46 \mathrm{~cm}$ (all values far below the third percentile). 
174 M. Borghgraef, F. P. Fryns and H. Van Den Berghe

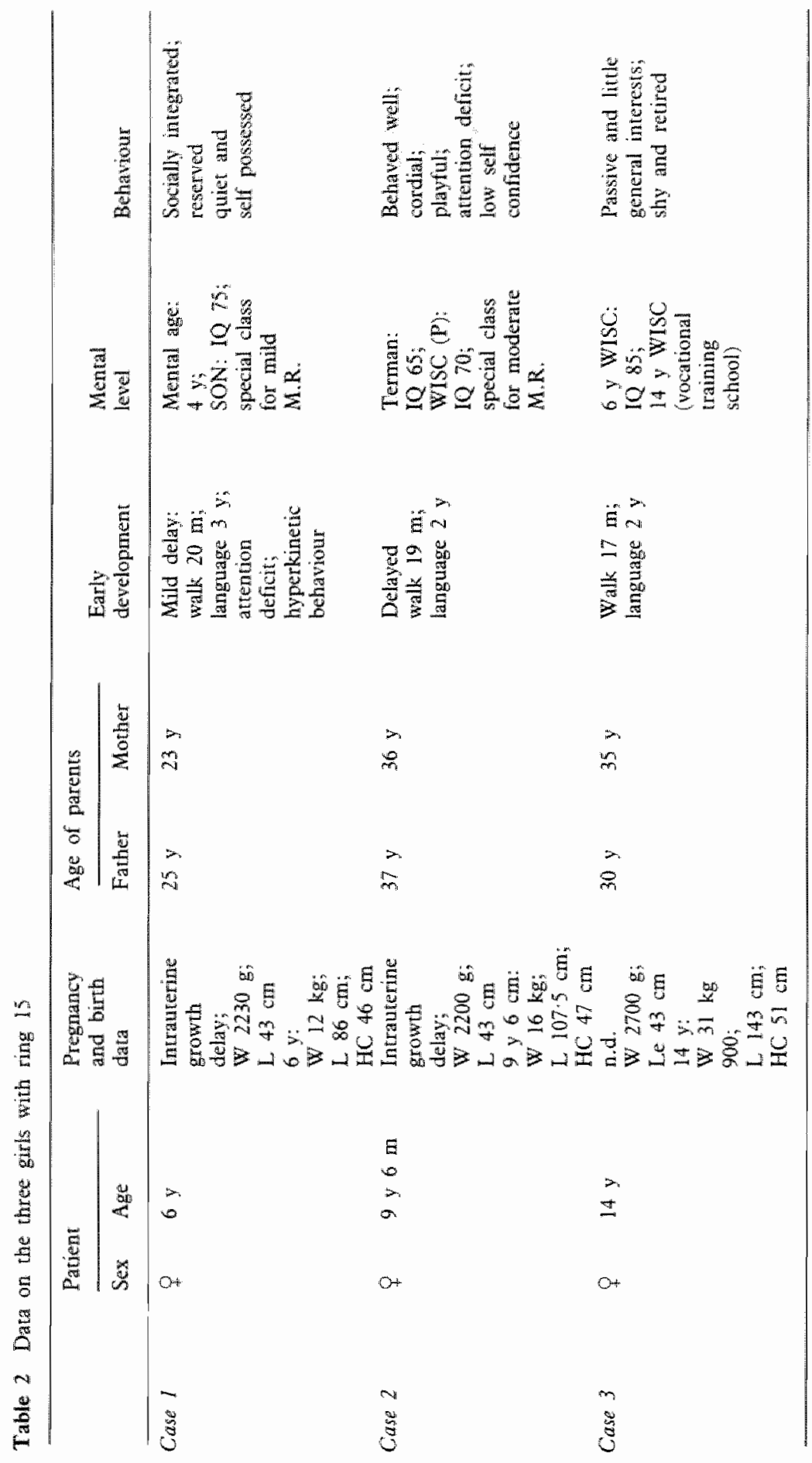


Cytogenetic data. A total number of 72 cells from two different lymphocyte cultures have been examined with different banding techniques ( $\mathrm{G}$-, $\mathrm{Q}$ - and $\mathrm{C}$-banding). In all cells, except in four in which there was random loss of one or more chromosomes, 46 chromosomes were found. A ring chromosome 15 was present in all cells. The ring appeared to be a stable, monocentric ring in 70 cells, in two cells a double ring was found. The breakpoints in the ring chromosome could be identified as $15 \mathrm{p} 12$, and $15 \mathrm{q} 24$ or 25 .

The karotype of both parents was normal (G-, Q-, C- and R-banding).

Psychological data. The age of onset of the gross motor milestones such as sitting up and walking was mildly retarded. The amount of babbling during the first year of life was diminished. At the age of 3 years, J.V. was integrated in a normal class, but a marked attention deficit and hyperkinetic behaviour problems caused serious problems. At the age of $6 \frac{1}{2}$ years, she was observed and examined at home with the SON performantial intelligence test. The results pointed out a mild mental retardation and school immaturity. The mental age level was $4 \frac{1}{2}$ years, the performantial IQ was 75 . The parents were recommended to send the child to a special class.

- Cognition: Verbal intelligence was very low, with poor language skills. On the more practical intelligence tests, J.V. performed the best in assortment and memory tasks. The basic terms for school skills were, in general, not yet acquired.

- The language developmental level was 3 years with only short two- to three-word sentences. She had problems to express herself and some speech defects were evident. There was understanding of only very simple verbal instructions.

- Behaviour and social intercourse: The child appeared to be rather passive with little general interests. Periodically she was extremely wilful and obstinate. In the presence of unfamiliar persons, she was fairly shy and retired.

\section{Patient 2}

Clinical data. V.L.E., a girl, was the first child of healthy, unrelated parents. "The father was 27 and the mother 26 years old at the child's birth. Pregnancy was normal but intra-uterine growth retardation was observed at the seventh month of gestation. Delivery, at term, was without problems. The birthweight was $2200 \mathrm{~g}$ and the length $43 \mathrm{~cm}$. This severe growth retardation was the indication to perform a chromosomal investigation.

There was general hypertonicity, with permanent flexion of all fingers, adduction deformity of both thumbs and a high-pitched cry. Only a few dysmorphic stigmata were at note: hypertelorism and broad nasal bridge, small nose and short neck. Growth deficiency progressively became more pronounced. Now, at the age of $91 / 2$ years, weight is $16 \mathrm{~kg}$, length $107.5 \mathrm{~cm}$ and head circumference $47 \mathrm{~cm}$. All these growth parameters are far below the third percentile for her age.

Cytogenetic data. A total of 41 cells from two different lymphocyte cultures were examined with different banding techniques ( $\mathrm{G}_{-}, \mathrm{Q}, \mathrm{C}$ - and $\mathrm{R}$-banding). In most 


\section{M. Borghgraef, 7. P. Fryns and H. Van Den Berghe}

cells, 46 chromosomes were found but, in four cells, there was a random loss of one or more chromosomes. A ring chromosome 15 was present in all cells. The ring chromosome appeared to be a stable, monocentric ring in 57 cells. In two cells, the ring was open and, in another two cells, a double ring was found. The breakpoints in the ring chromosome could be identified as $15 \mathrm{pl} 2$ and $15 \mathrm{q} 25$.

Psychological data. Early psychomotor development was delayed with later acquirement of locomotive milestones and of other skills as are grasping, drawing and the first words.

E.V.L. was sent to the infant school at the age of 3 years. During the next 4 years, school immaturity was evident and after that age she was integrated in a school for the moderately mentally retarded.

At the age of $91 / 2$ years, she was observed at home and tested with the Terman and WISC intelligence scale. She obtained an IQ of $65-70$ and was functioning on a mental age level of $61 / 2$ years.

- Cognition: the authors observed only small differences between the verbal and practical performances, with the best performance on analytical-synthetic and visuo-motor tasks (puzzles, block design, drawing). Rational thinking and general memory were less developed. At school, skills in reading and writing were acquired with more difficulty than arithmetical ones.

- Language: E.V.L. could express herself without difficulties and she spoke in full sentences with an extensive vocabulary. Her speech is fluent but somewhat too rapid.

- Behaviour and social intercourse were normal, and she behaved well and spontaneously. In addition, she was very cordial and playful. We observed, however, a marked deficit in attention and concentration. Task motivation and self confidence were low.

\section{Patient 3}

Clinical data. B.S., a girl, was the youngest of eight children. At the girl's birth, the father was 39 and the mother 35 years old. Pregnancy and delivery were normal. Birthweight was $2700 \mathrm{~g}$ and length $43 \mathrm{~cm}$. Delayed psychomotor development and growth failure were noticed from the beginning. At the age of $6^{1 / 2}$ years, she was sent to a paediatrician for a general physical investigation, because of school immaturity and growth failure.

Clinical examination revealed a somewhat oldish-looking girl, in whom the craniofacial stigmata were the most obvious. The face was triangular with retrognathism, high-arched palate and small carious teeth. No other malformations were obvious. The hands and feet were small, with marked brachymesophalangy of the fingers. Cardiac evaluation was normal. Routine biochemical and endocrinological evaluation was normal. The bone age reflected the chronological age.

Now, at the age of 14 years, her weight is $31 \mathrm{~kg} 900 \mathrm{~g}$, length $143 \mathrm{~cm}$ and head circumference $51 \mathrm{~cm}$. Pubertal development is normal with normal menstruation cycle. 
Cytogenetic data. A total of 60 cells were examined with different banding techniques (Q-, G-, C- and R-banding). In 56 cells, 46 chromosomes were found. In all these cells, a ring chromosome 15 was present. In the remaining four cells, 45 chromosomes were found, with loss of the ring chromosome. The size of the ring chromosome was variable. In 28 cells, it was small, monocentric and stable, whereas, in 27 cells, the ring was double. In one cell, an open ring was found. The breakpoints were identified as $15 \mathrm{p} 11$, and $15 \mathrm{q} 22$ or 23 . The karyotype of both parents was completely normal ( $\mathrm{G}$-, Q-, C- and R-banding).

Psychological data. The history of development and behaviour was not fully remembered by the parents but a delay in early psychomotor development was observed. The girl went to regular infant and elementary school. A first psychological testing was performed at the age of $6 \frac{1 / 2}{2}$ years and pointed out an IQ of 85 . B.S. was evaluated as an underachiever, school immature with speech problems and poor visual discrimination. She doubled the first year of elementary education but in the next years no major problems were noted. At the age of 14 years, she was tested (WISC) and the results confirmed the previous findings: borderline mental level with learning problems, IQ was 84 . At the present time, she attends a vocational training school.

Cognition: There was a clear difference between verbal and practical performances: verbal IQ was 80, performantial IQ 92. Psychomotor performance, visual discrimination and analytical synthetic abilities were better developed than knowledge of facts, reasoning and detail analysis.

Language: B.S. spoke easily and had a wide vocabulary. Pronunciation was sometimes unclear because of a rapid speech rhythm.

- Behaviour and social intercourse: Social integration is normal and autonomy is complete. B.S. is somewhat shy and reserved, but quiet and self-possessed.

\section{DISCUSSION}

Since the introduction of the chromosomal banding techniques, at least 26 patients with ring chromosome 15 were reported. Of these, only four were adults. In most patients, a chromosomal aberration was suspected because of severe growth failure associated with mental retardation. In addition, ring chromosome 15 patients present mild dysmorphic stigmata. Although somewhat variable from patient to patient, the clinical syndrome can be delineated as follows: triangular face with hypertelorism, small mouth and thin lips, microretrognathism, small hands and feet with clinodactyly of the $V$ th fingers, and short neck. The female/male ratio is $3 \cdot 3 / 1$. The mean paternal and maternal ages at birth are 32 years and 29 years, respectively. Birth measurements were low in most patients: weight $2.300 \mathrm{~kg}(<\mathrm{P} 3)$ and length $47.8 \mathrm{~cm}$ (=P3). In all patients, the first psychomotor development is mild to moderately retarded: the ages of onset of sitting up (means 12 months), walking (24-30 months) and first words ( $3 \frac{1}{2} / 2$ years) were delayed. In four reported patients, mental retardation is severe. While neurological complications are rare in ring chromosome 15, epileptic seizures were noted in three of the severely mentally retarded (Benadiba et al., 1981; Fryns et al., 1986; Kiss \& Osztovics, 1982) (Table 1). 


\section{M. Borghgraef, J. P. Fryns and H. Van Den Berghe}

A review of the data on $\mathbb{I Q}$ determinants reported in the literature reveals the following distribution: $15 \%$ of the patients reported are intellectually normal to feebleminded (IQ> 74), 25\% are mildly mentally retarded (IQ 68-52), 45\% have moderate mental retardation (IQ $51-36$ ) and $15 \%$ are severely mentally retarded (IQ 35-20). The present three patients belong to the upper category with IQs of 85,75 and 65 , respectively. Few data are available on the cognitive profile of children and adults with ring 15 syndrome. The authors observed a somewhat dysharmonious profile in the present three children with ring 15: the performantial level (analytical synthetic and visuo-motor tasks) was higher than the level of verbal abilities. Language and speech difficulties were pronounced around the age of 4-6 years, but these problems disappeared a few years later. The two oldest girls could express themselves well and spoke fluently. The speech rhythm was rapid, however, and, in all three patients, attention and concentration were poor.

By the observation of behaviour and social skills in the present three patients, the authors perceived them as cordial, docille children and young adults with positive social integration. Except the youngest girl, the parents told that these children have very few moments of obstinating and revolting behaviour. Because of the short stature with delicate bodybuild and developmental delay, they are more and for longer time mothered by their entourage (Table 2 ).

In the literature, two patients were reported with aggressive and difficult behaviour (Stoll et al., 1975; Benadiba et al., 1981). They were both severely retarded. Jacobsen (1966) described an adult male patient as childish, speech impulsive, perseverating, with rapid alteration in mood. Rumenic et al. (1976), Pfeiffer (1977) and Scheibenreiter \& Frisch (1978) perceived their patients in general as willing, interested and with good social integration. The present data confirm that, despite the severe growth failure of patients with ring chromosome 15, social integration and functioning may be satisfactory in the majority of cases.

Most patients with chromosome aberrations are extensively reported on clinical and cytogenetical data. Up to now, little attention has been payed to the psychomotor and mental development in patients with autosomal abnormalities. A further careful collection of the clinical and psychological data in these patients is urgently needed to extend the knowledge on their natural history and long-term physical and mental prognosis.

\section{REFERENCES}

Benadiba M., Hamon J., Fausser C. \& Helmlinger W. (1981) Anomalie chromosomique et déficience mentale. Etude d'une observation de chromosome 15 en anneau. Neuropsychiatrie de PEnfance et de l'Adolescence 29, 631-9.

Emberger J.M., Ross D., Jean R., Bonnet H. \& Dumas R. (1971) Etude d'une observation de chromosome du groupe 13-15 en anneau $(46, \mathrm{XY}, 15 \mathrm{r})$. Human Genetics 11, 295-9.

Ferrante E., Boscherini B., Bruni L., Vignette P. \& Finocchi G. (1977) La sindrome r(15) Minerva Pediatrica 29, 2163-8.

Forabosco A., Dutrillaux B., Vazzoler G. \& Lejeune J. (1972) Chromosome 15 en anneau: r(15). Identification par dénaturation ménagée. Annales de génétique 15, 267-70.

Fryns J.P., Jaeken J., Devlieger H., Debucquoy P., Eggermont E. \& Van Den Berghe H. (1981) Ring chromosome 15 syndrome. Acta paediatrica Belgica 34, 47-50. 
Fryns J.P., Timmermans J., D'Hondt F., Françớs B., Emmery L. \& Van Den Berghe H. (1979) Ring chromosome 15 syndrome. Hwman Genetics $51,43-8$.

Fryns J.P., Kleczkowska A., Butriens M., Jonckheere P., Brouckmans-Buttiens $\mathbb{K}$. \& Van Den Berghe H. (1986) Ring chromosome 15 syndrome. Further delineation of the adult phenotype. Anvales de génétique 29, 45-8.

Fujita H. \& Matsumoto H. (1978) Ring chromosome $15 ; 46, X X, r(15)(p 11 ; q 26)$ in a girl. Nippon Romen Igakkai Zasshi 23, 233-7.

Gardner R.J.M., Chewings W.E. \& Holdaway M.D. (1980) A ring 15 chromosome in a gir] with minor abnormalicies. New Zealand Medical Joumal 91, $173-4$.

Jacobsen P. (1966) A ring chromosome in the 13-15 group associated with microcephalic dwarfism, mental retardation and emotional immaturity. Hereditas 55, 188-91.

Kiss P. \& Osztovics M. (1982) Ring chromosome 15. Acta paediatrica Academäa Scientarwm Hungaricae 23, 409-15.

Kousseff B.G. (1980) Ring chromosome 15 and failure to thrive. American Foumal of Diseases of Children 134, 798-9.

Ledbetter D.H., Riccardi V.M., Au W.W., Wilson D.P. \& Holmquist G.P. (1980) Ring chromosome 15: phenotype, Ag-NOR analysis, secondary aneuploidy and associated chromosome instability. Cytogenetics and Cell Genetics 27, $111-22$.

Meinecke P. \& Koske-Westphalt T. (1980) Ring chromosome 15 in a male adult with radial defects. Evaluation of the phenotype. Clinical Genenics 18, 428-433.

Moreau N. \& Teyssier M. (1982) Ring chromosome 15: report of a case in an infertile man Clinical Genetics 21, 272-9.

Otto J., Back E., Fürste H.O., Abel M., Böhm N.\& Pringsheim W. (1984) Dysplastic features growth retardation, malrotation of the gut and fatal VSD in a 4-month-old girl with $\mathrm{r}(15)$. European Journal of Pediatrics 142, 229-31.

Pfeiffer R.A., Dhadial R. \& Lenz W. (1977) 46,XX/46,XX,r(15) mosaicism. Foumal of Medical Genetics 13, 63-5.

Rumenic L.J., Joksimovic I. \& Anaf F. (1976) Ring chromosome 15 in a child with a minor dysmorphism of phenotype. Human Genetics 33, 186-8.

Scheibenreiter S. \& Frisch H. (1978) Ein Kind mit Ringchromosome 15. Wiener klinische Wochenschrifi $90,22-5$.

Schmid M., Henrichs I., Nestler H., Knörr-Gärtner H., Teller W.M. \& Krone W. (1978) Analysis of banding patterns and mosaic configuration in a case of ring chromosome 15 Human Genetics 41, 289-99.

Stoll C, Juif J.G., Luckel J.C. \& Lausecker C. (1975) Ring chromosome 15:r(15). Identification by $\mathrm{R}$ banding. Human Genetics 27, 259-62.

Wisniewski L., Pronicka E., Lech H. \& Niezabitowska A. (1979) The child with chromosome ring 15. Klinische Pädiatrie 191, 429-32.

Yunis E., Leibovici M. \& Quintero L. (1981) Ring (15) chromosome. Human Genetics 57, $207-9$.

Received 2 April 1987

p. 170. Table 1. Patient 3: $0-2 y=2$ y; $0-36 \mathrm{~m}=36 \mathrm{~m}$

p. 174. Table 2. Case 2. Age parents $37 y=27 y ; 36 y=26 y$

Case 3. Age parents $30 y=39 y$

p. 176. Second paragraph - alinea 8:

$\ldots$ an 10 of $65-70$ is

$\ldots$ an 10 of $65-70$ respectively 



\section{DISCUSSION AND CONCLUSIONS}

\section{Autosomal syndromes}

Autosomal syndromes are known to be associated with clinically recognizable symptoms and stigmata and a variable degree of mental retardation (Schinzel, 1981). Little is known, however, about the psychological profile of these patients. As for the fra $(X)$ patients a better knowledge of their intellectual and behavioural functioning was found to be an important factor towards diagnosis, which may lead to the start of effective early stimulation programs at early age.

This is most clearly illustrated in our study of a group of 12 patients with Prader-Will syndrome. Over the past years it has become evident that their strong leaning to obesity not only affects their general physical condition and health but also has a strong negative psychological impact. In half of the patients the definite diagnosis of Prader-Willi syndrome was made before the age of one year. Parents and educators were fully informed about the tendency to hyperphagia and subsequent behavioural problems as are fugues, stealing of food, moodiness and psychotic reactions. All patients were mildlly to moderately mentally retarded (IQ's between 45 and 92). Verbal intelligence was higher than performantial functioning in $2 / 3$ of them, due to the severe hyptonia and motor delay. Behavioural disturbances started from the age of 5-6 years on and increased markedly with age. The present study shows that full information of parents and educators about the medical and psychological consequences of the syndrome in their children of young age clearly prevents the majority of the above mentioned problems and gives strong support in coping with the disabilities related to the syndrome.

The longitudinal study of the physical and psychological development of three prepubertal girls with ring chromosome 15 revealed a severe, prenatal onset growth deficit associated with characteristic triangular face, small hands and feet and mild mental retardation. Social integration was satisfactory and major behavioural problems were not observed. This study stresses the importance of cytogenetic studies in patients with psychomotor delay and so-called "Silver-Russell phenotype" and illustrates that the differential diagnosis between Silver-Russell syndrome and ring chromosome 15 is impossible on clinical grounds only.

In a study of two children with mosaic full trisomy 8 and one child with partial trisomy of the short arms of chromosome 8 (dupllication of bands 8 p21.1-8p11) we observed a striking similarity of the phenotypic abnormalities associated with both conditions. The intellectual functioning 
and soclal development, however, was very different in both syndromes: the child with $8 \mathrm{p}$ duplication showed moderate to severe psychomotor delay with spastic diplegia, whereas the two children with mosaic full trisomy 8 performed at a borderline level and reached normal social integration.

The study of these 3 different autosomal syndromes thus revealed a different pattern of behaviour "development and mental fucntioning in all of them, assoclated with clinically recognizable phenotypic abnormalities. The study of the psychological profile of children with a precise etiology of mental retardation may lead to the identification of distinct subtypes of learning disabilities and may help to elucldate the role of the chromosomes and their genes in normal cognitive development. Although the groups of patients are too small to make definite, general conclusions. It is clear that the present study gives a first indication of the fact that a better concise description of the developmental characteristics in these conditions is of major importance in early dlagnosis, treatment and prevention.

\section{Reference}

Schinzel A. Particular behavioral symptomatology in patients with rarer autosomal chromosome aberrations. In: W. Schmid \& J. Nielsen (Eds.), Human Behavior and Genetics. Elsevier/North-Holland Biomedical Press, 1981, pp. 195-210. 
. 

GENERAL CONCLUSION, AND PERSPECTIVES FOR THE FUTURE 

The Centre for Human Genetics of the University of Leuven runs a very active genetic clinic, attended by patients and families for genetic diagnosis and counseling. There is a great diversity of counseling problems and mental retardation is the most frequent indication for referral. Mental retardation can be caused by many different factors. Hereditary or nonhereditary factors can be involved.

Rightly so every mentally retarded person has the right to an extensive clinical examination by a multidisciplinary team in order to arrive at an outline of his problems and needs and preferably at a final diagnosis.

The genetic clinic in Leuven works not only as a medical diagnostic and genetic counseling centre but provides "a total care" of the consulting family with medical, social and psycho-educational follow-up. High quality support and help can only be offered if they are based on a firm scientific background.

This approach forced us, as a special educator working at this Centre and with the theory of "special education" in mind, to start thorough scientific research of the "different ways of being and behaving of the mentally retarded child". This theory defines the pedagogical approach of mental retardation as to "enter into a relationship with the mentally retarded, supported by a fundamental consideration, where-in the development of his total person is aimed in view of the advance of his well-fare".

Being interested in the question whether mental retardation of constitutional, genetic origin is characterized by specific profiles of cognitive development, learning disabilities and/or behavioural disorders and with the aim to get a better understanding of the forces and events important in the pathogenesis of psychosocial problems in the group of the mentally retarded, we started the study of the psychological profiles and behavioural characteristics of children with specific chromosomal disorders.

Mental retardation is primarily a cognitive disorder with secondary effects on personality and emotions.

From the beginning we considered the distinction between these two basic psychological processes, and carefully analyzed the cognitive or intellectual processes, such as thinking and memory, and the emotional, motivational and personality processes such as anxiety, love and feelings.

Etiological research on mental retardation has shown that the fra $(X)$ syndrome along with Down's syndrome is the most important cause of mental retardation.

Patients with the fra $(X)$ syndrome were the first group of which we collected growing information on and knowledge of their psychological profile and defined strategies to work efficiently with these children and their families. 
Fra $(X)$ patients express a recognizable clinical phenotype. The craniofaclal aspect and macro-orchidism are the features that are involved, showing varlability in expression. But this phenotype is less clear in younger children, l.e. prepubertal patients. It became evident that a better knowledge of the psychologlcal characteristics of $\mathrm{fra}(\mathrm{X})$ boys could be more helpful diagnostically than the physical features.

Most of the fra $X$ boys were found to be moderately mentally retarded. An important observation was the negathe correlation between age and level of Intellectual functioning. This finding seemed to indicate a decline in intelligence performances with age. There were no arguments to explain this decline by a deterioration or loss of acquired abilities. A more plausible explanation was that these mentally retarded boys learn at a slower rate than expected from their inttlal $I Q$ and that this might be induced by their behavioural problems. Hyperkinetic behaviour (or ADHD) was twice more common in fra $X$ boys compared to fra $(X)$ negative, physically normal males with the same degree of mental retardation, and autistic features were found in $30 \%$ of the fra $X$ males.

Thls study conflrmed the presence of a distinct pattern of developmental and behavioural characteristlcs in young fra $X$ males which may be much more specific than the clinical spectrum.

Further research on the developmental characteristics in these children should be focussed on two types of questions. The first question concerns the study of the developmental changes I.e. how childrens behaviour and abilities change as they grow older. In the second question the factors influencing these changes are at study.

Important topics for further reserach in the fragile $X$ syndrome are therefore:

1. The collection of precise longltudinal, longterm follow-up data on intelligence in the group of young fra $(X)$ boys. Therefore we started a yearly physical and psychological evaluation in 20 fra $(X)$ positive boys now aged between 1 and 6 years.

2. At the same time, the age-dependency of the assoclated behavioural problems l.e. Attention Deficlt Hyperkinetic Disorder and autistic reactions will be clarifled. The observed changes in the behavioural pattern with age will be correlated with the evolution of their biological growth and neuroendocrinological and neurophysiological changes.

3. A thorough psychoneurological study of fra $(X)$ females has been started. It should provide important new data towards a better knowledge of the physical and psychological characteristics of this population. These data are urgently needed as early diagnosis of at risk females is highly important towards accurate genetic counseling.

4. The investigation of the psychological characteristics is important for educational and therapeutic programs. We recently started a 
multidisciplinary study group for this purpose of the elaboration of early stimulation programs and strategies to work efficiently with these children at school.

5. Since little is known about the effect of the surroundings and the parentfra $(X)$ child interaction on the intellectual and social-emotional development, more research in this direction is recommended.

In the study of patients with sex chromosomal disorders (Part II A) we further delineated the physical, cognitive and behavioural development in children with various types of $X$ - and $Y$-chromosome polysomies. We reported the follow-up data of clinical observation, registration and psychometric testing in 8 young males with $49, X X X X Y$ syndrome, 4 males with $48, X X Y Y$ syndrome and 3 ginls with $48, X \times X X$ syndrome. In addition to the systematic testing performed in these patients, psychiatric evaluation was made in these childern to get information about their psychosocial problems. An interesting finding was the specific effect of these different sex-chromosomal aneuploidies on the individual physical and psychologlcal development. The $49, X X X X Y$ boys had in addition to a mild to severe mental retardation, slight emotional problems like shyness, anxlety and low frustration level. The $48, X \times Y Y$ boys performed at a higher Intellectual level but presented serious behavioural disorders and personality disturbances. They were admitted for one or several observation periods in psychlatric hospitals and needed continuing intense therapeutic guidance. And finally the $48, X X X X$ girls had a mild to moderate mental retardation and were somewhat anxious and shy. The present study glves further evidence that the risk for mental retardation and physical defects in males with the "rare" sex chromosome aneuplaidies primarlly increase with the number of extra $X$ chromosomes, and only in a second order with the number of extra Y's, which are apparently more related to behavioural problems. The study of a possible relationship between psycho-pathological abnormalities and sex chromosome aneuploidles is partlcularly fascinating. Topics for further research are the importance of prospective studies, on larger groups and in group of patients with other sex chromosomal aneuploldles. This research is a major instrument to clarify the relationship between $X$ - and $Y$ chromosomes and physical "cognitive and behavioural features.

In the evaluation of children and adults with different autosomal syndromes (Part II B) we raised the question whether they presented a characteristic behavioural profile related with the chromosomal abnormality.

We examined children and adults with three different autosomal syndromes l.e. trisomy 8 mosaicism, ring chromosome 15 and Prader-Willi syndrome (with and without detectable 15q11 deletion) and found a distinct pattern of 
developmental abnormalities associated with a clinically recognizable phenotype. This is most clearly illustrated in the study of 12 patients with Prader-Willi syndrome. All were mildly to moderately mentally retarded. Behavioural problems, mostly related to their boulemia, were present and increased with age, like moodiness, psychotic reactions and outburst of anger.

A longitudinal study of the physical and psychological development of prepubertal girls with ring chromosome 15 revealed a severe, prenatal onset growth deficit associated with characteristic face, small hands and feet and mild mental retardation.

The study of children with a partial and full trisomy of chromosome 8 illustrated the striking similarity of the fenotype of these patients with both conditions, and on the other hand the great differences in level of intellectual functioning and social development.

The present results on other chromosomal syndromes are the first of an ungoing project and call for further research, on larger groups and on a longitudinal basis, in mentally retarded children with different types of autosomal anomalies. At the Center of Human Genetics of Leuven a constitutional chromosomal analysis has been performed in \pm 80.000 patients in the period 1965-1990 and, furthermore, more than 4,500 new patients are added each year. This gives us the opportunity and the privilige to continue not only follow-up studies in the large group of patients with different chromosomal abnormalities presented in this thesis, but to start a similar research in patients with other chromosomal rearrangements and changes.

The study of the psychological profile of children with a precise etiology of mental retardation may lead to the identification of distinct subtypes of learning disabilities and may help to elucidate the role of the chromosomes and their genes in normal cognitive development.

In the present study this scientific approach will further be integrated in practical help and support to the children, their parents and families. Moreover, the present study confirms the important long-term consequences of the dlagnosis of a chromosomal abnormality as the cause of mental handicap in a child. Early diagnosis in the child opens the possibilities towards the start of early intervention and stimulation programs based on a precise knowledge of the demands and needs of the child with this specific syndrome and gives the opportunity to inform parents about actual problems, longterm prognosis and problems in their child. If well informed, these parents will become most competent, special educators of their own child. It is needless to explain the tremendous positive importance of this approach in the process of accepting the child's 
handicap by the parents. The care and guidance to the parents involves first of all to give them complete information about the medical and psychological prognosis. Clearness about the etiology and information about what can be expected will considerably reduce stress, anxiety and tension in the familly.

The possibility of practical help and support to the family reinforces the philosophy of the Center for Human Genetics i.e. the best help is not good enough, and can only be effective and accurate if it is based on a firm scientific basis. 

APPENDIX: Materials and Methods 


\section{APPENDIX : Materials and Methods}

\section{Psychometric testing and behavioural observations}

The growing interest in the study of and research of the psychological profile and behavioural characteristics of the mentally retarded has resulted in a progressive increase of specific requirements of the testing materials and observation scales. The heterogeneity in abilities and disabilities of this population raised the necessity of handling different tools to measure the same (dis)abilities.

Being thoroughly aware that these instruments and the clinical observation of the behaviour of the children of this study, present several methodological incompletenesses, we firmly opted to introduce a control group of mentally retarded children matched as good as possible for age and mental level. We submitted them to evaluations and observations with the same instruments and scales as those used for the experimental group, and completed some statistical comparisons.

These comparisons of results obtained in both groups of patients gave us the opportinity to make some observations stronger and conclusions more valid.

In a first paragraph we present an extensive definition and description of the different abilities and disorders which we intended to registrate and evaluate, and in a second we discuss the testing materials and observation methods used during this study.

\section{A. Mental Retardation - (cfr. DSM III Axis II) (American Psychiatric Association, 1987) \\ 1. Definitions}

According to the DSM III Axis II the essential features of this disorder are: "(1) significantly subaverage general intellectual functioning, accompanied by (2) significant deficits or impairments in adaptive functioning, with (3) onset before the age of 18 .

General intellectual functioning: general intellectual functioning is defined as an intelligence quotient (IQ or IQ equivalent) obtained by assessment with one or more of the individually administered general intelligence tests. Significantly subaverage intellectual functioning is defined as an IQ equal or below 70 .

Degrees of severity: four degrees of severity, reflecting the degree of intellectual impairment i.e. mild, moderate, severe and profound are defined. 
The IQ-levels used as guides in distinguishing the four degrees of severity are:

$\begin{array}{ll}\text { degree of severity } & 10 \\ \text { mild } & 50-55 \text { to } \pm 70 \\ \text { moderate } & 35-40 \text { to } 50-55 \\ \text { severe } & 20-25 \text { to } 35-40 \\ \text { profound } & \text { below } 20-25\end{array}$

In Belgium and the Netherlands the cut off score was put on IQ 80 in the practice of ascertaining mentally retarded people (Dumont 1971, Hellinckx 1973).

"Adaptive functioning: adaptive functioning refers to the person's effectiveness in areas such as social skills, communication and daily living skills, and evaluates how well he meets the standards of personal independence and social responsibility expected of his or her age by his or her cultural group."

\section{Testing materials}

The valuation of IQ-tests on hand useful for the population of mentally retarded was not a simple concern. An individually administered $1 Q$ test intended to measure the general intellectual functioning of a subject and to delineate the structure of the intelligence. The Wechsler-scales are one of the best tools to assess intellectual functioning (Stinissen \& Van der Steene, 1970; Van Haasen et al., 1985; Stinissen et al., 1970). These scales (WPPSI; WISC; WAIS) are built up on the distinction between verbal and performantial intelligence and, by subtests-analysis, these scales give, up to now, the most useful analytic method for the different intellectual factors (Dumont, 1985; Krajer, 1978). The Wechsler-scales are also applicable in a wide range of ages ( 4 years to adult age) and mental levels.

In some patients we could dispose of the results of testing on the TermanMerrill intelligence test (Terman \& Merrill, 1973). This scale was also suitable for mentally retarded and applicable in a wide range of ages. This intelligence test had the advantage to be very useful for retesting over short intervals. In general, the results on Wechsler-scales and the Terman-Merril intelligence test for the same patient are very comparable, and the mean correlation is 0.82 (Stinissen, 1965; Sattler, 1974, Sattler, 1988).

Very young children (baby's and toddlers) were tested with the Bayleyscales of Infant Development (Nan der Meulen \& Smrkovsky, 1975). These 
scales allow the ascertainment of the present level of mental and motor development in children between the age of 2 to 30 months. At the same time these scales are suitable for the assessment of the mental functioning of severely mentally retarded. In addition to the determination of the mental and motor developmental level, these scales offer also the possibility of a quantitative and qualitative interpretation of the behaviour (Van der Meulen \& Smrkovsky, 1975).

The use of the SON-intelligence test (Snijders \& Snijders-Oomen, 1975) was necessary in those patients with no or very limited language development. The results on this test are frequently a mild overestimation of the intelligence capacities of a person, and have to be interpreted with caution.

For the evaluation of the adaptive functioning capacities of a child we mostly used the PAC11-PAC2 (Günzburg 1977), combined with personal observations and the story of parents and other educators. In classifying our patients in mildly, moderately, severely and profoundly retarded, we also take the degree of adaptive functioning into account.

\section{B. Attention-deficit Hyperactivity Disorder - DSM III 314.01 ADHD} (American Psychiatric Association, 1987)

\section{Definition}

"The essential features of this disorder are developmentally inappropriate degrees of inattention, impulsiveness, and hyperactivity. They are manifested, in a variable degree, in most situations, e.g. home, school, work and social situations."

"ADHD features are frequently observed in the mentally retarded and are secondary to their generalized delay in intellectual development. The additional diagnosis of $A D H D$ is made only if the relevant symptoms are excessive for the child's mental age."

"Criteria: a disturbance of at least six months during which at least eight of the following are present:

(1) often fidgets with hands or feet or squirms in seat (in adolescents, may be limited to subjective feelings of restlessness)

(2) has difficulty remaining seated when required to do so

(3) is easily distracted by extraneous stimuli

(4) has difficulty awaiting turn in games or group situations 
(5) often blurts out answers to questions before they have been completed

(6) has difficulty following through on instructions from others (not due to oppositional behavior of failure of comprehension) e.g., fails to finish chores

(7) has difficulty sustaining attention in tasks or play activities

(8) often shifts from one uncompleted activity to another

(9) has difficulty playing quietly

(10) often talks excessivelly

(11) often interrupts or intrudes on others " e.g." butts into other children's games

(12) often does not seem to listen to what is being said to him or her

(13) often loses things necessary for tasks or activities at school or home (e.g. toys, pencills, books, assignments)

(14) often engages in physically dangerous activities without considering possible consequences

Age-specific features: In preschool children, the most prominent features are generally signs of gross motor activity, such as excessive running or climbing. The child is often described as being on the go and 'always having his motor running". Inattention and impulsiveness are likely to be shown by frequent shifting from one activity to another. In older children and adolescents, the most prominent features tend to be excessive fidgetting and restlessness rather than gross motor overacivity. These may contribute to fallure to complete assigned tasks or instructions."

\section{Testing Material - Observation scale}

Clinical observation of this behavioural pattern is the first indication for the eventual presence (or absence) of the ADHD, but it does not exclude some subjectivity in the judgement. Extra diagnostic assessment by more objective scoring materials is necessary to determine the ADHD. Therefore we decided to use the "Behaviour-observation lists for study of children with possible MBD" (Dutch adaptation of the Conners-lists). Within this instrument, extant of three observation-lists for respectively the parents, the teachers and the therapists, a number of behavioural characteristics have to be judged according to the gravity and frequency of the characteristic in the child. Specific assessment of the attention and concentration function was indicated as well. The Wechsler scales permit to evaluate this function by analysis of the results on the subtests 'coding', 'arithmetic' and 'digit span'. 
C. Autistic disorder / Features - DSM III 299.00 (American Psychiatric Association, 1987)

\section{Definition}

"Pervasive Developmental Disorder with onset in infancy or childhood

Qualitative impairment in reciprocal social interaction as manifested by the following:

(1) marked lack of awareness of the existence or feelings of others (e.g., treats a person as if he or she were a plece of furniture; does not notice another person's distress; apparently has no concept of the need of others for privacy)

(2) no or abnormal seeking of comfort at times of distress (e.g., does not come for comfort even when ill, or tired; seeks comfort in a stereotyped way (e.g. says "cheese, cheese, cheese").

(3) no or impaired imitation (e.g., does not wave bye-bye; does not copy mother's domestic activities; mechanical imitation of others' actions out of context)

(4) no or abnormal social play (e.g., does not actively participate in simple games; prefers solitary play activities; involves other children in play only as "mechanical aids")

(5) gross impairment in ability to make peer friendships (e.g., no interest in making peer friendships; despite interest in making friends, demonstrates lack of understanding of conventions of social interaction, for example, reads phone book to uninterested peer).

Qualitative impairment in verbal and nonverbal communication, and in imaginative activity, as manifested by the following:

(1) no mode of communication, such as communicative babbling, facial expression, gesture, mime, or spoken language

(2) markedly abnormal nonverbal communication, as in the use of eye-toeye gaze, facial expression, body posture, or gestures to initiate or modulate social interaction (e.g., does not anticipate being heid, stiffens when held, does not look at the person or smile when making a social approach, does not greet parents or visitors " has a fixed stare in social situations)

(3) absence of imaginative activity, such as playacting of adult roles, fantasy chatacters, or animals; lack of interest in stories about imaginary events

(4) marked abnormalities in the production of speech, including volume, pitch, stress, rate, rhythm, and intonation (e.g., monotonous tone, 
questionlike melody, or high pitch)

(5) marked abnormalities in the form or content of speech, including stereo-types and repetitive use of speech (e.g., immediate echolalia or mechanical repetition of television commercial); use of "you" when "I" is meant (e.g., using "You want cookie?" to mean "I want a cookie"); idiosyncratic use of words or phrases (e.g., "Go on green riding" to mean "I want to go on the swing"); or frequent irrelevant remarks (e.g." starts talking about train schedulles during a conversation about sports)

(6) marked impairment in the ability to initiate or sustain a conversation with others, despite adequate speech (e.g., indulging in lengthy monologues on one subject regardlless of interjections from others)

Markedly restricted repertolre of activities and interests, as manifested by the following:

(1) stereotyped body movements, e.g., hand-flicking or -twisting, spinning, head-banging, complex whole-body movements

(2) persistent preoccupation with parts of objects (e.g., sniffing or smelling objects, repetitive feeling of texture of materials, spinning wheels of toy cars) or attachment to unusual objects (e.g., insists on carrying around a plece of string)

(3) marked distress over changes in trivial aspects of environment, e.g., when a vase is moved from usual position

(4) unreasonable insistence on following routines in precise detail, e.g., insisting that exactly the same route always be followed when shopping

(5) markedly restricted range of interests and a preoccupation with one narrow interest, e.g. interested only in lining up objects, in amassing facts about meteorology, or in pretending to be a fantasy character"

\section{Testing materials - Observation scales}

Beside clinical observation of the different diagnostic criteria items of the DSM III definition, we choose for the use of the Auti-scale (Van BerckelaerOnnes, 1981) and PEP scale (Schopler E., 1982). Within both instruments, parents and therapists of the child have to fill in a list of behavioural characteristics in different situations. Both scales allow to ascertain the child's specific behaviour as being in the autistic range or not. 


\section{Cytogenetic nomenclature and Technics}

The 46 chromosomes of man, present as 23 homologous pairs, have been classified on several occasions.

At the Denver Conference held in 1960 the chromosomes were classified in groups on the basis of their variations in size and position of the centromeres. The chromosome pair numbers were arranged consecutively from 1 to 22 , with the sex chromosomes designated by the symbols $\mathrm{X}$ and Y.

At the Paris conference, held in 1971, numerous new recommendations were made. Especially recommendations for the various banding patterns and standardization of the idiograms, that is, the nomenclature for each band. Since then, at regular intervals updates of this system are published under the title: I.S.C.N. International System for Human Cytogenetic Nomenclature.

A summary of the most important terms and abbreviations is given here:

Karyogram: a systematic arrangement of the chromosomes into various groups according to size, centromere location and banding patterns obtained after differential staining procedures.

Karyotype: a description of the total number of chromosomes, the sex chromosome complement and the eventually present abnormalities of the chromosomes in a cell or an individual.

Band: the definition of band has been given as a part of a chromosome clearly distinguishable from adjacent parts by virtue of its lighter or darker staining intensity. Bands are numbered consecutively from the centromere outwards along each chromosome arm.

$p$ and q: These symbols are retained to designate, respectively the short and long arms of each chromosome.

\section{Numerical Abnormalities}

All numerical abnormalities are indicated by + or - signs followed by the chromosome number. If a numerical abnormality is present together with a structural abnormality, the same symbols are used followed by the description of the structurally altered chromosome(s).

\section{Structural Abnormalities}

Two systems are available for designating structural abnormalities. In the short system the nature of the rearrangement and the breakpoint(s) are 
identified by the band(s) in which the breaks(s) occur(s).

The detalled system, besides identifying the type of rearrangement, defines each abnormal chiromosome present in terms of its band composition.

The most important abbreviations and symbols used are the following:

del : deletion; loss of a chromsome part

$t$ : translocation; exchange of parts of different chromosomes

dup : duplication; a chromosome part is twice present in the same chromosome

der : symbol to designate unbalanced translocation product

mat : the abnormal chromosome is derived from the mother

pat: the abnormal chromosome is derived from the father

$r$ : ring chromosome

;: separates chromosome areas involved in structural changes

() : includes structurally altered chromosomes

+ : before the appropriate symbol means additional whole chromosome

-: before the approprlate symbol means missing whole chromosome

+ : after the appropriate symbol mains increase in length of chromosome arm

- : after the appropriate symbol means decrease in length of chromosome arm

\section{Chromosome Banding}

The metaphase chromosomes may be stained with many different stains. A number of methods reveal a pattern of bands along the length of the chromosomes. This pattern is unique for every individual chromosome, permitting the identification of the chromosomes. Furthermore, abnormalities of the chromosomes with respect to number and structure can be identified.

Q-banding : the first differential staining technique introduced by Caspersson et al. in 1969 and carried out with the fluorescent dye Quinacrine mustard. The much less expensive and easily obtainable antimalarial drug Quinacrine hydrochloride, or atebrine, reveals the same Qbanding pattern. The method is often used to demonstrate the presence of the $Y$-(hetero)chromatin (Fig. 1).

G-banding : this type of banding method reveals the same sort of pattern, but it is possible to view it with the light microscope. The technique is dependent upon the use of one of the many types of pretreatment of the fixed chromosomes. Thereafter the staining takes place with the complex dye solution known after its originator Giemsa (G) (Fig. 2). 
C-banding : this technique reveals the constitutive (C) heterochromatin, a chromosomal part which is usually located adjacent to the centromeric regions. These regions are darkly stained, while the remaining parts of the chromosome arms are more or less negative. The differentiation of this technique does not allow the individual recognition of each chromosome (Fig. 3).

R-banding : reverse (R) bands can be achieved by the induction of a controlled heat treatment in a saline buffer before staining with Giemsa. The banding pattern is the reverse of that revealed by the $Q$ - and $G$ banding procedure. A variant of the technique makes use of a fluorescent dye: acridine orange. R-banding is useful if the telomeres are involved in aberrations (Fig. 4).

Prometaphase banding : with this method the number of visible bands on the differentially stained chromosomes is increased and therefore the resolution as well. the method is based on a synchronisation procedure allowing the harvest of an increased number of cells at the early stages of division. The banding methods applied afterwards do not really differ from the ones applied on metaphase chromosomes.

Prometaphase banding is necessary to confirm or exclude Mendelian disorders like the Langer-giedion syndrome and the Prader-Willi syndrome on chromosomes 8 and 15 respectively.

Furthermore this technique can be applied to determine very precisely the breakpoints in case of a structural abnormality (Fig. 5).

\section{Fragile Sites}

A fragile site is a specific chromosomal area with the following characteristics:

a. Unstained, variable in size and mostly enclosing both chromatids

b. Potentially present in all cells of an Individual

c. Dominantly inherited

d. Fragile, i.e. under appropriate in vitro conditions the fragility is demonstrated as chromatid breaks, chromosome breaks leading to deleted chromosomes and acentric fragments and triradials produced by chromatid breakage in previous division followed by non disjunction of the distal fragment.

The appropriate culture condition for most but not all fragile sites is the almost complete absence of folic acid in the culture medium. The same 
sites can be induced by the addition of antifolate drugs (methotrexate, FUdR or aminopterin) added to the culture medium.

\section{Fra(X) Studies}

Peripheral blood was phytohaemagglutinin (PHA) stimulated and the lymphocytes were grown in medium 199 with $5 \%$ fetal calf serum buffered with HEPES. The cells were cultured for 72 hours. G-banding was used for the identification of the $X$ chromosome. The percentage of fra $(X)$ positive cells was evaluated in a minimum of 100 cells. The person under investigation was considered to be fra $(X)$ positive if at least 2 cells showed a fragile site at $\mathrm{Xq27.}$

\section{Centre for Human Genetics, Leuven}

This thesis was done at the Centre for Human Genetics, of the University of Leuven (Belgilum).

My function as pedagogue in the staff of Clinical Genetics has two integrated objectives. One is of care and involves the evaluation of the developmental capacities of a child and to help parents how to optimally reach his individual potential. Behavioural and educational problems are in general more important than just the lower intellectual capacity of the child. Besides the answer to the question why the child has a psychomotor delay and disturbed behaviour, major attention is paid to the treatment possibilities and advice as to the upbringing of the child at home. Clinical practice focuses on the problems of the parents, and the educators as well. Therefore we always meet the parents and child at home and visit the school settings to inform teachers and educators.

Based on these experiences and longterm follow-up findings in these children with chromosomal syndromes, we became Interested by the role of chromosomes and their genes in cognitive and behavioural development. Therefore, we set up a multidisciplinary approach of children with different specific chromosomal syndromes and submitted them to extensive medical and psychological diagnostic evaluations.

Better knowledge and understanding of the psychopathology in chromosomal syndromes are of increasing importance in the early recognition and diagnosis and constitute an important adjunct in the decision to perform cytogenetical investigation in children with analogous clinical and behavioural abnormalities. 


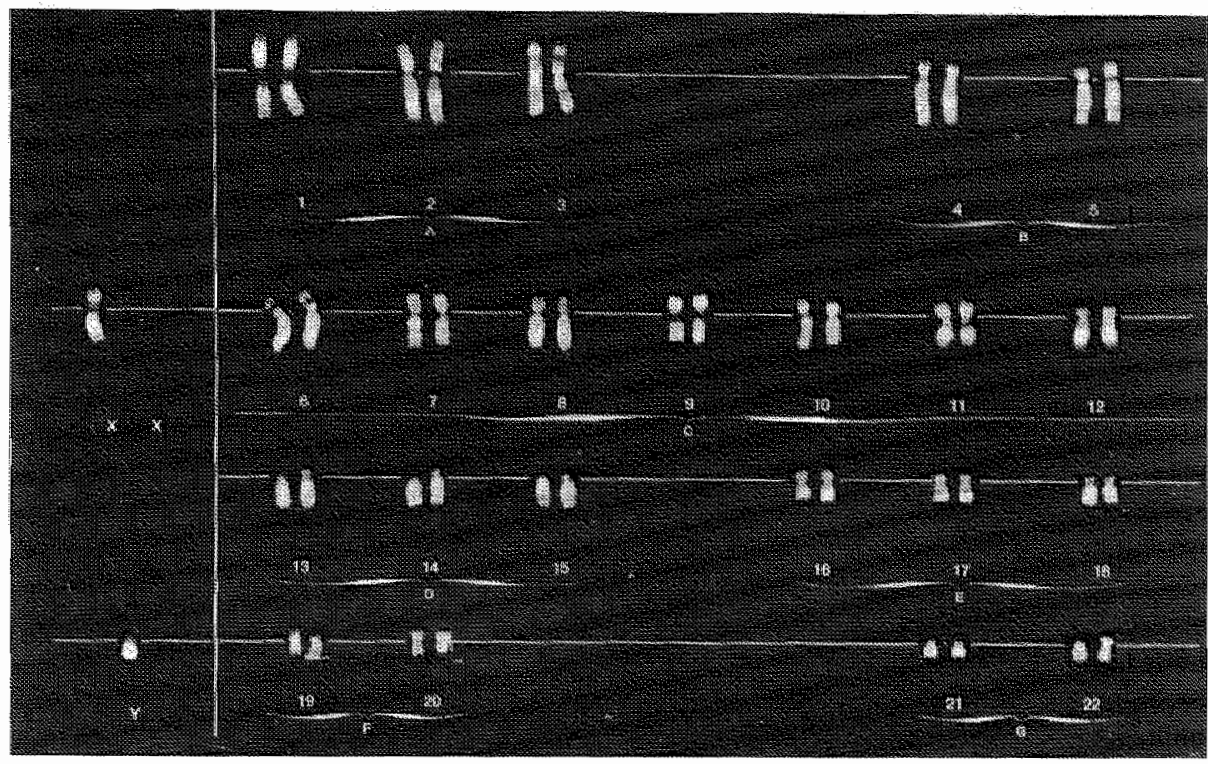

Fig. 1. Q-banding

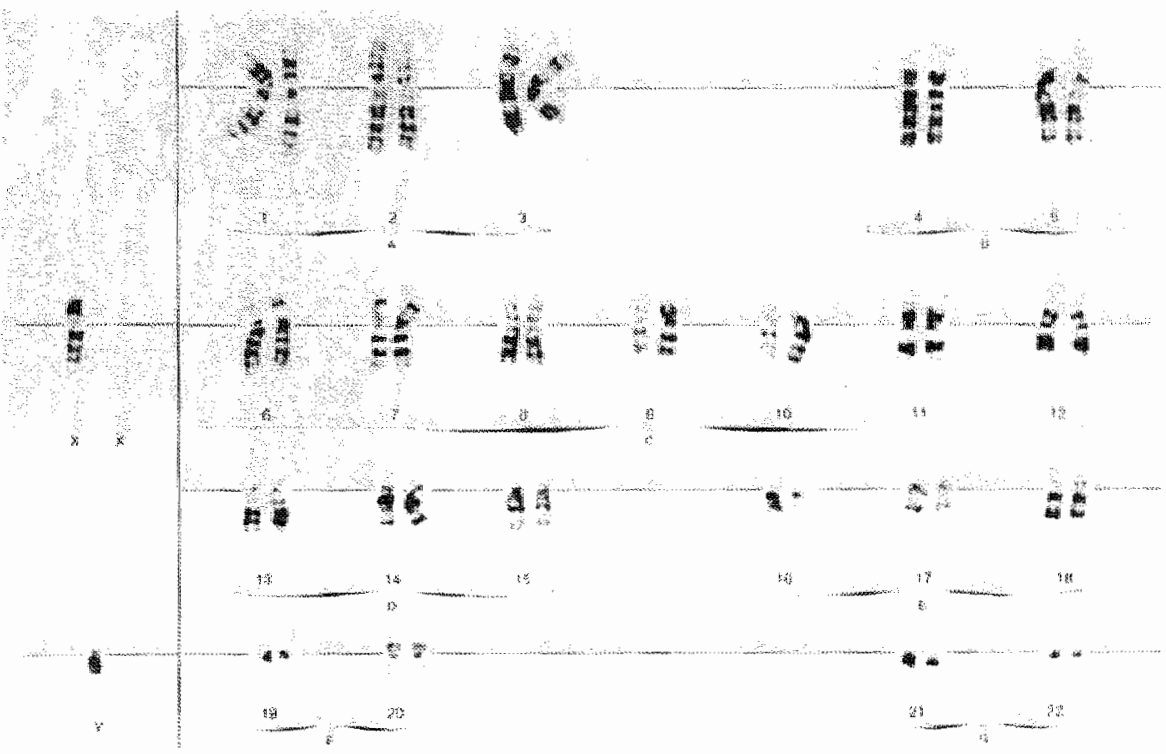

Fig. 2. G-banding 


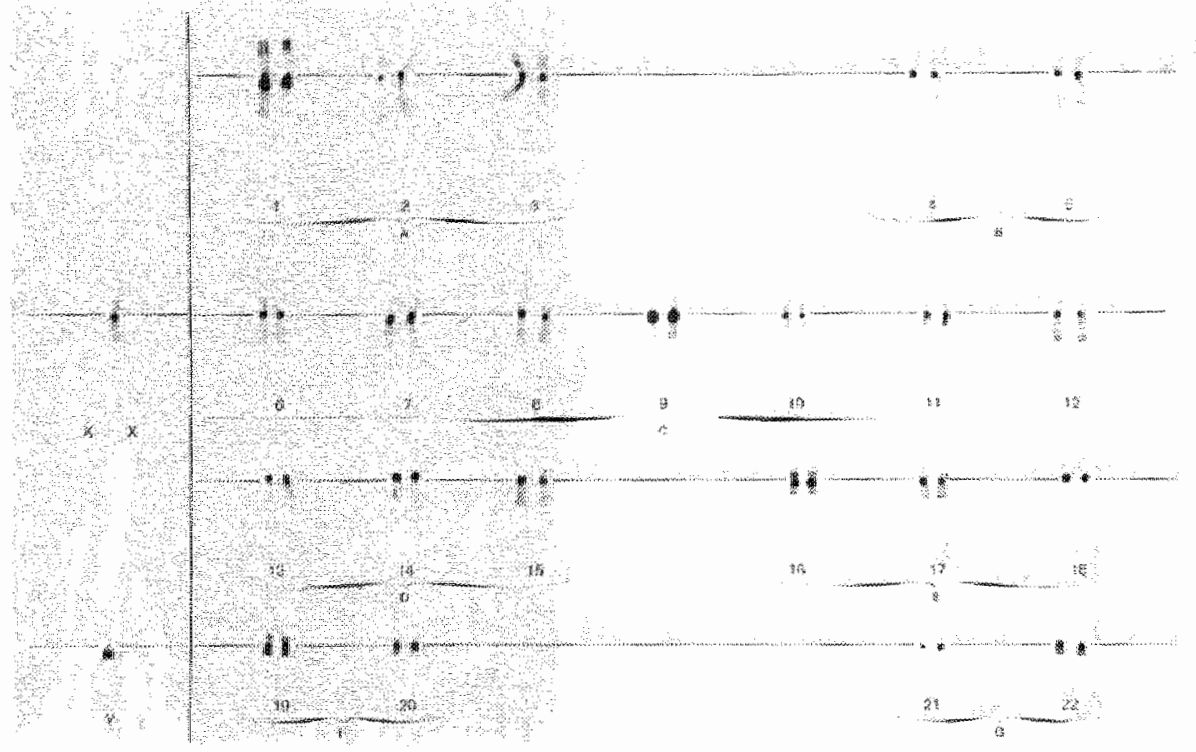

Fig. 3. C-banding

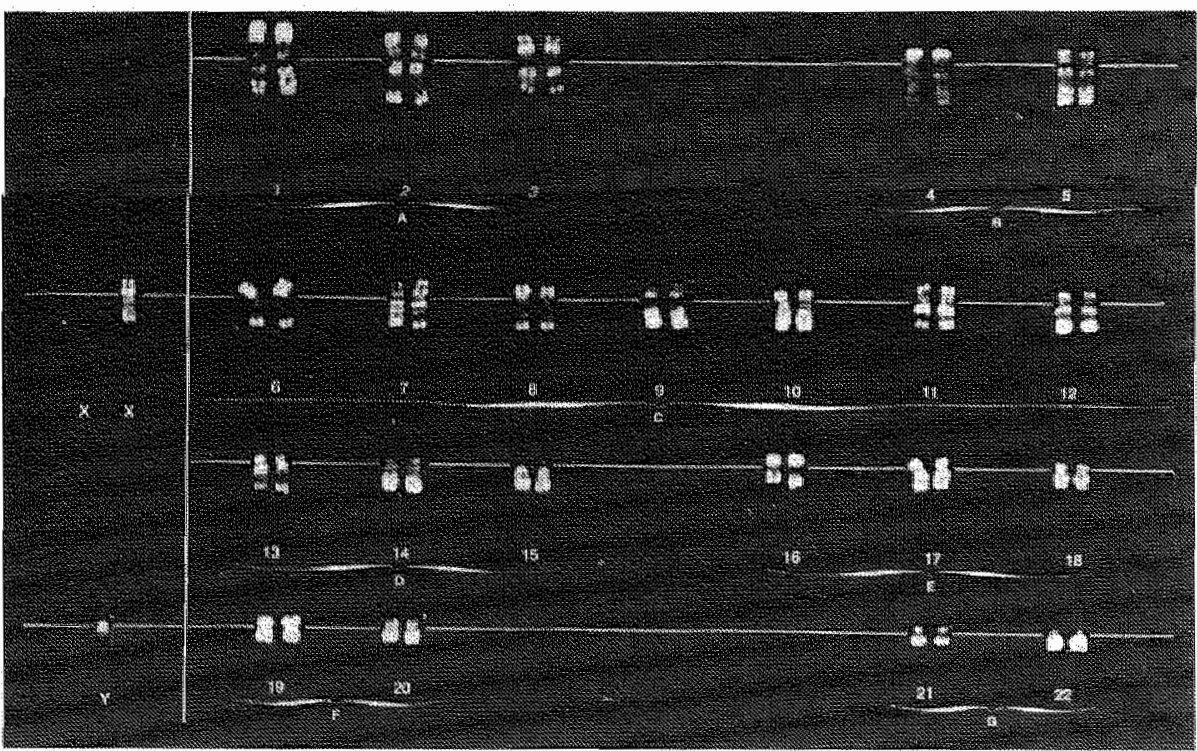

Fig. 4. R-banding 


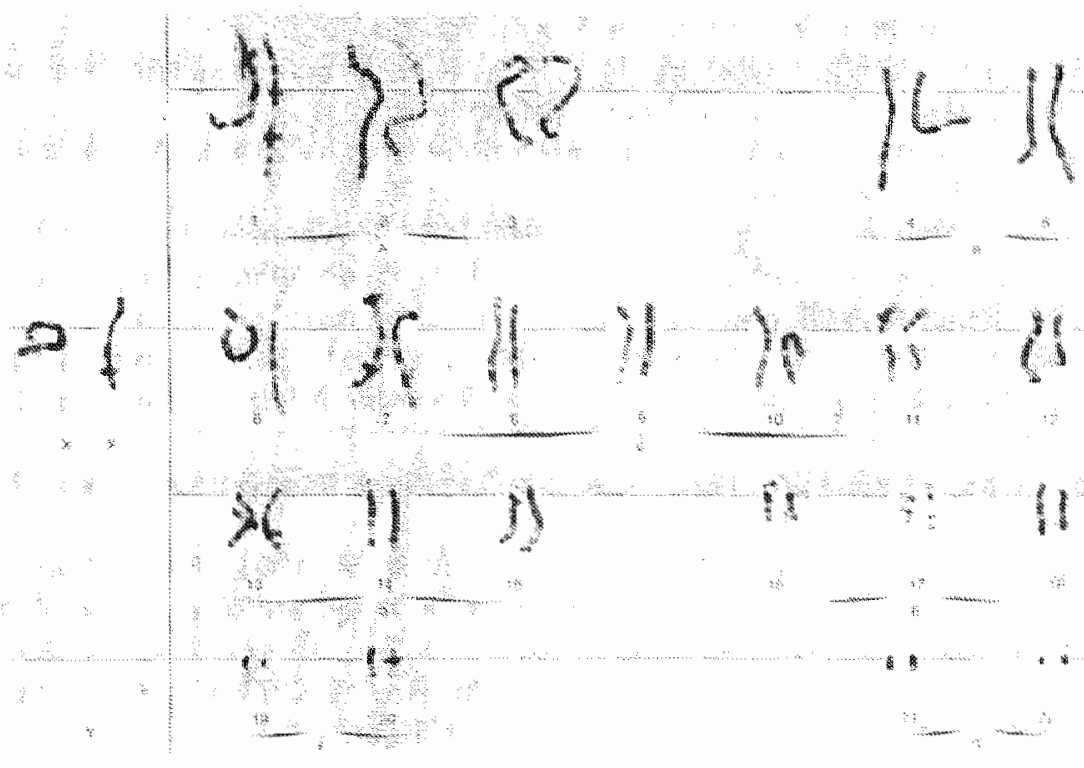

Fig. 5. Prometaphase

\section{References}

American Psychiatric Association. 1987. Diagnostic and Statistical Manual of Mental Disorders, 3rd edition, revised. Washington, DC, American Psychiatric Association.

Dumont J.J. 1985. Leerstoornissen. Diagnostiek en behandeling. 5 de geheel herzliene druk, Rotterdam, Lemmiscaat, pp. 13-141.

Dumont J.J.: Leerstoornissen. Rotterdam, Lemniscaat. 1971. 304 pp.

Hellinckx: Sociale Vaardigheid voor Geestelijk Gehandicapten. Rotterdam, Lemniscaat, $1973,237 \mathrm{pp}$.

Günzburg, H.C. 1977. Progress Assessment Chart of Social and Personal Development Manual (2 vols.). SEFA Publications Ltd., Birmingham.

Krajer D.W. 1978. Test en Schoolgebruik in de zwakzinnigenzorg. Amsterdam, Swets en Zeitlinger, $81 \mathrm{pp}$.

Sattler J.M. 1974. Assessment of Children's Intelligence. Philadelphia PA,

W.B. Saunders Co., pp. 127-148, 191-207, 302-320, 441.

Sattler J.M. 1988. Assessment of Children, 3rd ed. San Diego CA, J.M.

Sattler, pp. 245-292, 531-562. 
Schopler E., Reichler R.J. 1982. Geïndividualiseerd onderzoek en behandeling van kinderen met autisme en andere stoornissen. (vertaling door Th. Peeters). Nijmegen, Dekker en van de Veght.

Snijders, J.T., Snijders-Oomen, N. 1975. Niet-Verbale Intelligentieschaal, S.O.N. $21 / 2-7$. Groningen, Tjeenk-Willing.

Stinissen J. 1965. Terman-Merrill Intelligentieschaal-Vorm L-M. Katholieke Universiteit Leuven, Leuven.

Stinissen J., Van der Steene G. 1970. W.P.P.S.I. : Wechsler Preschool and Primary Scale of Intelligence. Handleiding bil de Vlaamse aanpassing. Lisse, Swets \& Zeitlinger.

Stinissen J., Willems P.J., Coetsier P., Hulsman W.L.L. 1970. Handleiding bij de nederlandstalige bewerking van de Wechsler Adult Intelligence scale (W.A.I.S.). Lisse, Swets en Zeitlinger.

Terman L.M., Merill M.A. 1973. The Stanfort-Binet Intelligence Scale, third revision. Boston, Higliton Mifflin.

Van Berckelaer-Onnes I.A., Harinck F.J. \& Smit M. 1981. Auti schaal ten behoeve van de onderkenning van vroegkinderlijk autisme. Lisse, Zwets \& Zeitlinger.

Van der Meulen B.F. \& Smrkovsky M. 1983. Bayley Ontwikkelingsschalen, BOS 2-30. Handleiding. Lisse, Swets \& Zeitlinger.

Van Haasen P. et al. 1985. Wechler Intelligence Scale for children - Revised (W.I.S.C.R.) nederlandstalige uitgave. Handleiding voor instructies en scoring. Lisse, Swets en Zeitlinger. 




\section{SUMMARY}

Up to now, research in mental retardation was devoted to the exact description of cytogenetic abnormalities and to the delineation of associated dysmorphic symptoms. However, almost no studies involved the kind of mental retardation, the changes with age, the behavioural characteristics and emotional development in mentally retarded patients, whereas overall it is clear that psychiatric disturbances are a major problem in these patients. The aim of the present thesis was to study the psychological profile and behavioural characteristics of children with specific chromosomal disorders.

Patients with the fra $(X)$ syndrome (Part I) were the first group submitted to extensive psycho-diagnostic examinations. Their results were compared to the psycho-diagnostic findings of a control group of mentally retarded. Most of the $\mathrm{fra}(X)$ boys were moderately mentally retarded. An important abservation was the negative correlation between age and level of intellectual functioning. This finding seems to indicate a decline in intelligence performances with age.

Hyperkinetic behaviour was twice more common in $\mathrm{fra}(\mathrm{X})$ boys compared to the control group, and autistic features were found in $30 \%$ of the fra( $X)$ males.

In the study of patients with sex-chromosomal disorders (Part IIA), followup data are reported of clinical observation, registration, psychometric testing and psychiatric evaluation in 8 young boys with $49, X \times X X Y$ syndrome, 4 males with $48, X X Y Y$ syndrome and 3 girls with $48, X X X X$ syndrome. An interesting finding was the specific effect of these different sex-chromosome aneuploidies on the individual physical and psychological development.

In the evaluation of children and adults with different autosomal syndromes (Part lib) we raised the question whether they presented a characteristic behavioural profile related to the chromosomal abnormality. We examined patients with trisomy 8 (mosaicism), ring chromosome 15 and the Prader-Willi syndrome. A distinct pattern of developmental abnormalities and a specific psychological profile was best illustrated by the study of 12 patients with Prader-Willi syndrome. They were all mildly to moderately mentally retarded with obvious behavioural problems, increasing with age.

The present results are the first of an ungoing project and call for further research. We are coming closer to understanding how the chromosomes affect the neurodevelopmental process that leads to behavior and 


\section{2}

cognition. Early diagnosis in a mentally retarded child, and precise knowledge on what can be expected, offers the child and his family the best opportunities for their well-fare. 


\section{SAMENVATTING}

In dit proefschrift worden de voornaamste onderzoeksgegevens betreffende psycho-dlagnostische evaluaties en gedragsobservaties bij kinderen met specifieke chromosomale afwijkingen en klinisch genetisch herkenbare syndromen besproken.

Jongens met het fra $(X)$ syndroom zijn de eerste groep patiënten die werden onderworpen aan een grondig psycho-diagnostisch onderzoek. De resultaten werden vergeleken met de gegevens van een controle groep van mentaall gehandicapten, op dezelfde wijze geëvalueerd en geobserveerd. De meerderheid van de door ons onderzocht fra $(X)$ jongens zijn matig mentaal geretardeerd met een grote spreiding van IQ's. Een opmerkelijke vaststelling was de negatieve correlatie tussen leeftijd en het niveau van intellectueel functioneren. Aandachtszwakte en hyperactief gedrag kwamen twee maal meer voor bij fra(X) jongens dan bij de controle groep, en was het meest uitgesproken op voorschoolse leeftijd. Autistiform gedrag werd beschreven bij $30 \%$ van de onderzochte $f r a(X)$ jongens. Deze onderzoeksgegevens bevestigen de stelling dat een duidelijk patroon van cognitieve ontwikkeling en gedragskarakteristieken fra( $X)$ jongens op prepubertaire leeftijd beter typeren dan het klinisch spectrum.

In een tweede deel worden de onderzoeksresultaten beschreven bij kinderen met uitzonderlijke $X$ - en $Y$-polysomieën. Jongens met het $49, X X X X Y$ syndroom zijn licht tot ernstig mentaal geretardeerd en hebben geen opvallende gedrags- of emotionele problemen. Meisjes met het $48, X X X X$ syndroom vertonen een sterk gelijkaardig beeld. Daar tegenover presteren jongens met een $48, X X Y Y$ syndroom mentaal beter maar tonen ernstige persoonlijkheidsdysfuncties en gedragsproblemen.

Tenslotte werden 3 groepen patiënten onderzocht met verschillende autosomale syndromen. De vraag of ook hier een typisch psychologisch profiel kan beschreven worden kon het best beantwoord worden met de resultaten van de studie van de patiënten met het Prader-Will syndroom. De meerderheid van hen is licht tot matig mentaal geretardeerd. Gedragsproblemen treden frequent op, en houden meestal verband met hun onverzadigbare eetlust. Vroege diagnose is dan ook van zeer groot belang voor hun fysisch en psychisch welzijn. Follow-up gegevens van meisjes met ring chromosoom 15 laten een ernstige groeiachterstand zien met typisch gezicht, en een lichte mentale retardatie en goede sociale integratie.

Het onderzoek bij jongens met een partiële of volledige trisomie van chromosoom 8 illustreert enerzijds de opvallende gelijkenis van het 
fenotype in beide condities, en anderzijds de verschillen qua cognitief functioneren en sociale aanpassing.

Dit geheel van onderzoeksgegevens bevestigt het belang van een vroege detectie en diagnosestelling bij een ontwikkelings-vertraagd kind. Hoe vroeger de juiste diagnose kan gesteld worden, hoe beter de ontwikkelingskansen voor het kind en zijn omgeving. 




\section{CURRICULUM VITAE}

De auteur van dit proefschrift werd geboren op 10 juli 1961 in Kinshasa (Zaiire). Zij behaalde haar diploma Hoger Secundair Onderwijs in 1979 (Mater-Dell Lyceum, Brussel).

Tijdens haar studies orthopedagogiek aan de Katholieke Universiteit Leuven beëindigde ze haar licentiaatsthesis "Psycho-fysisch onderzoek naar de oriëntatiegevoeligheid bij kinderen" in de afdeling Neurofyslologie, onder leiding van Prof. E. Vandenbussche. Zij behaalde haar licentlaatsdiploma met onderscheiding in 1984.

Vanaf 1985 is zij werkzaam in Leuven op het Centrum voor Menselijke Erfelijkheid (Directeur Prof. Dr. H. Van den Berghe), afdeling klinische genetica, onder leiding van Prof. Dr. J.P. Fryns. Haar functie als orthopedagoge binnen de genetische kliniek is veelzijdig en omvat naast de praktische dienstverlening aan en begeleiding van ouders met een mentaal gehandicapt kind, vooral onderzoekswerk naar de cognitieve ontwikkeling en gedragsprofielen van kinderen met specifieke chromosomale afwijkingen en klinisch genetisch herkenbare syndromen. 



\section{DANKWOORD}

Ik dank de Katholieke Universiteit Leuven, die mij gevormd heeft en haar rector Prof. Dr. Dillemans

en vice-rector Prof. Dr. H. Van den Berghe, directeur van het Centrum voor Menselijke Erfelijkheid, waar ik de kans gekregen heb mij waar te maken als orthopedagoge.

Bijzondere dank aan Prof. Dr. Fryns: reeds 6 jaar heb ik mogen genieten van zijn inspirerende invloed, enthoesiasme en overredingskracht. Zijn steun tijdens moeilijke momenten en zijn kritiek tijdens de gemakkelijke hebben mij steeds aangemoedigd om dit onderzoekswerk verder te zetten.

Prof. Geraedts will ik danken voor zijn belangstelling voor dit proefschrift. Dat hij tenslotte promotor van dit werk heeft willen zijn heb ik als eervol ervaren. I $\mathrm{k}$ ben ook ten zeerste verheugd geweest over het feit dat ook de patiënten van de Stichting Klinische Genetica Maastricht, op defzelfde wijze konden gevolgd en geëvallueerd worden dank zij de multidisciplinaire samenwerking met $C$. Schrander-Stumpel en K. Smulders-De Die, klinische geneticl.

Ik betuig ook mijn erkentelijkheid aan allen dit tot mijn vorming hebben bijgedragen: Prof. Van Walleghem, Prof. Hellinckx, Prof. Vandenbussche, Prof. Swinnen en in het bijzonder Prof. Dr. Pyck voor zijn niet aflatende interesse voor het onderwerp van dit proefschrift.

Mijn dank aan alle vroegere en huidige medewerkers van de afdeling Klinische Genetica, Leuven, voor hun voortdurende oprechte kommentaar tijdens de hele rit en in het bijzonder Mie-Jef Descheemaeker, Ann Swillen, Elly Pijkels en Maureen Holvoet voor hun concrete hulp tijdens drukke momenten.

Veel dank aan R. Logist en M. Van Leemputten: de snelheid en vriendellikkeld waarmee zilj begrip voor een bepaald probleem konden opbrengen, is nog steeds niet overtroffen door de efficiëntie van een personal computer, dank ook aan K. Rondou voor de (foto)grafische vormgeving.

Dank ook aan Dr. P. Curfs en A. Wiegers voor de vruchtbare samenwerking en de wederzijdse uitwisseling van informatie en gegevens.

Heel veel dank ben ik verschuldigd aan al de ouders en kinderen, en in het bijzonder de Prader-Willi Vereniging, die enthoesiast hebben deelgenomen aan het onderzoek, en voor het geduld waarmee ze mij, als bemoeizuchtige wijsneus, wisten op te vangen.

Ook aan de vroegbegeleidingsdiensten, scholen voor Bijzonder Onderwijs, en Medisch Pedagogische Instituten voor de vlotte 
samenwerking, vooral bij het verzamelen van follow-up gegevens en bij het organiseren van de hulp aan de diverse gezinnen.

Ik ben mijn ouders veel dank verschuldigd voor hun zeer stimulerende invioed en continue steun, en in het bijzonder mijn vader die in mij, reeds heel vroeg, interesse wist op te wekken voor (wetenschappelijk) onderzoek. Ook dank aan $\mathrm{F}$. Brak voor zijn adviezen bij de statistische verwerkingen.

Tenslotte wil ik zeker Luc niet vergeten, die het mij mogelijk maakte zoveel aandacht te besteden aan mijn werk, en bovendien mij feilloos wist op te vangen bij momenten van moedeloosheid.

En Lori, die in de loop van deze onderzoeksperiode is geboren en mij liet ervaren hoe fijn het is om gezonde kinderen te zien ontwikkelen en op te voeden.

Naast deze mensen zijn er zoveel anderen die op soms onvenwachte ogenblikken hebben bijgedragen aan het tot stand komen van dit proefschrift, aan al dezen hartelijk dank.

Leuven, 1991

Martine M.C. Borghgraef

Drukkerij M. \& L. Symons, Leuven 